\author{
UNIVERSIDADE DE SÃO PAULO \\ FACULDADE DE FILOSOFIA, LETRAS E CIÊNCIAS HUMANAS \\ DEPARTAMENTO DE GEOGRAFIA \\ PROGRAMA DE PÓS-GRADUAÇÃO EM GEOGRAFIA HUMANA
}

PABLO IBAÑEZ

Geopolítica e Inovação Tecnológica:

Uma análise da Subvenção Econômica e das

Políticas de Inovação para a Saúde

Versão Revisada

São Paulo

2011 


\author{
UNIVERSIDADE DE SÃO PAULO \\ FACULDADE DE FILOSOFIA, LETRAS E CIÊNCIAS HUMANAS \\ DEPARTAMENTO DE GEOGRAFIA \\ PROGRAMA DE PÓS-GRADUAÇÃO EM GEOGRAFIA HUMANA
}

\title{
Geopolítica e Inovação Tecnológica: \\ Uma análise da Subvenção Econômica e das Políticas de Inovação para a Saúde
}

Pablo Ibañez

Orientador: Wanderley Messias da Costa

Tese de Doutoramento

São Paulo

2011 


\section{Pablo Ibañez}

\section{Geopolítica e Inovação Tecnológica: \\ Uma análise da Subvenção Econômica e das Políticas de Inovação para a Saúde}

Tese apresentada ao Departamento de Geografia da Faculdade de Filosofia, Letras e Ciências Humanas da Universidade de São Paulo para a obtenção do título de Doutor em Geografia.

Versão Revisada. Exemplar original no CAPH da FFLCH.

Área de concentração: Geografia Humana

Orientador: Wanderley Messias da Costa

De acordo do Prof. Wanderley Messias da Costa.

São Paulo

2011 
IBANEZ, Pablo. Geopolítica e Inovação Tecnológica: Uma análise da Subvenção Econômica e das Políticas de Inovação para a Saúde, 2012. 245

f. Tese (Doutorado em Geografia) - Faculdade de Geografia, Letras e Ciências Humanas da Universidade de São Paulo, São Paulo. 
Pablo Ibanez

Geopolítica e Inovação Tecnológica: Uma análise da Subvenção Econômica e das Políticas de Inovação para a Saúde. Tese apresentada à Faculdade de Geografia, Letras e Ciências Humanas da Universidade de São Paulo para obtenção do título de Doutor em Geografia.

Área de concentração: Geografia Humana

Aprovado em:

\section{Banca Examinadora}

Prof.Dr.:

Instituição:

Assinatura:

Prof.Dr.:

Instituição:

Assinatura:

Prof.Dr.:

Instituição:

Assinatura:

Prof.Dr.:

Instituição:

Assinatura:

Prof.Dr.:

Instituição:

Assinatura: 
Plenitude talvez seja a antítese de um trabalho acadêmico. A sensação de que algo ficou negativo, de que aquela reflexão poderia ter sido escrita de forma mais clara ou mesmo de que aquela obra deveria estar referendada é constante e não há nada que remova essa lacuna. Até mesmo pelo fato da palavra falada ser levada pelo vento, mas da palavra escrita ficar impressa como tatuagem e, decerto, marcada para sempre em sua trajetória.

Todavia, há uma certeza: a de que a completude é dada ao saber que pessoas não faltaram e, muito menos, meios de solidariedade com meu trabalho. E isso, afirmo, me passa uma sensação positiva. Afirmo, também, que a sorte tem sido minha fiel companheira: colocou pessoas incomparáveis em minha vida.

Gostaria, em primeiro lugar, de agradecer ao meu orientador Wanderley Messias da Costa. Sua paciência e contribuição foram fundamentais para este trabalho. Tenho ainda que referendar seu total apoio quanto à mudança do tema.

Agradecimentos necessários também à Professora Ana Luiza D'Ávila Viana, que, com extrema generosidade, permitiu o uso de dados e reflexões de suas pesquisas, além de ter compartilhado comigo seus ensinamentos e visão política. Por essas e outras, sem dúvida, serei sempre grato.

Uma menção especial a João De Negri e Fernanda De Negri, que disponibilizaram todo o banco de dados dos Fundos Setoriais do IPEA e financiaram o trabalho de campo, além de ter aberto seu profundo conhecimento como pesquisadores.

A todo grupo de estatísticos do IPEA, em especial, a Patrick Franco Alves, pela paciência e prestatividade, e a Erick Costa Damasceno e Wesley de Jesus Silva, que foram fundamentais para a consolidação da base empírica aqui utilizada. Também gostaria de agradecer a Charles Bonani por ter compartilhado o trabalho das entrevistas.

A todas as empresas e seus representantes que nos receberam, contribuindo muito às análises aqui realizadas. 
À Capes, pelo apoio financeiro, sem o qual esta tese não seria possível.

Ao professor Marcio Cataia, pelas sugestões e companheirismo de longa data.

Ao professor Ricardo Mendes, pelas sugestões na qualificação e lições que vêm desde minha adolescência.

À professora Ana Clara Torres Ribeiro que me recebeu, mais uma vez, foi e sempre será fundamental na consolidação do meu caráter.

À professora Bertha Becker, que tive a oportunidade de encontrar em algumas ocasiões, seus ensinamentos foram estruturais para a tese.

À professora Mónica Arroyo, que muito contribuiu com suas sugestões.

À professora Maria Laura Silveira, sempre solícita.

Ao professor Fabio Contel, pelas conversas e orientações informais.

À professora Ana Cristina Fernandes.

Ao professor Antonio Carlos Robert de Moraes, pelas indicações e sugestões.

Ao professor Roberto Vermulm, pelas fundamentais orientações em um momento importante da tese.

Ao professor Glauco Arbix, por sua rigidez acadêmica e lições.

Ao professor Paulo Elias, in memoriam, por ter tido a oportunidade de compartilhar seus ensinamentos acadêmicos e suas lições de vida.

Sempre à professora Maria Adélia Aparecida de Souza, pelo incentivo e generosidade.

Agradecimentos necessários, agora, serão proferidos aos meus grandes amigos que muito contribuíram para a consolidação deste trabalho.

Em primeiro lugar, agradeço a Luis Leandro Ribeiro, que dedicou seu tempo à leitura e revisão desta tese.

À Mariana Vercesi Albuquerque, pela paciência e diversas sugestões.

À Marina Montenegro, que dividiu não só as angústias como também as contribuições.

A Hélio Farias, pelas conversas e ajuda fundamental. 
Aos colegas de orientação, Circe Dietz, Clarisse Coutinho e, em especial, Marcos Antonio Roseira, não tenho palavras para agradecer seu apoio e contribuição.

À Carolina Gabriel de Paula, pela ajuda em um momento crucial.

A um grupo de amigos, aliás, mais do que isso, verdadeiros irmãos, que me incentivaram em todo esse processo: Mario Lamas Ramalho, Lise Mielnik, Virna David Carvalho, Ricardo Alencar, Fabio Tozi, Samuel Frederico e Carin Carrer Gomes. E aos amigos que também fizeram parte do Grupo Geográfico: Mait Bertollo, Henderson Rocha. Flora Gal, Marina Moreto, Marina Castro de Almeida.

Aos grandes amigos, Gustavo Westmann e Sergio Gusmão Suchodolski, pela generosidade, parceria e hospedagem em Brasília.

A Hudson Pacifico e Elide Mendes, com quem tive a oportunidade de compartilhar um inspirador projeto de pesquisa. $E$ às ajudas fundamentais de Christiane Prescher Martins e Camila Aparecida Reginaldo da Silva.

Ao apoio irrestrito de Luiz Rossi, Adriana Innocencio de Oliveira, Matheus Almeida Fiusa e Miguel Lopes Cardoso Júnior.

Por fim, um agradecimento especial a minha família, não só pelo apoio moral, mas pelas contribuições.

A meu irmão, Adriano Nogueira Zerbini, que me fortaleceu e ajudou imensamente neste trabalho e fora dele.

À família HP e, in memoriam, com muita saudade, Idelci e Rubão.

À Mariana Ibañez Carvalho, minha fiel companheira e incentivadora. E André da Costa Carvalho, que muito contribuiu na elaboração das tabelas.

A Nelson Ibañez, que sempre me apoiou e, nesta tese, teve papel fundamental, contribuindo de forma decisiva para a mudança do tema.

À Mirian Inês Ibañez, pela dedicação, força e revisão. Sua contribuição foi decisiva.

À Fabíola Lana lozzi, pelas discussões, incentivos e reflexões. Sem dúvida, este trabalho só foi possível por seu companheirismo. 


\section{RESUMO}

IBANEZ, Pablo. Geopolítica e Inovação Tecnológica: Uma análise da Subvenção Econômica e das Políticas de Inovação para a Saúde, 2012. 245 f. Tese (Doutorado em Geografia) - Faculdade de Geografia, Letras e Ciências Humanas da Universidade de São Paulo, São Paulo.

A proliferação de políticas de incentivo à inovação tecnológica, no Brasil, nos últimos anos, tem tido destaque tanto nas discussões acadêmicas quanto na formulação dessas políticas. Ao mesmo tempo em que o Brasil melhorou sua condição econômica e diminuiu, em parte, a pobreza, também surgiu uma demanda por produtos e processos tecnologicamente mais avançados, como consequência tanto de uma transformação do padrão de consumo, como da própria atividade produtiva. A importação de conteúdo tecnológico, decorrente dessas mudanças, não só traz implicações negativas para a balança comercial, como também, do ponto de vista geopolítico, para nossa dependência em setores econômicos estratégicos no cenário mundial, hoje.

Com vistas à melhoria da capacidade de inovação tecnológica nas empresas brasileiras, o Estado tem promovido mudanças significativas como: o aumento do crédito para o financiamento de atividades para desenvolvimento tecnológico e inovativo; a criação de linhas de fomento específicas para a inovação em empresas privadas nas instituições antes voltadas exclusivamente para melhoria do sistema acadêmico nacional e a alteração da legislação para atender e dar maior eficiência aos objetivos da política nacional de inovação.

Nesse sentido, o objetivo da presente tese é entender a problemática geopolítica dos processos de transformações legais e institucionais em curso, no Brasil, a partir da Subvenção Econômica da Financiadora de Estudos e Projetos (FINEP) e das linhas de financiamento para inovação relacionadas à saúde.

Palavras-chave: geopolítica, inovação tecnológica, políticas públicas, subvenção econômica e saúde. 


\section{ABSTRACT}

IBANEZ, Pablo. Geopolítica e Inovação Tecnológica: Uma análise da Subvenção Econômica e das Políticas de Inovação para a Saúde, 2012. 245 f. Thesis (Doutorate in Geography) - Faculdade de Geografia, Letras e Ciências Humanas da Universidade de São Paulo, São Paulo.

The proliferation of incentive policies regarding technological innovation in Brazil has been drawing attention both in academic discussions and in the formulation of policies. While Brazil has improved its economic condition and reduced in part poverty, a demand for technologically more advanced products and processes has also emerged as a consequence from the transformation pattern but also from the economic activity itself. The importation of technological content, spawned from these changes, not only does it negatively affect our foreign trade accounts but also contributes, from a geopolitical view, for our dependence on strategic economic sectors in the world scenario today.

Aiming to improve the innovation capacity of Brazilian companies, the State has been promoting significant changes such as: growth of credit for the funding of innovative and technological development activities; creation of specific foster lines for innovation in private companies in institutions that before were focused on the betterment of the national academic system; and the change in the legislation to better meet the goals of the national innovation policy.

In this sense, the objective of the present thesis in to understand the geopolitical issues of the legal and institutional changes in course in Brazil, based on the Economic Subsides of the Financiadora de Estudos e Projetos (FINEP - Financier of Studies and Projects), and the funding lines for innovations in healthcare.

Key Words: geopolitics, technological innovation, public policies, economic subsides and healthcare. 
Introdução. 1

Parte I

Inovação Tecnológica e Geografia: Aprofundando Conceitos, Pensando a Geopolítica Brasileira

Capítulo 1

1 Aproximando a discussão teórica entre Geografia e inovação

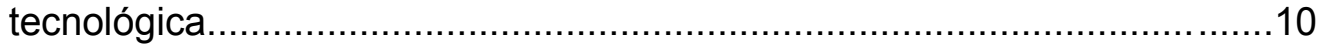

1.1. Resgate da discussão teórica sobre inovação tecnológica.................11

1.1.1. Sistema nacional de inovação: enfoque teórico............................17

1.1.2. O sistema nacional de inovação em saúde e o complexo industrial da saúde ......................................................................24

1.2 Geografia e inovação tecnológica................................................29

1.2.1 Pressupostos para uma abordagem geopolítica da inovação.......41

Capítulo 2

2 Geopolítica e inovação tecnológica: uma reflexão necessária....................54

2.1 Questões sobre a negligência da geopolítica....................................54

2.2. Perspectiva histórica da Geografia Política e da Geopolítica..............58

2.3. A retomada da Geopolítica : a inovação tecnológica no centro do debate.

Parte II

Subvenção Econômica e Políticas de Indução a Inovação em Saúde: aspectos da Geopolítica Brasileira

Capítulo 3

3 Fundamentos institucionais e legais da Geopolítica Brasileira: a FINEP e

a subvenção econômica. 96

3.1. Apontamentos sobre a economia institucional: à procura de um enfoque mais abrangente.

3.2. Aspectos do financiamento à inovação tecnológica: o papel da FINEP e os marcos legais.

3.2.1 Uma análise de subvenção econômica da FINEP 118

3.2.2 Uma análise exploratória dos quinze maiores desembolsos da Subvenção Econômica. 139

Capítulo 4

4 Políticas federais para ciência, tecnologia e inovação em saúde no Brasil: a saúde como área estratégica para a Geopolítica nacional

4.1. A política industrial tecnológica e de comércio exterior e a indústria farmacêutica 149

4.2. A inovação tecnológica no programa Mais Saúde: aprofundando as políticas de setoriais.

4.3 A saúde no PAC Inovação - Plano de Ação em Ciência, Tecnologia 
4.4. Cenário atual no Brasil e a política paulista de Parques Tecnológicos para saúde.

4.4.1 Políticas de inovação em saúde no Estado de São Paulo: os Parques Tecnológicos.......................................................191

4.4.1.1. Parque tecnológico de Ribeirão Preto................................197

4.4.1.2. Parque Tecnológico de São José do Rio Preto.....................201

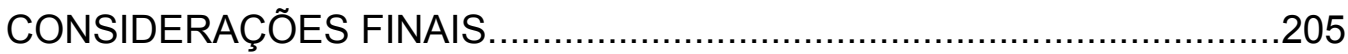

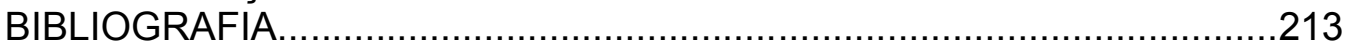

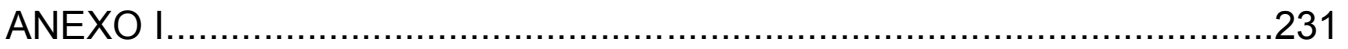




\section{ÍNDICE DE TABELAS, GRÁFICOS E QUADROS}

Tabela 1 Número de Empresas Cadastradas na Lei do Bem por Regiões por ano.

Tabela 2 Valores e Número de Projetos de Subvenção Econômica por ano...........................................................................119

Tabela 3 Empresas participantes da Subvenção Econômica da FINEP

e Dos Fundos Setoriais até 2008......................................130

Tabela 4 Empresas participantes da Subvenção Econômica da FINEP e das Modalidades BNDES.

Tabela 5 Empresas participantes da Subvenção Econômica da FINEP e da bolsa RHAE.

Tabela 6 Empresas participantes da Subvenção Econômica da FINEP e da Lei do Bem....................................................................136

Tabela 7 Perfil das Empresas Contratadas na Subvenção Econômica da FINEP por UF 2006, 2007 e 2008 - Média de Contratos, Pessoal com Terceiro Grau e Pós Graduação, Renda, Número de Patentes, Valor Exportado. 135

Tabela 8 Perfil das Empresas Contratadas na Subvenção Econômica FINEP por Porte - Número de Empresas, Média de Contratos por ano, de Pessoal Ocupado com Terceiro Grau e Pós Graduação, Número Médio de Patentes, Valor Médio Exportado $(R \$)$, Valor Finep $(R \$)$, Contrapartida Financeira $(R \$)$, Faturamento Médio (R\$) - 2006, 2007 e 2008. 136

Tabela 9 Comparação do Perfil das Empresas - RAIS, Fundos Setoriais e Subvenção Econômica FINEP - 2006, 2007, 2008................136

Tabela 10 Maiores financiamentos $(R \$)$ da Subvenção Econômica de, 20062007 e 2008...............................................................140

Tabela 11 Valores Desembolsados pela Finep às Empresas Alellyx e Canavialis, por ano.......................................................... 143

Tabela 12 Benefícios Reais dos Investimentos de P\&D por Setor, 2007. 157

Tabela 13 Balança Comercial de Medicamentos (Em US\$ Milhões) 2000 $-2007$.

Tabela 14 Balança Comercial de Farmoquímicos (Em US\$ Milhões) 2001 2007.

Tabela 15 Balança Comercial de Equipamentos, Aparelhos e Materiais Médicos, Hospitalares e Odontológicos (Em US\$ Milhões) 2001-2006.

Tabela 16 Dispêndio em P\&D no Brasil e em São Paulo. Gasto Total (Bilhões R\$), Gasto Total (\%) e Gastos no PIB Brasileiro

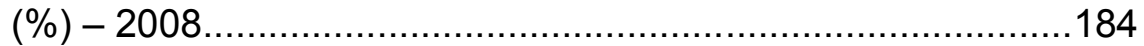

Tabela 17 Brasil: Dispêndio Nacional em Pesquisa e Desenvolvimento (P\&D) por Setores, em relação ao total de P\&D, 2000-2009

Tabela 18 Brasil : Dispêndio Nacional em Pesquisa e Desenvolvimento (P\&D) por Setores, em relação ao produto interno bruto (PIB), 2000-2009. 
Tabela 19 Exportação Brasileira dos Setores Industriais por Intensidade Tecnológica - 2000 a 2009 - US \$ milhões FOB 188

Tabela 20 Importação Brasileira dos Setores Industriais por Intensidade Tecnológica - 2000 a 2009 - US\$ milhões FOB. 188

Gráfico 1 Empresas Contratadas e Valor dos Contratos por Região na Subvenção Econômica........................................................121

Gráfico 2 Valor Contratado (\%) da Subvenção Econômica por Área Estratégica por Ano. 125

Gráfico 3 Empresas Contratadas e Valor dos Contratos por Porte das Empresas na Subvenção Econômica.....................................126

Gráfico 4 Contrapartida Financeira em relação ao Valor da Subvenção Econômica segundo Porte.................................................127

Gráfico 5 Distribuição das Empresas por Porte por Áreas Estratégicas na Subvenção Econômica 2007-2008.....................................127

Gráfico 6 Recursos do CT - Saúde (2003-2006) (em milhões) - Orçamento e Execução ....................................................................156

Gráfico 7 Recursos Disponibilizados para Execução do PAC,T\&I...........170

Gráfico 8 Participação dos Diferentes Grupos de Produtos, segundo Intensidade Tecnológica, nas Exportações Brasileiras

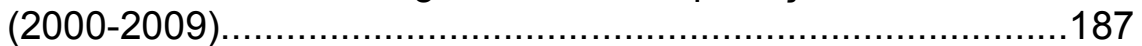

Gráfico 9 Participação dos Diferentes Grupos de Produtos, segundo Intensidade Tecnológica, nas Exportações Brasileiras (2000-2009). 187

Quadro 1 Os Padrões de Política Industrial de acordo com algumas Características................................................................153

Quadro 2 Diretrizes e Medidas propostas pelo Mais Saúde para o Complexo Industrial da Saúde. 164

Quadro 3 Eixos de Intervenção: diretrizes, medidas e metas prioritárias

Quadro 4 Instrumentos de Auxilio à Inovação Propostos pelo PAC,T\&I 2007-2010...................................................................173

Quadro 5 Plano de Ação 2007-2010 MCT - Prioridades Estratégicas e Linhas de Ação................................................................174

Quadro 6 Especificação dos Programas da Linha de Ação "Insumos para a Saúde", definida pelo PAC,T\&I 8007-2010 ……………….....176 


\section{INTRODUÇÃO}

Trabalhando com a questão da Guerra Fiscal no mestrado, um dos elementos que despontou como explicativo do fenômeno foi a falta de uma política industrial, sobretudo do governo central brasileiro, nos anos 90. $\mathrm{Na}$ ausência desse instrumento fundamental para a indução do desenvolvimento, uma competição acirrada pela atração de investimentos se alastrou pelo país, ficando conhecida como guerra fiscal ou guerra dos lugares ${ }^{1}$.

Com o fim da chamada Era FHC, entra em vigor o governo Lula que, logo em seu primeiro ano de mandato, lança a Política Industrial, Tecnológica e de Comércio Exterior (PITCE). Em seguida, é criada a Agência Brasileira de Desenvolvimento Industrial (ABDI), instituição de interface entre as empresas e o governo na promoção e efetivação das políticas governamentais. Uma série de leis passou a ser criada, ou mesmo modificada, para atender as demandas de uma política industrial e de inovação para o país.

Sendo a inovação um tema amplamente discutido no cenário internacional, assim como nas questões de modelos de desenvolvimento, entender as causas e desdobramentos das políticas de inovação brasileiras, nos últimos anos, torna-se fundamental pelas ciências humanas e, em particular, pela Geografia.

Dominada em grande parte pelo tema do desenvolvimento e do crescimento econômico, a inovação tem outras dimensões relevantes e o presente trabalho tem a intenção de desenvolvê-las; pensando, acima de tudo, a inovação como elemento fundamental da constituição de um projeto nacional para o Brasil. É obvio que as temáticas do crescimento econômico e do desenvolvimento têm sua importância. Quando Mokyr (2005:337) aponta para faceta da complementaridade entre o progresso tecnológico e o progresso

\footnotetext{
1 "Guerra fiscal é um termo utilizado para políticas de atração de investimentos via isenção fiscal. No Brasil, esse tema ganhou grande importância na década de 1990, período de acirramento do evento. Esse mecanismo suscitou opiniões divergentes, entre críticas e defesas, tendo como referências principais para a sua efetiva ocorrência as desigualdades regionais, o sistema tributário brasileiro, a estrutura federativa, a questão do emprego, as contas públicas, entre outras. Em que pese o aspecto polêmico, na realidade suas implicações se mostraram desastrosas" (IBANEZ, 2006:50).
} 
institucional como fontes do crescimento econômico, não podemos negar que há uma fundamental análise que perpassa as políticas de inovação.

Mas, pensar a inovação como elemento estratégico de uma Geopolítica brasileira voltada para a defesa de seus cidadãos e dos seus interesses econômicos, é central e, do ponto de vista financeiro, poderia criar melhores condições para o atual quadro da balança comercial brasileira - extremamente dependente da exportação de produtos de baixa densidade tecnológica e de importação de produtos de alta tecnologia -, assim como para a melhoria da condição de vida dos brasileiros ${ }^{2}$.

A saúde é um dos setores econômicos em que alguns dos apontamentos feitos acima ficam claros. Os avanços da medicina, em diversas patologias, são acelerados, o que tem permitido, com o uso de equipamentos sofisticados e fármacos, o aumento da sobrevida das pessoas, porém com custos altíssimos para quem financia os tratamentos, seja o setor privado, seja o setor público. Sob esse ponto de vista, a pesquisa desenvolvida pela professora Ana Luiza D'Ávila Viana ${ }^{3}$ pode servir de exemplo. Trata-se da análise da incorporação, pelo sistema de saúde brasileiro, de um equipamento para diagnóstico de câncer, a Tomografia Computadorizada por Emissão de Prótons (PET-CT). A grande virtude desse equipamento está na capacidade de diagnosticar precocemente alguns tipos de câncer, o que, por sua vez, evita tratamentos avançados, geralmente caros e penosos para os pacientes.

Como o equipamento é dependente de um radiofármaco, o FDG 18, que até o ano de 2002 tinha sua produção monopolizada pela União, esse tipo de diagnostico não era utilizado no Brasil. O motivo principal era que como só o governo produzia o radiofármaco, não havia garantias de seu suprimento e, portanto, poderia haver problemas na execução dos exames. Com a quebra do

\footnotetext{
${ }^{2}$ De Negri, Salerno e Castro (2005:11) afirmam que: "a remuneração média mensal do pessoal ocupado é $R \$ 1.254,64$ nas firmas que inovam e diferenciam produtos; $R \$ 749,02$ nas firmas especializadas em produtos padronizados; e $R \$ 431,15$ nas firmas que não diferenciam produtos e têm produtividade menor".

3"Tecnologia Diagnóstica para Doenças Crônico-Degenerativas: Estudo sobre o Modelo de Incorporação do Primeiro Aparelho de PEC-CT no Brasil - (2008/2010)". Instituição Financiadora: MCT/CNPq/ANS $N^{\circ}$ 25/2007. Departamento de Medicina Preventiva da Faculdade de Medicina da Universidade de São Paulo (DP/FM/USP). Coordenação: Profa. Dra. Ana Luiza D’Ávila Viana.
} 
monopólio da União, através da Emenda Constitucional 49, alguns hospitais e clínicas privados incorporaram o equipamento e, hoje, a ampliação do seu uso ocorre de maneira acelerada, já tendo entrado no rol de procedimentos do Sistema Único de Saúde (SUS).

O custo do exame é alto, porém esse não seria o ponto mais significativo para a discussão aqui proposta. Já o custo e o domínio das tecnologias tanto do equipamento em si quanto do acelerador cíclotron ${ }^{4}$ para a produção do radiofármaco, sim, configuram-se como elementos importantes da abordagem. O equipamento e o acelerador representam alto investimento e, basicamente, nenhuma peça ou parte da tecnologia é produzida internamente, ficando o país dependente de uma tecnologia eficaz contra uma doença que atinge milhões de pessoas pelo mundo. Esse exemplo é extremo, sobretudo porque falamos de um setor muito específico, o de equipamentos médicos de alto conteúdo tecnológico. Ainda, se observarmos as empresas que fabricam o PET-CT, nenhuma delas teve sua origem ligada ao setor médico-hospitalar e sim aos setores de eletrônicos e outros, como são os casos da Siemens e da General Electrics. O que retrata, em parte, a dependência desse setor em relação ás tecnologias importadas.

Outro exemplo interessante, mais amplo do ponto de vista das políticas de inovação, é dado pelo estudo realizado por Nelson $(2006)^{5}$. O autor realizou uma análise comparativa dos sistemas nacionais de inovação em três grupos de países: os com níveis mais elevados de renda, EUA, Japão, Alemanha, França, Itália e Reino Unido; os pequenos com renda muito alta e forte base de recursos na agricultura, Austrália, Canadá, Dinamarca e Suécia; e os com níveis de renda mais baixos, Argentina, Brasil, Coréia, Israel e Taiwan. Dentre várias questões, chama a atenção o fato dos países que tomaram decisões

\footnotetext{
${ }^{4}$ O PET-CT, até setembro de 2009, encontrava-se em operação em 32 estabelecimentos de saúde no país, com previsão de expansão. As empresas que o produzem no mundo são poucas, sendo as principais: a Siemens Medical Solutions, a GE Healthcare e a Philips Medical Systems. O custo do equipamento gira em torno de $R \$ 1,5$ milhões. Já o acelerador cíclotron, utilizado para a produção do FDG-18, tem sua tecnologia de produção e a produção em si dominadas por apenas seis países: Alemanha, Bélgica, Canadá, Estados Unidos, Japão e Rússia. Uma das instituições brasileiras, que adquiriu o acelerador, pagou o equivalente a de $\mathrm{R} \$ 9$ milhões pelo equipamento, fora os custos com instalação e manutenção.

${ }^{5}$ Apesar de o ano de publicação do livro ter sido 2006, o estudo que serviu de base para suas argumentações foi originalmente publicado em Industrial and Corporate Change, em 1992.
} 
conscientes para desenvolver e sustentar a força econômica em determinadas áreas, como a segurança nacional, apresentarem melhores resultados. Tratase de algo relevante porque, em quase todos os países, o setor de defesa aparece como indutor do sistema nacional de inovação, via atuação estatal, ainda que as diferenças entre eles sejam explicitas - no caso de Brasil e Argentina, as elites militares que governaram ambos os países, ao longo de anos, também foram responsáveis por avanços nessa área. Desse setor derivam ainda incrementos, segundo o mesmo autor, sobretudo em atividades espaciais, energia elétrica, telecomunicações e áreas civis de alta tecnologia. Em todos os casos, é evidente a participação do Estado na indução das inovações.

É exatamente nos apontamentos acima que reside a questão: como desenvolver um sistema nacional de inovação capaz de produzir tecnologias importantes para o bem-estar da população, assim como para as necessidades efetivas de uso do território brasileiro?

As perspectivas não apontam para um futuro fácil, nem sequer estamos trilhando um caminho exitoso, até o momento. Segundo Almeida (2009), os resultados da política industrial brasileira do governo Lula ainda não podem ser comprovados, ao contrário, pois após o lançamento da primeira política industrial, a PITCE, a balança comercial brasileira nos setores de alta e média tecnologia revelou resultados deficitários crescentes. Ou seja, ainda que definidas formas de incentivo ao setor produtivo, áreas de interesse nacional julgadas estratégicas e remodelagem/criação de instituições para dar maior eficiência às diretrizes da política industrial e tecnológica, os resultados esperados não foram alcançados: aumentamos nossas importações de produtos com alto componente tecnológico e continuamos dependentes da exportação de produtos primários para compor nosso saldo positivo.

Independente dos resultados não esperados da política, até porque as análises foram feitas no curto prazo, entendemos que deve haver continuidade dessas ações para que haja uma mudança nesse quadro. Portanto, a perspectiva do presente estudo é servir de instrumento de análise da consolidação e dos resultados das atuais políticas de inovação tecnológica do 
estado brasileiro, tendo em vista o fato de serem recentes e estarem inseridas em um contexto de extrema aceleração.

As conclusões, ainda que possíveis, parecem-nos um pouco precipitadas. Desdobramentos de políticas desse porte tendem a ser de médio e longo prazo, mas o acompanhamento das mudanças institucionais e dos próprios resultados das políticas é fundamental para propostas futuras e efetivação de uma política industrial e tecnológica de acordo com as reais necessidades explicitas no território brasileiro.

Como predomina, nos estudos, o prisma econômico, uma das inquietações que perpassou o trabalho foi realizar uma análise da inovação a partir de uma leitura geopolítica. Quando, no final da década de 1980, Becker (1988) propôs um resgate da Geopolítica com base no entendimento dos processos de reestruturação do Estado brasileiro, que apontavam para liberalização do mercado e privatizações, é inegável que uma relevante análise acerca da atuação estatal estava sendo traçada. Bertha (idem) reforça o papel que o Estado teve nesse processo, resultando, na época, em sua própria fragmentação e gestão privada do espaço nacional.

Nossa proposição está baseada em uma atualização desse 'resgate da Geopolítica', a partir afirmação da necessidade da atuação estatal nas políticas de inovação, fato que corrobora uma visão geopolítica, já que é baseada em estratégias voltadas à defesa de interesses nacionais, como a diminuição da dependência externa em setores fundamentais - como energia, defesa e comunicação -, e a garantia de acesso a tecnologias de saúde pela população brasileira. Por outro lado, não entendemos que é apenas o Estado que idealiza e concretiza políticas nessa área. Essas são resultado de amplos debates que contam com a participação de associações privadas, representantes de diversas universidades e institutos de pesquisa e sociedade civil organizada.

No Brasil, as Conferências Nacionais de Ciência, Tecnologia e Inovação são o exemplo mais claro dessa participação para além do governo. A consolidação das linhas de financiamento específicas à inovação, que se proliferaram nos últimos anos, é reflexo dos debates ocorridos nesse fórum, no 
qual em sua última edição, além da presença marcante de instituições governamentais como diversos ministérios e agências de fomento à inovação, tivemos a participação de diferentes segmentos representativos da sociedade como as associações empresariais, a Associação Brasileira de Organizações Não-governamentais, a União Nacional dos Estudantes, e a United Nations Educational, Scientific and Cultural Organizaion (UNESCO).

Nesse sentido, pensar a Geopolítica da inovação pressupõe uma aproximação com a noção sistêmica de inovação, porém com ênfase na atuação estatal, sobretudo no direcionamento das políticas de inovação, tendo em vista que até a década de oitenta as teorias de inovação eram dominadas por uma visão linear, resultado de um processo progressivo desde a pesquisa básica, passando pela pesquisa aplicada, pelo desenvolvimento e a fabricação do produto.

Lundvall (1992) é o primeiro a utilizar o termo sistema nacional de inovação. Nessa concepção, a inovação deixaria de ser vista como um processo apenas vinculado ao desenvolvimento de produto de competência particular das empresas e passaria a ser compreendida como um sistema composto pela interação de setores governamentais, universitários e industriais (GODIN, 2007). Assim, ganha relevância a atuação do Estado na indução da inovação, tendo em vista suas particularidades territoriais, políticas e sociais. $\mathrm{O}$ que corrobora nossa proposição analítica da inovação pelo prisma geopolítico.

Para a concatenação dessas discussões, dividimos a tese em duas partes. Na primeira parte, discutem-se os fundamentos teóricos que perpassam as principais temáticas envolvidas na tese. Assim, no primeiro capítulo uma revisão das teorias da inovação tecnológica é feita a partir dos clássicos e das leituras contemporâneas sobre o conceito de sistema nacional de inovação. Então, realiza-se uma aproximação da teoria geográfica à inovação. Em relação ao sistema de ações, dá-se a devida ênfase ao papel do Estado, aproximando, assim, nossa abordagem dos pressupostos do sistema nacional de inovação. E, ao final, procura-se revisar os estudos e escolas que estabelecem análises espaciais sobre a inovação tecnológica, tanto na Geografia quanto na Economia. 
No segundo capítulo, é feita uma revisão teórica sobre a Geografia Política e a Geopolítica. Inicia-se pontuando o relativo abandono da Geopolítica, nas análises geográficas, decorrente de sua participação na construção de políticas estatais imperialistas. Retomam-se os clássicos, desde Ratzel, até a inserção do pensamento geopolítico no Brasil, a partir da Escola Superior de Guerra. Em seguida, a ênfase é dada às abordagens mais recentes sobre essas teorias, como sua aproximação às teorias das relações internacionais e a escola anti-Geopolítica. Por fim, é feita uma proposta de resgate da Geopolítica com base, principalmente, nas reflexões de Bertha Becker (1988) e sua revisão a partir das recentes políticas de inovação do estado brasileiro.

$\mathrm{Na}$ segunda parte, procura-se estabelecer os nexos empíricos que sustentem uma abordagem geopolítica da inovação tecnológica. Assim, está divida em dois capítulos. O primeiro analisa o financiamento denominado de Subvenção Econômica da FINEP. Pontuam-se as principais transformações institucionais e legais relacionadas a essa modalidade de indução ao desenvolvimento tecnológico no Brasil e, em particular, à FINEP, responsável pela execução do financiamento em questão. Posteriormente, procura-se identificar a consolidação de áreas estratégicas a serem financiadas, o alcance territorial do financiamento, por regiões brasileiras, a alteração do porte das empresas contempladas, seu perfil e a relação dessas empresas com outros financiamentos federais. Finalmente, faz-se uma análise do trabalho de campo realizado com base nas quinze empresas que receberam os maiores financiamentos. É importante frisar que essa parte do trabalho se presta a uma análise mais qualitativa do financiamento, já que o número total de empresas contratadas inviabilizaria a realização de entrevistas em todas.

O último capítulo relaciona-se à análise específica de um setor considerado estratégico para a Geopolítica nacional: a saúde. Tendo em vista a participação desse setor na PITCE, observa-se o caso específico da cadeia produtiva relacionada à indústria farmacêutica e seus resultados no curto prazo. O foco, então, passa para a introdução de políticas de inovação em saúde em dois programas federais: o Mais Saúde e o Plano de Ação Para Ciência, Tecnologia e Inovação (PACT\&I). O último eixo de análise pontua a atual 
situação desfavorável da balança comercial brasileira em setores de alta intensidade tecnológica, tendo destaque às indústrias ligadas à saúde e a participação do Estado de São Paulo nos gastos em Pesquisa e Desenvolvimento (P\&D), no país. Dada essa importância, por fim, resgata-se a política estadual de inovação de parques tecnológicos, demonstrando, assim, a consolidação da inovação em saúde em diferentes esferas de governo. 


\section{Parte I}

\section{Inovação Tecnológica e Geografia: \\ Aprofundando Conceitos, Pensando a Geopolítica Brasileira}




\section{CAPÍTULO 1. Aproximando a discussão teórica entre Geografia e inovação tecnológica}

Discussões sobre o conceito de inovação têm sido cada vez mais constantes, hoje, não só entre intelectuais e empresários, como também nas esferas institucionais e de pesquisa do Governo Federal. A premissa de que o Brasil precisa dar passos largos em direção a práticas inovadoras vem sendo amplamente discutida, não ficando restrita apenas a seus aspectos empresariais, embora de suma importância, mas também aos aspectos ligados às instituições e possibilidades de financiamentos indutores dessa prática.

No atual período da globalização, práticas inovadoras aparecem como mecanismo sine qua non para manutenção da competitividade externa dos países, assim como para diminuir a ingerência e dependência externa, problemas penosos para países subdesenvolvidos. A área da saúde serve de exemplo nesse contexto, já que os produtos utilizados envolvem altos custos e a dependência tecnológica revela a necessidade urgente de aprofundar políticas mais eficazes e condizentes com nossa realidade sócio-territorial. Além disso, é uma das áreas que concentra maiores investimentos e possibilidades de incremento inovador, constituindo um relevante lócus de acumulação de capital e uma importante dimensão do bem-estar social.

A grande questão que se coloca é como realizar uma nova forma de desenvolvimento, que seja fiel aliada da inovação em países sem desempenho considerável nessa área, como o Brasil. Como subsídio para essa reflexão, nesta seção realizaremos um resgate dos principais pressupostos teóricos sobre esse tema.

Assim, neste capítulo procuramos adotar uma estrutura que permitisse colocar o leitor a par das principais reflexões sobre a inovação tecnológica, em geral, e da forma como os estudos espaciais sobre a inovação têm sido abordados. Em primeiro lugar, veremos algumas noções conceituais sobre inovação e sua evolução recente. A ênfase é claramente dada pelos estudos 
econômicos preocupados com o crescimento econômico e a consolidação dos sistemas nacionais de inovação. A partir daí, realizamos uma breve análise de como essas teorias têm sido tratadas especificamente na saúde, já que essa servirá, em parte, como base para os apontamentos empíricos que serão apresentados na segunda parte desta tese.

Em um segundo momento, revelamos como a inovação vem sendo estudada do ponto de vista geográfico e, a partir daí, procuramos pontuar nosso arcabouço teórico-metodológico sobre o espaço geográfico, enfatizando o papel do Estado nas políticas de inovação. Com essas análises, pretendemos dar subsídios para fortalecer os argumentos direcionados ao enfoque da inovação tecnológica como elemento da geopolítica nacional, reflexão que será feita no próximo capítulo.

\subsection{Resgate da discussão teórica sobre inovação tecnológica}

A teorização sobre a inovação tem como um dos seus principais contribuintes o economista Josef Schumpeter, que relacionou a geração e a difusão da inovação tecnológica, organizacional e produtiva ao dinamismo do crescimento e do desenvolvimento econômico no capitalismo.

De acordo com Schumpeter, a ideia de que a competição no capitalismo não se daria apenas pela concorrência simples de preço ressaltou a importância de os economistas analisarem melhor a concorrência através de novas mercadorias, novas tecnologias, novas fontes de oferta, novos tipos de organização, ou seja, aquela concorrência que comanda uma vantagem decisiva de custo ou qualidade e que atinge não a fímbria dos lucros e das produções das firmas existentes, mas suas fundações e suas próprias vidas (SCHUMPETER, 1984:114). Isso ilustra sua reflexão sobre o caráter evolutivo do capitalismo, que denominou de 'destruição criativa', conceito que permanece com grande força nas atuais discussões sobre o tema. 
Não cabe aqui aprofundar questões muito específicas como fez Nelson (2006:145), sobre a noção de equilíbrio ${ }^{6}$, a 'hipótese schumpeteriana' ou mesmo o argumento das 'ondas longas', todas elas amplamente discutidas; mas sim abordar apontamentos estruturais, como a que se refere não exatamente à crítica que Schumpeter (1984) faz a doutrina de que a conservação do capital é o principal objetivo da atividade empresarial, mas sim em um dos desdobramentos dessa reflexão, que seria de como a criação de departamentos de pesquisas dentro das firmas se torna fator fundamental para o desenvolvimento dos processos de inovação. Segundo Schumpeter :

[...] a primeira coisa que faz uma empresa moderna, logo que sente poder sustentá-lo (sic), é estabelecer um departamento de pesquisa no qual todos os membros sabem que seu pão de cada dia depende de seu êxito em inventar melhorias.

$(1984: 128)$

Hoje, em países avançados, a maior parte dos gastos com P\&D é realizada pelas empresas ${ }^{7}$, contando ou não com incentivos e políticas governamentais, e não diretamente pelo Estado, ao contrário do Brasil onde as inovações são feitas majoritariamente pelo Estado $^{8}$.

Aqui abrimos uma frente importante de reflexão: apesar daqueles países terem na empresa privada o grande lócus de desenvolvimento da inovação, neles o papel das políticas de Estado que viabilizam esse tipo de gasto foi fundamental e permeia toda a discussão sobre os caminhos que os demais devem seguir em direção a políticas mais efetivas nessa área.

\footnotetext{
${ }^{6}$ Os "economistas que têm estudado inovação tenderam a ignorar ou suprimir o mais consistente e elaborado argumento de Schumpeter sobre inovação - o fato de ela fundamentalmente envolver um desequilíbrio, fazendo com que a teoria convencional do equilíbrio não possa lidar com a inovação tecnológica e suas consequências" (idem).

${ }^{7}$ Segundo dados da OECD (2010) há uma variação entre os países, mas naqueles com sistemas de inovação avançados os gastos da iniciativa privada com P\&D são vultosos, a exemplo de Coréia do Sul e Japão, onde os percentuais desse item, em relação aos gastos gerais, chegam a $72,9 \%$ e $78,2 \%$, respectivamente.

${ }^{8}$ Uma discussão empírica mais aprofundada sobre esse tema, no Brasil, será realizada no capítulo 4.
} 
O próprio Schumpeter, ao final de sua obra, já revela elucubrações ligadas ao papel do Estado para a inovação. De acordo com Szmrecsányi (2002), o pensamento de Schumpeter foi sendo modificado ao longo de sua obra. Antes da década de 1940, ele estava focado no empresário inovador, mas , após sua publicação Business Cycles, de 1939, muda seu prisma para o processo de inovação propriamente dito e, no final de sua vida, com a publicação Economic Theory and Entrepreneurial History, em 1949,

abre-se para algumas novas perspectivas, raramente levadas em conta pelos divulgadores e seguidores de seu pensamento. Uma das mais interessantes é, sem dúvida, a inclusão do Estado no rol dos agentes da inovação tecnológica.

(idem: 202)

No estudo em questão, Schumpeter (1949:270) não aprofunda essa atuação do Estado, mas questiona, na França de Louis XIV, a relevância da corte e da burocracia para os comerciantes e industriais da época, o que, por sua vez, introduz, ainda que no formato de questionamento, a importância do Estado.

Essa relação entre inovação e as políticas de governo passa a ser cada vez mais abrangência no desenvolvimento teórico do tema. Até a década de 1960, a inovação era vista como um processo linear, isto é, resultado de estágios sucessivos de pesquisa básica, pesquisa aplicada, desenvolvimento, produção e difusão, e a discussão sobre as fontes mais importantes de inovação dividia-se entre a importância do avanço científico e a demanda por novas tecnologias (CASSIOLATO e LASTRES, 2007). Por conta dessa concepção, apenas as grandes empresas e os Estados eram vistos como potenciais agentes inovadores da economia, pois o processo linear de inovação demandava um intenso investimento de capital e um longo prazo para a obtenção dos resultados, obviamente complicados para uma empresa capitalista.

Entre as décadas de 1970 e 1980 surge uma nova teoria da inovação em contraposição à perspectiva linear do processo e demandante de grandes 
somas de capital e de tempo. Dois estudos empíricos trazem os fundamentos básicos para a nova teoria da inovação: o Projeto SAPPHO, desenvolvido pela Universidade de Sussex (Inglaterra); e o Yale Innovation Survey, realizado pela Universidade de Yale (EUA). Os principais resultados demonstraram a relevância de alguns elementos, a saber: a constituição de redes formais e informais, a partir das ligações das empresas com fontes externas de informação científica e tecnológica; a preocupação com as necessidades dos usuários; a acumulação de capacitações internas, como fator fundamental para a interação das empresas com fontes externas de informação e conhecimento; e a apropriação, pelas empresas, de conhecimentos gerados no âmbito da economia nacional (CASSIOLATO e LASTRES, 2005).

Com esses estudos, ficou latente a importância das fontes de informação externas às empresas, "em particular, as associadas, principalmente, aos fluxos de conhecimento entre agentes produtivos da mesma cadeia de produção e, em escala reduzida, à universidade" (idem:36). Evidenciou-se, ainda, que as cooperações entre as empresas dependem das políticas públicas direta ou indiretamente relacionadas à ciência e tecnologia (C\&T), com as devidas diferenças por área científica, setor de atividades e natureza das inovações.

No início da década de 1980, a Organization for Economic Co-operation and Development (OECD) formou um grupo ad hoc de assessoramento em C\&T, composto por: François Chesnay, Christopher Freeman, Keith Pavitt e Richard Nelson, entre outros. A partir daí, os estudos da OECD passaram a ser as principais referências na definição de uma nova teoria e de uma nova política da inovação.

Em 1980, o Technical Change and Economic Policy, lançado pela OECD, é visto como

primeiro documento de política de inovação elaborado por um organismo internacional a desafiar as interpretações macroeconômicas tradicionais para a crise dos anos 70 e que enfatizou o papel das novas tecnologias para sua eventual superação

(op. Cit::36) 
Nessa década, foi reconhecido o caráter sistêmico da inovação e que decisões estratégicas e tecnológicas são dependentes de fatores mais amplos (macroeconômicos, sociais, institucionais, políticos e financeiros), convergindo para a definição de sistema nacional de inovação, conceito que será mais bem aprofundado no próximo item. Além disso, a OECD afirma a importância da atuação do Estado na formação e no desenvolvimento do sistema nacional de inovação, considerando que o livre mercado não seria vantajoso para os países menos desenvolvidos.

Tendo como focos o conhecimento, o aprendizado e a interatividade (entre empresas e organizações), o conceito de inovação deixa de ser uma visão linear, como ocorreu até a década de 1970, sendo definido como um fenômeno sistêmico e interativo, caracterizado por diferentes tipos de cooperação entre atividades interligadas, compreendendo principalmente sua assimilação, uso e difusão (CASSIOLATO e LASTRES, 2005:37; 2007:154). Diversos pesquisadores passaram a utilizar esse conceito nos estudos sobre ciência, tecnologia e inovação (GODIN, 2007:5). Além disso, os novos modos de compreender os processos inovativos permitiram privilegiar a produção baseada na criatividade humana, que é um dado intangível do ponto de vista da contabilidade econômica, e a inovação e aprendizado são vistos, hoje, como elementos interativos com múltiplas origens.

Para Lundvall e Borrás (2005:617), em primeiro lugar, o conceito de sistema de inovação não pode ser entendido como uma teoria econômica, assim como a perspectiva neoclássica. O conceito seria o resultado da integração de perspectivas teóricas e empíricas baseadas em décadas de estudos. Então o que seria esse sistema de inovação? Em resumo, aponta para o fato de que a inovação não é apenas resultado da competência particular de uma empresa e sim da 'competência' da interação entre firmas, fornecedores, usuários, instituições de conhecimento e 'tomadores de decisão' (idem).

Cassiolato e Lastres (2007:154) afirmam que antes da própria existência do conceito, Freeman, em seu célebre artigo Technological infrastructure and international competitiveness (1982), já havia enfatizado o caráter sistêmico da 
inovação. Freeman (2003[1982]:3) aponta, em primeira instância, que os estudos sobre competitividade e tecnologia que existiam até aquela época apresentavam dois enfoques majoritários. O primeiro era relacionado às teorias tradicionais das vantagens comparativas, com base nos custos dos fatores; e o segundo apontava que a questão tecnológica poderia ser manipulada por políticas adequadas, tanto nacionais quanto no nível da empresa. Sua posição estaria vinculada mais ao segundo enfoque, procurando entender as influências da ciência e tecnologia na competitividade internacional e como essa estaria organizada e modificada ao longo do tempo. Freeman (idem: 17), analisando os casos da Alemanha e da Inglaterra, questiona o confinamento das explicações apenas em termos industriais. Em sua opinião, o governo também teria papel central, a exemplo dos financiamentos de pesquisa e educação, das medidas de promoção das estratégias industriais e das próprias instituições financeiras.

Porém, quem efetivamente utilizou o conceito de sistema nacional de inovação pela primeira vez foi Lundvall, em seu livro de 1992, National Systems of Innovation: Towards a Theory of Innovation and Interactive Learning (FREEMAN, 1995:5).

De acordo com Cassiolato e Lastres (2007:154), a análise do processo inovativo passa a se concentrar, então, nas estruturas subjacentes a tais conexões de uso e difusão, evidenciando, assim, a importância do conceito de sistema de inovação como meio de compreensão desse processo em um contexto mais amplo da economia, da cultura, da política, da sociedade e do território nacional. Isso confere maior importância para as especificidades nacionais, regionais e locais na geração, uso e difusão das inovações.

Com a amplificação do conceito, a inovação torna-se um dos principais componentes das estratégias de desenvolvimento dos países (não apenas das políticas de C\&T ou das políticas industriais) e as políticas relacionadas a esse tema passam a ser entendidas como políticas pensadas para o sistema nacional de inovação. 


\subsubsection{Sistema nacional de inovação: enfoque teórico}

No item anterior, realizamos uma pequena apreciação sobre a evolução das teorias sobre inovação tecnológica. Dos clássicos até os dias de hoje, a contribuição do conceito de sistema nacional de inovação tem sido muito difundida e serve de base para os mais importantes estudos sobre os temas relacionados ao desenvolvimento econômico. Nesta parte pretendemos dar maior ênfase a essa teorização, explicitando os pontos centrais de suas análises.

Iniciando a discussão, é fundamental referendar o esforço teórico feito por Freeman (1995). Para esse autor, a discussão de sistemas nacionais remonta ao economista alemão Friedrich List, ou seja, a um período muito anterior ao em que efetivamente essa discussão tomou força. Em suas reflexões, List revogava que políticas estatais poderiam acelerar, ou tornar possível, a industrialização e o desenvolvimento econômico. A grande interface de pensamento desse autor foi a questão tecnológica. Segundo List (1841, apud, Freeman, 1995:6), o estágio das nações seria resultado direto da acumulação de todas as descobertas, invenções, melhorias, aperfeiçoamentos e esforços das gerações anteriores. List, também, constatou uma interdependência entre a importação de tecnologias e o desenvolvimento técnico nacional. Sua ideia era a de que as nações deveriam aproveitar as tecnologias importadas para melhorá-las e desenvolvê-las. Por fim, ele colocou muita ênfase no papel do Estado em coordenar e adotar políticas de longo prazo para a indústria e a economia. Para Freeman (idem:8), List antecipou todo o debate contemporâneo sobre os sistemas nacionais de inovação.

De qualquer forma, foi apenas na década de 1990 que o termo sistema nacional de inovação passou a ser trabalhado. Conforme explicita Godin (2007:12), a visão de sistema nos documentos da OECD já vinha sendo utilizada, a exemplo do documento The Research System, de 1972, em que aparece a sugestão de que pesquisas científicas e tecnológicas, do ponto de vista institucional, não poderiam estar dissociadas dos contextos políticos, 
sociais, econômicos e culturais. O avanço dessas ideias culminou em uma visão sistêmica da inovação associada à importância dos contextos nacionais, os quais, por sua vez, embasaram a formulação do conceito de 'sistema nacional de inovação', proposto por Lundvall (1992) e adotado pelos documentos da OECD a partir de $1990^{9}$.

O propósito primordial desse conceito era servir de base para a elaboração de novas políticas voltadas para a inovação e de afirmar a importância do Estado como interventor do processo de inovação. O documento referido inicia o texto enfatizando que a inovação é um processo interativo e que o sistema nacional de inovação tem papel central no desenvolvimento dos países (LUNDVALL e BORRÁS, 2005). Uma sintética definição do conceito é dada por Godin (2007:5):

The National Innovation System framework suggest that the research system's ultimate goal is innovation and that the system is part of a larger system composed of sectors like government, university and industry and their environment. The framework also emphasized the relationships between the components or sectors as the 'cause' explaining the performance of innovation systems.

Esse apontamento torna-se estrutural, sobretudo, por fazer uma contraposição às teses que foram lançadas durante o período da globalização como, por exemplo, da tendência ao 'tecnoglobalismo'. Para Cassiolato e Lastres (2003) essa ideia estaria relacionada ao fato de que a geração de tecnologias dar-se-ia de forma global, com o local não apresentando importância particular. Assim, a noção de sistemas nacionais de inovação veio a reforçar a relevância dos territórios nacionais e de seus processos históricos, políticos e sociais e busca a compreensão das mudanças técnicas e das trajetórias históricas de desenvolvimento dos países (CASSIOLATO e LASTRES, 2005:37).

\footnotetext{
9 "It was to Lundvall - nominated deputy director of the OCDE Directorate for Science, Technology and Industry (DSTI) in 1992 (until 1995) - that the OCDE Secretariat entrusted its program on National Innovation Systems" (idem).
} 
Jasanoff (2002) também estabelece uma interessante abordagem sobre o papel das políticas nacionais em relação à tecnologia. Partindo da ideia de modernidade e progresso, a autora demonstra uma preocupação que os Estados devem ter em relação aos avanços e à adoção desenfreada de novas tecnologias. A questão central não é a ideia em si de sistema nacional de inovação, mas sim as reflexões estruturais quanto à 'soberania' do progresso como forma de melhoria da vida das pessoas, e como os governos devem pensar nas suas próprias necessidades. Entre os exemplos utilizados no estudo, podemos citar a Revolução Verde e sua aplicação na Índia. Neste caso, mesmo com a 'importação' de sistemas agrícolas eficientes, afinal apresentava resultados em produtividade, a erradicação da fome, que era o principal objetivo do programa, não ocorreu e a tecnologia acabou por fortalecer grandes produtores, assim como causar problemas ambientais, pelo uso de substâncias químicas (idem).

Esse exemplo supracitado reforça o cuidado em relação à adoção de tecnologias a qualquer custo e o teor da intervenção estatal nesses casos. "O que muda ao longo do capitalismo é a natureza da intervenção e as maneiras pelas quais ela se apresenta" (CASSIOLATO e LASTRES, 2005:42). De maneira mais ampla, a história nos mostra que o Estado tem o papel de maior importância: como agente estruturante de novas forças produtivas; como agente orientador da difusão dessas forças na economia e na sociedade; como coordenador das políticas descentralizadas - no âmbito de um projeto de longo prazo para o país (idem). Porém, no caso do desenvolvimento tecnológico, esses autores apontam pelo menos três características principais da importância da intervenção do estatal:

1. Orientação na educação básica e nos níveis de pesquisa, por conta de mudanças nos processos de concorrência internacional;

2. Administração de problemas de instabilidade econômica e financeira (estabilidade monetária, taxas de câmbio, de juros e confiança nos sistemas bancário e de crédito);

3. Realizar regulação e desregulamentação por conta de mudanças de paradigma tecnológico. 
Dadas essas características processuais, Cassiolato e Lastres (2007) evidenciam que há necessidade de elaboração de um instrumental analítico e normativo mais amplo e complexo, em relação àquele oferecido pela teoria econômica tradicional, para dar conta da nova realidade da inovação e do desenvolvimento. Afinal, são observadas limitações nas análises quantitativas baseadas em modelos abstratos de eficiência tecnológica ou das políticas nessa área, o que, por sua vez, corrobora as ideias de Lundvall (1992) e Freeman (1995) sobre a necessidade de desenvolver um método com raciocínio histórico, para analisar as questões inerentes à inovação em diferentes contextos.

Nesse sentido, o conceito de sistema nacional de inovação permite que as políticas públicas adotem uma perspectiva mais condizente às potencialidades de cada nação. No caso de países menos desenvolvidos, os processos tecnológicos podem ter foco em inovações nas pequenas e médias empresas, bem como nas empresas tradicionais. Isso representa um enorme avanço, pois a política pública desses países não precisa, necessariamente, estar baseada em tecnologias extremamente avançadas mas a partir do foco de que

a inovação não se restringe a processos de mudanças radicais na fronteira tecnológica, realizados quase que exclusivamente por grandes empresas através de seus esforços de pesquisa e desenvolvimento (P\&D). (...) a inovação se estende para além das atividades formais de P\&D e inclui novas formas de produzir bens e serviços (...)

(CASSIOLATO e LASTRES, 2005:38)

Ou seja, não é a adoção ou cópia de um modelo definido que pode trazer resultados. Há diferentes modelos estabelecidos por países mais pobres que exemplificam posturas de atuação que deram certo. Freeman (1995:13), quando realiza a análise comparativa entre os países do Leste Asiático e da Latino América, enfatiza duas questões centrais dos modelos: no primeiro grupo, a importação de tecnologia foi combinada com transformações, com tecnologias locais, das mesmas, e o desenvolvimento de forte infraestrutura de C\&T com interações crescentes com o setor industrial; já no segundo, o 
processo privilegiou mais a importação pura de tecnologia, sem respectiva transferência tecnológica e com infraestrutura de C\&T fraca, sem interação com o setor produtivo. Essas diferenças, hoje, podem ser vistas no desenvolvimento tecnológico dos países em questão como ressaltado no item anterior sobre a composição dos gastos em P\&D no Japão e na Coréia do Sul.

Este último país, em relação à tecnologia, é muito emblemático. Kim e Nelson (2005:13) relembram que o mesmo exportava, em 1960, apenas US\$ 40 milhões, passando para US\$ 125 milhões, em 1995. O crescimento, realmente significativo, soma-se ao fato da Coréia do Sul ter passado, nesse mesmo período, de exportador de tecidos, roupas, brinquedos, perucas, ou seja, produtos intensivos em trabalho, para de computadores, semicondutores, circuitos de memória, videocassetes, sistemas eletrônicos de computação, automóveis, instalações, entre outros intensivos em tecnologia. Para Stiglitz (1996:151), essas transformações foram resultado de uma combinação de fatores como a elevada poupança interna interagindo com uma acumulação de capital humano em um ambiente de mercado estável, com base em clara intervenção estatal, e transferência tecnológica.

Não só a Coréia do Sul, mas também os demais tigres asiáticos tiveram a capacidade de utilizar suas políticas no sentido de promoção do desenvolvimento industrial e tecnológico "integrando-as (...) a outras intervenções de inventivo e de mercado de fatores, e impondo exigências aos beneficiários em termos de desempenho competitivo em mercados exportadores" (LALL, 2005:45). O acesso às tecnologias estrangeiras, como forma de aprofundamento tecnológico, foi fundamental nesse processo, assim como a combinação de intervenções no comércio exterior, a exemplo de restrições quantitativas, tarifas, aquisições e uma série de medidas administrativas para promover determinados ramos industriais (idem: 62).

O caso ilustrado anteriormente revela que políticas de inovação devem captar as especificidades dos diferentes contextos nacionais e locais dos sistemas de inovação e a necessidade de maior conhecimento que as empresas e seus funcionários requerem para poder interpretar a informação 
advinda de fontes internas e externas de cooperação que viabilizem com as próprias empresas e a sua capacidade de inovar.

Ainda em relação aos modelos, agências internacionais, como a OECD, sempre propõem alternativas para o desenvolvimento do sistema nacional de inovação. Ao mesmo tempo, tais agências ignoram a influência dos diferentes contextos macroeconômicos e nacionais para as políticas econômicas e de inovação e enfatizam as agências locais e o capital social local, diminuindo a importância do poder do governo nacional e valorizando o papel das instituições locais e de agentes do terceiro setor (especialmente as ONGs). Nas palavras de Cassiolato e Lastres (2005:41):

\begin{abstract}
Além do possível questionamento da falta de legitimidade dessas organizações, deve-se recordar que, na abordagem de sistemas de inovação, está explícita a importância da sua dimensão nacional. Assim - e de acordo com a abordagem apresentada aqui - a efetividade das políticas locais será reforçada com sua articulação à estratégia nacional e até supranacional. Mostra-se necessária uma coordenação dos diferentes níveis (desde o local, ao nacional e internacional) e tipos de políticas, assim como agências intervenientes - o que demanda uma forma de ação que só pode ser realizada na instância mais elevada do governo.
\end{abstract}

Como um contraponto a essas 'intervenções', as novas políticas voltadas para a inovação e o próprio sistema nacional de inovação são, hoje, valorizados pelos Estados que estão retomando o debate em torno do desenvolvimento, como resposta às concepções neoliberais que permearam as políticas nacionais e internacionais desde a década de 1970. A visão neoschumpeteriana que embasa a nova teoria da inovação, que será melhor analisada no capítulo 4, contribui com a crítica à teoria econômica neoclássica e ao neoliberalismo, na medida em que reafirma o papel estratégico do Estado como agente que incentiva a inovação e o desenvolvimento, e a importância dos diferentes contextos nacionais para a inovação, assim como, seus processos históricos distintos. 
Nelson (2006:428), apesar de não concordar plenamente com essa visão ${ }^{10}$ do papel do Estado, aponta que a redução do crescimento nos países desenvolvidos, a partir da década de 1970, o aumento da importância do Japão como potência econômica e tecnológica, a sofisticação técnica da Coréia do Sul e de outros países de industrialização recente em setores antigamente restritos a poucos e ricos países, contribuem para que as discussões sobre os processos de inovação ressaltem o componente nacionalista.

Existe claramente um novo espírito que pode ser chamado de 'tecnonacionalismo' no ar, combinando uma forte crença de que as aptidões tecnológicas de firmas nacionais são uma fonte-chave para o desempenho competitivo com a crença de que essas aptidões são em certo sentido de caráter nacional, e podem ser constituídas através de uma ação nacional.

(idem)

A despeito dessa visão mais global da inovação dada por Nelson, a retomada do papel do Estado, juntamente com a valorização dos contextos nacionais e dos processos históricos, a partir de uma visão mais ampla sobre inovação e sobre o próprio conceito de desenvolvimento, aponta para que a inovação dê o tom das políticas de desenvolvimento no contexto atual, marcado pela crítica às políticas neoliberais dos anos 1990, apreciação que faremos no item 1.2 .

Em função da base empírica do trabalho ser a subvenção econômica e das políticas de indução à inovação em saúde, não realizaremos a análise de questões relativas ao desenvolvimento das políticas nacionais do sistema de

${ }^{10} \mathrm{O}$ autor, na verdade, questiona o conceito de sistema nacional de inovação. Se observado o $P \& D$ da indústria farmacêutica norte-americana em relação ao da aeronáutica, a conclusão é de que seus enfoques são muito distintos. Outros exemplos também são citados. Em sua opinião, os sistemas de inovação tenderão a ser setorialmente específicos. Por outro lado, o desenvolvimento das indústrias ligadas à tecnologia demonstra uma complexidade de fatores e tende a tornar as fronteiras mais 'porosas', tornando aspectos ligados à tecnologia mais internacionalizados (idem:459). Todavia, vale lembrar que a inovação não trata apenas de processos extremamente avançados e de empresas multinacionais que contam com grandes investimentos em P\&D. Países atrasados do ponto de vista do desenvolvimento tecnológico não podem ficar completamente à mercê da inovação promovida pelas grandes firmas, tendo que constituir um diversificado sistema de inovação, com financiamentos específicos e setores estratégicos. 
inovação brasileiro neste momento, e sim na segunda parte da presente tese. Porém, a relevância das atividades econômicas ligadas às cadeias produtivas da saúde demonstra que elas mesmas acabam por conformar um sistema nacional de inovação, assim como de ser um elemento fundamental da geopolítica brasileira. Portanto, a partir desse ponto, faremos uma breve apreciação teórica sobre o sistema nacional de inovação em saúde, que servirá não só para ampliar as discussões sobre sistemas de inovação, como, também, subsidiará as reflexões empíricas da segunda parte da tese.

\subsubsection{O Sistema nacional de inovação em saúde e o complexo industrial da saúde}

Basicamente, o que pretendemos agora é formular uma apreciação sobre um setor específico, que é capaz de integrar a discussão teórica e empírica a uma análise da política nacional de inovação, a saber: a saúde vista como setor estratégico do desenvolvimento nacional e, também, elemento central da geopolítica nacional, que pretendemos enfatizar no quarto capítulo.

Todos os segmentos econômicos ligados à saúde apresentam especificidades relevantes no âmbito do sistema nacional de inovação, já que compartilham um alto grau de inovação e, por isso, representam um elevado dinamismo em termos de taxa de crescimento e de competitividade, assim como lidam com o mais importante bem de um país, a saúde de sua população. E essa dupla relação nos parece extremamente profícua para pensá-la sob o prisma da geopolítica, afinal é claramente uma defesa dos cidadãos e, por outro lado, defesa da capacidade produtiva nacional como fundamento da diminuição da dependência externa em um setor estratégico.

Para Viana e Elias (2007:1766) a noção da saúde como direito, bem econômico e espaço de acumulação capital nos remete a três elementos fundamentais na área da saúde nos últimos sessenta anos: a desmercantilização do acesso; a mercantilização da oferta; e a constituição do 
complexo industrial da saúde. Em relação ao primeiro elemento, os autores o apontam como resultado do entendimento da saúde como direito, consolidado, com maior ênfase, após a Segunda Guerra Mundial na Europa a partir da consolidação dos grandes sistemas nacionais de saúde financiados por impostos públicos. Já o segundo, seria o oposto com a mercantilização da oferta que se inicia com o assalariamento dos profissionais de saúde e passa pela conformação de operadoras de planos e seguros de saúde. Por fim, a consolidação das grandes indústrias produtoras de materiais, fármacos e equipamentos na ponta dos processos tecnológicos, sendo algumas delas a própria base da terceira revolução tecnológica, caracterizada pela biotecnologia e tecnologias da informação e comunicação (TIC).

No que diz respeito a esse terceiro elemento, a discussão da saúde como fundamento econômico estratégico se deu nos EUA, na década de 1950 (ANDREAZZI e KORNIS, 2008:1411). Na visão desses autores, o aumento do custo unitário da atenção médica e a rapidez da incorporação e obsolescência de novas tecnologias, nessa mesma década, nos EUA, apontavam para uma revisão de suas consequências para a dinâmica de acumulação em saúde. 0 lucro das empresas e os gastos familiares, que nesse setor operavam, sofriam interferências difíceis de serem apreendidas, incitando, assim, um debate mais aprofundado na saúde. É dessa forma que, na década de 1970, no bojo das discussões sobre o 'complexo militar-industrial', a saúde ganha adeptos daquilo que foi denominado 'complexo médico-industrial', que, com a contribuição de Relman (1980), passa a ser entendido a partir das transformações dos serviços de saúde no movimento do grande capital.

Hoje, do ponto de vista econômico, a indústria da saúde, em termos mundiais, só perde em dinamismo inovativo e investimentos para a indústria bélica (TEMPORÃO, 2008). Neste sentido, Gelijns e Rosemberg (1995:4) sugerem a existência de um sistema nacional de inovação em saúde. Nas palavras desses autores: 
innovation requires not only the crossing of disciplinary boundaries, but it also increasingly involves the crossing of institutional boundaries. In fact, medical innovation depends heavily on interactions between universities, particularly academic medical centers, and industrial firms.

No Brasil, essa discussão nos remete aos anos 1980, com a contribuição de Cordeiro (1980). Sua preocupação central estava vinculada ao consumo e à produção de medicamentos. Como bem resumiu Andreazzi e Kornis (2008:1410):

o aprofundamento da análise sobre o consumo de medicamentos permitiu identificar um aspecto crítico para a indústria produtora desses bens na criação de necessidades sociais de consumo e na influência sobre a prática médica.

Essa influência e a própria dependência na importação de medicamentos alertavam para a constituição de uma política que privilegiasse a produção nacional de elementos componentes de todas as cadeias produtivas ligada à saúde.

Como resultado dessas discussões no Brasil, em 1994 é realizada a I Conferencia Nacional de Ciência Tecnologia em Saúde. Mais tarde passamos a observar a consolidação da importância da inovação em saúde através: de financiamentos, a exemplo do Fundo Setorial da Saúde, gerenciado pela FINEP, que será devidamente reportado no capítulo 3; da criação do Departamento de Ciência e Tecnologia em Saúde (DECIT), no Ministério da Saúde, em 2000; e da divulgação, em 2002, de um documento intitulado "Política Nacional de Ciência, Tecnologia e Inovação em Saúde: uma proposta" pela Associação Brasileira de Saúde Coletiva (ABRASCO) (PEREIRA; BALTAR e MELLO, 2004:2).

Do ponto de vista teórico, essa discussão ganha ainda mais fôlego com as proposições de Carlos Gadelha (2002; 2003; 2006) acerca do conceito de 
Complexo Industrial da Saúde (CIS). A partir de então, esse conceito passa a servir de base para uma nova atuação do Estado, no sentido de articular políticas industriais e tecnológicas do setor saúde com a política de proteção social de saúde. Nas palavras do autor, o CIS:

privilegia o sistema produtivo de bens e serviços (este último ramo se inclui aqui porque também a prestação de serviços assistenciais passa a seguir uma lógica típica da atividade industrial), enfatizando a dinâmica específica de cada setor e, principalmente, suas interações que envolvem relações de mercado (compra e venda de bens e serviços), tecnológicas (geração e difusão de conhecimentos no âmbito dos paradigmas tecnológicos dominantes) e político-institucionais (interações no âmbito do sistema de saúde envolvendo atividades de promoção e regulação).

(GADELHA, 2003:319)

Os setores industriais ligados à saúde estão divididos em dois grupos: empresas de base química e biotecnológica; e equipamento médico-hospitalar. Em relação ao primeiro, o autor chama a atenção para o fato de que, hoje, "há uma tendência de 'transbordamento' da indústria farmacêutica, ampliando suas fronteiras para os demais segmentos como já está ocorrendo na área de vacinas" (idem:524). Já no segundo, há evidências de atividades díspares, cuja importância deve-se ao seu intenso grau e potencial de inovação, a partir da incorporação do paradigma microeletrônico, e ao seu grande impacto nos serviços de saúde, o que representa uma fonte permanente de mudanças nas práticas assistenciais, trazendo constantemente para o debate a tensão entre a lógica da indústria e a sanitária.

Os setores prestadores de serviços, que seriam uma terceira via, "organizam a cadeia de suprimento dos produtos industriais em saúde, articulando o consumo por parte dos cidadãos no espaço público e privado" (op. Cit::526). Considerando a difusão das inovações, os setores de serviços se caracterizam como fornecedores, já que o progresso técnico passa a ser incorporado, em grande medida, nos produtos que adquirem, tais como medicamentos, equipamentos e novos materiais. Esses setores dão 
organicidade ao complexo, pois é no de serviços que conflui a produção de todos os setores industriais, dando motricidade ao complexo. A expansão, contração ou direcionamento compras relacionadas ao complexo exercem um impacto determinante na dinâmica de acumulação e inovação dos demais segmentos.

Para Gadelha, Quental e Fialho (2003:49) não só essa complexa gama de indústrias atreladas ao setor da saúde, como, também, o fato de haver uma demanda da sociedade por serviços devem ser entendidas com base em na perspectiva sistêmica da inovação.

Portanto, podemos delimitar o sistema nacional de inovação em saúde nacional de inovação em saúde como uma construção econômica, política e institucional para a qual confluem fortes interesses, advindos tanto das estratégias empresariais nas distintas indústrias da saúde e nas instituições de C\&T quanto da pressão da sociedade civil pela prestação de serviços de saúde que atendam aos requisitos de acesso, de ações integrais e de equidade.

(idem)

Gadelha (2006:49) avança em sua argumentação no sentido de que o CIS compreende um núcleo estrutural da vulnerabilidade externa do país e, por isso mesmo deve ser capaz de aproximar a base científica e tecnológica do país às necessidades efetivas da saúde brasileira.

Nessa perspectiva Gadelha (idem:15) aponta a fundamental necessidade de colocar a agenda de pesquisa e de política em saúde voltada para o desenvolvimento econômico do próprio país. Um de seus principais argumentos, de que trataremos no Capítulo 4, é a vulnerabilidade externa do setor em função das importações. No estudo em questão, Gadelha (op. Cit:18) demonstra que o déficit na balança comercial em relação aos produtos do CIS, entre 1997 e 2004, está completamente ligado ao câmbio, fato que não pode ser controlado pelo governo e que, por sua vez, pode fazer com que os gastos em saúde no país, no caso de uma desvalorização do real saltem de maneira considerável ou, no caso de valorização, aumente significativamente as importações causando problemas às indústrias nacionais do setor. 
De qualquer forma, podemos dizer que esses estudos e discussões foram fundamentais para a contemplação dos segmentos econômicos ligados ao CIS em, basicamente, todas as políticas e instituições de promoção e efetivação de fomento à inovação tecnológica no país nos últimos anos; incluindo a criação de uma secretaria específica, dentro do Ministério da Saúde, chamada de Secretaria de Ciência, Tecnologia e Insumos Estratégicos (SCTIE), com um departamento exclusivo para assuntos ligados ao $\mathrm{CIS}$, o Departamento do Complexo Industrial e Inovação em Saúde (DCIIS), em 2009. Porém, uma análise mais aprofundada sobre inserção das atividades econômicas ligadas à saúde nas políticas de inovação, será realizada devidamente no capítulo 4.

Feita essa apreciação sobre as contribuições teóricas acerca da inovação tecnológica, introduziremos nosso propósito estrutural, que é a aproximação teórica da inovação com a ciência geográfica, para que no próximo capítulo possamos justificar nossa abordagem da inovação tecnológica como elemento central da geopolítica brasileira.

\subsection{Geografia e inovação tecnológica}

A ideia de reservar um item voltado às questões teóricas da inovação e outro às reflexões presentes na disciplina geográfica surgiu de uma inquietação relativa à presença, ainda, pouco expressiva da inovação nos textos da geografia brasileira. Como exemplo, poderíamos citar o "XVI Encontro Nacional de Geógrafos", realizado no ano de 2010. Dentre os mais de dois mil trabalhos inscritos, apenas três ${ }^{11}$ fizeram menção ao termo inovação no título, sendo que Gonçalves (2010) dedica seu trabalho à inovação no ensino de geografia e não aos processos de inovação tecnológica propriamente ditos.

\footnotetext{
${ }^{11}$ Ver Buttner (2010); Gonçalves (2010); Viana e Fernandes (2010).
} 
Ainda que não presente nesse encontro citado anteriormente, o grupo que tem realizado estudos voltados à inovação na geografia está situado na Universidade Federal do Pernambuco (UFPE), intitulado Grupo de Pesquisa em Inovação, Tecnologia e Território (GRITT). Tendo como principal coordenadora a Professora Ana Cristina Fernandes, o grupo, ao longo dos últimos anos, tem se dedicado ao estudo da dimensão territorial da inovação seguindo algumas frentes, entre elas: estudos sobre as interações entre universidades e empresas; aspectos da temática da inovação e suas implicações para o desenvolvimento; políticas de cunho regional ligadas aos processos inovativos. Entre suas ações, o GRITT foi o responsável pela realização do I Simpósio Internacional de Geografia do Conhecimento e da Inovação, em junho de 2011, com o intuito de promover a ampliação do debate e da interação entre pesquisas com preocupações voltadas à geografia e à inovação. As especificidades desses projetos serão aprofundadas ainda neste capítulo, quando retomarmos alguns estudos recentes da geografia sobre a inovação.

Seria incorreto afirmar que apenas esse grupo de pesquisadores e professores se debruça sobre essa temática. É claro que outros exemplos pontuais oriundos das faculdades de geografia também são verificados, como no caso de Silva (2004), que fez uma abordagem sobre a difusão da inovação na globalização, ou Tartaruga (2010), que estabeleceu uma aproximação entre a dimensão territorial e o papel das universidades no Rio Grande do Sul. Por outro lado, o que verificamos é que outros grupos, que não pertencem aos departamentos de geografia, têm ganho notoriedade nas reflexões sobre a questão do espaço e da inovação.

Um desses grupos está situado no Departamento de Engenharia da Produção, da Faculdade Politécnica da Universidade de São Paulo. Entre os temas de pesquisas que contam com financiamentos e vêm sendo desenvolvidos nos últimos anos, podemos ressaltar novamente estudos sobre as interações universidades e empresas ${ }^{12}$; sistemas regionais de inovação; arranjos produtivos locais, com ênfase em alguns setores industriais brasileiros;

${ }^{12}$ Ver Garcia et alli. (2011). 
e, por fim, o projeto mais recente que enfatiza no próprio título a questão da geografia, "Geografia e Inovação: um estudo dos efeitos da aglomeração industrial e suas implicações de políticas", financiado pelo CNPq e coordenado pelo Professor Renato de Castro Garcia.

Outro grupo dedicado à discussão em pauta é parte do Centro de Desenvolvimento e Planejamento Regional (CEDEPLAR) da Universidade Federal de Minas Gerais (UFMG), ligado aos programas de pós-graduação em Demografia e Economia da universidade mineira. No CEDEPLAR, o grupo que está mais claramente vinculado à temática é o de "Estudos sobre Desenvolvimento Regional Industrial e Tecnológico". Seus coordenadores, Clélio Campolina Diniz e Mauro Borges Lemos, foram também responsáveis pela realização, no ano de 2001, do seminário "Economia e Espaço", que resultou na publicação de um livro com as contribuições e reflexões presentes no seminário. É nessa publicação, intitulada "Economia e Território" ${ }^{13}$, que alguns textos procuraram fazer a abordagem de temas ligados à geografia e à inovação, a exemplo de Diniz e Gonçalves (2005), Conti (2005), Suzigan, Garcia e Furtado (2005), Lastres e Cassiolato (2005).

É fundamental frisar que os grupos anteriormente citados foram selecionados em função de suas dedicações exclusivas a temas que tenham como elemento central a questão espacial, indiferente às suas abordagens conceituais e teóricas. Esta justificativa se torna necessária para que fique clara a ausência de diversos outros grupos que trabalham a temática da inovação, mas que não possuem focos claros na questão espacial. Um exemplo pode ser verificado no Departamento de Política Científica e Tecnológica (DPCT) da Universidade Estadual de Campinas (UNICAMP), que apesar de fazer parte do Instituto de Geociências, ao qual está vinculado o Departamento de Geografia, não possui linhas específicas para estudos espaciais envolvendo a inovação tecnológica, o que não diminui sua importância, sobretudo ligada às análises dos financiamentos para inovação no Brasil, assim como a história da consolidação do sistema nacional de ciência, tecnologia e inovação.

\footnotetext{
${ }^{13}$ Ver Diniz e Lemos (2005).
} 
Se observarmos as temáticas sobre Geografia e inovação que pautam as pesquisas dos grupos anteriormente citados, a ênfase, geralmente, recai sobre reflexões voltadas ao tema da concentração espacial das atividades com alta intensidade de P\&D ou seus impactos regionais. Não que todas as pesquisas fiquem restritas a isso, mas em boa parte verificamos essa tendência.

Do ponto de vista mais geral, ou seja, da produção sobre inovação na Geografia, não apenas nos grupos brasileiros, uma abordagem tradicional nos remeteria, sem dúvida, à Geografia Econômica e à Geografia Regional ${ }^{14}$. O conceito de inovação tecnológica, por si, já indica sua proximidade com a economia. Arbix (2010:169), quando diferencia inovação de invenção, enfatiza que "na economia real a inovação se refere a uma primeira comercialização de uma ideia ou projeto; por isso mesmo, seu locus privilegiado é a empresa, capaz de manter sintonia fina com a produção e a comercialização". Ou seja, há claramente uma noção de mercado envolvida. Ainda que tenhamos críticas $^{15}$, o termo inovação é a referência utilizada para remeter a uma invenção que foi absorvida pelo mercado e, por isso mesmo, elemento central de análise de problemáticas relacionadas ao espaço e a economia.

Na Geografia, Torsten Hagerstrand foi o precursor das análises sobre a difusão espacial das inovações ${ }^{16}$ (SANTOS, 1997[1978]:75). Em um dos seus primeiros estudos, Hagerstrand (1962:358) procurou evidenciar, a partir do

\footnotetext{
${ }^{14}$ Egler (1995) realizou uma aproximação dessas duas correntes na Geografia. Restando alguns clássicos da Economia e da Geografia Econômica, o autor discutiu a questão regional no Brasil.

${ }^{15}$ Dagnino e Thomas (2001) apontam que a política científica e tecnológica no Brasil apresenta aspectos muito centrados no que denominam "enfoque gerencial", ou seja, o fato do estímulo à ciência e tecnologia se dar por meio da empresa privada e da difusão de métodos gerenciais. Para Dagnino (2004) essa abordagem, foco na empresa privada, é questionável já que se baseia numa concepção "Instrumental da Tecnociência" e, portanto, não se adequaria à promoção do desenvolvimento econômico e social dos países periféricos. Atualmente, o foco de suas análises está centrado no desenvolvimento das Tecnologias Sociais com vistas à inclusão social (DAGNINO, 2010).

${ }^{16}$ Silva (1995:26) identifica em Carl Sauer, mas especificamente em seu estudo, de 1952, Agricultural Origins and Dispersal, as prerrogativas desenvolvidas por Hagerstrand. Segundo ele, Sauer havia utilizado as evidências dos arqueólogos e antropólogos sobre a localização de plantas e animais domesticados para seu estudo sobre as práticas agrícolas dispersas no mundo. Sua "preocupação era verificar se a configuração espacial da área cultural era o resultado de um ou vários processos de difusão que ocorreriam separados e independentemente" (idem). A contrapartida desses estudos seria revista por Hagerstrand, na década de 1950.
} 
exemplo da difusão dos rádios e automóveis, como as condicionantes econômicas e sociais poderiam ser retardatárias na adoção de novas tecnologias. A ideia central de seus estudos se pautava no fato de que a implementação de novas máquinas ou de novas tecnologias deveria ser seguida de apreciações sobre cada pedaço de território impactado e de como as ações humanas também poderiam sofrer transformações com essas novidades (HAGERSTRAND, 1967:1). A partir de um complexo jogo de indicadores - agrícolas e gerais, como serviço de correio e telefone -, Hagerstrand usou métodos quantitativos para mapear inovações na agricultura e quais componentes sócioculturais favoreciam ou dificultavam o espraiamento delas.

Outro autor identificado com essa teorização é Everett M. Rogers (1962). Em sua visão, haveria quatro elementos centrais da difusão de inovações: a inovação em si; sua comunicação de um indivíduo para outro; esta no sistema social; sua duração. Sua preocupação era basicamente como a inovação poderia ser apreendida por grupos humanos ou indivíduos e de que modo isso facilitaria ou dificultaria sua adoção.

De qualquer forma, a obra mais referendada nas discussões sobre difusão de inovação foi a de Hagerstrand. Para Silva (1995:33), a referência para a utilização mais efetiva desse autor foi Lawrence A. Brown, com sua obra Diffusion Process and Location: a conceptual framework (1968) e, posteriormente, com um estudo em parceria com Kevin Cox, intitulado Empirical Regularities in the Difusion of Innovation (1971).

Santos (1997[1978]:75) identifica que essa teorização proposta por Hagerstrand e tratada por outros autores acabou sendo utilizada de maneira indiscriminada e como instrumento de marketing ${ }^{17}$. Santos (idem) procurava, naquele momento, enfatizar que a quantificação exagerada dos trabalhos

\footnotetext{
${ }^{17}$ Santos (1979:33) também enfatiza a abordagem dessa teoria de forma utilitária nos EUA. "O problema de saber onde e porque localizar (um supermercado, uma fábrica, um distrito de uma cidade, ou mesmo uma nova cidade) tem sido frequência prioritária desde que os inesperados índices de crescimento dos Estados Unidos criaram uma demanda para aqueles - e apenas aqueles - instrumentos de pesquisa que pudessem fazê-lo ascender novamente. As preocupações de Hagerstrand voltaram-se para a construção de modelos matemáticos, coincidindo com o comum interesse de universidades e da economia americana".
} 
posteriores à Hagerstrand acabou gerando a denominada 'regra da difusão crescente e hierárquica', destinada a impor a ideia de que, havendo crescimento econômico e riqueza localizados em um ponto do país, a tendência natural seria uma difusão 'milagrosa' pelo resto da nação. Fato que mereceria uma análise mais aprofundada quanto a sua efetividade, assim como critérios mais qualitativos que justificassem a quantificação em questão.

Essa crítica é um exemplo claro daquilo que foi pontuado por Silva (1995:26):

No âmbito da Geografia brasileira os estudos de difusão de inovações perderam prestígio a partir dos anos $80 \mathrm{com}$ o advento da chamada Geografia Radical que se opunha a Geografia Teórico-Quantitativa, base sobre a qual se apoiavam os estudos sobre difusão espacial. Em função de uma postura crítica aparentemente marxista, os estudos sobre difusão espacial foram deixados de lado, tendo sido considerados ideológicos e de pouca substância. Os aspectos selecionados para a análise da difusão estavam desligados de qualquer contexto geral. Aparecem críticas de todos os lados, principalmente no tocante à ausência da dimensão temporal na interpretação dos processos espaciais. Enfim, as análises empíricas e teóricas da difusão têm sido amiúde considerados (sic) anódinas.

Em paralelo a esse afastamento da quantificação sobre inovação na Geografia, surgem os estudos econômicos e regionais acerca do tema. Contudo, nessas abordagens, as elucubrações sobre a dimensão espacial da inovação passaram a contar com uma série de trabalhos da chamada economia espacial. Nesse ponto da tese, o que pretendemos referendar são, basicamente, alguns autores e publicações internacionais e nacionais, de maneira a pontuar um foco fundamental das discussões dos processos espaciais sobre inovação.

Miglino (2003) fez um esforço no sentido de delimitar, na literatura internacional, os autores e as escolas que realizaram importantes estudos sobre as abordagens entre espaço e inovação. Sua escolha em relação aos 
estudos foi dada pela percepção de forte tendência analítica sobre a concentração geográfica ou aglomeração das atividades econômicas no espaço, explicadas por diversos prismas analíticos e autores (idem:51).

Desta forma, a autora definiu cinco grandes contribuições ${ }^{18}$. A primeira seria a dos distritos industriais, com a proposições mais conhecida de Giacomo Becattini. A segunda escola estaria relacionada aos pesquisadores do milieux innovateurs, denominado GREMI, criado em 1984 por Philippe Aydalot ${ }^{19}$. Em seguida, aparecem dois autores que formam a chamada Escola Californiana de Geografia, Allan Scoot e Michael Storper. A quarta, que enfatiza a teoria dos rendimentos crescentes e tem como principal autor Brian Arthur. E, por fim, os estudos de Paul Krugman. Dada a variedade de temas, faremos apenas uma breve referência à escola dos distritos industriais, pelo lado da economia, e às contribuições de Storper, pela Geografia, passando, então, para alguns autores brasileiros que se inserem nesse debate.

Capello (2009:42) aponta Giacomo Becattini como o primeiro a teorizar sobre os distritos industriais, enfatizando que as economias de aglomeração podem ser consideradas fontes da competitividade territorial. Nesta escola, identifica-se que devido à importância específica de cada distrito (aspectos culturais, valores, identidade comum e intercâmbios, relação de cooperação e competição) as empresas localizam-se nos territórios não de maneira 'acidental' e sim, favorecida por fatores como infraestrutura. Segundo Becattini (2000, apud Silva, 2003:54), há uma série de processos elementares fundamentais para a constituição da 'distritalidade', como: subdivisão progressiva do processo produtivo central do distrito; sedimentação institucional das praxes distritais premiadas e eliminação das punidas; integração entre saber contextual e saber codificado no seio dos processos produtivos típicos dos distritos; formação de representações e instituições de

\footnotetext{
${ }^{18}$ Os recortes utilizados pela autora foram: a interpretação dos selecionados acerca dos fatores determinantes da localização das atividades; suas concepções sobre a inovação ou sobre a mudança tecnológica; e os nexos e interpretações entre mudanças tecnológicas e a localização das atividades econômicas no espaço (idem: 5).

${ }^{19}$ Benko (1999:140) nos recorda que a noção de meio inovador foi definida por C. Perrin. Essa seria a referência "a um conjunto territorializado no qual as redes inovadoras se desenvolvem pela aprendizagem que seus atores fazem das transações multilaterais geradoras de externalidades inerentes à inovação e por convergência das aprendizagens com formas cada vez mais competitivas de criação tecnológica".
} 
interface entre as variadas especializações; interiorização de alguns resultados das praxes distritais; comaturação de valores e saberes no desenvolvimento do distrito, chamada de 'atmosfera industrial'. Para Becattini (2004:106) as 'firmas distritais' apresentam maior competitividade que as não industriais, assim como os próprios distritos têm maior competitividade internacional que outras áreas produtivas.

Do ponto de vista regional, Capello e Nijkamp (2009:1) destacam o retorno dessa abordagem ao 'palco' nas últimas décadas. Essa alusão está pautada na evolução e no reconhecimento dos estudos do desenvolvimento regional, entendido não só como questão de eficiência pela economia política, mas, sobretudo, pelo fato do desenvolvimento econômico ter diferentes graus de variedade espacial, que por sua vez, tem na região um locus profícuo de análise, sobretudo se pensarmos nas disparidades regionais dos sistemas de produção e das condições sociais. Assim, a busca por uma eficiência nas políticas públicas, assim como o desenvolvimento de pesquisas que deem subsídios para pensar as desigualdades regionais se tornaram elementos fundamentais dos estudos em Geografia econômica, economia regional, ciência regional e teoria do crescimento econômico.

No caso da Geografia econômica, Scott (2007[1999]) procurou sistematizar os principais estudos, enfatizando três períodos: na década de 1960, quando o enfoque era dado sobre a análise espacial e a ciência regional; nos anos 1970, com a introdução de uma forte acepção marxista; e, a partir de 1980, com crescimento do número de trabalhos que trouxeram à tona a questão regional, do qual o próprio autor faz parte. O debate regional, especificamente, como bem analisado por Benko e Lipietz (1994), passou a tratar questões relacionadas à hierarquia urbana, ao desenvolvimento endógeno, aos próprios distritos industriais, mas sempre procurando evidências sobre o sucesso de determinados pontos do planeta em relação às suas capacidades de efetivar atividades produtivas específicas.

Scott e Storper (2007[2003]:18) centraram o debate regional no rol de elementos explicativos do crescimento econômico. Esses autores, 
preocupados com a exacerbação das teorias ortodoxas ${ }^{20}$ nas teorias do desenvolvimento, enfatizaram o papel da região como fundamento crítico do processo de desenvolvimento e a inovação tecnológica teria importância central no desenvolvimento regional.

Especificamente, a preocupação com a inovação e a região foi estruturada por Storper (1997). Nesta obra, o autor estabelece claros nexos entre a inovação tecnológica e a questão regional. Na sua visão, desde a década de 1970 diversos estudos passaram a investigar o desenvolvimento regional com foco na desigual distribuição das indústrias de alta tecnologia e nos fatores que justificavam suas aglomerações (idem:15). Para Miglino (2003:77) os trabalhos anteriores a esse, tanto de Storper quanto da chamada Escola Californiana deram muito valor aos 'custos de transação insumoproduto'. Porém, Storper (1997:107-163) passa a utilizar novos

elementos explicativos, não restritamente econômicos, como as relações interpessoais dos agentes, os ativos relacionais e a necessidade dos contatos face a face, além do processo de interatividade do aprendizado como processo fundamental da inovação tecnológica.

(MIGLINO, 2003:77-97)

O resultado seria que para cada lógica localizacional haveria uma arquitetura de sistemas de inovação com diferentes graus de territorialização e mixes de qualificação de componentes territoriais. Do ponto de vista regional, essas assertivas são pensadas pelos casos do Nordeste Central da Itália, da llê-de-France e da Califórnia. Sua conclusão aponta para o fato da dinâmica dos sistemas tecnológicos de produção consistem em clusters de firmas com a presença de uma intricada divisão social do trabalho, evidenciada no nível regional (STORPER, 1997:162).

${ }^{20}$ Scott e Storper (idem) argumentam que disciplina fiscal, responsabilidade monetária, medidas de abertura de mercado, garantias de propriedade privada, estabilidade política e governança democrática não explicam sozinhas a questão dos diferentes tipos de desenvolvimento. 
$\mathrm{Na}$ vertente brasileira, Clélio Campolina Diniz é um dos grandes expoentes dessa discussão. Para Diniz (2001:7), a formação dos blocos regionais é uma evidência clara de que com a globalização não alcançamos nem homogeneidade espacial da produção muito menos a socialização dos benefícios sociais. O debate regional, em sua visão, é urgente e capaz de pensar a economia pelo espaço. O papel da tecnologia nessa reflexão torna-se fundamental. Em uma sociedade crescentemente dominada pelo conhecimento, as vantagens comparativas estáticas ou ricardianas, com ênfase nos recursos naturais, dão lugar de destaque às vantagens construídas e criadas, cuja base está exatamente na capacidade diferenciada de gerar conhecimento e inovação (idem:10). Porém, essa nova sociedade está pontuada diferencialmente no espaço, sendo a região um elemento estrutural de análise.

Cada região, localidade ou setor segue padrões evolucionários distintos, não sendo possível copiar ou reproduzir experiências histórias. As interações formais e informais dos agentes e instituições, enraizadas no ambiente local, estabelecem redes inovativas, onde a comunicação, a cooperação e a coordenação dos atores agem como elementos facilitadores do processo de inovação.

(op. Cit.:12)

No entanto, convém observar que Diniz e Gonçalves (2005:139) incitam cautela quanto à exacerbação da proximidade geográfica como fonte per se do sucesso das experiências de geração do conhecimento. $\mathrm{Na}$ visão desses autores, muitas vezes os atores locais não agem a favor da interação e da sinergia, uma vez que cada experiência é única e não reprodutível, exatamente pelo fato dos conteúdos imateriais serem diferentes em cada território.

Os autores seguem o estudo empírico com base em evidências regionais e locais, no Brasil, em setores ligados à tecnologia e inovação. Em suas análises, Diniz e Gonçalves (idem:145-165) partem de uma base de dados sobre a infra-estrutura ${ }^{21}$ do conhecimento, no Brasil, aliada à distribuição

${ }^{21}$ Os autores utilizaram o sistema acadêmico-universitário (número de instituições, professores
e alunos) e o de pesquisa. As bases estatísticas foram o Censo do Ensino Superior do 
da base produtiva e as potencialidades locais em relação às atividades tecnológicas. A conclusão do estudo aponta para a existência de três grandes macrorregiões: a Região Dinâmica, composta pelo Sul e Sudeste; a Região Atrasada, que corresponde ao Nordeste; e a Região Vazia, que compreende o Centro-Oeste e o Norte. Ainda, os autores apontam para um aprofundamento dos desníveis regionais em relação à indústria do conhecimento, dado pela articulação entre a infraestrutura acadêmica e de pesquisa com as bases produtivas regionais.

Ana Cristina Fernandes, pela vertente da Geografia, procura estabelecer uma visão mais crítica da inovação tecnológica e do espaço, seus estudos são baseados em diferentes enfoques, incluindo os regionais. Nesta temática, Lima e Fernandes (2009) focaram o trabalho na perspectiva da tecnologia e sua implicação em economias retardatárias, tanto do ponto de vista dos países quanto da questão regional dentro do Brasil. Para esses autores, a interação entre ICTs e empresas ganha ainda mais importância em países retardatários. A proximidade geográfica para o transbordamento do conhecimento cientifico e tecnológico pode, dessa forma, dar uma contribuição fundamental das instituições para melhorar as capacidades inovadoras nesses países retardatários. No Brasil, o foco fica por conta do Nordeste. Lima e Fernandes (idem:309-310) ressaltam que, a despeito das políticas nacionais de inovação ainda não estarem expressas no número de empresas inovadoras, há uma tendência de aumento do número dessas empresas, inclusive no Nordeste. Assim, o estudo passa a analisar os gargalos e alguns casos de atividades específicas como a fruticultura irrigada e a produção de petróleo e gás.

Outro texto, a partir de um enfoque mais crítico, foi realizado por Machado e Fernandes (2011). O centro do debate foi a responsabilidade social empresarial (RSE) e o ordenamento do território com base na geografia crítica. Para os autores, a gestão do território deve levar em conta a intencionalidade, traduzida por uma racionalidade técnico científica dos atores que o organizam. A implementação da RSE permitiria fluxo de normas, a direção e sentido das ordens, de tal modo que as implicações de cada combinação das variáveis Nacional de Desenvolvimento Científico e Tecnológico (CNPq). 
podem explicitar a realização de maior ou menor verticalidade/horizontalidade. Alguns comportamentos territoriais da RSE que expressam as práticas espaciais, tal como o controle de determinado território, o controle dos sistemas de produção de conhecimento e a inovação, entre outros. A gestão do território revelar-se-ia, portanto, mais hierárquica e seletiva, exatamente pelo controle desses fatores supracitados. O que se conclui é que a RSE revela uma contradição estabelecida entre a pretensa promoção de cidadania e sustentabilidade por parte da RSE e o compromisso das empresas com a produção de lucro. Assim, a "gestão territorial corporativa impõe uma seletividade das ações empreendidas, que confrontadas com o ideário público de se fazer política põe em confronto uma lógica da eficiência e uma lógica da equidade" (idem: 381).

Deve ficar claro, neste ponto, que estudos da questão espacial e da inovação não se resumem a esses autores, nossa escolha por apontá-los diz respeito à relevância de suas contribuições, tanto no Brasil quanto no plano internacional. Outros exemplos de abordagens da inovação e do espaço podem ser encontrados nas publicações da revista Economic Geography e, com análises regionais, na revista espanhola Investigaciones Regionales ${ }^{22}$.

Em relação à primeira, não são encontrados tantos artigos voltados à questão regional, mas diversas abordagens extremamente interessantes, como o estudo desenvolvido por Saxenian e Sobel (2003). Estes autores realizaram uma pesquisa com foco no papel que a primeira geração de imigrantes profissionais de Taiwan nos EUA teve no desenvolvimento institucional no seu país de origem. Uma das conclusões a que chegaram foi que a criação de redes de trabalho através de venture capital sugere um importante processo de aprendizado e experimentação em contextos particulares, sendo possível verificar inovações, a partir dessas redes, nas instituições públicas e no próprio processo de organização da produção de seu país de origem.

Já na segunda, os trabalhos evidenciam a aproximação com a questão regional. Um claro exemplo pode ser dado pelo trabalho de Verdú (2003). O

${ }^{22}$ Ver Duch, Montolio e Mediavilla (2009); Escriba e Murgui (2007); Quesada (2008); Verdú (2003); e Fratesi (2007). 
autor enfatiza que as políticas de promoção empresarial, na Europa, estão inseridas em contextos regionais evidenciados pelos Centros Tecnológicos. A eficácia dessa política, por sua vez, depende da possibilidade de combinar instrumentos como mecanismos de transferência, via incentivos financeiros, e a capacidade regulatória, que dá apoio às atividades intensivas em tecnologia.

A importância da apreciação, feita neste item, sobre alguns enfoques das relações entre inovação e espaço é fundamental para situar o debate dominante do tema. Pelo fato de termos procurado um caminho 'inovador', com o perdão do trocadilho, da abordagem da inovação pela Geografia, não demos prioridade teórica à questão regional. De forma alguma negamos essa relevante contribuição para os estudos espaciais, porém pensar a inovação partindo de uma visão estratégica da política no território e, portanto, geopolítica, parece-nos essencial para uma ampliação deste debate, que já é tão rico nos estudos regionais. A seguir, realizaremos um enfoque teóricometodológico da Geografia e da questão do Estado, para servir de base para o desenvolvimento de uma abordagem geopolítica da inovação tecnológica.

\subsubsection{Pressupostos para uma abordagem geopolítica da inovação}

Assim como todas as ciências sociais, a Geografia possui, ao longo de sua história, trajetórias teóricas marcadas por debates, aproximações e críticas. Seu caráter de lidar com aspectos físicos e humanos da Terra, em muitos casos, promove debates que beiram o senso comum, sendo alguns de seus conceitos estruturantes parte do vocabulário usado no cotidiano por inúmeras pessoas. Lugar e região são denominações claras da afirmativa anterior e usadas por diversas áreas do conhecimento. A região, por exemplo, não só é um conceito usual do dia a dia como objeto de políticas públicas voltadas à administração. Na saúde, para se ter uma ideia, como finalidade da organização dos serviços, a regionalização é usada na Inglaterra desde 1920, 
como evidenciado no Informe Dawson, (ALBUQUERQUE, MELLO e IOZZI, 2011:177).

No sentido de dar clareza e solidez metodológica, exatamente evitando o uso de conceitos de maneira equivocada, iniciamos este item com o esclarecimento do arcabouço teórico-metodológico que norteará as reflexões contidas na tese. Se observados os caminhos teóricos que a ciência geográfica trilhou desde sua efetivação nas universidades, a Geografia Política, a Geopolítica, a influencia marxista, a Geografia Teorética, com suas quantificações, todas oferecem importantes contribuições. No nosso caso, a base teórica da tese tem como fundamental autor Milton Santos e a Geografia crítica. Mesmo que nossa discussão se dê com ênfase na Geopolítica. Afinal, o pensamento geopolítico parte das reflexões sobre o espaço e refletir sobre o espaço, na nossa concepção, é refletir sobre 'sistemas de objetos' e 'sistemas de ações', indissociavelmente.

A definição do objeto de estudo da ciência geográfica deve aparecer como elemento central em discussões metodológicas. Dosse (2007:383) chega a afirmar que a Geografia se apresenta como uma disciplina sem objeto. Essa importância, ou seja, a definição do objeto de estudo, diversas vezes negligenciada, vem sendo anunciada como central por teóricos como Isnard (1982) e Santos (1997), em cujos trabalhos podemos perceber uma evolução metodológica sem precedentes, já que essa definição não só permite um corpo teórico rígido, como capaz de dialogar com outras ciências, sem cometer injustiças conceituais.

Para esses dois autores, o objeto de estudo da Geografia é o espaço geográfico. Em particular, Santos (1997:51) define o conceito de espaço geográfico como "um conjunto indissociável e também contraditório, de sistemas de objetos e sistemas de ações, não considerados isoladamente, mas como o quadro único na qual a história se dá”. A partir dessa definição, podemos fazer duas observações: em primeiro lugar, a busca pela totalidade, ou seja, o espaço como aquilo que é material, concreto e nunca dissociado do plano das ações, das políticas que the dão vida; em segundo lugar, o espaço como o centro das preocupações em Geografia. 
Diversas ciências trazem em seus bojos discussões subjetivas, perceptivas, mas que, no caso de um estudo espacial, tendo em vista as relações entre a produção do espaço e como esse espaço construído interfere no tecido social, não nos permitem estabelecer relações entre o individuo e o espaço $^{23}$, já que cada indivíduo tem um olhar sobre o espaço. São essas prerrogativas que, ao nosso entendimento, estabelecem uma coerência interna à disciplina, fundamental para o diálogo com outras disciplinas.

A partir dessa perspectiva, o espaço é uma realidade objetiva, constituída pelo par indissociável 'sistema de objetos' e 'sistema de ações'. Em relação ao sistema de objetos, o papel das técnicas na constituição do espaço geográfico se configura como algo mais palpável. Em outras palavras, são as materialidades presentes no cotidiano que, claramente, evidenciam a conformação dos sistemas técnicos.

Em vários momentos o trabalho do geógrafo Milton Santos eleva a questão da técnica ao cerne da ciência geográfica, sobretudo, quando pensado o próprio objeto de estudo da disciplina: o espaço geográfico. Porém houve uma negligência do espaço nos estudos sobre a técnica denunciada por Santos (1997:27), quando tratou de abordar diversos autores, tanto ligados à geografia, quanto a outras disciplinas.

Nas palavras de Santos (2008[1994]:57), técnicas "são, todavia, um dos dados explicativos do espaço". A adoção de um instrumento técnico é uma forma de ação, assim como exerce função num determinado tempo e lugar. Ou seja, seu uso atribui condições técnicas e não se dá de forma isolada, mas por um conjunto de técnicas, que, nos países subdesenvolvidos, está ligado às formas de produção dos países desenvolvidos (idem).

Esse raciocínio nos leva a questionar como se geografizam as técnicas e não apenas como se dão suas gêneses, ou seja, é pensar no conteúdo

\footnotetext{
${ }^{23}$ Esta breve reflexão é fundamental para que possamos definir uma perspectiva alheia àquela da geografia da percepção. Para Santos (1997[1978]:69), essa escola, ao limitar-se à análise das percepções dos objetos geográficos, não levou em conta duas coisas: "De um lado, a percepção individual não é o conhecimento; de outra forma, a coisa não seria objetiva e a própria teoria da percepção seria incompleta, senão inútil. De outro lado, a simples apreensão da coisa, por seu aspecto ou por sua estrutura externa, não nos dá o objeto em si mesmo, o que ele apresenta, mas não o que ele representa" (idem).
} 
político-territorial de análise, fundamental à consolidação de determinados elementos técnicos no espaço. E é nesse sentido que nos aproximamos de Benakouche (1999:2):

entender o significado da técnica é uma tarefa essencialmente política, na medida em que uma clareza sobre a questão é fundamental tanto na tomada de decisões a respeito do seu desenvolvimento, como no planejamento da sua adoção ou uso, seja por indivíduos, unidades familiares ou organizações.

Esta reflexão levada a cabo na discussão da inovação tecnológica, sob o ponto de vista geográfico, nos permite questionar por que desenvolvemos tal ou qual tecnologia, ou por que importamos. Se algo está sendo imposto, ou se estamos procurando alternativas próprias de desenvolvimento nacional e, até mesmo, se quisermos refletir sobre quais políticas devem ser aplicadas para que haja uma verdadeira ultrapassagem de modelos baseados apenas na importação de determinadas tecnologias. Não se trata, pois, de um ufanismo simplista, mas de defesa e desenvolvimento dos conteúdos nacionais, conforme necessidades e prerrogativas internas aos países.

Pensar, portanto, desse ponto de vista é pensar a técnica de maneira mais ampla, é pensá-la como sistema, de forma a não reduzir o tema a uma simples evolução dos artefatos e tecnologias que foram sendo desenvolvidos pelos homens ao longo da história. Santos (1997:31), após uma digressão quanto à negligência das técnicas nos estudos geográficos, nos propõe: "a relação, que se deve buscar, entre o espaço e o fenômeno técnico, é abrangente de todas as manifestações da técnica, incluídas as técnicas da própria ação".

Nas palavras de Hughes (2008:101), os 'sistemas tecnológicos' incluem artefatos técnicos - turbinas, transformadores, organizações -, firmas industriais, empresas produtoras de energia, entidades financeiras e, não menos relevantes, artefatos jurídicos, leis que regulam seu uso. E, exatamente por isso, torna-se fundamental a ideia de sistema. A despeito das reflexões dos 
autores caminharem, em alguns momentos, de maneira distinta, a aproximação das duas proposições, do nosso ponto de vista, se torna profícua quando a ênfase é dada ao funcionamento sistêmico da técnica e suas implicações espaciais, pois a referência à técnica não é única e exclusivamente material, já que se configura como realização humana.

Não menos importante, do ponto de vista sistêmico, é a relação entre técnica e ciência. Observando a constituição do desenvolvimento técnico ao longo da história recente, sua profunda relação com o desenvolvimento científico é inegável, afinal "a técnica é uma aplicação da ciência" (ELLUL, 1968:6). Bernal (2007[1953]:393) demonstra tal fato quando descreve que o maquinário da revolução industrial nada mais foi do que a comprovação prática das novas energias descobertas pela ciência. O mesmo autor ainda segue mais radical afirmando que a ciência que se desenvolveu durante o século XIX perderia seu caráter acadêmico, para se converter em um dos elementos principais das forças produtivas. Já para Santos (1997:141) esse 'casamento' entre técnica e ciência é a versão atual da tecnociência que está situada na "base material e ideológica em que se fundam o discurso e a prática da globalização".

A inovação tecnológica é, em boa parte dos casos, o resultado desse 'casamento'. Porém, convém observar sua relevância quanto elemento difusor de informação e, portanto, de consolidação do poder. Inclusive, a própria questão da difusão da inovação foi o grande tema tratado pelo geógrafo sueco Torsten Hagerstrand, como apontou Santos (2003 [1979]:44), e um dos meios para o estudo de como a inovação fica gravada no espaço. Nesse sentido, um olhar renovado para a inovação tecnológica se faz necessário pela Geografia.

Deve ficar claro que toda inovação pressupõe um sistema de ações que geografizam ou não essas mesmas inovações, logo, trata-se de 'sistemas territoriais' já que pressupõem conteúdos políticos, econômicos, sociais e culturais. Silveira (1999:23) busca em Benno Werlen (1993) algumas elucidações no que diz respeito ao papel das ações na constituição do espaço geográfico: 
Compreendida a situação em que o agente se encontra, a ação se torna inteligível, isto é, adequada a esse instante na visão do agente. É por isso que a análise, continua Werlen, deve distinguir entre a situação vista pelo agente e a situação ela própria, e os elementos mais importantes da análise deverão ser os objetivos, a situação, a lógica e a explicação.

No caso da inovação tecnológica, como já ressaltamos, apesar do papel das empresas ser fundamental, inclusive para pensar o próprio sistema de ações, o Estado se configura como esse elemento importante de análise que observa Werlen. Principalmente na análise de questões que envolvem a Geopolítica.

Por ser um tema claramente vinculado às relações econômicas entre países, balança comercial, pauta de exportação, enfim, aquilo de que dependemos para nosso consumo e para nossas contas - aquilo que exportamos/importamos, pensarmos que o Estado é fundamental para o aprofundamento da dimensão territorial da política (COSTA, 2005:7).

Daí o famoso aforismo de que poderão existir povos e nações sem território, mas não há estado sem território. (...) Esse entrelaçamento entre os processos históricos de construção dos aparatos políticos nacionais com as estruturas materiais que lhes dão suporte e parte relevante da sua individualidade é a chave para desvendar as diversas faces dessa complexa relação.

Pretendemos dar ênfase a essa relação para compreender como a retomada das políticas de Estado no Brasil, em especial as industriais, a partir de 2003, e seus desdobramentos. Ou seja, a configuração dessas políticas como transformação da materialidade e dos conteúdos institucionais provoca transformações territoriais, gerando novas capacidades produtivas e, se efetivados os objetivos para os quais as políticas foram concebidas, seria possível amenizar nossa dependência tecnológica externa, elemento central de nossa geopolítica. 
No que se refere às discussões sobre a inovação, é de fundamental importância não perder de vista a relevância que o Estado vem tendo no atual período histórico técnico-científico e informacional (SANTOS, 1997), seja pela consolidação das políticas neoliberais da década de 1990, seja pela retomada de políticas mais voltadas ao desenvolvimento nacional verificadas na última década ${ }^{24}$.

Com a globalização, várias teorias recentes passaram a tratar de temas ligados ao fim do Estado e dos territórios. Muitas vezes pouco fundamentadas, essas teorias, como é o caso da estruturada por Ohmae (1999) e Badie (1995), têm questões superficiais que devem ser mais bem analisadas. $\dot{E}$

preciso antes de tudo distinguir o problema do fim do Estado do problema da crise do Estado de que tanto se fala nesses anos, com referência ou ao tema da crescente complexidade e à conseqüente ingovernabilidade das sociedades complexas, ou ao fenômeno do poder difuso, cada vez mais difícil de ser reconduzido à unidade decisional que caracterizou o Estado de seu nascimento a hoje.

(BOBBIO, 1987:126)

Apesar de Anderson (1993:25) ter um enfoque voltado às questões que tangem o nacionalismo, algumas reflexões importantes despontam do ponto de vista do Estado. O autor propõe haver quatro 'fantasias perigosas' no desenvolvimento da globalização: a primeira, de que estaria ocorrendo uma 'fragmentação' e 'desintegração' no mundo; a segunda, sobre a relação entre capitalismo, mercado e tamanho do Estado; a terceira, de que as 'corporações transnacionais' estariam deixando o nacionalismo obsoleto; e, por fim, que há "alguma conexão impenetrável entre capitalismo e 'paz', tal que o 'mercado livre' é intrinsecamente contraposto não só à economia de comando mas à guerra". A segunda fantasia parece ter elementos importantes nas reflexões que estamos estruturando neste momento. Se é verdade que países pequenos, ou seja, que teriam um tamanho pequeno, têm limitações políticas, como seria

${ }^{24}$ No capítulo 3 retomamos de forma mais aprofundada essa discussão, com base nas políticas de ciência, tecnologia e inovação no país. 
possível explicar os exemplos dados pelos Países Baixos, Finlândia, na Europa, e, melhor ainda, por alguns Tigres Asiáticos, como Coréia do Sul ${ }^{25}$ ? Nesses casos, segundo o autor, o senso de solidariedade nacional acaba por facilitar aos líderes políticos e econômicos o desenvolvimento de relações industriais mais suaves e a busca por nichos especializados, na divisão internacional do trabalho.

É claro que, de nenhuma forma, pretendemos que essa discussão promova uma visão do Estado mais pura, única e exclusivamente ligada à defesa dos interesses dos cidadãos e do bem-estar social. O que se pretende é enfatizar o papel do Estado como ente que interfere na economia, capaz ou não de promover políticas de defesa dos interesses nacionais, como saúde e defesa, contra as teses desenvolvidas pela escola do Estado mínimo.

Harvey (1992[1989]:118) alerta que a intervenção estatal é necessária para compensar falhas de mercado, evitar monopólios, fornecer bens coletivos, que por alguma incorreção não estão sendo fornecidos para a coletividade, enfim, que "as pressões coletivas exercidas pelo Estado ou por outras instituições (...), aliadas ao exercício do poder de domínio de mercado pelas grandes corporações (...), afetam de modo vital a dinâmica do capitalismo". Wallertein (2002:110) também compartilha desse apontamento. Nas palavras dele, a economia-mundo capitalista necessita de uma estrutura com Estados soberanos desempenhando ações cruciais no apoio aos empresários, assim como para garantir assunção dos custos de produção e garantia de quasemonopólios. Ou seja, não é negar que há ingerência por parte das grandes corporações, mas também não é dizer que, com o poder exercido por elas nas últimas décadas, os Estados nacionais perderam completamente importância.

$\operatorname{Mann}^{26}$ (2005[1997]:114) realiza um importante esforço no sentido de suavizar as críticas sobre o declínio ou enfraquecimento do poder estatal no período da globalização. O autor vai buscar nas teses de pós-modernistas

\footnotetext{
${ }^{25} \mathrm{O}$ papel do Estado na formação das políticas de industrialização na Ásia e, em especial, no caso da Coréia do Sul, foram analisado nos estudos de Wade (1990) e Amsden (1989).

${ }^{26}$ As reflexões de Michael Mann não se resumem ao período da globalização. Para o aprofundamento da estruturação do pensamento sobre o poder e autonomia do Estado, ver Mann (2005[1984]).
} 
como Baudrillard, Loyotard, Harvey, Taylor, Giddens, entre outros, a argumentação, julgada por ele excessiva, da debilidade, da marginalização do Estado-nação. A partir dessa crítica, Mann (idem) identifica alguns aspectos contrários a essas posições. Em primeiro lugar, para ele é inegável o papel das transformações em escala global das relações transnacionais dadas pelas relações tecnológicas e sociais do capitalismo, porém não se pode afirmar que há um singular universalismo desses aspectos. Segundo, um network global seria apenas uma modesta parte das particularidades dos Estados-nações, sendo os aspectos intrínsecos aos países, elementos fundamentais de análise. O que, por sua vez, explicita uma visão mais cautelosa sobre as teses alarmistas do fim do Estado, na globalização.

Outro ponto de vista em relação à globalização é dado por Fiori (2007a). Este autor ressalta o cuidado que devemos ter para pensar essa relação da globalização e o fim dos Estados, ou diminuição de seu papel, com o discurso do fim das fronteiras. A crise vivida pelos países desenvolvidos na década de 1970, em especial os Estados Unidos, acabou por desdobrar um movimento político-econômico conservador, facilitado pelas novas tecnologias da informação, no qual "sua verdadeira direção e seu significado foram dados pelas opções estratégicas e econômicas de algumas poucas potências" (idem: 77). Esse movimento ficou evidenciado pelas políticas liberalizantes que se expandiram não só nos países europeus, como nos países latino-americanos, com ideário neoliberal. Mas o mesmo autor aponta também que "quando se olha para a história de mais longo prazo, a constatação a que se chega é que ocorreu no século XX a universalização e não a morte dos Estados nacionais" (op. Cit.). Afinal temos hoje cerca de 190 Estados territoriais pelo mundo, reconhecidos pela Organização das Nações Unidas (ONU).

Shaw (2005[1997]:399) também é outro autor que questiona as teses do enfraquecimento do poder estatal. Segundo ele, não se pode confundir globalização com liberalização do mercado. Globalização deve, isso sim, ser definida como um conjunto complexo, porém articulado, de processos econômicos, culturais, sociais e, também, político e militar. No caso da crença relacionada a uma governança sem Estado, já que a regulação perpassa 
através dos organismos internacionais, da sociedade civil e dos próprios Estados, Shaw (idem:404) crê em um erro de análise, sobretudo pelo fato de haver, na divisão mundial do poder, diversos tipos de Estados, formas de governança e, inclusive, de poder estatal. Entre outros, Shaw (op. Cit.:412) exemplifica o que chamou de 'grandes centros independentes de poder estatal', formados por Brasil, Rússia, Índia e China, em que a atuação estatal, de forma alguma pode ser comparada à de países africanos, por exemplo. Ou seja, há uma gama de fatores e situações que demonstram um processo bem mais complexo do que a simples constatação de que o Estado enfraqueceu.

Quando observamos a capacidade de exercício da soberania ${ }^{27}$, aí sim temos diferenciais que merecem toda a atenção e que não eximem a importância das fronteiras e dos Estados territoriais. Wallerstein (2002:94) afirma que nenhum Estado moderno jamais foi soberano inteiramente de facto, pois sempre houve alguma resistência interna à sua autoridade. Já para Fiori (2007:78), a soberania não pode ser confundida com uma capacidade absoluta de poder. Ela sempre foi "objeto de conflitos e negociações que redefiniram seu significado e sua extensão várias vezes, através do tempo e dos espaços geopolíticos mundiais". Ou seja, não é uma jurisdição que se demonstra homogênea e nem fronteiras que têm significados iguais para todos os países. Ao contrário, Santos (1997) alerta que cada vez mais as fronteiras se tornam

\footnotetext{
${ }^{27}$ Como a análise teórica da tese está centrada nos elementos geopolíticos que constituem o fundamento da defesa de determinados interesses nacionais, optamos por não enfatizar conceitualmente a noção de soberania, seus usos e debates, apesar da importância reconhecida da teoria de Bodin, como explicitado por Barros (2001). Este autor pontua que "o conceito de soberania desempenhou um importante papel na afirmação dos princípios da territorialidade da obrigação política, da impessoalidade do comando público e da centralização do poder" (idem:23). Segundo Barros, Bodin foi o primeiro a realizar uma exposição sistemática da soberania, sendo suas obras Método para a fácil compreensão da história (1566) e Os Seis Livros da República (1576) suas principais referências. É interessante notar que Bodin, a partir de uma reflexão do direito público, procurou enfatizar a necessidade de que "cada sociedade deve ter seu próprio ordenamento jurídico, por causa de suas características específicas: leis e instituições boas para um povo pode ser um desastre para os outros" (op. Cit::119). O poder de cada sociedade política, para ser soberano, deve ser perpétuo e absoluto, porém Bodin diferencia o soberano da soberania de modo a esclarecer que "aquele que assume o poder, mesmo que seja absoluto, por um certo tempo, não pode ser considerado soberano (...)" (op. Cit::234-235). Por fim, deve ser considerado como o conceito que "reúne todos os elementos que compõe a República, dando-lhes unidade e coesão (...)" sendo o verdadeiro fundamento da comunidade política (op.Cit.:299). É exatamente por uma ligação muito forte, que apreciamos agora, com os elementos jurídicos e com a ideia de exercício do poder, dado pelo soberano, que julgamos não pertinente ao presente estudo sua utilização em termos teóricos tão rígidos e sim como a capacidade de executar ações estatais mais próximas às necessidades efetivas de um país.
} 
rígidas para um conjunto de países e porosa para outros, o que, por sua vez, torna mais complexa uma abordagem teórica baseada no conceito de soberania. É nesse sentido que se torna necessária a discussão das questões relativas às novas formas de governabilidade, ao conceito de soberania, ao papel dos Estados na globalização e à noção de 'porosidade territorial' ${ }^{28}$.

Santos (2004[1979]:161) em uma interessante reflexão sobre o Estado, naquele período de políticas desenvolvimentistas, enumera, primeiro, as formas de atuação tradicionais dos Estados à época, bem como: proteção e incentivos de monopólios, financiamento às grandes firmas, dotação de infraestrutura, formação profissional, promoção de indústrias de base, entre outras. Apesar disso, o que o autor aponta é que a crescente monopolização de grandes firmas acaba por gerar poderes que passam a minar as importantes funções do Estado, impossibilitando-o de corrigir imperfeições no sistema, (idem:175).

Antas Jr. (2005:138) corrobora essa opinião quando analisa o papel do direito no processo de reformulação do sistema capitalista, sobretudo o papel das multinacionais na formulação das normas de maneira a tirar melhores proveitos dos territórios nacionais. O mesmo autor utiliza um importante exemplo que foi a privatização do setor elétrico no Brasil, que, apesar de ter ocorrido nos anos 1990, nos serve de exemplo. Além da criação de agência reguladora para o setor, no Brasil verificamos que as consultorias utilizadas para a privatização foram, em grande parte, beneficiadas pelo BNDES ${ }^{29}$. Este banco, que, por sua gênese, deveria estar voltado para financiamentos direcionados ao desenvolvimento nacional, na época favoreceu grandes grupos internacionais de consultorias, como é o caso da Espírito Santo Centrais Elétricas (Escelsa), em 1995, que obteve consultoria da Deloitte, empresa britânica (FARIAS, 2008:89).

\footnotetext{
${ }^{28}$ Arroyo (2001:59) define porosidade territorial "como a qualidade que têm os territórios nacionais de ampliar ou aprofundar sua vinculação com o exterior, a partir do desenho de uma base normativa, formada por um conjunto de ações cuja intencionalidade é a inserção externa dos territórios".

${ }^{29}$ Ver Silva e Farias (2008:105).
} 
O exemplo das privatizações é de suma relevância, pois enfatiza um período marcado por uma ingerência ainda muito grande das multinacionais nos países subdesenvolvidos. Contudo, para mais além do papel das multinacionais, é claro que há uma nova configuração do poder dos Estados de que outras instituições fazem parte. Deste ponto de vista, Costa (2005:44), quando reflete sobre as transformações na esfera da governança, pontua que não podemos imaginar um "sistema no qual os estados fossem alijados ou substituídos por outras organizações públicas ou privadas, ou mesmo submetidos a um hipotético 'governo mundial'”.

O cerne da questão é que o Estado continua sendo o ator extremamente relevante, tanto na política nacional como na internacional. O que não nos permite entender o período mais afinco das políticas neoliberais como um momento de transição completa para uma governança sem Estado e com um poder ilimitado das multinacionais.

Ao contrário, temos visto algumas mudanças em curso que nos levam a repensar políticas unicamente baseadas na hegemonia das grandes empresas multinacionais. É nesse sentido que a defesa e a consolidação das empresas brasileiras, com a efetivação das políticas industriais e tecnológicas, seguem na contramão da tradicional conformação de um 'espaço nacional da economia internacional', proposto por Santos (1997:194), exatamente naquele sopro do neoliberal, sobretudo nos países em desenvolvimento. Ainda que os sistemas técnicos e o domínio da informação sejam utilizados pelas grandes firmas multinacionais, a defesa dos interesses nacionais na questão tecnológica tem ficado clara, inclusive na transformação da legislação brasileira para a defesa de conteúdos nacionais, ponto que será melhor analisado na segunda parte da tese. E esse é um novo dado do período atual.

Em relação à análise temporal, daremos ênfase à constituição do meio técnico-científico e informacional no Brasil, pautado, em um primeiro momento, na consolidação de um sistema de ciência e tecnologia, com foco na Financiadora de Estudos e Projetos (FINEP) para depois chegarmos a um sistema nacional de inovação. 
Do ponto de vista empírico, pretendemos elucidar essa questão com análises dos mecanismos financeiros e legais que têm entre seus objetivos o desenvolvimento de tecnologias produzidas por empresas nacionais e a consequente diminuição da dependência externa. Como se tratam de políticas ainda recentes, alguns resultados não são tão claros como se esperava. Mas a presença, nos mecanismos legais e de financiamento, da defesa dos interesses nacionais é um elemento que merece atenção e acompanhamento de resultados.

Por se tratar de um tema tradicionalmente contemplado pela economia, engenharia e sociologia, o trato metodológico da inovação nos levaria à simples importação dessas teorias. Suas principais questões devem ser tratadas, até pelo fato de não fazer sentido uma análise do tema sem suas próprias visões. Porém, pretendemos dar força ao conceito de inovação tecnológica dentro da disciplina geográfica, mais especificamente como eixo elementar do pensamento geopolítico, justamente a reflexão que realizaremos no próximo capítulo. 


\section{CAPÍTULO 2. Geopolítica e Inovação Tecnológica: uma Reflexão}

Necessária

\subsection{Questões sobre a negligência da Geopolítica}

A defesa dos interesses nacionais, assim como possíveis conflitos que decorrem dos sistemas de inovação, nos levam a pensá-lo como um importante aspecto estrutural da geopolítica. Ainda que, teoricamente, esse campo não seja diretamente tratado nas discussões sobre inovação tecnológica, pretendemos defender a ideia de que as políticas de fortalecimento do sistema nacional de inovação têm conteúdos geopolíticos fundamentais e esse prisma não é devidamente abordado.

Vários geógrafos brasileiros vêm ressaltando a necessidade de uma revisão urgente da Geopolítica e da Geografia Política; podemos citar Wanderley Messias da Costa (1992; 1999; 2005a), Berta Becker (1988; 1991), Lia Osório Machado (1993; 2011), Iná Elias de Castro (2005) e Márcio Cataia (2001).

O tema da Geografia Política e da Geopolítica, apesar de amplamente discutido na disciplina geográfica, manteve-se de certa forma estagnado ao longo de muitos anos, por estar, na maior parte dos casos, associado às políticas imperialistas com base nas ideias precursoras de Friedrich Ratzel.

O nascimento dessa corrente geográfica, em um contexto de surgimento dos Estados-Nações e de imperialismos, que marcaram o século XIX e o início do $\mathrm{XX}$, acabou por criar linhas bastante voltadas a políticas externas e internas muito conservadoras e ligadas a governos autoritários e radicais, como foi o caso emblemático da participação do General Karl Haushofer nas políticas da Alemanha nazista. 
Retomando inúmeros conceitos ratzelianos, tal como o do Lebensraum (espaço vital) e os dos geógrafos americanos e britânicos (como Mackinder), o general geógrafo Haushofer (1869-1946) dá, em seguida à Primeira Guerra Mundial, um impulso decisivo à geopolítica. Sem dúvida, numerosos geógrafos considerarão que é a última incongruência estabelecer uma aproximação entre sua geografia 'científica' e o empreendimento do general, estreitamente ligado aos dirigentes do Partido Nacional-socialista.

(LACOSTE, 2006[1986]:24)

Sanguin (1977:39) também ressalta esse apontamento, quando relembra a importância da doutrina do espaço vital no III Reich nazista, ou mesmo na Itália de Mussolini, em que a política do Estado trabalhava a serviço das conquistas territoriais. Conquistas, essas, que já não se restringiram ao nazismo, mas que vinham ocorrendo desde a expansão européia pela África.

Portanto, não é coincidência nem pecado original que o status acadêmico da geografia tenha institucionalizado um conhecimento útil, para revelar, controlar e dominar territórios, para fazer a guerra, bem como para desvendar riquezas ocultas nas terras distantes que alimentaram as aventuras comerciais coloniais e imperialistas dos séculos XIX e XX. Afinal, todas as ciências participaram desta aventura (...).

(CASTRO, 2005:43).

Seguindo esse raciocínio, Lacoste (2006[1985]:24) relembra que a "geopolítica hitleriana foi a expressão, a mais exacerbada, da função política e ideológica que pode ter a geografia”. O que fez o próprio autor mencionar que de "1945 para cá, não é mais de bom tom fazer referências à Geopolítica" (idem). Deste ponto de vista, o "desprestígio da Geopolítica como ciência vem de sua apropriação pelos adeptos do Gen. Karl Haushofer que, depois do advento de Hitler, (...) transformaram a Geopolítica em um pretexto científico para justificar as teses do expansionismo nazista" (MATTOS, 1975:4). Para Moodie (1965:18), a 'Geopolitik' ${ }^{30}$ prestou um desserviço ao pensamento

${ }^{30}$ Moodie (idem:17) usa o termo 'Geopolitik' para fazer referência ao uso daquele conhecimento que vinha sendo desenvolvido pela Alemanha, Itália e Japão. "Sua perspectiva e 
político-geográfico, fato ainda mais lamentável por ter sido Ratzel o primeiro entre os escritores modernos a estudar a Geografia Política em normas científicas. Porém, essa questão é muito mais profunda que as críticas atribuídas a ela.

Ainda no período de vigência do nazismo, um refugiado alemão nos EUA passou a estudar de forma muito aprofundada as raízes das teorias ligadas à Geografia Política e à Geopolítica. Hans Werner Weigert foi quem escreveu uma das melhores resenhas sobre os escritos de Haushofer, suas relações com o nazismo e sua importância no pensamento geopolítico ${ }^{31}$. Para Weigert (1963[1942]:19) um artigo publicado na revista The Reader's Digest sobre os cientistas que estavam por trás de Hitler fez com que se tornasse aberto ao público comum o uso do conhecimento de Haushofer pelo estadista da Alemanha ${ }^{32}$. Entre os trechos do artigo citados por Weigert, consta que o 'Dr, Haushofer e seus homens dominam o pensamento de Hitler'.

No ano seguinte, 1942, foi a vez de a revista Time Magazine fazer sua parte publicando um texto no qual havia uma apologia à instauração de uma disciplina geopolítica nas escolas americanas. Novamente era dada ênfase ao papel de Haushofer, como aquele que tornou possíveis as vitórias de Hitler 'na política do poder e na guerra' e, por isso mesmo, deveria ser estrutural nas

\footnotetext{
literatura eram inteiramente subjetivas e representavam uma prostituição dos métodos e resultados da Geografia Política". Já Sanguin (1977:9) define o termo como uma pseudociência que colocou a geografia a serviço do da política e da conquista territorial que, lamentavelmente, ganhou força no holocausto hitleriano.

${ }^{31}$ Segundo Weigert (1963[1942]:84) Haushofer participou como general e professor da universidade de Munich. Suas atividades estavam, inclusive, nos meandros das intrigas internas do partido e no círculo próximo de Hitler.

${ }^{32}$ Para Miyamoto (1981:44) essas críticas foram tardias, já que a escola possibilista francesa havia avançado muito em relutar contra a base organicista e determinista da Geopolítica. Um exemplo claro pode ser observado nos escritos de Camille Vallaux (1914:5). O geógrafo francês postulava que a concepção de Estado-organismo mais se prestava a aproximar as ciências sociais dos grandes êxitos das ciências biológicas, do que a produzir uma teoria efetiva do Estado. Vallaux (idem:7) afirma que o estágio em que se encontravam essas disciplinas ainda era muito rudimentar e, por isso mesmo, incorreria em grave erro qualquer confusão entre os métodos de cada uma delas. Por outro lado, Vallaux rechaçava a grande influência do meio que se colocava à frente do pensamento geográfico da época: " $\mathrm{y}$ em el espacio, el hombre muestra tal potencia de adaptación al medio, cualqueira que sea, que parece que el medio natural es impotente para determinar los destinos de la sociedad política (...)" (op. Cit.: 10). O fato é que, Myamoto (idem) parece não ter observado o verdadeiro ponto onde Weigert queria chegar: não era a crítica à teoria e sim o fato de ter chegado ao conhecimento da população a influência de um dado tipo de conhecimento científico na política de Hitler, ou seja, a Geopolítica.
} 
estratégias dos EUA. Segundo Weigert (idem), a tendência dessas exaltações haushoferianas não só beirava o ridículo como também fez com que houvesse um reforço de que os estudos geopolíticos de Haushofer fossem parte de base das maldades nazistas criando, assim, um erro: o de que a Geopolítica era um monopólio nazista.

Um parêntese necessário aqui diz respeito aos próprios escritos de Haushofer. Em um artigo publicado no ano de 1948, no livro de Edmund Aloysius Walsh Total Power: a footnote to history, Haushofer (2006[1948]:55) se defende de maneira visceral contra as acusações sobre sua participação junto a Hitler. Segundo ele próprio, quando foi requisitado para fazer uma revisão do Mein Kampf, negou, sob a justificativa de que o livro do líder nazista nada tinha de Geopolítica. Mais ainda, argumenta nunca ter encontrado Hitler sozinho e que, no último encontro, cuja motivação não é clarificada no artigo, entrou em desalinho público com Hitler, tendo, a partir de então sua vida mudada radicalmente. Em relação às suas aspirações, no artigo fica clara a defesa de que a Geopolítica alemã está muito próxima da Geopolítica americana, ou seja, de uma Geopolítica capaz de prevenir catástrofes, como a Primeira Guerra Mundial, com base na ideia de que os povos e suas potencialidades de desenvolvimento deveriam se pautar nas suas raízes culturais, assim como as minorias poderiam ter os mais altos sensos de justiça e autonomia cultural e política.

De qualquer forma, essa relação tão visceral entre a Geografia Política e os governos autoritários e imperialistas não pode nem deve diminuir sua importância, assim como eximi-la de uma análise mais apurada, como sugeriu Claude Raffestin (1980:19):

É evidente que, com o aparecimento da geopolítica, estamos lidando com uma ciência do Estado, concebido como um organismo geográfico em constante movimento. É o jogo sem vencedores dos Estados do século XX que começa. Nos anos 30, uma série de autores, sob a direção de Karl Haushofer, elaboraram o pensamento geográfico do Estado nazista, utilizável por qualquer Estado totalitário. Desde então, a geopolítica aparece como uma geografia aplicada ao Estado. 
Como estranhar depois do desinteresse de certas escolas pela geografia política, tida nessas condições de má fama? Golpeada assim, de forma tão vil, a geografia política permaneceu estacionária durante um longo tempo. Ainda que essa geografia não fosse justamente, em nossa opinião, uma verdadeira geografia política mas uma 'geografia do Estado.

Ou seja, os fundamentos teórico-metodológicos, presentes no desenvolvimento da Geopolítica, fizeram parte de um momento histórico e, por esse fato, devem ser resgatados não de forma restrita e sim considerando as profundas transformações mundiais, principalmente das últimas três décadas, como a revolução das tecnologias da informação, a proliferação das multinacionais e o fim da Guerra Fria.

Para que tenhamos um panorama do desenvolvimento mais específico da Geografia Política e da Geopolítica, faremos, a seguir, um resgate dos principais autores e de suas contribuições, a começar por clássicos mundiais, passando pelos autores brasileiros que tiveram grande influência no pensamento geográfico brasileiro, para então realizar a defesa de sua revisão com acepção à inovação tecnológica.

\subsection{Perspectiva histórica da Geografia Política e da Geopolítica}

Iniciando essa retomada pelas reflexões de Friedrich Ratzel (1987), alguns apontamentos se tornam necessários. Quando convidado para escrever o prefácio da obra La Géographie Politique. Les concepts fondamentaux, Michel Korinman inicia seu texto relembrando tanto o papel que os trabalhos cartográficos tiveram no sucesso da Alemanha na Guerra Franco-Prussiana (1870), quanto na multiplicação das cadeiras de Geografia decorrentes dela naquele país. Afinal, Ratzel não começa seus estudos pela Geografia e sim pela Farmácia, passando pela Zoologia e, só mais tarde, dá atenção aos estudos geográficos. Segundo Korinman, dois fatores são fundamentais para 
sua conversão em geógrafo: seu nacionalismo e uma viagem aos EUA. A partir de então, Ratzel passa a dedicar seus estudos à Geografia, tornando-se professor em Munich. Por ter participado da guerra, suas ideias voltadas à aplicação da ciência geográfica na política surgem quando se torna membro fundador do Comitê Colonial na Alemanha, enfatizando aos dirigentes do Partido Nacional Liberal, do qual fazia parte, a necessidade de, no Congresso de Berlim (1884-1885), pensar a nova colonização com base científica.

Como mencionamos no parágrafo anterior, Ratzel dedicou-se, previamente, à Farmácia e à Zoologia, assim, em toda a sua obra, é inegável o uso de abordagens organicistas para a explicação da Geografia Política. Um exemplo irrefutável disso pode ser dado quando ele menciona que o grupo familiar "é e permanece um organismo monocelular; o Estado, ao contrário, atrai para o seu círculo de ação um número sempre mais considerável desses organismos elementares e ultrapassa a todos" (RATZEL, 1983[1898-1899]:97). Mais além, também poderíamos citar sua afirmação de que o estado se constitui como um organismo ligado a uma fração localizada da superfície terrestre (RATZEL, 1987[1897]:61). Para a consolidação de sua teoria, Ratzel (idem:64) propõe que, assim como na ordem animal ou vegetal, o organismo mais perfeito é aquele em que as partes sacrificam sua independência visando o todo e, deste ponto de vista, o Estado seria um organismo imperfeito. Também, era recorrente em seus textos estabelecer reflexões ligadas a analogias e métodos matemáticos para a explicação desse fenômeno novo na história mundial, fato que o fez "eliminar de seu método de análise todas as contradições sociais, da mesma maneira que faz a lógica matemática" (CATAIA, 2001:33), o que não anula a sua importância teórica, como ressaltou Becker ${ }^{33}$ (1988:99).

Pensar o Estado, pois, foi um dos focos centrais de análise ratzeliana e, mais profundamente, sua relação com o solo. Ratzel (1983[1898-1899]:93), em primeiro lugar, afirma que o "Estado não é concebível sem território e sem fronteiras", para depois proferir a máxima: "Estado não pode existir sem um

\footnotetext{
33 “A Geografia Política, de Ratzel (1897), representou, sem dúvida, um avanço na teorização geográfica do Estado. Ratzel foi um dos poucos geógrafos a assumir explicitamente o valor estratégico do espaço e da Geografia".
} 
solo". A partir desse pensamento é que Ratzel desenvolve seu campo de análise, incluindo leis gerais. No nosso caso, a questão de pensar o Estado estrategicamente, a partir de sua relação com o território, é o eixo fundamental. Afinal, com o passar dos anos, cada vez mais foram surgindo geógrafos que passariam a aplicar o pensamento estratégico no corpo da burocracia estatal de seus países.

A tarefa do Estado, no que concerne ao solo, permanece sempre a mesma em princípio: o Estado protege o território contra os ataques externos que tendem a diminuí-lo. No mais alto grau da evolução política, a defesa das fronteiras não é a única a servir esse objetivo; o comércio, o desenvolvimento de todos os recursos que contém o solo, numa palavra, tudo aquilo que pode aumentar o poder do Estado a isso concorre igualmente.

(RATZEL, 1983[1898-1899]:96)

É primordial notar que suas análises das relações entre Estado e solo, no final do século XIX, representaram uma corrente de pensamento inserida em um momento de formação dos Estados europeus e de criação das fronteiras $^{34}$. Ou seja, havia uma clara preocupação de pensar o território e os aspectos ligados à atuação estatal em relação a sua defesa e desenvolvimento.

Paralelo ao pensamento de Ratzel, surge a figura de Rudolf Kjéllen (1864-1922). Sua importância está no fato de Haushofer, articulando suas ideias com as de Ratzel, ter feito emergir uma Geopolítica aplicada à realidade alemã (COSTA, 2010[1992]:118). A formação de Kjéllen era na Ciência Política, o que o fez concentrar seus esforços sobre as teorias do Estado e, como aponta Tosta (1984:14), investigar sobre "o que deve ser o Estado". Observando um abandono, por parte dos cientistas políticos, em relação aos geógrafos, Kjéllen observa cinco elementos fundadores do Estado: território; povo; economia; sociedade; e governo (idem:17). Assim surge o termo Geopolítica, que respondia às suas aspirações sobre as relações entre Estado

\footnotetext{
${ }^{34}$ Foucher (1991:100) ressalta que, apesar da maioria das fronteiras atuais terem sido criadas após a Segunda Guerra mundial, na Europa esse fenômeno já vinha ocorrendo desde a metade do século XIX e se acelera com a Primeira Guerra Mundial.
} 
e território, por muitas vezes recorrendo a reduções biologicistas e organicistas $^{35}$ (COSTA, 2010[1992]). Em nenhum momento Kjéllen deixou dúvidas "quanto ao caráter estreito, reducionista e expansionista de sua concepção de Estado e dos objetivos de sua 'nova ciência', intencionalmente dirigida aos 'estados-maiores' dos impérios centrais da Europa, em especial a Alemanha" (idem:56).

Essa base, ou seja, "um receituário explícito do imperialismo" (op. Cit.:57) vai servir para o desenvolvimento das ideias de Karl Haushofer que, com sua obra De la Geopolitique transformou a Geopolítica em uma verdadeira máquina política a serviço dos Estados, porém, pensar estrategicamente o estado, sua expansão e consolidação territorial foi muito além de Haushofer, produzindo uma vasta gama de estudos e aplicações práticas.

A começar por Mackinder, essa história revela diversos pormenores. Ó Thathail (2006:17) nos recorda que Mackinder, professor de Geografia em Oxford desde 1887, aparece no contexto geográfico britânico como um verdadeiro 'desbravador', tanto de outras localidades quanto da própria evolução do conhecimento geográfico. Isto porque, junto à Royal Geographical Society, promoveu uma expedição ao Kenya que Ihe deu inspiração para pensar que o conhecimento geográfico poderia salvar o império britânico do declínio - para ele, visível. No seu clássico texto The Geographical Pivot os History, as reflexões fortemente calcadas em uma visão estratégica do espaço são notórias.

Em primeiro lugar, podemos observar uma clara alusão aos entraves e favorecimentos do meio natural, pensados a partir do posicionamento da Rússia, quando o autor menciona que, em função de suas características climáticas, temos ao norte florestas permeadas por pântanos e, ao sul, áreas mais secas com a presença de planícies (MACKINDER, 1967[1904]:109),

\footnotetext{
35 "Comparando o Estado com um ser vivo, Kjellén multiplicou-o numa série de analogias: o território seria o corpo, a capital representaria o coração e os pulmões, as vias de transporte corresponderiam às artérias e às veias, os centros de produção seriam as mãos e os pés. Segundo ele, o verdadeiro poderio do Estado resulta da existência de três condições essenciais: a) grande espaço; b) ampla liberdade de movimentos; c) perfeita coesão interna" (AZEVEDO, 1955:45).
} 
fatores físicos que estão presentes nos estudos geopolíticos, incluindo os clássicos brasileiros.

Em um segundo momento, passamos a observar claramente a questão estratégica quando ele define a área pivô, que, mais tarde, em 1919, passaria a ser chamada de Heartland (MELLO, 1999:45). Nessa área estratégica, definida após uma longa explanação justificativa sobre a centralidade que abarcaria a Rússia e dificultaria influências marítimas, é que podemos notar o caráter estratégico de seu pensamento:

The oversetting of the balance of power in favour of the pivot state, resulting in this expansion over the marginal lands of Euro-Asia, would permit of the use of vast continental resources for fleet-building, and the empire of the world would then be in sight.

(MACKINDER 1967[1904]:118).

Pensando a Geografia Política como uma ciência aplicada, Mackinder, que viveu o grande momento de formação dos Estados territoriais europeus, marcou sua posição como aquele que, em sua obra, se engajou em um pragmatismo e em um senso formador de opinião sobre as questões estratégicas do território, que foi utilizado, inclusive, por Haushofer, situado em campo oposto ao dele (COSTA, 2010[1992]:77). Seu pragmatismo foi exatamente no sentido de "aliar à análise política do equilíbrio de poder do quadro internacional os elementos empíricos (para ele concretos) fornecidos pelos estudos correntes produzido pela geografia" (idem).

A despeito de essa visão estrategista ter sido criticada nos EUA ${ }^{36}$, este país não fugiu à regra e também teve geopolíticos com teorias fortemente

\footnotetext{
${ }^{36}$ Bowman (2005[1942]) faz uma crítica incisiva quanto o caráter imperialista e não científico praticado, sobretudo, pela Alemanha com Haushofer. Com um discurso de defesa da democracia, o autor afirma que não há possibilidade de diálogo com uma ideia de Estado como organismo, governado por leis científicas e regras aplicadas por um ditador (idem:69). Outro exemplo pode ser dado por Hartshorne (1950:97). Este autor defende veementemente a Geografia Política e sua evolução como ciência. Procurando estabelecer os nexos de
} 
calcadas no militarismo, sendo Nicholas Spykman seu maior expoente. Este autor ganhou notoriedade com dois artigos publicados na The American Political Science Review e com dois livros, um publicado em vida e outro póstumo. Foi professor de Relações Internacionais na Universidade de Yale e teve uma morte prematura, com apenas 49 anos. Na introdução de seu livro, Francis Sempla relembra que o autor, durante a década de 1930, passou a dar muita importância aos fatores geográficos como enlaces centrais de uma política de defesa norte-americana. À época, Spykman acreditava que a política de defesa daquela nação era 'irrealista e inadequada', fato que o fez publicar um artigo sobre as nuances entre política externa e Geografia. Daí, provavelmente, a explicação para suas análises de caráter estratégico quanto às ações que os EUA deveriam tomar, tendo em vista a configuração antes e durante a II Guerra Muldial ${ }^{37}$.

Em relação ao seu pensamento, é inegável que Spykman tenha tido nas ideias de Mackinder parte de suas reflexões, porém com alterações significativas. A noção de Heartland foi por ele aprofundada no sentido de dar ênfase não apenas à necessidade de controlá-lo, como também de cercá-lo. Essa área de cercamento, o autor denominou Rimland. Spykman discutiu a necessidade de manter relações estratégicas, no pós-guerra, com a Alemanha e o Japão, como força capaz de conter o crescimento soviético. Fato mais curioso e diretamente relacionado ao Brasil, foi a importância que esse geopolítico deu à América do Sul na configuração da defesa dos interesses americanos.

Spykman (2007[1942]:3) inicia seu livro consubstanciando o poder crescente que os EUA foi adquirindo durante a I Guerra Mundial e como isso levou ao consequente ataque a Pearl Harbor. Já ficava evidente sua visão de que o crescente poder americano deveria ser seguido de estratégias claras de defesa e manutenção de espaços essenciais a garantir esse poder, incluindo aí a escolha por uma opção 'intervencionista' ou 'isolacionista'. Para pensar de

investigação e afastá-los do que denomina 'conceito enganador' do estado como organismo, entre outros, e das consequências desastrosas dessa 'pseudociência' para a ação política.

${ }^{37} \mathrm{Em}$ parte isso explica o titulo dado ao autor da introdução, Sempla: "A Geopolítica Realista de Nicholas Spykman". 
forma mais aprofundada a questão da ação norte-americana, dividiu sua obra em duas grandes partes: uma voltada aos EUA e ao balanço do poder; e uma segunda intitulada 'A luta pela América do Sul'. Esta última talvez seja a que mais impressiona do ponto de vista de sua racionalidade estratégica levada ao extremo ${ }^{38}$.

Enfim, se observados com maior atenção, esse grupo de geopolíticos supracitados acabaram provocando uma verdadeira aversão ao pensamento geopolítico. Ó Tuathail (1998:3) exprime muito bem o que vieram a ser esses 'experts' em geopolítica: eles não viam 'o real', mas sim suas interpretações e constructos da cultura geopolítica como 'reais'.

Nesse contexto, a ligação entre as teorias da Geografia Política e da Geopolítica acabou estigmatizada ${ }^{39}$. O desenvolvimento das ideias de Mackinder (1967[1904]), que apontavam a necessidade de uma visão mais 'global' do sistema político mundial, não diminuiu o desalinho da Geopolítica, inclusive por ter sido Mackinder um dos geopolíticos com visão fortemente estratégica e essa questão 'global' não foi o que ficou de suas reflexões. Por outro lado, Bowman (2005[1942]:68), crítico contumaz dessa Geopolítica a

${ }^{38} \mathrm{Um}$ resumo dessas ideias de Spykman sobre a América do Sul foi realizado por Fiori (2007b): "Ele parte de uma separação radical entre a América dos anglo-saxões e a América dos latinos. Nas suas palavras "as terras situadas ao sul do Rio Grande constituem um mundo diferente do Canadá e dos Estados Unidos. E é uma coisa desafortunada que as partes de fala inglesa e latina do continente tenham que ser chamadas igualmente de América, evocando uma similitude entre as duas que de fato não existe" (p. 46). Em seguida, ele propõe dividir o "mundo latino" em duas regiões, do ponto de vista da estratégia americana no subcontinente: uma primeira, "mediterrânea", que incluiria o México, a América Central e o Caribe, além da Colômbia e da Venezuela; e uma segunda, que incluiria toda a América do Sul abaixo da Colômbia e da Venezuela. Feita esta separação geopolítica, Spykman define a "América Mediterrânea como uma zona em que a supremacia dos Estados Unidos não pode ser questionada. Para todos os efeitos, trata-se um mar fechado, cujas chaves pertencem aos Estados Unidos. O que significa que o México, a Colômbia e a Venezuela (por serem incapazes de se transformar em grandes potências) ficarão sempre numa posição de absoluta dependência dos Estados Unidos" (p. 60). Donde, qualquer ameaça à hegemonia americana na América Latina deverá vir do sul, em particular da Argentina, do Brasil e do Chile, a "região do ABC". Nas palavras do próprio Spykman: "para nossos vizinhos ao sul do Rio Grande, os norte-americanos seremos sempre o 'Colosso do Norte', o que significa um perigo, no mundo do poder político. Por isto, os países situados fora da nossa zona imediata de supremacia, ou seja, os grandes Estados da América do Sul (Argentina, Brasil e Chile), podem tentar contrabalançar nosso poder através de uma ação comum ou através do uso de influências de fora do hemisfério" (p. 64). E, neste caso, conclui: "uma ameaça à hegemonia americana nesta região do hemisfério (a região do $A B C$ ) terá que ser respondida através da guerra". ( $p: 62)$ ".

${ }^{39}$ Fato que no Brasil também foi agravado pela existência de um período militar ditatorial, já que tivemos na nossa história a importância de estudiosos geopolíticos ligados a escolas militares, como Golbery do Couto e Silva e Carlos de Meira Matos, que serão devidamente abordados posteriormente. 
serviço dos estados imperialistas, reforçou ainda mais esse estigma quando afirmou que a Geopolítica apresentava uma visão distorcida das relações históricas, políticas e geográficas do mundo e suas partes.

O que parece elementar neste ponto da tese é entender como essas ideias acabaram sendo apreendidas e utilizadas no Brasil, o que, por sua vez, será feito a partir de uma sistematização do pensamento geopolítico no Brasil. Afinal, a "geopolítica encontrou caminho fértil deste lado do Atlântico, haja vista a rapidez com que se propagou" (MIYAMOTO, 1981:46).

Miyamoto (idem:50) salienta que é preciso dividir a produção de um pensamento geopolítico, das preocupações com questões geopolíticas. Estas, segundo a Escola Superior de Guerra, já eram visíveis "no terreno das incursões práticas" através de Alexandre Gusmão - responsável pelo Tratado de Madri, o Visconde de Rio Branco e o Barão de Rio Branco (op. Cit.). Já em relação à produção bibliográfica acerca da Geopolítica, Tosta (1958, apud Miyamoto, 1981:51) aponta que foi Backheuser o precursor e "quem começou a sistematizar informações e deu corpo para que essa disciplina se desenvolvesse em território nacional".

Quando Costa (2010[1992]:179) analisou o prisma da Geografia Política e da Geopolítica, no Brasil, chamou a atenção para a ausência de um verdadeiro campo acadêmico geopolítico no Brasil. Segundo o autor, o que houve foi uma "manipulação de alguns conhecimentos ditos 'geográficos' para a formulação de esquemas que interessem às políticas de poder", fato que o levou a afirmar que não "há no Brasil um pensamento geopolítico, (...), que possa ser referido como produto de um ambiente de reflexão acadêmico especificamente universitário". Ao contrário, "os estudos geopolíticos desde logo tiveram hegemonia do pensamento militar e das suas instituições". As análises que vêm a seguir corroboram tal máxima.

Partindo das contribuições de Delgado de Carvalho e Everardo Backheuser $^{40}$, a participação desses dois estudiosos teve influência

\footnotetext{
${ }^{40}$ Becker (1988:111) afirma que não "é, portanto, de admirar, que a Geopolítica brasileira remonte às décadas iniciais do Século XX, precedendo o estabelecimento da Geografia como
} 
fundamental na constituição dos cursos de Geografia no Brasil. Nas palavras de Ancelmo e Bray (2002:115), eles representaram "as duas principais vertentes epistemológicas da Geografia na década de 20. Os dois tiveram ativa participação na implementação da Geografia Moderna em termos de pesquisa e ensino". É importante salientar esse fato, já que suas contribuições na formação dos cursos de Geografia refletiram-se, mais tarde, em linhas de pensamento geopolíticas. Porém, aqui não vem ao caso a consecução de fatos que se sucederam na implementação da Geografia à época e sim quais foram os caminhos teóricos tomados por esses professores, que tanto influenciaram o desenvolvimento do pensamento geopolítico nacional.

No ano de 1948, Everardo Backheuser lança seu livro Curso de Geopolítica Geral e do Brasil. Já no prefácio, o autor explicita a função da Geopolítica, em sua concepção: deve servir à formação de estadistas, nas Faculdades de Ciência Política, em primeira instância, mas poderia, também, servir à Engenharia, ao Direito, à História e à Geografia, e às escolas técnicas do estado maior (idem:7). É, portanto, logo de início que seu caráter fortemente aplicado às funções do Estado resplandece. Na introdução, por sua vez, toda a base teórica se faz pautada em Kjellén, ou melhor, na

ousada renovação de valores científicos da Teoria Geral do Estado semeou o sábio escandinavo os fundamentos da nova sistematização da Ciência política em moldes objetivos, realísticos, quase se pode dizer concretos.

(op. Cit::13)

Após explanação sobre as apreciações da noção de Estado em Kjellén, o que Backheuser enfatiza é a passagem de uma noção de 'Estado Ideal', oriunda do liberalismo e, portanto, 'supervisor', para um Estado propulsor do

disciplina acadêmica, com os estudos pioneiros de Everardo Backheuser (1926), fortemente influenciado por Ratzel e as teorias orgânicas do Estado de Kjellen, e de Delgado do Carvalho (1929), pelo contrário, influenciado pela escola francesa de Vidal de La Blache". Porém, convém ressaltar que Delgado de Carvalho, quando escreve junto à Therezinha de Castro, afirma a importância da teoria de Ratzel (Carvalho e Castro, 1963:7), passagem que será abordada devidamente mais adiante. 
progresso, antes nas mãos da iniciativa privada. Ou seja, seu caráter centralizador das ações sociais e defensor do 'progresso'.

Tamanha filiação de Backheuser ao pensamento de Kjellén o faz recordar que, a despeito das duras críticas que o termo geopolítica sofreu após seu uso pelo estado nazista, ele mesmo, no ano de 1924, já havia escrito artigos na imprensa, assim como em 1924 no livro A Estrutura Política do Brasil. E é com base em Kjellén que Backheuser (1933) propõe os três grandes problemas geopolíticos do Brasil: seu grande espaço; sua capital; e a divisão territorial baseada na 'equipotência'. Segundo Backheuser (1948:48), essas "pequenas monografias são lídima aplicação ao Brasil de ensinamentos de ordem geral hauridos em Ratzel, Kjellén, Maull e tantos outros (...)”.

Contemporâneo de Backheuser, Mario Travassos também marcou pela relevância no desenvolvimento de suas ideias ligadas à Geopolítica. Em seu clássico livro Projeção Continental do Brasil, Travassos (1938:ix) revela um pensamento estratégico baseado na tendência de os Estados terem saídas para o mar e de "remontarem seu domínio por onde o trafego seja capaz de levá-lo", sendo essas questões estruturantes na compreensão da Geopolítica sul-americana. Desta forma, Travassos (idem:12) segue sua linha estratégica a partir de dois antagonismos: o Atlântico e o Pacífico; e as bacias Amazônica e do Prata. Os fatores que deveriam ser levados em conta para a Geopolítica, na região, seriam as vias de comunicação, os meios de transporte e as riquezas naturais. Vale ressaltar a preocupação sempre repetida em relação à Amazônia e à necessidade de integrá-la de forma mais ativa à economia brasileira e sulamericana.

Mais tarde, quando Travassos escreve o livro Introdução à Geografia das Comunicações, novamente a Amazônia aparece no centro da discussão. Segundo ele, a região seria uma "formidável realidade geográfica" de que o Brasil deveria se dar conta, sobretudo no que tange ao desenvolvimento econômico (TRAVASSOS, 1942:107). Porém, mais importante que a Amazônia, no caso desse livro, foi a ênfase dada pelo autor quanto à complexidade geográfica do tipo misto brasileiro, ou seja, de sermos um país, ao mesmo tempo, marítimo e continental. Após uma descrição física das características do 
território nacional, Travassos (idem:106) pontua o papel funcional das regiões brasileiras, sobretudo no que diz respeito às comunicações, como no caso da Amazônia brasileira ter saída para o oceano e a importância da ligação com o sul do continente. O Brasil, portanto, teria um potencial econômico e político a partir de sua expressão concêntrica na bacia do Prata, da força de atração na Amazônia e da capacidade coordenadora com o litoral do Atlântico, formando assim um 'Brasil Continental' (op. Cit.:110). Nessa teorização, Martin (2007:43) ressalta, em primeiro lugar, a relevância do pensamento de Mackinder, para estruturar a tese do poder terrestre como chave de uma nova projeção continental do Brasil; por fim, relembra que essa foi a base que influenciou o 'Plano de Aviação' do período varguista, ou seja, uma clara alusão ao uso das teorias geopolíticas brasileiras pelo governo federal.

Lysias Rodrigues também tem seu lugar de destaque nesta relação dos clássicos da Geopolítica brasileira. Seu célebre clássico Geopolítica do Brasil traz pelo menos duas grandes questões: o Brasil frente às grandes potências mundiais, ou seja, Estados Unidos, Inglaterra e Rússia; e a ocupação do território brasileiro, como elemento para se tornar potência.

Em relação ao primeiro ponto, é importante notar a forte acepção nacionalista de Lysias Rogrigues. Quando relembra o posicionamento das ideias de Spykman sobre a América do Sul, Rodrigues (1947:44) não vacila em pontuar que se os imperialistas norte-americanos pensam que a "principal área do continente sul-americano continuará a agir na política externa norteamericana (...) como um território transoceânico dos Estados-Unidos", eles "não só demonstram completo desconhecimento sobre essa área, cuja maior parte constitui o Brasil, (...) como ainda (...) andam fundamentalmente enganados com os povos que essa área principal do continente habitam". Finaliza o autor com a máxima de que o "Brasil, hoje, é potência em marcha (...)". Potência dada, sobretudo, pelo fato de termos uma imensa massa territorial, assim como a Rússia, os EUA e a China, e também por possuímos a costa marítima do Oceano Atlântico e o rio Amazonas (idem:50).

Quanto à organização interna do país, Lysias não esconde sua concepção unificadora da nação brasileira. Em passagem que o autor discorre 
sobre a importância do Estado Novo, além da exacerbação das saídas encontradas pelo governo para a impossibilidade de ligar nossa grande área via ferrovias e fios telegráficos, houve, também, 'uma centralização enérgica' desenvolvida pelo Governo Federal, "cortando certos regionalismos doentios, coibindo expansões políticas absolutas, estabelecendo uma só bandeira, a nacional, um só hino, o do país, sob, a mística soberana: 'Grande, só o Brasil!'” (op. Cit: :57).

Para Cataia (2006), a preocupação com a presença do Governo Federal nas áreas interioranas do Brasil, fez Rodrigues pensar em uma nova ocupação do território, baseada na melhor dispersão ecumênica e em uma nova divisão político-administrativa do interior do país. Afinal, "as fronteiras internas do Brasil constituíam-se num 'aleijão geográfico', pois muitos municípios da hinterlândia possuíam dimensões superiores a muitos estados federados, o que dificultava sua racional administração". Era preciso, portanto, "mobilizar a população e o Estado para transformar o Brasil num país continental e não somente um país ocupado em sua borda atlântica" (idem). Revelou, assim, toda sua postura centralizadora e estrategista no pensamento político nacional.

Outra personalidade que contribuiu em muito para a formação da Geografia e da Geopolítica desse período foi Therezinha de Castro. Essa autora escreveu, junto com Delgado de Carvalho, o livro Geografia Humana, no qual, didaticamente, tentaram estruturar um campo de análise geográfica a partir de questões ligadas desde a grupos humanos, passando por temas como a ocupação do solo pela agricultura, até a análises da indústria (CARVALHO e CASTRO, 1963). Na introdução, quando fazem uma resenha histórica da geografia, os autores frisam a relevância do pensamento geográfico de Ratzel, consubstanciando sua participação na consolidação da "Etnografia e Geografia Humana, reunindo, em suas observações e pesquisa, material considerável, que vem sendo trabalhado por seus sucessores" (idem:9). Esta passagem é interessante quando observada a presença da teoria de Ratzel nos trabalhos de Therezinha de Castro. Porém, só mais tarde, a professora passaria a realizar a aplicação do pensamento geopolítico à realidade nacional, com base, sobretudo, em Mackinder e Mahan. 
No livro Nossa América: geopolítica comparada, é possível ter clareza de seu tratamento teórico-metodológico na Geografia e na Geopolítica. A descrição é parte crucial de seu trabalho, como podemos observar no trecho:

O litoral atlântico da região guianense é baixo e pantanoso com faixas que variam dos 20 aos $80 \mathrm{Km}$ atravessadas por vários cursos d'água entre os quais se destacam o Demerara, o Berbice, o Corentine, o Copermine, o Maroni e o Mana.

(CASTRO, 1994:93)

A partir daí, sua relação com os aspectos estratégicos fica clara:

A homogeneidade estrutural do Planalto das Guianas é notória, como é também indiscutível o seu isolamento geográfico entre o Atlântico e Bacia Amazônica e do Orenoco, tal isolamento geográfico justifica em grande parte 0 esfacelamento geopolítico com a invasão estrangeira no litoral guianense. (idem:93)

Por ter formação em História, Therezinha de Castro, e aí insere-se sua particularidade, utiliza muito eventos e comparações, como a realizada entre Brasil e Estados Unidos. Na visão dela, por exemplo, enquanto nos Estados Unidos a abolição foi consequência da rivalidade econômica entre o norte e o sul; no Brasil, o problema da abolição refletir-se-ia numa luta de classes: "contra os grandes proprietários da aristocracia rural colocaram-se alguns intelectuais desprotegidos, interessados no problema" (op. Cit:253), que ela denomina como uma versão brasileira do que ocorrera nos Estados Unidos.

As descrições, os contextos históricos juntaram-se para proporcionar sempre um olhar sobre as estratégias americanas na América Latina, assim como para voltar-se à descrição dos conflitos, ora remetendo-se ao Canal do Panamá, ora à Cuba ou a qualquer outro espaço do nosso continente. Ficava clara, portanto, uma menção militarista e preocupada com as relações diplomáticas que se estabeleciam por força das estratégias de tal ou qual país. A autora também resgata o conceito de Heartland de Mackinder para fazer 
alusão à Rússia: "embora não tivesse a Rússia todo o Heartland sob seu domínio em face da exclusão da Alemanha Ocidental, o Kremlim controlava boa parte da 'Ilha Mundial'” (op. Cit.:359). É notável que suas proposições em relação aos conflitos analisados foram as de aproximar Estados Unidos e Brasil:

os Estados Unidos devem tomar consciência de que ante o enfraquecimento de suas alianças tanto Leste-Oeste quanto Norte-Sul, ocupam, no âmbito das Relações Internacionais, um posicionamento geoestratégico debilitado. E, diante da problemática mundial, o Brasil deve ser atraído como um país amigo e bem orientado para uma aliança que o coloque como peça importante numa região de contenção do Atlântico, ante uma área conflitual caribenha, com presença de Cuba e uma zona vulnerável que envolve as vias marítimas da costa da África Ocidental ate o Índico.

(op. Cit::358)

Indiferente ao posicionamento político de Therezinha de Castro, o que deve ficar claro é sua filiação a um pensamento geopolítico fortemente calcado na estratégia territorial do Brasil e na consolidação de sua posição internacional. Mesmo esse livro tendo sido escrito posteriormente ao desenvolvimento das obras de Golbery do Couto e Silva, nossa opção por citá-lo antes foi diretamente ligada à ênfase que pretendemos dar a esse homem que, não só desenvolveu inúmeros trabalhos escritos quanto ao pensamento geopolítico nacional, como também participou ativamente da construção da política nacional, no período militar.

Golbery do Couto e Silva teve toda a sua formação ligada ao exército. Iniciando sua carreira em 1927, o general passou por muitos postos dentro do exército brasileiro até chegar, em 1952, ao departamento de estudos da Escola Superior de Guerra. É nesse momento que sua trajetória de escritor e pensador da estratégia nacional se acelera substancialmente, com a publicação de diversos textos, livros e confecção de discursos utilizados por autoridades 
brasileiras $^{41}$. Seus escritos, sempre trazendo referências clássicas ligadas ao poder e à questão estratégica nacional, foram adotados por partidários do regime militar e severamente criticados por acadêmicos de diversas áreas, mas, sobretudo, da Geografia e das Ciências Sociais. Este fato é facilmente explicável: sua posição era, declaradamente, contra a democracia e contra o federalismo brasileiro, ou seja, fortemente baseada na unidade-nacional como elemento estruturador da nação e da segurança nacional (MIYAMOTO, 1981). Nas palavras de Golbery: "Maximizar o poder nacional, em face das exigências impostas pelo fantasma da guerra que já nos persegue - eis um dever a que se não podem esquivar, de forma alguma, as nações, atentas ao futuro que de todas se avizinha a passos tão adiantados" (COUTO e SILVA, 2003:10).

O poder absoluto nas mãos da nação e um contínuo questionamento sobre a paz no mundo são exatamente os pontos de partida para a defesa, por parte de Golbery, de um ideário antidemocrata e centralizador. No que diz respeito à paz, Couto e Silva (idem:18-19) questiona a democracia com base na visão de que a criação de um sistema internacional, baseado na luta das nações 'democráticas' contra o socialismo, não se efetivava do ponto de vista prático, já que não havia segurança em meio ao conflito que se travava à época. Portanto, só a segurança nacional seria capaz de ultrapassar as adversidades e colocar o país em uma posição mais favorável.

Em relação ao questionamento à democracia, Golbery usa o termo 'liberalismo fisiocrático fracassado', querendo expressar que o liberalismo gerava uma tensa relação entre os interesses individuais calcados no mercado e a geração de uma política verdadeiramente voltada à nação. Também dava indícios de que a democracia inglesa e americana eram fortemente baseadas

\footnotetext{
${ }^{41}$ Elio Gaspari foi o responsável por fazer a apresentação de uma coletânea de textos de Golbery do Couto Silva, lançada em 2003, com o título de Geopolítica e Poder. Na breve análise que Gaspari faz sobre o autor, há um relato sobre a atuação do general em discursos e manifestos públicos nas décadas de 1950 e 1960. Relembra-nos Gaspari sua participação como redator de alguns documentos históricos: do Memorial dos Coronéis, em 1954, fato que gerou, inclusive, a renúncia do então Ministro do Trabalho, João Goulart; do discurso proferido pelo general Canrobert Pereira da Costa, ocasião em que há uma rixa entre militar e Vargas; e do Manifesto à Nação, divulgado pelos militares em 1961 contra a entrega do poder ao então vice-presidente, João Goulart.
} 
na segurança nacional e, portanto, discutíveis ${ }^{42}$. Assim, só o Estado seria o elemento capaz de dar ao cidadão aquilo de que ele, realmente, necessitava. Estado, este, assentado nos interesses nacionais, já que representava a segunda família do cidadão e, claramente, aquele em que o cidadão poderia confiar.

A base teórica para a defesa do autoritarismo, Couto e Silva (op. Cit.:4) retira de Hobbes. "Ora, Hobbes pode bem considerar-se como o patrono, reconhecido ou inconfessado, das modernas ideologias políticas que ameaçam, por todos os lados, o mundo decadente de um liberalismo impotente e exausto". Neste ponto, a democracia seria um discurso que serve de base àqueles que querem tirar proveito da situação política da nação em causa própria. A saída seria, então, o uso da força estatal sem medidas para atingir a paz, com base nos objetivos nacionais claramente delimitados. Para dar cabo de tal meta, Golbery traça, ao longo de toda sua obra, uma verdadeira engenharia da estratégia nacional, baseando-se em uma série de medidas para o funcionamento perfeito do estado.

O trecho abaixo reflete toda a temática tratada anteriormente:

Ora, devendo a estratégia coordenar as diversas estratégias particulares, certamente só poderá fazê-lo mediante conciliação entre os interesses unilaterais, e por vezes antagônicos, destas, sacrificando em partes alguns deles em benefício dos outros, sempre que daí resultem vantagens ou salvaguardas para os interesses gerais e supremos ligados à consecução ou salvaguarda dos objetivos nacionais.

(op. Cit.:96)

\footnotetext{
${ }^{42}$ Para ele também, são essas mesmas nações, em especial os EUA, que semeiam os ideais democráticos que dão fôlego às mazelas da corrupção e da demagogia. "Ante a investida multiforme e tenaz de um novo imperialismo insaciável que empunha, nas mãos hábeis, uma ideologia dissociadora, pretensamente campeão da justiça social e das verdadeiras liberdades do homem, que se mascara sob as mais justas aspirações nacionalistas e os mais nobres ideais democráticos, que faz da demagogia o seu melhor aliado e, da corrupção o cúmplice mais fiel, que solapa todas as crenças e desmoraliza todas as virtudes, que repudia a religião como ópio dos povos e propaga um fanatismo estéril, que escraviza, que envenena, que mata - damo-nos bem conta hoje das graves e múltiplas vulnerabilidades que o Brasil apresenta, e as quais urge reparar sem tardança, para que não venhamos a soçobrar neste embate gigante entre dois mundos irreconciliáveis" (COUTO e SILVA, 2003:141).
} 
A concatenação de todo esse ideário com o planejamento estratégico nacional em Golbery é observada na busca da Geopolítica como sua afirmação 'teórica', estabelecendo forte referência com os clássicos: Ratzel, Kjellén, Haushofer, Mackinder, Mahan, Spykman. Na sua concepção, a Geopolítica era a fundamentação geográfica da ação política e da proposição de diretrizes políticas feitas com base nos fatores geográficos, através dos conceitos fundamentais de espaço e posição (op. Cit.:145). Ainda, ela estaria subordinada à política, aplicando a ela os conhecimentos geográficos. Segundo Couto e Silva (op. Cit:27), seria uma arte "que se filia à política e, em particular, à estratégia ou política de segurança nacional, buscando orientá-las à luz da geografia dos espaços politicamente organizados e diferenciados pelo homem", sempre aliada ao nacionalismo "sadio que deve inspirar, motivar, permear tôda (sic) elaboração política, tôda (sic) a concepção estratégica, tôda (sic) a formulação geopolítica" (COUTO e SILVA, 1967:101).

Para suas análises, Golbery utilizava longas descrições sobre o posicionamento do Brasil e suas diferenciações internas, diferenciações, que iriam servir de base para uma geopolítica brasileira, segundo ele, fundamentada em três fases ${ }^{43}$. A partir dessas bases, que não cabe citar aqui, pela extensão, é que a noção de 'estratégico nacional' passa a ser utilizada para a proposição de seu planejamento nacional. E é exatamente aí que toda a aplicação de sua 'teoria' Geopolítica se fez valer.

Em 1959, quando Golbery escreveu seu texto Evolução do Conceito, ficou clara uma estruturação para a utilização do estado. O autor partiu da ideia de 'Objetivos Nacionais' definidos como tradução das aspirações e interesses de todo o grupo nacional, dividido em: permanentes, ou seja, aqueles que perduram, como integração nacional, autodeterminação ou soberania, bemestar e progresso; e os atuais, representados pelas limitações impostas pelas possibilidades do momento e, em particular, pelos antagonismos internos e

\footnotetext{
${ }^{43}$ A primeira seria articular a projeção continental, ligando o Nordeste e o Sul ao núcleo central do país. A segunda ligada a um avanço da onda de colonização para o Noroeste, a partir da plataforma central, integrando o Centro-Oeste ao resto do Brasil. Por fim, "inundar de civilização Hiléia amazônica, a coberto de nódulos fronteiriços, partindo de uma base avançada no Centro-Oeste, em ação coordenada com a progressão E. - O. segundo o eixo do grande rio" (COUTO e SILVA, 1967:132)
} 
externos. Esclarecidos os objetivos, seria, então, a hora de pensar na 'política nacional', ou seja,

a governação do estado com vistas à consecução e salvaguarda dos objetivos nacionais. Com isso, chegaria a definição da 'estratégia nacional', como a "orientação e direção tanto do desenvolvimento e reforço dos recursos nacionais, como sua aplicação, à fim de promover efetivamente a consecução e salvaguarda dos objetivos nacionais.

Por fim, a 'segurança nacional', como a garantia do Estado proporcionar à coletividade seus objetivos, seria a estratégia em si: "a estratégia é a política nacional de segurança" (COUTO e SILVA, 2003:189).

É indiscutível que esse conteúdo geopolítico de Golbery aplicado à realidade brasileira, com ênfase no período militar no Brasil, aliado à verbalização contra a democracia, vai servir de base para toda crítica e desalinho de um pensamento geopolítico nacional. Pensamento este, geopolítico e não de Golbery, que pode e deve ser resgatado, obviamente, em outras bases, para a formulação de fundamentos críticos de defesa de interesses nacionais, como aspectos ligados aos setores produtivos da saúde, fundamentais para população brasileira e custosos para o país, evidenciados no capítulo 4.

Ainda antes de entrar em outros caminhos, muito mais acertados, que a Geopolítica brasileira desbravou após Golbery, cabe uma breve menção ao general Meira Mattos, um dos últimos grandes notórios geopolíticos da escola militar brasileira. Mattos (1979:xiv) inicia seu livro deixando clara a influência que Mario Travassos teve em sua trajetória, sobretudo quando este analisou questões relativas aos antagonismos geográficos, às políticas de comunicações e à instabilidade territorial. No que tange aos clássicos, seu posicionamento não é diferente do de seus antecessores, ou seja, Ratzel, Kjellén, Mackinder, entre outros, sempre com ênfase no papel da Geografia no desenvolvimento das atividades humanas. A "terra sempre teve influência 
muito grande no destino do homem, assim como o país no dos povos e, juridicamente falando, o território no destino dos Estados" (idem:7). A partir dessa base, Meira Mattos passa a descrever as influências das formas e do posicionamento dos estados na política dos países, conceituando, por exemplo, que uma 'forma fragmentada' é desvantajosa para o exercício de soberania de um país, como no caso da Prússia antes da unificação da Alemanha ${ }^{44}$. Para esse autor, com o conhecimento dessas influências, caberia ao estadista verificar criteriosamente quais as mais decisivas para o efeito político desejado, deixando clara toda a aplicabilidade de sua teoria.

Quando pensa o Brasil, Meira Mattos não foge a essa regra. Sempre baseado em estratégias territoriais de desenvolvimento da nação, Mattos (idem:69) ressalta a importância da combinação de influências marítimas e continentais do Brasil para o seu 'destino geopolítico' como verdadeira fonte de benefícios e instrumentos de poder ${ }^{45}$. São os 'estímulos' marítimos e continentais que serviram de base para o autor propor três 'áreas geoestratégias' brasileiras: o Atlântico Sul, a Bacia do Prata e a Amazônia. Esta última, inclusive, foi estudada em seu livro Uma Geopolítica PanAmazônia, em que Mattos (1980), após uma descrição dos processos históricos de desenvolvimento dessa região, propõe uma 'projeção geopolítica amazônica' fortemente baseada na questão de seus próprios limites, com

\footnotetext{
${ }^{44}$ Meira Mattos (1979:17) pontua: "além do núcleo central em torno de Brandemburgo, havia ilhas prussianas esparsas pela Renânia e no Hanôver, os chamados exclaves".

${ }^{45}$ Nesta passagem, Meira Mattos explicita uma forma de determinismo, afirmando que a ciência e a tecnologia podem até servir de instrumento para diminuir a dependência do Estado em relação à sua Geografia, mas melhor ainda é quando o Estado é capaz de aplicar "a moderna tecnologia a favor de suas potencialidades geográficas". Mas é importante frisar que Mattos não compartilhava daquele clássico determinismo climático. Mattos (1984:11) escreve que "Há pouca observação científica, que se conheça, sobre as condições climáticas de trabalho favoráveis ao habitante dos trópicos. Sabe-se que ate os dias atuais ele não foi capaz de criar um centro portador de cultura superior de padrões tecnológicos industriais". Contudo, o autor, mais à frente, vai repudiar este propósito afirmando: "Não há porque aceitar esta condenação por motivo de nascimento. Outros cientistas, talvez melhor informados face à modernização dos métodos e processos à disposição do homem para superar os óbices oferecidos pela natureza, defendem teorias diferentes que não valorizam de forma tão incisiva, às vezes até determinista, a importância do meio físico favorável. Entre antropólogos, etnólogos e historiadores modernos a tendência é repelir esse determinismo geográfico" (idem:15).
} 
'áreas fronteiriças de irradiação' e 'faixas ou centros formadores de fronteiras' servindo de base para seu desenvolvimento econômico ${ }^{46}$.

Por fim, é necessário enfatizar o esforço que Meira Mattos faz para pensar o Brasil como uma 'potencia mundial', sobressaindo-se à noção de 'potência continental' proposta por Mario Travassos. Entre seus argumentos, podemos destacar que "nenhuma nação do mundo, neste século, deu 'o seu salto' em período menor de 25 a 30 anos" (MATTOS 1979:103). A 'viabilidade' para ser potência viria de sua dimensão geográfica e população, com base em diversos estudos de especialistas internacionais, que nos colocavam como promissores junto à China, Índia, Japão, Canadá, México, Argentina, África do Sul, Austrália e à Comunidade da Europa Ocidental. Porém, Brasil e China seriam os mais aptos, já que os "fatores território, população, recursos naturais, indústria, tecnologia e ciência e coesão interna" melhor se harmonizariam e se completariam com perspectivas de futuro (idem:116).

\subsection{A Retomada da Geopolítica: a Inovação Tecnológica no Centro do Debate}

Em paralelo com essa Geopolítica militarista e fortemente voltada à aplicação na vida política do Estado, surgem as propostas de Bertha Becker para revolucionar o pensamento geopolítico brasileiro, bem como as pesquisas em Geografia no Brasil. Nascida no Rio de Janeiro, mas filha de imigrantes do leste europeu, Bertha Becker passou a ter interesse acerca dos fenômenos ligados às fronteiras e ao movimento. Em entrevista à revista Caderno de História da Ciência, a intelectual pontuou que todo o ambiente característico da década de 1930, com a criação do IBGE, as publicações de Delgado de

\footnotetext{
${ }^{46} \mathrm{O}$ autor baseia sua estratégia com referências às experiências geopolíticas do passado e na Geo-História. "A tese de que a Geopolítica deve apoiar-se na Geo-História encontra impressionante suporte quando olhamos o mapa em que o historiador português Jaime Cortesão fixa os centros formadores das fronteiras sul-americanas. Aí viemos encontrar, com surpresa nossa, as mesmas três áreas interiores de intercâmbio fronteiriço que selecionamos antes de ter nos deparado com o referido mapa histórico" (MATTOS, 1980:170). Essas três frentes históricas seriam: a das vertentes andinas, a do Planalto Central e a do litoral atlântico.
} 
Carvalho, o fortalecimento do Estado nacional, a defesa das fronteiras e a própria necessidade de conhecimento do território, levou-a à Geografia. Logo após estar formada, passou a lecionar como auxiliar de ensino do professor Hilgard Sternberg, na Universidade Federal do Rio de Janeiro, quando recebeu um convite para substituir, no Instituto Rio Branco, um professor falecido. Esse foi o momento em que a Geografia e, em especial, a Geopolítica brasileira deram uma verdadeira guinada. Deparada com um programa disciplinar geográfico clássico, pautado na distribuição das plantations, dos sistemas asiáticos, Bertha Becker colocou-se em uma encruzilhada: como fazer um ensino verdadeiramente útil à diplomacia brasileira. Foi então que, ao estudar Mackinder e outros clássicos, chegou à conclusão de que o caminho seria a Geopolítica. Sua trajetória, a partir desse ponto, volta-se cada vez às reflexões geopolíticas, tendo publicado textos fundamentais à compreensão da Geografia brasileira.

Em um primeiro momento de sua carreira intelectual, Bertha Becker chegou a negar a abordagem da Geografia Política, por ser, "extremamente fraca nas suas bases conceituais e teóricas" (BECKER, 1974:5). No estudo em questão, Becker preferiu utilizar, com ressalvas, a teoria do desenvolvimento polarizado de Friedmann para realizar uma análise acerca da realidade amazônica, na estrutura espacial do Brasil. A preocupação central da autora, naquele momento, advinha do fato de que a região em questão ainda não havia conseguido suplantar seu 'isolamento físico e mental' do restante do país, podendo ser chamada de 'periferia não integrada' dentro do espaço nacional (idem:7-9). Apesar da negação da Geografia Política, verifica-se nesse texto que Bertha Becker já possuía um pensamento claramente geopolítico: "a integração nacional é vista como capaz de promover o equilíbrio geopolítico interno", assim como as "implicações geopolíticas de ordem externa não são menos importantes" (op. Cit::11).

A questão da estratégia, com conteúdo geopolítico, é esclarecida em algumas passagens. Em um primeiro momento, a autora afirma ser a região amazônica um lugar estratégico, pois seria capaz de atrair "inovações e efeitos difusores de desenvolvimento, tal como capital, tecnologia e população - tanto 
de centros nacionais como mundiais (...)" (op. Cit.:12). Depois, para propor o desenvolvimento regional, Becker (op. Cit.:30) enumera quatro funções: a demanda de recursos; a implantação de transportes e comunicações; a diversificação de sua estrutura econômica e a capacidade de ganhar ou reter poder de decisão. Ou seja, para os dois casos o pensamento geopolítico é claro, já que parte de uma concepção espacial para pensar o desenvolvimento.

O desenvolvimento regional e a geopolítica sempre caminharam juntos nas reflexões de Betha Becker. O exemplo anterior é apenas um entre os vários que nos permitiriam verificar esse ponto. Becker e Egler (2003[1992]:123-131) realizaram um esforço para compreender a 'modernização conservadora' do período militar com base no projeto geopolítico da época, segundo eles 'doutrina explicita' de estratégia e prática do Estado, que visava a implantação da fronteira científico-tecnológica no 'core' área do país, a integração do território, incorporando a Amazônia e a projeção no espaço internacional. Posteriormente, os autores fazem uma alusão às potenciais saídas da crise que o Brasil vivenciava na época, fundamentadas no território, já que a "leitura do território permite desvendar os interesses em jogo no processo de reestruturação da economia e da sociedade" (idem:216), sendo a Amazônia considerada uma 'incógnita' dada a mobilização internacional contra o desmatamento e seu potencial, desconhecido, no que tange à ciência e à tecnologia (op. Cit::251). É interessante notar que mesmo os autores não tendo feito uma proposição geopolítica, esta foi a base para as reflexões do desenvolvimento regional, o que reforça a busca por parte de Bertha Becker de uma aproximação da questão regional e da geopolítica.

Agora, essa aproximação fica ainda mais evidente no seu livro Amazônia. Geopolítica na virada do III milênio. Becker (2004:20-21) inicia sua reflexão a partir de três componentes principais relacionados à Amazônia: a sua dinâmica regional, na década de 1990, constituída por políticas pregressas, atuais e processos espontâneos dos grupos sociais; a retomada do planejamento pela União, verificada no Programa Brasil em Ação (1996) e no Avança Brasil (2000-2003); as transformações globais resultantes das novas tecnologias de produção e gestão e das redes de informação e circulação. A mais interessante, 
no que tange a nossas análises, está relacionada ao último componente. Becker (idem) afirma que há um "novo significado da geopolítica, que não mais atua na conquista de territórios, mas sim na apropriação da decisão sobre seu uso". Neste sentido, autora vai pontuar os conflitos de uso do território amazônico, bem como a 'fronteira do capital natural' e a 'fronteira dos recursos $^{, 47}$, para depois propor um novo planejamento regional que esteja fortemente vinculado a um projeto nacional e ao resgate do papel do Estado. $E$ aqui toda a acepção geopolítica de Becker fica clara ${ }^{48}$.

Se for verdade que sua contribuição para pensar a Geopolítica e a região de maneira conjunta é inegável, suas proposições teóricas sobre Geopolítica e Geografia Política são ainda mais. Dois artigos publicados pela Revista Brasileira de Geografia ${ }^{49}$ podem ser considerados clássicos, exatamente por abordar a revisão dessas teorias. Porém, trataremos especificamente deles ao final deste capítulo, já que baseiam nossa proposta de que a inovação é, cada vez mais, elemento central da Geopolítica mundial.

Ainda no que tange o pensamento geopolítico, alguns autores precisam ser referenciados no que concerne ao desenvolvimento de propostas voltadas ao desenvolvimento da Geopolítica e da Geografia Política.

Lia Osório Machado vem, desde a década de 1980, estabelecendo reflexões de cunho geopolítico. A contribuição de Machado (1993) que estabelece uma clara relação entre Geopolítica e inovação, será retomada mais adiante. Neste ponto cabe ressaltar que seus trabalhos têm caminhado em direção a análises das fronteiras amazônicas e, em grande parte, à geopolítica ligada ao tráfico de drogas no Brasil. Primeiro, devemos ressaltar

\footnotetext{
${ }^{47} \mathrm{O}$ conflito ao qual a autora faz menção se refere, entre outras, às potencialidades amazônicas, oriundas da floresta - como a natureza servindo à biotecnologia, valorizadas "como capital de realização atual ou futura e como fonte de poder para a ciência contemporânea" (idem:35). Que, nesse caso, soma-se à falta de regulamentação jurídica por parte dos territórios que têm essas potencialidades, assim como à falta de uma regulamentação internacional adequada ao uso desses recursos naturais. Este fato é claramente verificável nas discussões sobre a apropriação de moléculas oriundas da Amazônia, por parte de grandes corporações transnacionais, sem pagamento de nenhum tipo de benefício para os países que detêm o recurso do qual é extraído o principio ativo.

${ }^{48} \mathrm{Em}$ relação às discussões propositivas sobre Geopolítica e planejamento na Amazônia ver Becker $(2004 ; 2005)$.

${ }^{49}$ Ver Becker (1988; 1991).
} 
que Machado (2007:24) delineia toda a importância geoestratégica da região amazônica, afinal,

A extensão territorial da região se traduz em imenso "estoque" de terras, de água e de outras riquezas naturais para investidores nacionais e estrangeiros; os serviços ambientais que a cobertura vegetal porventura presta ao clima do planeta a situam no centro dos debates sobre se é ou não patrimônio nacional ou da humanidade; a dificuldade em dar voz a vários grupos sociais (indígenas, ONGs, grandes empresários, semterra etc.) e, ao mesmo tempo, em fazer valer a idéia clássica e histórica de defesa do território e da soberania estatal num espaço de redes de vários tipos e procedências.

Nesse estudo, a autora aponta os efeitos políticos e econômicos do que denominou Macropolítica ${ }^{50}$ ligada à questão das drogas. Recebem destaque as políticas que Machado (op. Cit:24) denominou de "linearmente de cima para baixo pelos governos centrais e as atuações efetivas dos diversos agentes no terreno". Esta é uma clara alusão ao papel dos EUA na região com a forte pressão em países como o Peru e a Colômbia, os principais produtores mundiais de cocaína. Em sua visão, as iniciativas de planejamento dos Estados nacionais deveriam seguir uma abordagem através de um controle distribuído capaz de identificar interações entre os diferentes agentes, mas sem ingerência externa exacerbada. Essas observações destacam a relevância do pensamento geopolítico na concepção de Lia Osório Machado.

Wanderlei Messias da Costa, por sua vez, iniciou seus esforços na compressão clássica da Geopolítica e da Geografia Política, no início da década de 1990, com um estudo que, além da revisão dos clássicos, propunha pelo menos três aspectos fundamentais da Geografia Política contemporânea:

\footnotetext{
${ }^{50}$ Esse termo faz referência ao contexto institucional e legal criado no Brasil, sobretudo a partir da década de 1990, como, por exemplo a criação da Secretaria Nacional Antidrogas (Senad, 1998), e de um Conselho Nacional Antidrogas (Conad), ambos subordinados ao Gabinete de Segurança Institucional, diretamente vinculado à Presidência; e as medidas para controlar a lavagem de dinheiro, com a Lei 9.613/1998, que ficou conhecida como "lei da lavagem", que a tornou crime federal (a mesma lei criou o Coaf) (idem:12 e 18). Claro que essas duas medidas são apenas dois exemplos que a autora cita; afinal, sua análise perpassa até o ano de publicação do texto.
} 
o significado atual do Estado moderno; problemáticas ligadas às fronteiras; e o debate acerca das nações e dos nacionalismos (COSTA, 2010[1992]).

Costa (1999), mais tarde, passa a concentrar esforços em análises sobre a integração sul-americana. A "estabilidade geopolítica (na acepção ratzeliana), observada hoje na redução, a níveis praticamente residuais, dos contenciosos fronteiriços ou de qualquer outra natureza" (idem:26) incitava a necessidade de novas análises do processo de integração. Essa perspectiva leva Costa (2009) a realizar uma reflexão geopolítica sobre a região.

Para esse autor, devemos levar em conta três dimensões da geopolítica na atual ordem mundial: a primeira, relativa à sofisticação do sistema político em escala mundial, organizado e operado em um contexto de aceleração dado pela globalização; a segunda, seria dada pela tendência de integração de macro-regiões de escala sub-continental; e, por fim, a presença de duas centenas de estados nacionais definidos territorialmente por fronteiras e regiões internas, que ainda detêm papéis relevantes (idem:2). Essas dimensões seriam fundamentais para pensar, não a América Latina, que, segundo o autor, seria uma 'entidade abstrata', e sim, a América do Sul como região geopolítica, "uma entidade política transnacional dotada de unidade mínima e arcabouço institucional baseados em princípios e macro-objetivos comuns nas relações internacionais" (op. Cit.:3). Aí entramos na base de suas atuais reflexões sobre a Geografia Política e a Geopolítica que seriam voltadas à contribuição da Geografia, com ênfase dada às contribuições da Geografia Política e da Geopolítica aos estudos das Relações Internacionais (COSTA, 2008).

Outra contribuição extremamente relevante ao pensamento da Geografia Política e da Geopolítica foi realizada por Castro (2005). Segundo a autora, os fenômenos aparentemente contraditórios, do final do século $X X$, colocam a política em lugar de destaque na agenda da Geografia.

Fenômenos como a globalização e a revalorização do local, o enfraquecimento do Estado-nação e o ressurgimento dos 
nacionalismos, o aumento da circulação internacional de mercadorias e de mão-de-obra e o maior controle das fronteiras, o esmaecimento das regiões e o renascimento dos regionalismos, a expansão da democracia e a intensificação da pobreza, o fortalecimento dos movimentos sociais e dos direitos da cidadania e a ampliação da exclusão são significativos da importância da geografia política, da pertinência de alguns de seus temas tradicionais e das respostas da disciplina às novas questões impostas pelos contextos da atualidade.

(idem:16)

Uma Geografia Política contemporânea, na concepção da autora, deveria ser pensada com base no espaço político qualificado a partir de dois pontos de partida: as escalas territoriais dos fenômenos políticos e a identificação do campo da disciplina (op. Cit.:80). Dentre suas reflexões, destacam-se as relativas ao federalismo brasileiro e uma análise da representação política e da geografia eleitoral. A distribuição do poder pode, portanto, ser vista como uma das principais preocupações da autora, assim como "a superação dos limites estatistas da geografia política clássica e o aprisionamento da política à economia da geografia crítica" (op. Cit.:279). Assim, uma agenda para Geografia Política brasileira deve considerar investigações sobre as dimensões espaciais da política, as condições da democracia, sobre as quais a autora reflete profundamente, inclusive analisando as diferenças, nesse aspecto, entre os países, os regionalismos, a própria geografia eleitoral, a estrutura federativa, o impacto das políticas públicas nos espaços urbanos e a reprodução das desigualdades sociais e territoriais (op. Cit.:282).

Marcio Cataia é outro geógrafo que vem contribuindo com novas abordagens da Geografia Política e da Geopolítica. Sua linha de pesquisa tem como base seu trabalho sobre a exacerbação das fronteiras internas como expressão da fragmentação do território a partir de usos corporativos no Brasil, no período imediatamente posterior à redemocratização (CATAIA:2001). Naquele momento, Cataia (idem:27-45) buscou resgatar, nas teorias da Geografia Política e da Geopolítica, os clássicos textos que abordaram o funcionamento das fronteiras, a exemplo de Ratzel, Camille Vallaux, Jaques 
Ancel, Everardo Backheuser, Claude Raffestin. Porém, o autor estava preocupado com uma abordagem que ultrapassasse o conceito de fronteira como um caráter apenas horizontal, ou seja, dar-se-ia relevância à dimensão vertical das fronteiras ${ }^{51}$.

Demandas externas aos lugares seriam responsáveis pela criação de municípios, com forte alusão à competitividade territorial que se impunha no Brasil, na década de 1990, evidenciada pela proliferação do fenômeno que ficou conhecido como guerra fiscal. Mais tarde, Cataia (2006) realizou um esforço reflexivo sobre a concepção geopolítica que pautou a criação e extinção de municípios no Brasil, em dois períodos: a descentralização, de 1946 a 1964; a centralização, de 1964 a 1985. Porém, a questão da Geografia Política na fragmentação dos municípios se configura, sem dúvidas, como sua principal contribuição.

Andre Martin (2007), por sua vez, posiciona sua reflexão no cerne do poder mundial e na possibilidade de desenvolvimento de novas potências. O autor parte do seguinte questionamento: frente à crescente interdependência econômica experimentada nas últimas décadas, faria ainda sentido insistirmos na ideia de que só as grandes soberanias territoriais poderiam aspirar à condição de potências mundiais? Martin (idem:10) rechaça a noção não cientifica da Geopolítica ${ }^{52}$, com base no argumento de que, independente de ser considerada ciência ou não, ela foi responsável pela elaboração de teorias sobre o poder do espaço e no espaço. Sua proposta é de uma visão Geopolítica 'meridionalista', ou seja, baseada na importância econômica e ecológica do Sul, já que nessa região do planeta habita metade da humanidade e se localiza $80 \%$ da biodiversidade do planeta. O fortalecimento "do Sul beneficiaria o conjunto da humanidade, ao responder com uma manobra dissuasiva, e não confrontativa, o projeto hegemonista" (idem:113). Sua

\footnotetext{
${ }^{51}$ Cataia (idem:15) parte do argumento de que pensar as fronteiras, tradicionalmente, era pensá-las como resultado das implicações e informações dadas pelos lugares, pelas relações horizontais. Com o advento do desenvolvimento das tecnologias da informação e da comunicação, informações estranhas aos lugares também passaram a fazer parte da constituição de novas fronteiras, quanto mais analisadas as competições entre entes de uma dada federação.

${ }^{52} \mathrm{O}$ autor reforça o cuidado com a desqualificação da Geopolítica, já que esse termo continua sendo muito utilizado em casos como o da invasão americana no Iraque, em 2003, com clara alusão a imposições militaristas das grandes potências (idem:10).
} 
proposta seria uma visão anti-Golbery, procurando, portanto, vincular o pensamento geopolítico às relações Sul-Sul, diferente da vertente de Golbery, que valorizava as relações com grandes potências ocidentais.

No plano internacional, diversas têm sido as formas de tratar o tema da Geografia Política e da Geopolítica. Estudos sobre as escalas de poder (Cox, 2005[1998]; Mann 2005[1984]; Duncan, Goodiwin, Halford 2005[1988]), o papel dos Estados na globalização (Mann, 2005[1997]; Glassman, 2005[1999]; Walby 2005[2000]; Shaw, 2005[1997]; Slater, 2005[1993]), a problemática das fronteiras (Hyndman, 1997); desdobramentos internacionais da questão ambiental (Basset, 2005[1988]; Shiva, 1998[1993]; Finger, 1998[1996]; Robbins, 2005[1998]), a chamada 'geopolítica crítica' ou 'antigeopolítica'53 (Ó Tuathail, 1998), abordagens a partir da geografia econômica (Taylor 2005[1981]; Harvey, 2005), entre outras. Como, do ponto de vista teórico-metodológico, nos parece mais aprazível o uso das discussões propostas no Brasil nas últimas décadas, já que enfatizam o papel estratégico do desenvolvimento tecnológico no cenário geopolítico nacional e internacional, faremos apenas uma sintética observação das análises da Geografia Econômica acerca da Geopolítica, procurando justificar nossa aproximação de um pensamento geopolítico brasileiro com ênfase na inovação tecnológica.

Os dois autores que discutiram a Economia e a Geopolítica retratados aqui são: Peter Taylor e David Harvey. É fundamental reafirmar que não se trata de uma análise da contribuição marxista em relação à inovação

\footnotetext{
${ }^{53}$ A aproximação da Geopolítica aos aspectos estratégicos ligados à defesa também passou a ser fortemente criticada por um grupo de pensadores ligados a movimentos intelectuais, termo utilizado pelos próprios autores, da escola denominada Critical Geopolitics. Pelo fato de haver uma certa aproximação, sobretudo depois dos anos 1970, com os discursos de Kissinger, entre a Geopolítica e o realismo, a Critical Geopolitics parece ser a frente de estudos mais aberta a um diálogo geopolítico mais amplo e capaz de abarcar aspectos intrínsecos às realidades dos países, assim como uma visão do poder não apenas baseado no Estado (anti-geopolítica). Ó Tuathail escreveu em 1996 um livro intitulado Critical Geopolitics. A ideia central era, de alguma forma, negar uma Geopolítica fortemente centrada nas estratégias e revelar a política oculta do conhecimento geopolítico. "Since geopolitics has for so long been a militaristic practice monopolized by statist elites, conservative politicians and geopolitical "experts," it is important that we broaden the debate and consider the many different voices-minority civil rights, post-colonial, indigenous, feminist, trade unionist, etc. - opposing the dominant understanding and practice of geopolitics by foreign policy "statesmen" and so-called "wise men" (Ó TUATHAIL, 1998:3).
} 
tecnológica e ao espaço e sim de autores que refletiram a Economia e a Geografia Política ou Geopolítica.

Taylor (2005[1981]:154) inicia seu texto fazendo menção ao fato dos clássicos da Geografia Política ainda carecerem de fundamentos claros para os ensinamentos e pesquisas em Geografia. Como as instituições políticas e as próprias ideias têm bases sólidas nas necessidades materiais da sociedade, uma aproximação com a Geografia Econômica seria complementar e necessária. Afinal, julgar que a Geografia Política se restrinja às reflexões sobre conflitos e sobre o funcionamento do estado seria uma incorreção. Assim, o quadro para se pensar a Geografia Política deveria partir de três debates.

Primeiro, a Geografia Política não deve permanecer independente mas buscar no holismo próprio da Economia Política uma nova abordagem. Segundo, a autonomia dos Estados deriva da inerente desunião da classe capitalista e, portanto, as responsabilidades do Estado advêm das demandas do próprio capitalismo, ou seja, novamente parte para uma argumentação a favor dessa proximidade entre geografia econômica e política. Por fim, reforça que o Estado é o ponto de partida fundamental da dinâmica de acumulação capitalista (idem:160). A partir dessas preocupações, Taylor propõe uma série de análises das escalas (da economia, da realidade, da ideologia) para reforçar seu argumento de que a Geografia Política deve ser pensada no quadro da economia política, mais precisamente, baseada na economia-mundo capitalista.

Harvey (2005), por sua vez, demonstra uma preocupação mais voltada à Geopolítica do capitalismo, também com forte base marxista. Inclusive, até chegar à sua proposição, o autor faz questão de centrar a discussão nas bases do desenvolvimento capitalista, bem como nas características desse modo de produção, assentadas na dinâmica tecnológica; nas relações de classes; na produção, que tem na origem do lucro a exploração do trabalho; entre outros argumentos com acepção marxista. Contudo, sua proposição central em relação à Geopolítica está pautada nas transformações econômicas, como o endividamento dos países periféricos e o domínio estadunidense sobre os organismos internacionais - com maior ênfase durante a Guerra Fria -, os 
quais, por sua vez, delinearam uma Geopolítica de manutenção e expansão dos parâmetros capitalistas de produção.

Tudo se arranjou para impedir a emergência de blocos de poder rivais dentro do mundo capitalista, e para facilitar a internacionalização do capital (principalmente nos Estados Unidos), sob condições de mobilidade geográfica razoavelmente limitada da força de trabalho. A cooptação e a repressão, no país natal e no exterior, para manter o mundo liberado para a circulação do capital, tornaram-se o tema político dominante. Para esse fim, forjaram-se novas alianças geopolíticas, e estabeleceram-se novas fundações para a coesão de alianças regionais de classes dentro de uma estrutura internacionalista.

(idem:161)

Essa base geopolítica permitida pelo capital, como bem nos esclarece Harvey, é de suma importância para entender sua mundialização e a consolidação de um sistema capitalista, que, por sua vez, tem no desenvolvimento tecnológico uma capacidade de exercer domínio em diversas áreas produtivas, incluindo aquelas com apelo nas políticas sociais, como é o caso da saúde (ver capítulo 1).

Pelo fato do objetivo central da tese ser explicitamente uma política de incentivo à inovação como elemento estratégico do estado brasileiro, essas duas abordagens, ainda que de suma relevância, nos encaminhariam para uma preocupação mais voltada ao desenvolvimento do sistema capitalista, sua desigual distribuição pelos países, a divisão internacional do trabalho e a própria mobilidade da força de trabalho. Fato que ampliaria em demasia o escopo teórico aqui estruturado. É nesse sentido que voltamos a salientar que, no atual estágio de dependência tecnológica brasileira, verificada pela sua balança comercial (ver capítulo 4), pensar a inovação como estratégia nacional, como elemento urgente da Geopolítica, é nos preocuparmos com um projeto nacional mais profícuo. 
Bertha Becker, no final da década de 1980, já anunciava sua preocupação com uma releitura da Geopolítica. "A geopolítica não está dada ela é construída hoje, no atual período histórico, pelo trabalho humano tanto material quanto intelectual e, assim produzida tem movimento e abertura para o indeterminado, que é essencialmente político" (BECKER, 1988:101). É assim que podemos esclarecer a importância de um dos textos mais clássicos da Geopolítica nacional. Uma clara alusão não só à relevância dessa corrente, como também, à sua atualidade, ou seja, o movimento que materializa no espaço diferentes capacidades de poder. E a inovação tecnológica nada mais evidencia senão a potencialidade de um uso do território mais próximo às verdadeiras necessidades de um país, assim como fortalecer suas bases de poder.

Nesse sentido se encontra a particularidade de pensar a Geopolítica para além das formas militaristas e realistas ultrapassando seus discursos tradicionais. Ó Tuathail (2000:176) adverte para a necessidade de uma nova Geopolítica, sobretudo pelo fato dessa teoria ter ficado muito centrada nas questões derivadas da Guerra Fria. Para esse autor, as novas análises deveriam estar ligadas às problemáticas relacionadas à globalização, à informacionalização e à proliferação de riscos fora das fronteiras.

Já para Machado (1993), essas análises deveriam levar em conta a inovação tecnológica. Com a velocidade das transformações técnicoeconômicas, a introdução de novas tecnologias e sua capacidade de criação de novas estruturas de relação espaço-tempo, assim como a informatização de todos os setores de atividades produtivas, a inovação revoluciona a vida social e produtiva, tendo consequências sociais e políticas (idem: 9). Do ponto de vista do território nacional, as prerrogativas das inovações se colocam como fundamento jurídico do estado e, portanto, fundamentais para sua compreensão, tendo em vista que o desenvolvimento tecnológico não homogeneíza espaços, mas sim aprofunda suas desigualdades. Assim, Machado (op. Cit.:11) ressalta três elementos que seriam relevantes para a análise geopolítica da inovação: a garantia jurídica oriunda do estado, evidenciada pelo direito de propriedade, ao capital, às patentes ou 
informações; a distinção entre estados produtores e consumidorescompradores de tecnologia; o fato das inovações incidirem diretamente sobre o mercado de trabalho, evidenciando a necessidade do 'governo do território'.

O segundo elemento nos parece fundamental para a abordagem proposta nesta tese. Como veremos no capítulo 4, nos últimos anos, o Brasil, que mantém sua balança comercial positiva, tem sua base produtiva exportadora fortemente ligada a produtos primários. Ainda que os resultados continuem positivos na balança, o crescimento econômico leva à importação de novas tecnologias, majoritariamente produzidas por países centrais. Os produtos relacionados à saúde revelam um aspecto fundamental da dependência, afinal, são tecnologias para a manutenção da vida da população brasileira e, por isso mesmo, estratégicas na constituição da defesa dos interesses nacionais.

Se pensar a Geopolítica é pensar a atuação estratégica do Estado, a inovação tecnológica nos apresenta uma potencialidade muito relevante do ponto de vista teórico e empírico. Becker (1988), quando refletiu sobre a Geopolítica brasileira, deu forte ênfase ao papel que os geopolíticos militares tiveram na consolidação de políticas estratégicas do Estado brasileiro, sobretudo no período militar. Na ciência e tecnologia, esse período contempla "a ação direta do governo para a P\&D, em termos não só de planejamento e incentivo à empresa estatal e privada, mas de execução, esboçando-se a tendência à politica de substituição das importações de tecnologia" (idem:116). Como exemplo, a autora cita a criação da EMBRAER (1969), os Planos Nacionais de Desenvolvimento, com a instituição do Sistema Nacional de Desenvolvimento Científico e Tecnológico, em 1972, fundos especiais para pesquisa, geridos pela FINEP ${ }^{54}$, além da forte acepção militarista que articulou o desenvolvimento científico e tecnológico à produção bélica, passando o Brasil da condição de importador para a de quinto exportador do setor no final dos anos 1970.

\footnotetext{
${ }^{54}$ Uma análise mais aprofundada desse tema será desenvolvida no Capítulo 3.
} 
Motoyama (2004:323) vai mais longe ainda ao afirmar que o processo de desenvolvimento no regime militar teve suas origens na Escola Superior de Guerra e foi fundamentado na máxima de que "nenhum desenvolvimento econômico ou social de um país poderia ser feito sem que houvesse, simultaneamente, um avanço tecnológico, baseado em pesquisa científica e tecnológica realizada no próprio país". Esta prerrogativa, segundo o autor, seria parte do Programa Brasil Potência, gestado na própria Escola Superior de Guerra, baseado na Doutrina de Segurança Nacional. Golbery do Couto Silva era seu principal mentor, sendo o programa enfático sobre a "necessidade da educação e da pesquisa tecnológica como elementos imprescindíveis ao estabelecimento do poder nacional".

Obviamente não estamos aqui enaltecendo o regime militar, mas apenas pontuando essa base científica e tecnológica como central na discussão Geopolítica. Como bem observa Becker (1988:120), a Geopolítica brasileira desse período foi marcada por uma via autoritária em que tivemos o crescimento do Estado, mas não da nação, forma que incluiu da repressão à centralização da decisão e da informação, à exclusão de grande parcela da população da modernidade imposta, às formas violentas de reapropriação do espaço e que resultaram na crise do projeto e do próprio Estado. Assim, não defendemos suas bases, mas apenas enaltecemos a questão tecnológica como prioridade geopolítica desde aquele momento da história brasileira.

O legado que nos proporcionou Becker (op. Cit::121), para pensar sob esse prisma, se situa nas correspondências entre as questões gerais da Geopolítica e projeto geopolítico no Brasil. Essas correspondências seriam a expressão e o instrumento das relações de poder atuantes na produção do complexo espaço global contemporâneo, sendo seu resgate um instrumento que ampliaria a leitura e a compreensão desse mosaico. Naquele período, Becker (op. Cit::121-122) discorre sobre as novas funções do Estado na conformação de um momento de privatização das empresas brasileiras e suas conclusões apontaram para uma Geopolítica contemporânea que delineava a fragmentação do Estado e a gestão privada do espaço nacional, pela ação de 
poderosa corporação estatal e da territorialidade de grupos sociais, "faces antagônicas de um só processo".

Hoje, o tipo de resgate que Becker realizou na privatização, nos parece fundamental para compreender o desenvolvimento das políticas de inovação nas últimas décadas no Brasil. As mudanças institucionais e legais que têm sido realizadas no país apontam para uma nova realidade em relação ao desenvolvimento tecnológico e seus fundamentos discursivos e práticos são fortemente baseados na defesa dos conteúdos nacionais, nas empresas nacionais e no potencial, por exemplo, da biodiversidade brasileira. Do ponto de vista dos discursivos, que baseiam as políticas efetivas do Estado brasileiro em relação à inovação, os debates realizados ao longo das quatro Conferências Nacionais de Ciência, Tecnologia e Inovação (CNCTI) são extremamente relevantes e significativos para nossa análise, sobretudo pelo fato de boa parte dos apontamentos terem se transformado em políticas efetivas do governo. Já em relação aos fundamentos práticos, ou seja, às mudanças institucionais e legais que permitiram a concretização de políticas de financiamento à inovação no território brasileiro, esses serão devidamente abordados na segunda parte desta tese.

Como já ressaltamos, as proposições inseridas durante as CNCTI revelam um importante papel desse fórum de discussão na consolidação das políticas nacionais de inovação. A primeira conferência, ainda sem o termo inovação, em 1985, teve como principal objetivo discutir os caminhos da pesquisa científica no país em relação à democracia; afinal, apesar do crescimento científico e tecnológico vivido no período militar, a participação dos cientistas nas decisões era muito pequena.

Já na segunda CNCTI, ocorrida só em 2001, passamos a contar com a introdução da inovação como eixo fundamental. O documento de síntese deixou claro o aspecto estratégico das políticas de C,T\&I, enfatizando seu papel na construção do futuro nacional e sua adequação às mega-condições brasileiras: dimensões territoriais e populacionais, recursos naturais e biodiversidade, participação na política e na economia mundiais (SILVA e 
MELO, 2001). Entre os objetivos ${ }^{55}$, podemos destacar a modernização do aparato institucional da CT\&I como elemento que viabilizasse as políticas de incentivos (vale lembrar que a consolidação do FNDCT já estava prevista neste documento) e a visão estratégica da CT\&I no desenvolvimento nacional, fundamental para a análise geopolítica.

A terceira CNCTI aprofundou as discussões sobre CT\&I no Brasil, consolidando eixos fundamentais para o desenvolvimento tecnológico, como a inclusão social, a definição de áreas de interesse nacional ${ }^{56}$, a discussão dos marcos reguladores e a cooperação internacional (MCT/CGEE, 2006). Aspectos geopolíticos ficam cada vez mais evidentes, através desses eixos. Em relação às áreas de interesse nacional, destacam-se temas relativos tanto à Amazônia, em especial a biodiversidade com seu valor intrínseco, seus elementos positivos, suas vulnerabilidades e suas oportunidades para a região; quanto às atividades econômicas específicas, como a aeroespacial, com claras menções geopolíticas. Já no que diz respeito aos marcos reguladores, podemos citar dois pontos geopolíticos evidentes: os financiamentos à inovação, que já havia sofrido uma importante alteração com a Lei de Inovação, permitindo a subvenção econômica às empresas com projetos em áreas consideradas estratégicas para o país (ver capítulo 3); e a melhoria dos aspectos legais ligados ao poder de compra do Estado em áreas fundamentais para o desenvolvimento nacional, como é a saúde (ver capítulo 4).

A questão estratégica permanece estruturante na quarta CNCTI, realizada em 2010, porém vale ressaltar a inserção do tema do desenvolvimento sustentável na pauta principal (MCT/CGEE, 2010). Como não trataremos das questões relativas ao desenvolvimento sustentável em si, nossas análises centrarão força em outros elementos que consideramos

\footnotetext{
${ }^{55} \mathrm{O}$ primeiro seria criar um ambiente favorável à inovação que contribua para a competitividade das empresas e para o melhor aproveitamento da capacidade instalada em C\&T. O segundo estaria relacionado à ampliação da capacidade de inovação e expansão da base científica e tecnológica. $O$ terceiro estaria ligado ao aperfeiçoamento, consolidação e modernização do aparato institucional de CT\&I. O quarto enfocava a integração de todas as regiões brasileiras em tal esforço. O quinto previa a conquista de uma base ampla de apoio para esta política. E, por fim, haveria a necessidade de incorporar tal dimensão como elemento estratégico da política nacional de desenvolvimento (idem:147).

${ }^{56}$ As áreas de interesse nacional definidas foram: Amazônia, recursos naturais, aeroespacial, defesa nacional, terra, energia, mar.
} 
centrais na discussão geopolítica do tema ${ }^{57}$. Dos aspectos regulatórios, não podemos deixar de mencionar o aprofundamento do debate acerca do poder de compra do Estado, com propostas visando a flexibilização da Lei 8.666 (licitações), assim como definindo um sistema específico para as compras relativas a produtos estratégicos do Sistema Único de Saúde (SUS), questões que em muito contribuirão para a diminuição da dependência externa. No que tange às áreas estratégicas ${ }^{58}$, há uma ampliação considerável de setores a serem contemplados. Por um lado, são maiores as possibilidades de financiamento para mais áreas fundamentais relativas à tecnologia, contemplando as voltadas à inclusão social, como é o caso da agricultura familiar. Porém, a diversificação desse escopo inclui áreas já avançadas, como é o caso do agronegócio, permitindo um espraiamento dos recursos. De qualquer forma, a maior parte desses setores estratégicos tem grande relevância geopolítica.

As conferências de CT\&I corroboram com nossa proposição geopolítica da inovação, mas o cerne da discussão deve ser a atuação do Estado para a efetivação de um sistema nacional de inovação voltado às necessidades não só do desenvolvimento econômico, como social do país. Dada a baixa capacidade inovativa das empresas brasileiras, tanto o governo central quanto os governos estaduais vêm desenvolvendo políticas de inovação, cada vez mais contemplando empresas privadas nacionais e efetivando não só financiamentos, como mudanças institucionais claras para a consolidação desse processo.

\footnotetext{
57 Um parênteses torna-se necessário. O documento de recomendações enfatiza a fundamental importância dos gastos em P\&D passarem cada vez mais a ser realizados pelas empresas. Isso de maneira alguma desconfiguraria nossa perspectiva analítica, sobretudo, pelo fato de não estarmos defendendo que o Estado brasileiro seja a única fonte de financiamento à inovação no Brasil e sim que esse propicie condições favoráveis à inovação, para que num futuro sua participação como financiador seja cada vez menor e a inovação faça parte da realidade das empresas privadas no Brasil.

${ }^{58}$ As áreas tecnológicas estratégicas definidas foram: tecnologias ambientais e mitigação de mudanças climáticas; biotecnologia e uso sustentável da biodiversidade; recursos hídricos; recursos minerais; agricultura, pecuária , agropecuária e pesca; tecnologias de uso e manejo do solo; agronegócio; agricultura familiar; segurança alimentar; agropecuária; aquicultura e pesca; saúde e fármacos; espaço, defesa e segurança nacional; sistemas urbanos sustentáveis e segurança pública; fontes alternativas de energia e energias renováveis; biocombustíveis, bioenergia; combustíveis fósseis; materiais avançados; nanotecnologia; nuclear; tecnologias da informação e comunicação (TIC); microeletrônica.
} 
Um resgate da Geopolítica para pensar as políticas de inovação parece ser urgente e justificável do ponto de vista teórico e empírico, quanto mais em um contexto de hegemonia dos enfoques econômicos sobre o tema. A Geopolítica pode ser capaz de trazer à tona um debate da política nacional não apenas baseado nos premissas econômicas, mas também na política com base em um efetivo uso do território no Brasil.

$\mathrm{Na}$ segunda parte da tese, pretendemos enfatizar, a partir de elementos empíricos, a formação e o desenvolvimento de novas políticas públicas de inovação no Brasil, que sejam capazes de sustentação argumentativa à nossa proposição. A subvenção econômica, administrada pela FINEP, estabelece seis eixos estratégicos, que são, por natureza, geopolíticos. Desde o próprio fortalecimento das atividades de defesa, passando pela saúde e até mesmo a biotecnologia - exemplo de desenvolvimento no setor de abastecimento - são fundamentais para consolidação de uma estrutura produtiva e normativa nacional com vistas à diminuição da dependência externa.

A defesa dos interesses nacionais, como aeroespacial, energia e saúde, ligados ao desenvolvimento de novas tecnologias significa um posicionamento geopolítico, um reordenamento do poder dado por Estados desenvolvidos e grandes corporações multinacionais. Os elementos empíricos dados pelas atividades ligadas à saúde enfatizam que, acima de tudo, uma soma considerável de recursos é destinada à compra de elementos tecnológicos fundamentais à manutenção da vida no país e, por isso mesmo, deve ser considerado estratégico. 


\section{Parte II}

Subvenção Econômica e Políticas de

Indução a Inovação em Saúde: aspectos da Geopolítica Brasileira 


\section{CAPÍTULO 3. Fundamentos Institucionais e Legais da Geopolítica Brasileira: a FINEP e a Subvenção Econômica}

Apesar de os financiamentos públicos para inovação tecnológica nas empresas serem conhecidos e utilizados por vários países, há décadas o Brasil apresenta ainda uma história recente, porém não menos importante. As experiências de mecanismos de financiamento público para inovação no país têm crescido nos últimos anos, o que demonstra uma necessidade, cada vez mais urgente, de análises de efetividade e qualidade dos desembolsos governamentais. Devido ao grau de incerteza que o retorno financeiro para investimentos em inovações apresenta, os financiamentos para essas atividades são, em sua maioria, escassos na esfera privada, e na esfera pública, apesar do relativo consenso da necessidade de criar mais e melhores condições, foi só na segunda metade da década de 2000 que tivemos a consolidação de linhas mais sólidas, tanto de financiamentos reembolsáveis, como de não reembolsáveis. É nesse sentido que se pretende avaliar a principal linha de fomento não reembolsável do país, a Subvenção Econômica à Inovação da Financiadora de Estudos e Projetos (FINEP), em relação aos seus aspectos qualitativos e quantitativos, como subsídio à reflexão da geopolítica brasileira.

Esse modelo de financiamento teve sua primeira versão no ano $2006 \mathrm{e}$, em seguida, sofreu algumas transformações. É importante ressaltar que, quando tratamos de Subvenção Econômica, não nos referimos apenas à modalidade de financiamento direto às empresas, mas também às linhas do Programa de Apoio à Pesquisa em Empresas na modalidade subvenção a micro e pequenas empresas - (PAPPE SUBVENÇÃO), gerido pelas Fundações de Amparo à Pesquisa (FAPs) em alguns estados brasileiros. Porém, aqui nos resguardaremos unicamente à análise dos editais da Subvenção Econômica à Inovação ${ }^{59}$; até o momento, são quatro editais, com a

\footnotetext{
${ }^{59}$ Chamada Pública MCT/FINEP/SUBVENÇÃO ECONÔMICA À INOVAÇÃO - 01/2006.

Seleção Pública MCT/FINEP Subvenção Econômica à Inovação - 01/2007.

SELEÇÃO PÚBLICA MCT/FINEP/FNDCT Subvenção Econômica à Inovação - 01/2008.
} 
participação de milhares de empresas, recursos da ordem de $\mathrm{R} \$ 1.569$ milhões e 825 contratos, até o ano de 2009.

A análise dessa linha de financiamento tem um apelo territorial muito forte, afinal seus desembolsos só confirmam a grande concentração espacial de atividades ligadas a CT\&I. O Sudeste é o grande 'ganhador' dos projetos e suas empresas são as que mais se mostram aptas a conseguir o financiamento, mesmo considerando um importante detalhe: até hoje, todos os editais resguardaram $30 \%$ do total disponibilizado para as regiões Nordeste, Norte e Centro-Oeste, ou seja, as tentativas de desconcentração do desembolso não se efetivaram, o que merece atenção. Por outro lado, sua dimensão geopolítica não pode ser desprezada, sobretudo por definir áreas estratégicas que visam a diminuição da dependência na produção de certas tecnologias, como de defesa nacional, saúde e biotecnologia.

Por se tratar de uma linha completamente inédita, já que, até o final de 2004, o financiamento não reembolsável para as empresas era proibido por lei e passou a ser ferida por uma instituição, a FINEP, mais voltada ao fomento à pesquisa em ITCs e universidades públicas, pretende-se, em primeiro lugar, apontar como vêm sendo tratada a discussão teórica em relação às instituições de maneira a não confundir o tratamento das mudanças relacionadas à FINEP com nenhuma aproximação à escolas institucionais, que serão brevemente comentadas. Assim, desenvolver-se-ão as análises da trajetória legal e institucional que tornou possível esse mecanismo, assim como suas dificuldades de efetivação e seus laços com a Política Industrial Tecnológica e de Comércio Exterior (PITCE), o Plano de Ação de Ciência, Tecnologia e Inovação 2007-2011 (PACT\&I) e a Política de Desenvolvimento Produtivo (PDP).

No que se refere à questão legal, a subvenção parece estar de acordo com o que Bastos (2006:425) alertava tendo em vista as restrições do comércio internacional aos apoios diretos às atividades produtivas, afinal ações como a subvenção são praticadas em países desenvolvidos para a promoção da

SELEÇÃO PÚBLICA MCT/FINEP/FNDCT Subvenção Econômica à Inovação - 01/2009. 
competitividade, "ainda que através de ações dirigidas às pequenas e médias empresas, à redução das disparidades regionais, às adaptações decorrentes das mudanças ambientais e ao apoio à pesquisa e desenvolvimento", elementos estes presentes na subvenção praticada pelo Brasil. Já no que tange à questão legal, além dos aspectos constitutivos que deram escopo ao financiamento, abordar-se-á a necessidade de melhoria da Lei 8.666, que trata das compras públicas no Brasil. Pela subvenção ter delimitado áreas consideradas estratégicas para o desembolso, a efetividade da política teria melhores resultados se, atrelado ao financiamento, tivéssemos um poder de compra do Estado atuando para efetivar as inovações dos projetos financiados pela própria subvenção e por outras políticas governamentais.

Em um segundo momento, será realizada uma análise mais quantitativa da política, utilizando o banco de dados organizado pelo Instituto de Pesquisa Econômica Aplicada (IPEA) ${ }^{60}$. Enfocaremos uma série de análises dos números da Subvenção, sua trajetória, algumas mudanças nos editais que trouxeram consequentes alterações no padrão das empresas contratadas, assim como a relação das empresas que participaram do financiamento e a relação dessas com outros mecanismos de financiamento, tanto da FINEP quanto de outras instituições públicas, como o BNDES e o CNPq. Também será dada ênfase à análise do perfil das empresas com base em três recortes: por Unidades da Federação (UF); por porte e pela comparação entre as empresas da Relação Anual de Informações Sociais (RAIS), dos Fundos Setoriais (FS) e da própria Subvenção Econômica. Por fim, será realizada uma apreciação do trabalho de campo realizado em oito empresas, das quinze que receberam os maiores recursos da subvenção. O intuito é fazer uma análise

\footnotetext{
${ }^{60}$ Os dados compilados são oriundos: da Pesquisa Industrial Anual (PIA) e da Pesquisa Industrial sobre Inovação Tecnológica (Pintec), ambas do Instituto Brasileiro de Geografia e Estatística (IBGE); da Relação Anual de Informações Sociais (RAIS), do Ministério do Trabalho e Emprego (MTE); da Secretaria de Comércio Exterior (Secex), do Ministério de Desenvolvimento Indústria e Comércio Exterior (MDIC); do Censo do Capital Estrangeiro (CCE) e do registro de Capitais Brasileiros no Exterior (CBE), do Banco Central (Bacen); do Instituto Nacional de Propriedade Industrial (Inpi), da Base de Dados de Compras Governamentais do Ministério do Planejamento, Orçamento e Gestão (MPOG); do Programa de Capacitação de Recursos Humanos para Atividades Estratégicas (RHAE) do Conselho Nacional de Desenvolvimento Científico e Tecnológico (CNPq); e do Cadastro de Firmas Financiadas pelo Banco Nacional de Desenvolvimento Econômico e Social (BNDES). O período contemplado foi de 2006-2008 para as análises de cruzamento de dados e do trabalho de campo, enquanto a análise exclusiva da Subvenção Econômica foi ampliada para 2009.
} 
qualitativa do financiamento e ressaltar o processo de aquisição de duas empresas contempladas com contratos da subvenção e que, posteriormente, foram adquiridas por uma companhia multinacional, o que também se configura como uma questão crucial, já que a subvenção pressupõe o desenvolvimento de inovações em empresas brasileiras.

Dessa forma, pretende-se dar um panorama mais amplo do financiamento, apontando seus benefícios e gargalos, assim como os desafios para a consolidação deste tipo de financiamento à inovação tecnológica no país.

\subsection{Apontamentos sobre a economia institucional: à procura de um enfoque mais abrangente}

As contribuições da economia institucional, para a explicação dos elementos que favorecem ou entravam o desenvolvimento econômico, constituem um vasto campo de debate. Por estar muito centrada na análise econômica dos processos de desenvolvimento, escolhemos traçar um debate não sobre a eficiência das instituições na economia do país, mas sobre as transformações institucionais e legais ocorridas nas últimas décadas no Brasil e que favoreceram a consolidação de uma Geopolítica da inovação tecnológica, ainda que os resultados econômicos não tenham surtido o efeito desejado e que tenhamos críticas quanto à sua eficiência ${ }^{61}$. Ou seja, que entendemos a

\footnotetext{
${ }^{61}$ Para Cavalcante (2011:29), por exemplo, podemos tecer críticas quanto à efetivação dos mecanismos institucionais no Brasil, dadas quatro características sobre o fato do arranjo institucional que opera as políticas de inovação: não ser aderente à percepção da natureza sistêmica do processo de inovação, uma vez que foi concebido em um contexto em que prevalecia uma visão linear do processo de inovação; não criar incentivos suficientes para a alocação, pelos gestores e instituições públicas, de recursos no setor produtivo, direcionando maiores recursos a universidades e centros de pesquisa públicos do que a Empresas; incentivar a pulverização de recursos, com a consequente ausência de foco e escala que pode, em vários casos, reduzir a eficácia das políticas adotadas; e incentivar a reprodução de modelos e prioridades formatados em contextos distintos do brasileiro. Porém, convém observar que, de maneira alguma, isso diminui a importância dos esforços realizados nos últimos anos no país, que configura como o centro de nossa análise. A crítica de Cavalcante (idem:30) aponta para a necessidade de um aprofundamento ainda maior dessa discussão.
} 
importância das escolas ligadas à temática institucional, mas que não pretendemos desenvolver nossas reflexões com base na eficiência institucional. Assim, neste momento, pretendemos pontuar um breve debate sobre essa economia institucional e ressaltar nosso posicionamento em relação a essa discussão.

A economia institucional é considerada a escola que incorpora as instituições, bem como as formas de organização, as leis, as normas sociais, nas explicações econômicas, podendo ser divida em duas vertentes: a velha economia institucional, que está associada a Thorstein Veblen, Wesley Mitchell, John R. Commons e Clarence Ayres; e a nova economia institucional, que teria como principais formuladores Ronald $\mathrm{H}$. Coase, Oliver E. Williamson, Douglass C. North e Andrew Schotter (RUTHERFORD, 1994). Resumidamente, Rutherford (idem) defende que há uma falta de unidade da economia institucional, presente nas duas vertentes. Na velha economia institucional são identificados dois programas: o primeiro, de Veblen, baseado na dicotomia entre os aspectos pecuniários e industriais da economia, com ênfase nas investigações dos efeitos das novas tecnologias nos esquemas institucionais; e o segundo, de Commons, que trabalha aspectos legais, direitos de propriedade e organizações, suas evoluções e impactos no poder legal e econômico, nas transações econômicas e na distribuição de renda. Neste caso, as instituições são vistas como o resultado de processos formais ou informais de resolução de conflitos $^{62}$.

O mesmo autor identifica entre os novos institucionalistas pelo menos três programas de pesquisa. O primeiro, baseado em Demsetz, Alchina e Posner, com semelhanças ao de Commons, tem o foco nos direitos de propriedade. O segundo, partindo dos trabalhos de Oslon e Mueller, centrados

\footnotetext{
${ }^{62}$ As regras formais e informais também são trabalhadas pela nova escola. North (1997:4-5) delineia as regras formais como aquelas que incluem regras políticas (que definem as hierarquias políticas), jurídicas e econômicas (que definem o direito de propriedade), assim como os contratos (que dão provisões aos acordos de troca). Os informais, não podem ser precisamente definidos, já que estão baseados na rotina, na cultura, nas tradições e promovem mudanças desnecessárias ou impróprias, na medida em que contam com uma relativa subjetividade. Prevalecendo as regras informais, as instituições não se tornam efetivas do ponto de vista econômico. Vale ressaltar que o autor não propõe que uma sociedade deve apenas ser considerada pela via formal, e sim, que as duas formas são importantes (NORTH, 1990).
} 
essencialmente nos processos de escolha pública, incluindo os que envolvem 'rent seeking' ou coalizões para ação coletiva. Por ultimo, Coese, preocupado com as organizações, incluindo basicamente a tradição dos custos de transação e a 'agency theory', de Jensen \& Meckling. Na nova escola, apesar de não aprofundado por Rutherford, incluem-se Douglass North, ganhador do Prêmio Nobel de Economia de 1993, e Peter Evans, com aprofundamento de alguns dos temas supracitados, assim como reflexões da abordagem institucional comparativa.

Para North (1990), as instituições modelam a interação humana e afetam a eficiência econômica, na medida em que reduzem as incertezas e promovem uma estrutura para o funcionamento do cotidiano. A grande questão, portanto, seria que as instituições definem e limitam escolhas individuais, podendo, se houver funcionamento adequado, gerar melhor eficiência econômica.

Já Evans (2007), mais do que propriamente definir a noção de instituição, delineia duas questões centrais: o monocultivo institucional e o desenvolvimento deliberativo, a partir de instituições deliberativas. As teorias do desenvolvimento, segundo o autor, descansam sobre a premissa de um monocultivo institucional, entendido pelo prisma de que a eficiência das instituições não repousa sobre uma adequação ao entorno sociocultural local, e mais, que a importação das instituições idealizadas anglo-estadunidenses por si representam uma via de desenvolvimento, indiferente da posição do país na economia global. Evans (idem) tece uma série de críticas ao monocultivo institucional, dentre as quais podemos citar a que nas últimas décadas do século $X X$, em que houve esforços para impor 'boas instituições' nos países do Sul, os mesmos países que as adotaram seriam os que teriam apresentado as melhores taxas de crescimento econômico; fato incorreto, já que o crescimento da renda per capta nos países em desenvolvimento foi de 2,5\% entre 1960 e 1979, enquanto entre 1980 e 1998 permaneceu próximo de zero, (Easterly, 2001, apud Evans, op. Cit.).

O exemplo da China, que obteve nesse período supracitado elevados índices de crescimento econômico e é alvo de inúmeras especulações e 
críticas, nos parece muito emblemático nessa discussão. Mitos e explicações equivocadas sobre esse tema vão sendo vinculados tanto nos meios midiáticos, como acadêmicos. Neste sentido, Qian (2001) procurou estabelecer uma série reflexões sobre o crescimento econômico chinês, pautadas, sobretudo, nas reformas ocorridas nas últimas décadas. Questões relacionadas com investimentos externos, instituições, concentração das principais atividades econômicas no litoral, liberalização econômica, federalismo fiscal, entre outras, foram abordadas pelo autor. Nosso intuito é centrar a discussão nas práticas institucionais, já que estas receberam grande aporte de críticas e sugestões, das mais variadas agências internacionais, visando um modelo similar ao dos países desenvolvidos de 'boas práticas institucionais'. O argumento central é o de que esses modelos merecem cuidados e análises mais sérias, antes de serem efetivamente tomados como exemplo para todos os países em desenvolvimento.

Qian (idem:304) inicia sua discussão sobre as instituições relembrando aspectos centrais da Nova Economia Institucional baseada em três autores: Coase, 1992; North, 1997; e Willianson, 1994. Os argumentos levantados por esses autores são de que um bom mercado não é explicado apenas por bons preços, mas também pela garantia de propriedade privada e de 'boas instituições'. Significa dizer que reformas apontadas como fundamentais na globalização, como liberalização econômica, privatização e regulação podem até não ser eficientes, se não relacionadas com boas práticas institucionais que significam: garantias à propriedade privada; poder judiciário independente; regulação a favor de um mercado competitivo; governança corporativa; e sistema financeiro transparente. Porém, Qian vai questionar essas práticas utilizando os exemplos da China e da Rússia, que não realizaram essas reformas institucionais e, mesmo assim, tiveram um desenvolvimento econômico considerável.

Um dos principais argumentos utilizados pelo autor é o de que devemos pensar não naquilo que colocamos como formas ótimas de instituições, mas naquilo que é possível realizar em função da realidade de cada país estudado. Ou seja, na medida em que formulamos uma teoria, análises empíricas são 
fundamentais para sua comprovação, e, no caso da questão institucional, os indicadores e fatos nos remontam ao que o autor chama de transitional institutions, que seria a forma que esses países encontraram para promover mudanças econômicas que não, necessariamente, são as desejáveis pela teoria, mas sim as passíveis de realizar (op. Cit::307). No caso chinês, as reformas, mesmo fora dos modelos, seguiram as prerrogativas da eficiência econômica e da compatibilidade de interesses, esses foram os motivos de suas conquistas.

Chang (2004), outro autor crítico da economia institucional, realiza alguns apontamentos sobre os modelos impostos por países desenvolvidos, tanto no que diz respeito aos aspectos institucionais, quanto às políticas industriais. Segundo o autor, práticas como a proteção tarifária e os fomentos às indústrias nascentes foram adotadas por boa parte dos países avançados. Já no que diz respeito à questão institucional, Chang (idem) argumenta que as práticas de boa governança foram resultados e não causas do desenvolvimento, ou será mesmo que todos estão preparados para um Banco Central independente? É nesse sentido que o entendimento da estrutura das instituições e da economia dos países em desenvolvimento se revela como elemento fundamental para propostas de mudanças institucionais. No Brasil, por exemplo, hoje, questões vinculadas à educação e à capacidade de desenvolvimento tecnológico são muito mais urgentes do que a autonomia do Banco Central.

Aqui defendemos que países em desenvolvimento requerem modelos mais próximos das suas possibilidades, antes de medidas verticalizadas, desprovidas de adequação às suas realidades, o que também revela um aspecto da Geopolítica, já que pressupõe menor ingerência externa na definição das políticas nacionais. Nossa análise, portanto, pretende verificar as principais mudanças institucionais e legais tendo em vista as políticas de inovação, com foco, neste momento, nas possibilidades de financiamento, com ênfase no papel da FINEP e nas transformações relevantes da legislação brasileira que alteraram as possibilidades de indução à inovação no país. 


\subsection{Aspectos do financiamento à inovação tecnológica: o papel da FINEP e os marcos legais}

O ano de 2004 pode ser considerado um marco para as políticas de inovação no Brasil. Foi a partir dele que, tendo uma trajetória legal voltada aos financiamentos para ciência e tecnologia já desenvolvida e bem estruturada, o Brasil passou a contar com a possibilidade de financiamento público direto às empresas com projetos ligados à inovação.

As importantes mudanças legais que permitiram esse financiamento foram acompanhadas de transformações institucionais em órgãos que tiveram, originalmente, sua criação voltada ao financiamento de projetos ligados à ciência e tecnologia em centros de pesquisa públicos, universidades e outras instituições sem fins lucrativos. É nesse sentido que um resgate histórico institucional se torna fundamental.

Por ser a instituição que opera a Subvenção Econômica, as atenções aqui estarão voltadas às especificidades da FINEP, aos fundos operados por ela e às legislações diretamente relacionadas às possibilidades tanto de existência dos fundos, quanto de operação de financiamentos à esfera privada por parte da financiadora.

Inicialmente, a FINEP foi criada em 1965 como um fundo, o Fundo de Financiamento de Estudos e Projetos, ligado ao Banco Nacional de Desenvolvimento Econômico (BNDE), e seus objetivos estavam mais voltados à viabilização de estudos de programas e propostas de investimentos. Poucos anos depois, em 1967, esse fundo veio a se tornar uma empresa pública, que manteve a mesma sigla, mas com objetivo mais amplo: avaliar a viabilidade de projetos do Ministério do Planejamento (PIRRÓ E LONGO e DERENUSSON, 2009:517). A partir daí, a FINEP passou a ter papel central nas políticas de financiamento da C\&T no país.

No final da década de 1960, como relata Ferrari (2002:151) com base nos Relatórios Anuais da FINEP, já havia uma percepção da necessidade de 
expansão da base produtiva, sincronizada com uma revolução cientifica e tecnológica em curso em várias partes do mundo. Neste sentido, no ano de 1969, é criado, através do Decreto Lei $n^{0719}$, o Fundo Nacional de Desenvolvimento Científico e Tecnológico (FNDCT). Sua finalidade era exatamente dar apoio aos programas e projetos de C\&T para a implantação do Plano Básico de Desenvolvimento Cientifico e Tecnológico (PBDCT), que teria sua primeira versão promulgada em 1973. Quando do seu lançamento, o fundo previa um conselho diretor, constituído por representantes de diversos ministérios, além de instituições como o BNDES e o CNPq, e previa também a criação de uma Secretaria Executiva, que só veio a ser efetivada em 1971, pelo Decerto $n^{\circ} 68.748$, que delegou à FINEP essa função.

Com o desenvolvimento, sobretudo, de três programas, o de Apoio à Consultoria Nacional (ACN), o de Apoio ao Usuário dos Serviços de Consultoria (AUSC), e o Programa de Apoio ao Desenvolvimento Tecnológico da Empresa Nacional (ADTEN); a FINEP, que apoiava apenas empresas de consultoria, passou a operar "em todo o espectro do desenvolvimento científico e tecnológico" (idem:518). Segundo os mesmos autores, a simbiose entre o FNDCT e a FINEP foi, durante esses quarenta anos que se seguiram, "o mais poderoso instrumento de desenvolvimento científico e tecnológico" do país.

Durante a década de 1970, com recursos oriundos do Banco Interamericano de Desenvolvimento, o FNDCT teve fundamental importância para a consolidação de importantes instituições vinculadas ao sistema nacional de C\&T brasileiro, a exemplo da Comissão Nacional de Energia Nuclear (CNEN), uma das sete primeiras beneficiárias do fundo. Esse quadro seria mantido ainda na década de 1980, que, apesar da diminuição dos desembolsos, não foi tão ruim quanto na década que estava por vir, os anos 1990 (idem).

Até a década de 1990, um sistema voltado ao desenvolvimento científico e tecnológico havia sido criado no Brasil, com o fortalecimento de ICTs, mas o mesmo não pode ser afirmado quanto à inovação tecnológica nas empresas, salvo empresas públicas com setores de desenvolvimento tecnológico estruturado. Um dos poucos casos referentes a empresas privadas foi o das 
isenções fiscais previstas no Decreto-Lei 2.433/86. Porém, se observados o FNDCT e a própria FINEP, não encontraremos nenhum aporte para o setor produtivo privado.

No decorrer dos anos 1990, as iniciativas estruturais tomadas em direção a um sistema nacional de inovação mais efetivo não surtiram o mesmo efeito daquelas que surgiram nos anos 2000. É nesse sentido que um breve resgate se torna necessário, para que possa fazer sentido o papel que a FINEP passou a exercer nos últimos anos.

Quando analisamos a década de 1990, em que foram implementadas políticas econômicas mais ortodoxas, duas questões principais despontam como explicação para o fraco desempenho brasileiro em relação à inovação tecnológica: a ausência de políticas industriais e os cortes de gastos em áreas relacionadas à educação e P\&D. Obviamente que os cortes realizados foram, em grande parte, consequência da hiperinflação e da incapacidade de ajustes das contas públicas herdadas da década anterior. De qualquer forma, em termos de políticas diretamente voltadas ao setor produtivo, o período teve fraco desempenho.

Villaschi (2005) procurou captar quais foram as principais razões que levaram ao relativo 'abandono' das políticas de inovação. Inicialmente, o autor nos remonta à década de 1980 em que

- papel desempenhado pela empresas estatais e pelos laboratórios de pesquisa públicos em áreas que estavam no cerne do PTE (paradigma tecnológico-econômico) da TIC (tecnologias da informação e das comunicações) e a maneira como a tripla aliança entre empresas locais, estrangeiras e estatais vinha funcionando poderia ser uma indicação positiva de possibilidades

para o Sistema Nacional de Inovação Brasileiro. Porém, questões como o forte protecionismo, as altíssimas taxas inflacionárias e o déficit público reduziam 
sua eficiência e, quando entramos na década de 90, tivemos mudanças radicais do ponto de vista econômico.

A liberalização econômica não trouxe investimentos externos produtivos em áreas em que novos conhecimentos são fundamentais. $O$ setor farmacêutico pode ser um bom exemplo disso, já que os investimentos em PD\&I, até hoje, são realizados majoritariamente nos países de origem das empresas multinacionais, restando aqui processos simples como a embalagem, fato que contribuiu e ainda contribui com o crescente déficit na balança comercial do setor ${ }^{63}$. Outro ponto foi o corte de gastos em áreas essenciais como educação e P\&D, gerados pelo déficit público oriundo das décadas anteriores. E, por fim, a própria questão das empresas, que mantiveram estratégias defensivas quanto à inovação, mesmo aquelas localizadas em regiões mais dinâmicas do Brasil (VILLASCHI, 2005).

Outros fatores que incidiram direta e indiretamente sobre 0 desenvolvimento da inovação tecnológica foram levantados por Coutinho (2003). As altas taxas de juros e o câmbio sobrevalorizado se mostraram fundamentais para o aumento das importações, com destaque para máquinas, fato que afetou diretamente a promoção de políticas de inovação dentro das empresas, dado que boa parte das despesas era utilizada para essas compras. Não menos importante, também foi a fragilidade observada em setores de grande conteúdo tecnológico, já que muitas empresas foram compradas ou não conseguiram se manter competitivas em relação às empresas multinacionais.

É evidente que todos esses apontamentos, principalmente de cunho macroeconômico, tiveram relação com o fraco desempenho inovativo, tanto nas políticas de governo como no desenvolvimento de P\&D dentro das empresas. Por outro lado, não se pode perder de vista a atuação dos governos na condução de políticas para o setor produtivo. Nas palavras de Arbix e Mendonça (2005:255) no

\footnotetext{
${ }^{63} \mathrm{O}$ déficit na balança comercial do setor de medicamentos cresceu, só no período de 2000 2008, 130\% (CAPANEMA, PALMEIRA FILHO e PIERONI, 2008).
} 
início da década de 1990 a desarticulação da política de C\&T e da política industrial no Governo Collor não deixou espaço para políticas ativas, e a relação com o setor empresarial passou a ser regida pela introdução de instrumentos de política horizontais e pela visão de que a qualidade e a abertura de mercado resolveriam os problemas da competitividade.

Coutinho e Sarti (2003:334) estendem a falta de política industrial para a década de 1990 como um todo. Na visão desses autores, no período em questão "ocorreram apenas iniciativas isoladas, mas desintegradas e sempre contrariando a orientação macroeconômica e carecendo, ademais, de recursos significativos para promover seus objetivos". Ou seja, ficou evidente a fraca participação do Estado nas políticas de CT\&I, nesse período.

Porém, quando analisamos as experiências bem sucedidas de países que tiveram o desenvolvimento tecnológico como parte da política de desenvolvimento, a atuação do Estado aparece como princípio fundamental. Salerno e Kubota (2008:17) salientam que as atividades intensivas em conhecimento são de central relevância política, tendo em vista que "os governos, de todos os principais países do mundo, e daqueles aspirantes a tal posto, desenvolvem instrumentos de apoio ao desenvolvimento da ciência, da tecnologia e da inovação pelas empresas". Afinal, é inegável a importância da inovação tecnológica como fator de aumento da capacidade tecnológica, diminuição da dependência externa e da própria criação de melhores condições de trabalho e salários nas firmas (DE NEGRI, SALERNO e CASTRO, 2005).

A participação do Estado, através de incentivos para a inovação, é apontada como elemento central e utilizado por vários países, principalmente os desenvolvidos, como já ressaltamos no capítulo 1. Segundo Avellar (2008), os incentivos nesse sentido têm majoritariamente dois enfoques: no formato, como dedução do Imposto de Renda (que varia de caso a caso) ou crédito fiscal; ou no alvo, se será direcionado para pequena, média ou grande empresa. Um dos exemplos utilizados pela autora é o do Canadá, que apresenta um dos mais complexos e amplos sistemas de incentivos, que datam da década de 
1960, tendo diversas mudanças em seus conteúdos, incluindo incentivos locais (criados na década de 1970) para a inovação. E ganha destaque o fato de $40 \%$ das empresas no Canadá utilizarem alguma forma de incentivo, ainda muito superior ao nosso caso ${ }^{64}$.

No Brasil, mesmo sendo pequeno o número de empresas inovativas e as iniciativas de indução à inovação serem recentes, não podemos perder de vista a importância das últimas décadas rumo à consolidação de um sistema nacional de inovação mais robusto. Ainda na década de 1990, considerada como moderada nas políticas de inovação, tivemos o lançamento do Programa de Desenvolvimento Tecnológico Industrial (PDTI) em 1993. Esta iniciativa, baseada em incentivos fiscais, fundamentou-se no Decreto-Lei 2.433/86 e depois se consolidou, sem grandes alterações, pela Lei $n^{\circ}$ 8.661/1993. O estímulo à inovação, através dessa lei, até hoje se dá "por meio da dedução do IR e do crédito fiscal incididos no Imposto de Renda sobre Pessoa Jurídica (IRPJ), bem como no Imposto sobre Operações Financeiras (IOF)" (idem:333). Vale lembrar que esse programa ainda contou com uma ampliação no ano de 2002, em que foi criada a Lei 10.637, permitindo aos participantes o abatimento das despesas de custeio (relacionadas à pesquisa e inovação) do lucro líquido, para o cálculo do IR.

É importante frisar, no entanto, que no final da década de 1990, no segundo mandato do governo Fernando Henrique Cardoso, houve uma gradativa introdução da inovação na pauta das discussões sobre as reformas na condução das políticas de C\&T (PACHECO, 2005). Como ressaltado no capítulo anterior, tivemos a incorporação da inovação na II CNCTI e, no ano de 1999, a implementação daquele que seria o primeiro Fundo Setorial (FS), CTPeto, já que o FUNTTEL, previsto na Lei Geral de Telecomunicações, de 1997, só passou a valer a partir de 2002 (idem:8). De 2000 a 2003 foram implementados $14 \mathrm{FS}$, geridos pela FINEP, hoje temos $16 \mathrm{FS}$, sendo

\footnotetext{
${ }^{64} \mathrm{Em} 2006$ apenas $11 \%$ das empresas brasileiras utilizavam algum tipo de financiamento público, (MCT, CGEE, 2006).
} 
14 destinados a setores considerados estratégicos ${ }^{65}$ e dois às denominadas Ações Transversais.

$\mathrm{Na}$ teia dos incentivos, que não necessariamente se dão por isenções fiscais mas que estão diretamente relacionados à FINEP, a lei que mais nos interessa é a Lei n 10.973 de 2004, chamada de Lei da Inovação. Instituída como mais um mecanismo de melhoria do ambiente inovativo no Brasil, essa lei permitiu a subvenção econômica ${ }^{66}$ às empresas privadas, tipo de programa que até então não possuía aporte legal. Segundo o Artigo 19 da referida lei, as empresas nacionais passam, então, a poder receber incentivos da União, das ICTs e das agências de fomento para desenvolvimento de produtos e processos inovadores, "mediante concessão de recursos financeiros, humanos, materiais ou de infraestrutura". Além dessa novidade, fica claro, no próprio artigo supracitado, que os incentivos devem atender às prioridades da política industrial e tecnológica do país, principalmente nos que tange à melhoria da eficiência do setor produtivo e à capacitação tecnológica frente à competição externa, argumento com forte acepção geopolítica. E, como poderá ser observado no próximo item, as portarias ministeriais que definiram setores estratégicos para os editais da Subvenção Econômica estão em total consonância com as políticas industriais e tecnológicas lançadas nos últimos anos.

\footnotetext{
${ }^{65}$ Basicamente as receitas dos Fundos são oriundas de contribuições incidentes sobre o resultado da exploração de recursos naturais pertencentes à União, como, por exemplo, o caso - CTPetro, que destina $25 \%$ da parcela do valor dos royalties que exceder a $5 \%$ da produção de petróleo e gás natural; parcelas do Imposto sobre Produtos Industrializados de certos setores; da Contribuição de Intervenção no Domínio Econômico (CIDE) incidente sobre os valores que remuneram o uso ou aquisição de conhecimentos tecnológicos/transferência de tecnologia do exterior. Os FS estão divididos em: Ações Transversais; CT-Aero, CT-Agro; CTAmazônia; CT-Aquaviario; CT-Biotec; CT-Energia; CT-Espacial; CT-Hidro; CT-Info; CT-Infra (transversal também); CT-Mineral; CT-Petro; CT-Saúde; CT-Transporte; Verde Amarelo, dedicado à interação universidade-empresa. Todas as informações desta nota foram retiradas de http://www.finep.gov.br/fundos_setoriais/fundos_setoriais_ini.asp?codSessaoFundos=1, acesso em 13.03.2011.

${ }^{66}$ Segundo Guimarães (2008:177) "a Lei $n^{\circ} 10.637$, aprovada em 2002, ampliava os incentivos então existentes. Paralelamente, a Lei $n^{\circ} 10.332$, do mesmo ano, autorizava a concessão de subvenção econômica a empresas engajadas" do PDTI e PDTA. Vale ressaltar que essas leis não permitiam a subvenção na maneira como é realizada hoje.
} 
A própria visão do Ministério da Ciência e Tecnologia ${ }^{67}$ é reveladora de uma maior integração entre os mecanismos de indução à inovação, tanto os legais, como os dados pela política industrial. Abaixo, encontra-se um resumo do MCT sobre o marco regulatório pautado em três vertentes:

- I - Constituição de ambiente propício às parcerias estratégicas entre as universidades, institutos tecnológicos e empresas. Através da estruturação de redes e projetos internacionais de pesquisa tecnológica; ações de empreendedorismo tecnológico e criação de incubadoras e parques tecnológicos.

- II - Estímulo à participação de instituições de ciência e tecnologia no processo de inovação. Facilita a participação de ICTs em contratos de transferência de tecnologia e licenciamento de patentes, prestação de serviços em atividades do setor produtivo e participação de seus funcionários em projetos onde a inovação seja o foco.

- III - Incentivo à inovação na empresa. Estimular alocação de recurso financeiros das empresas para promoção da inovação. Concessão, por parte da União, das ICT e das agências de fomento, de recursos financeiros, humanos, materiais ou de infraestrutura, para atender às empresas nacionais envolvidas em atividades de pesquisa e desenvolvimento. Mediante contratos ou convênios específicos tais recursos serão ajustados entre as partes, considerando ainda as prioridades da política industrial e tecnológica nacional.

Paralela a essa consolidação legal, ainda tivemos a promulgação de mais uma lei de grande relevância, a Lei do Bem. Em realidade, essa lei, por causa da revogação da Lei $n^{\circ}$ 8.661/93, foi promulgada como Lei $n^{0} 11.196$ em novembro de 2005. Entre suas características pode-se dizer que, por um lado, fortaleceu o novo marco legal instituído pela Lei de Inovação, e, por outro, consolidou os incentivos fiscais para o usufruto de pessoas jurídicas de forma automática em empresas com investimentos em pesquisa tecnológica e inovação. Além disso, segundo Salerno e Kubota (2008:35), essa lei "introduz

${ }^{67}$ Informações disponíveis no sitio: http://www.mct.gov.br/index.php/content/view/8477.html, acesso em 22.11.2010. 
uma ruptura conceitual de largas proporções: os incentivos fiscais para P\&D são de fruição automática, não exigindo, portanto, que se apresente projeto ou que se peça autorização prévia para que possam ser usufruídos", agilizando e permitindo maior alcance dos incentivos. Os principais incentivos fiscais são dados pelos benefícios do Capitulo III, expostos abaixo:

- deduções de Imposto de Renda e da Contribuição sobre o Lucro Líquido CSLL de dispêndios efetuados em atividades de P\&D;

- redução do Imposto sobre Produtos Industrializados - IPI na compra de máquinas e equipamentos para P\&D;

- depreciação acelerada desses bens;

- amortização acelerada de bens intangíveis;

- redução do Imposto de Renda retido na fonte incidente sobre remessa ao exterior, resultante de contratos de transferência de tecnologia;

- isenção do Imposto de Renda retido na fonte nas remessas efetuadas para o exterior destinadas ao registro e manutenção de marcas, patentes e cultivares.

Pode-se observar acima uma extensão maior dos incentivos à inovação dada pela lei. Por outro lado, apesar da sua importância, ainda hoje a adesão das empresas é muito baixa no Brasil. A Tabela 1 deixa clara a afirmativa anterior, pois mostra o número de empresas cadastradas para receber os incentivos da lei. Apesar do crescente uso das isenções fiscais, tanto no Brasil, como um todo quanto em cada região, apenas 552 empresas aderiram, em 2008. Quando regionalizamos esses dados, a situação fica ainda mais complicada; afinal, juntas, as regiões Centro-Oeste, Nordeste e Norte não somam nem $10 \%$ do total de empresas cadastradas para receber os incentivos fiscais. Quantitativamente, esse fato será mais bem detalhado no próximo item, em que procuramos fazer o cruzamento das empresas que usufruem das isenções fiscais e da subvenção ao mesmo tempo. 


\section{Tabela 1}

Número de Empresas Cadastradas na 'Lei do Bem' por Regiões por ano

\begin{tabular}{lccc}
\hline & \multicolumn{3}{c}{ Ano } \\
\hline Regioões/Brasil & 2006 & 2007 & 2008 \\
\hline Sudeste & 73 & 192 & 310 \\
Sul & 52 & 120 & 204 \\
Centro-Oeste & 1 & 1 & 1 \\
Norte & 1 & 3 & 10 \\
Nordeste & 3 & 16 & 27 \\
Total & 130 & 332 & 552 \\
& & &
\end{tabular}

Fonte: MCT (2008)

Ainda que o número de empresas participantes do exemplo anterior seja baixo, deve ficar claro que houve um aumento das possibilidades geradas pelas mudanças legais, o que, por sua vez, gerou uma readequação de instituições, como a FINEP, para o atendimento de novas demandas.

Se olharmos para década de 1990, tanto no que se refere aos incentivos fiscais quanto aos próprios recursos oriundos do FNDCT, não se pode negar que os avanços subsequentes tiveram dimensões significativas. De meados dos anos 1980 até o fim da década de 1990, esse fundo contou com receitas consideradas moderadas para tal finalidade, ou seja, em média, de US $\$ 50$ milhões. O que também não diminui sua importância, haja vista seu papel fundamental no desenvolvimento de projetos como o do avião Tucano da Embraer $^{68}$, o programa de formação de recursos humanos da Embrapa e os projetos da Petrobrás (FINEP, 2004:5). De qualquer forma, em 1997, com o objetivo de aumento das alternativas para a captação de recursos, foi proposta a vinculação dos royalties do petróleo para áreas definidas como prioritárias e a criação de instrumentos normativos, bem como medidas provisórias e projetos de lei, que não vinculassem essas receitas para o fundo com as receitas oriundas de impostos. Estruturadas suas fontes de recursos, o fundo tenderia a ter uma crescente natural. Porém, se analisados os recursos do FNDCT, que já

\footnotetext{
${ }^{68} \mathrm{O}$ exemplo da Embraer é extremamente emblemático sobre o caráter de longo prazo nas políticas de inovação. Como ao longo da tese estamos dando ênfase à consolidação das políticas de incentivo à inovação, retomaremos esse caso apenas nas conclusões.
} 
vinham crescendo durante a década de 1990, os desembolsos, em 1999, foram de aproximadamente $R \$ 190$ milhões, chegando, em 2006, a cifras próximas de $R \$ 790$ milhões.

Neste quadro de aumento das receitas e das próprias funções, tendo em vista a expansão dos programas de apoio à CT\&I, a FINEP passa a ser elemento crucial no sistema nacional de inovação, gerindo não só os recursos do FNDCT como também o programa Juros Zero, entre outros. Ou seja, esse espectro de funções mais amplo, que passou também a credenciá-la como instituição de financiamento para empresas privadas, merece toda atenção quanto aos seus atributos internos e mecanismos de avaliação de suas atividades.

Em relação às suas atribuições, segundo o Relatório de Gestão de 2009, dada a importância do programa de subvenção e a crescente demanda, a FINEP não só diminuiu o número de fases de apresentação de propostas, de duas para uma, com o intuito de centralizar as operações, assim como criou uma diretoria exclusiva para o tratamento dos assuntos relacionados ao programa, a Diretoria de Subvenção Econômica (DSBV). É relevante também a iniciativa da Diretoria de Inovação e do Departamento de Acompanhamento da FINEP, que realizou um relatório com base em entrevistas feitas com 27 empresas contratadas pela Subvenção Econômica, exatamente para avaliação de suas atividades. O estudo procurou analisar a efetividade do uso dos recursos da financiadora, assim como entraves e aspectos positivos do financiamento. Esse relatório pode ser visto como um exemplo da busca por uma melhora institucional, já que se preocupa com a avaliação e abre a possibilidade e mudanças que podem ser sugeridas pelas partes diretamente envolvidas no processo de financiamento.

É de se esperar que essa mudança institucional da FINEP, assim como o programa de subvenção às empresas, possa contribuir para o desenvolvimento do país e, sobretudo, para a diminuição da dependência tecnológica externa ${ }^{69}$. Porém, ainda nesta seção, julga-se necessária a

\footnotetext{
${ }^{69}$ Almeida (2009) realizou um estudo sobre a eficácia da política industrial e tecnológica do governo Lula. Entre suas conclusões, há especial atenção para o fato da política não ter surtido
} 
discussão do tema das compras públicas, tão importante para as políticas de inovação, às quais ainda não está integrado de maneira efetiva. Por mais que seja inegável o avanço das políticas federais de incentivos e isenções, do ponto de vista legal o país ainda apresenta um gargalo importante a ser corrigido: a lei de normas para licitações e contratos de Administração Pública, Lei 8.666.

Na referida lei, o único caso em que se verifica privilégio, por parte do poder público, na contratação de serviços de empresas que desenvolvem tecnologia no Brasil, é no $2^{\circ}$ parágrafo do artigo $3^{\circ}$. O artigo em questão, em realidade, só se aplica no caso de igualdade de condições entre empresas que participam do processo licitatório, ou seja, só assim é assegurada a preferência de aquisição de bens e serviços produzidos ou prestados por empresas brasileiras de capital nacional; produzidos no País; produzidos ou prestados por empresas brasileiras e produzidos ou prestados por empresas que invistam em pesquisa e no desenvolvimento de tecnologia no País. É importante ressaltar que essa vantagem só é assegurada quando em condições de igualdade e não em outras situações, como beneficiar empresas que desenvolvam projetos de inovação com financiamentos e incentivos do governo ou mesmo que apenas realizem inovações capazes de diminuir importações de determinado segmento econômico.

A prática do poder de compra do Estado vem sendo muito questionada e vista como um mecanismo eficiente na promoção de políticas de inovação; porém, conforme explicitado acima, ainda vetado ao uso no país pela própria legislação brasileira. Elder e Georghiou (2007) realizaram um estudo sobre as potencialidades e efetividades do uso desse mecanismo. Entre algumas conclusões, os autores ressaltaram que os usos das compras públicas são mobilizadores de inovação, eles podem, por um lado, melhorar a qualidade das políticas públicas, e, por outro, melhorar os serviços ofertados à população. Ao citar os exemplos da União Européia e da China, os autores afirmam que as

o efeito esperado, dado o aumento do déficit na balança comercial, sobretudo ligado aos setores de alta e média tecnologia. É inegável esse aumento no déficit, porém os resultados de uma política industrial e tecnológica não são esperados nos anos seguintes aos seus lançamentos, ou seja, os resultados costumam ocorrer no médio e longo prazo, ficando ainda muito incipiente uma conclusão negativa sobre a efetividade da política. 
compras públicas têm sido utilizadas como parte da política de inovação, nesse último país, quando as compras dizem respeito a produtos ligados à inovação. Por fim, a argumentação é no sentido de não confundir compras públicas com processo de 'picking-winner strategy' ${ }^{70}$, já que este define empresas ou tecnologias para serem alavancadas. No caso das compras ${ }^{71}$, o importante é escolher áreas do mercado consideradas estratégicas para o desenvolvimento de processos inovativos.

No Plano de Ação (PACT\&I) 2007-2011, essa questão já é mencionada:

Este instrumento será mobilizado para promover o desenvolvimento tecnológico das empresas brasileiras, tanto por intermédio da compra direta de produtos e processos inovadores (como permitido pela Lei de Inovação), quanto pelo estabelecimento de contrapartidas de acesso a tecnologias na aquisição pelo governo, no exterior, de significativos lotes de produtos ou serviços. Alguns segmentos se afiguram preferenciais. Por exemplo, a indústria de produtos farmacêuticos surge como uma das primeiras áreas de aplicação desse instrumento, devido ao considerável porte das compras públicas no mercado nacional para esses produtos; e à importância deles para a saúde pública e, por último, ao fato desse setor ter sido incluído entre os prioritários da PITCE.

(BRASIL, 2007a:52)

É importante fazer essa menção, dada a relevância que o tema tem apresentado nas discussões sobre as políticas de inovação e, na própria visão do atual governo, de necessidade de integração da política de compras com as políticas de incentivos à inovação. Porém, não se pode negar que efetivos

\footnotetext{
${ }^{70}$ As críticas a esse modelo advêm do fato da escolha ser baseada em empresas já competitivas, fazendo com que "PMEs (pequenas e médias empresas) estejam subrepresentadas no grupo de empresas apoiadas" (IEDI, 2010).

71 Segundo Elder e Georghiou (2007:953): "We can distinguish general procurement practice versus strategic procurement, direct public procurement (where the goods or services are exclusively for public use) versus catalytic procurement and, finally, commercial versus precommercial procurement".
} 
avanços ainda não podem ser observados na legislação brasileira, mesmo com as alterações realizadas em dezembro de $2010^{72}$.

De qualquer forma, a discussão deve ser acompanhada de transformações institucionais capazes de não permitir usos incorretos, como o de favorecimento de grupos empresariais ou de grupos políticos ligados às compras governamentais. E, por outro lado, é fundamental não perder de vista que se trata de uma forma de indução à inovação permitida pelas regras comerciais internacionais, tendo inclusive um manual adotado pela União Européia (EUROPEAN COMMISSION, 2007).

A prática do poder de compra do estado, se aliada a um financiamento como a subvenção econômica, pode se tornar uma ferramenta de grande efetividade na condução da melhoria do quadro da inovação no Brasil. No próprio documento do Plano de Ação do MCT há um item exclusivo sobre o uso do poder de compra do estado, como parte do Programa de Inovação Tecnológica nas Empresas, apontando para a "necessidade do aperfeiçoamento do marco legal e da segurança jurídica na aplicação dos instrumentos e de esforço ainda maior para a consolidação e o aperfeiçoamento dessa política" (BRASIL, 2007a:43). A argumentação presente no documento também relata exemplos, como o dos Estados Unidos, de uso do poder de compra incluindo apenas ressalva para empresas de residentes no país, mesmo que não sejam de base tecnológica, e pequenas empresas. Para o atual estágio das políticas de inovação no Brasil, as mudanças legais se configuram como fundamentais, sobretudo para viabilizar e dar maior escopo aos financiamentos públicos e, sem dúvida, o uso do poder de compra se configura como elemento central desse processo, o que aprofundaria ainda mais a Geopolítica da inovação tecnológica.

\footnotetext{
${ }^{72}$ A Lei 8.666 já sofreu alteração, quanto a suas atribuições, pela Lei 12.349/2010. O parágrafo $6^{\circ}$ prevê preferência nas compras em caso de desenvolvimento tecnológico e inovação feitos no país. Porém, alterações ainda estão sendo realizadas, como evidenciamos no artigo publicado no jornal Valor Econômico, dia 17 de março de 2011, intitulado "Área de saúde terá dispensa de licitação". No artigo em questão, o secretário de Ciência, Tecnologia e Insumos Estratégicos do Ministério da Saúde, Carlos Gadelha, afirma estar em negociação com o MDIC para a dispensa licitatória das companhias que produzem medicamentos de alto custo e alta complexidade, vacinas, testes para identificar doenças transmissíveis e equipamentos médicos, no país. É incipiente, portanto, analisar essas alterações, já que permanecem em curso.
} 


\subsubsection{Uma análise da Subvenção Econômica da FINEP}

Feitas as apreciações institucionais e legais, a partir de agora se iniciam as análises das questões quantitativas e qualitativas ligadas à Subvenção Econômica. Conforme explicitado na introdução, os dados utilizados fazem parte de uma compilação de estatísticas feita pelo IPEA, porém, para ilustrarmos alguns pontos da evolução da política, utilizamos também as informações da publicação do resultado final da SELEÇÃO PÚBLICA MCT/FINEP/FNDCT Subvenção Econômica à Inovação - 01/2009. Fato que não nos permite análises mais aprofundadas para o mesmo ano, mas exibe um panorama mais amplo.

Além de uma descrição dos contratos por ano, procurou-se avaliar outras questões importantes, como: sua distribuição espacial; sua distribuição por áreas estratégicas; sua distribuição em relação ao porte das empresas participantes; e o cruzamento entre as empresas contratadas pela Subvenção com outras linhas de fomento à inovação, fato que, se verificado, nos daria indícios de que as políticas de inovação estariam acontecendo de forma integrada. Por fim, procurou-se, a partir do porte das empresas e da localização nos estados brasileiros, estabelecer um perfil das empresas participantes do programa.

O panorama geral da Subvenção Econômica pode ser visto na tabela abaixo: 
Tabela 2

Valores e Número de Projetos da Subvenção Econômica por ano

\begin{tabular}{lccccc}
\hline & 2006 & 2007 & 2008 & 2009 & Total \\
\hline \multicolumn{1}{c}{ Valores (R\$ milhões) } & & & & & \\
\hline Disponível & 300 & 450 & 450 & 450 & 1650 \\
Adicional & 0 & 0 & 64 & 17 & 81 \\
Aprovado & 274 & 313,8 & 514 & 466 & 1567,8 \\
Não executado & 26 & 136,2 & 0 & 0 & 162,2 \\
Projetos $\left(\mathrm{n}^{\circ}\right)$ & & & & & \\
Solicitados & 1099 & 2567 & 2664 & 2558 & 8888 \\
Aprovados & 145 & 174 & 245 & 261 & 825 \\
\hline
\end{tabular}

Fonte: FINEP

Como se pode observar na Tabela 2, o padrão que deveríamos esperar para o programa, ou seja, aumento do número de projetos solicitados e valores aprovados constantes, não foi verificado. No ano de 2006, o edital previu recursos para o financiamento da ordem de $R \$ 300$ milhões. Destes, $R \$ 26$ milhões não foram executados. Em seguida, os recursos previstos subiram para $\mathrm{R} \$ 450$ milhões, mas, em 2007, o programa não executou o total disponibilizado, sobrando, para o mesmo período, obviamente, uma considerável quantia, superior aos R\$ 136 milhões. Já em 2008 e 2009, os valores aprovados subiram consideravelmente, contando com recursos superiores aos previstos nos editais. Segundo consta no 'Relatório de Gestão FINEP 2008', o valor adicional de R\$ 64 milhões, no mesmo ano, foi uma decisão da própria instituição, com base no acórdão $n^{\circ} 2876 / 2008$, do Tribunal de Contas da União (TCU).

Um fato, particularmente, chama atenção: a queda tanto do valor total contratado em 2009 quanto dos projetos solicitados, saindo um pouco da lógica esperada, pois, com o passar dos anos, a tendência seria de que um maior número de empresas participasse do processo seletivo. Uma das hipóteses que pode ser levantada é que um conjunto de fatores - a saber, a concorrência dada pelo crescente número de participantes nos anos anteriores, o aumento da contrapartida exigida às grandes empresas e a burocracia demandada pelo processo todo de seleção - constituem elementos desmotivadores às empresas. Por outro lado, o fato da FINEP ter alterado a chamada pública em apenas uma fase, como mencionado na seção anterior, também pode contribuir com a 
explicação, afirmação que só poderia ser feita caso houvesse comprovação empírica.

Segue-se que o valor global da Subvenção, de mais de $\mathrm{R}$ \$ 1,5 bilhão, e o número total de projetos que participaram do processo seletivo, 8888, são consideráveis e dão indício de uma política que, em termos de alcance, tem possibilidades de bons resultados.

Quanto à continuidade do programa de subvenção, segundo o 'Plano Plurianual (PPA) 2008-2011' do MCT, há previsão de orçamento do FNDCT para a Subvenção Econômica até o ano de 2011, ainda que até meados de 2010 o edital de subvenção não tenha sido lançado. A previsão de recursos é próxima dos valores anuais, cerca de $\mathrm{R} \$ 477$ milhões por ano. Esse montante representaria cerca de $21 \%$ do total de gastos previstos pelo FNDCT para os anos de 2010 e 2011.

A questão da distribuição territorial dos recursos segue a concentração das atividades de ciência e tecnologia no país, ou seja, forte participação das regiões Sul e Sudeste, com destaque para o Estado de São Paulo ${ }^{73}$. Em todos os editais havia menção da obrigatoriedade de destinação de $30 \%$ dos recursos para as regiões Centro-Oeste, Nordeste e Norte, mas no mesmo item havia também uma ressalva: caso não haja projetos classificados, os recursos poderão ser aplicados em outros projetos recomendados para aprovação. $\mathrm{O}$ Gráfico 1 evidencia não só a concentração nas destinações dos recursos como também explicita que, em nenhum dos quatro anos do financiamento, as regiões que deveriam ter parcelas garantidas sequer chegaram perto de obter os $30 \%$ de direito. Apenas no ano de 2007 é que tivemos um aumento da participação da região Nordeste, mas que voltou a cair nos anos seguintes; além disso, a participação conjunta das regiões CO e N não atingiu os $30 \%$.

\footnotetext{
${ }^{73}$ A partir de duas fontes de dados é possível verificar a extrema discrepância do estado de São Paulo, em contraponto com outras Unidades da Federação. Segundo CGEE (2010), os recursos aplicados em C\&T, em relação à receita total no estado de São Paulo, em 2008, eram de $3,67 \%$ e o gasto total de C\&T em porcentagem do PIB estadual, 0,39\%. Para se ter uma ideia, o segundo estado com maior participação nas duas variáveis é o Paraná com, respectivamente, $2,67 \%$ e $0,26 \%$. Já para a FAPESP (2010), que contabilizou também a participação das instituições federais e das empresas, o dispêndio total em P\&D no estado foi de aproximadamente $1,52 \%$ do PIB Estadual, em 2008, ficando à frente não só do Brasil, como da Espanha e da Índia, entre outros.
} 
É importante atentar para a relação entre a porcentagem de empresas contratadas e o valor do contrato por região. Para as regiões $\mathrm{CO}, \mathrm{N}, \mathrm{NE}$ e S a porcentagem de empresas contratadas é sempre maior do que os valores, o que revela uma participação ainda menor dessas regiões nos valores contratados em proporção à participação das empresas. Apenas na região SE é que a porcentagem das empresas é menor que o valor contratado, o que indica que os projetos aprovados dessa região são mais caros do que os projetos das outras. Isso se verifica quando analisamos os dez maiores contratos em todos os anos, incluindo 2009; dos 40 maiores projetos 24 são de empresas localizadas em São Paulo, somando, aproximadamente, R\$ 238 milhões, sendo o Rio de Janeiro o segundo estado mais significativo, (com apenas três empresas e cerca de $\mathrm{R} \$ 37$ milhões).

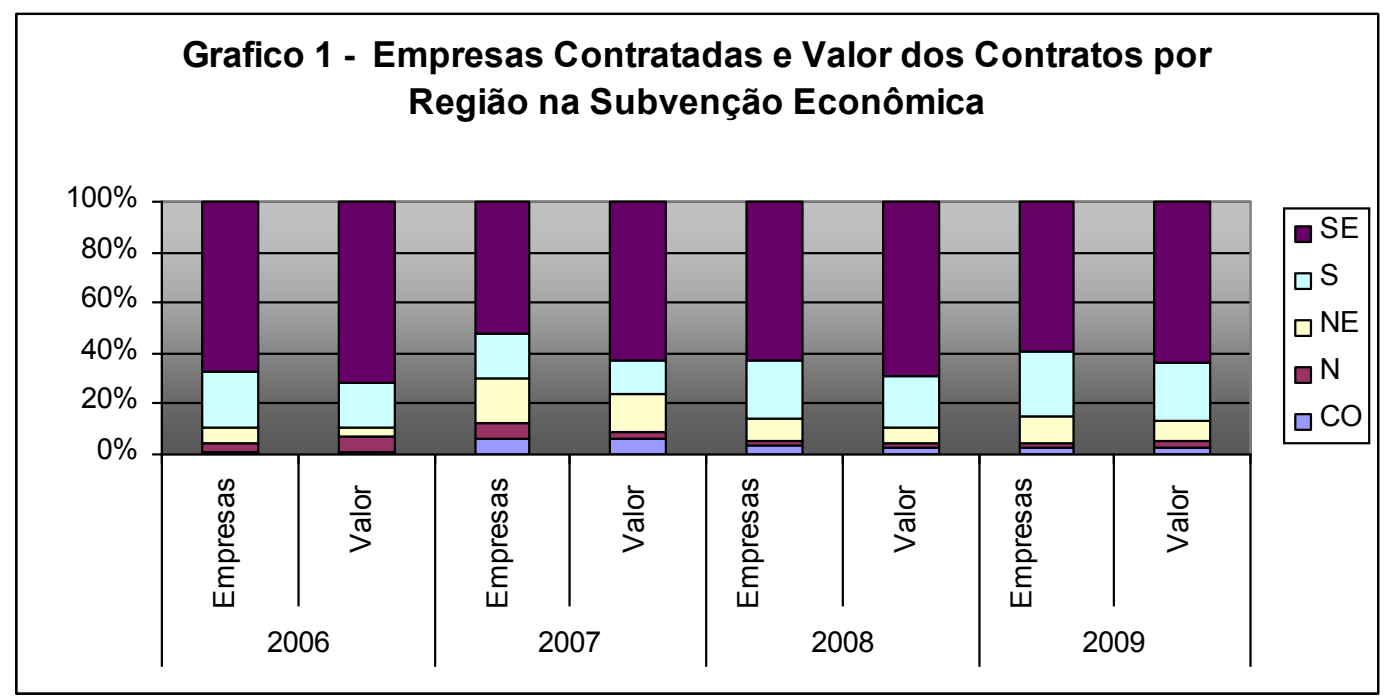

Fonte: FINEP

Um fundo não reembolsável, obviamente, é de interesse de qualquer empresa, mesmo que para sua obtenção haja alto grau de burocracia ou qualquer outra negatividade. Afinal, "os mecanismos destinados a financiar investimentos em inovação tecnológica são diferentes daqueles voltados ao financiamento convencional, principalmente por conta dos riscos envolvidos e do tempo de retorno, que tendem a ser maiores" (CORDER E SALLES-FILHO, 2006:36), o que torna esse tipo de financiamento escasso. Dito isso, diferente de um financiamento para aquisição de máquinas ou realização de melhorias 
na infraestrutura, a inovação trata de um modelo que apresenta um conjunto de riscos e, portanto, não seria correto um financiamento para esse fim sem o estabelecimento de critérios e, mais importante, áreas de interesse, setores que tivessem real importância para que fossem contemplados, de maneira a poder contribuir com o desenvolvimento do país ${ }^{74}$. E é neste sentido que todos os editais foram definidos em consonância com a política industrial e tecnológica do Brasil. A maneira através da qual isso se tornou possível foi o estabelecimento de áreas estratégicas, todas previstas como prioritárias na PITCE, PDP ou PACT\&I. Em relação às áreas, observam-se alterações ao longo dos anos, porém, hoje, já se encontram de forma mais delimitada e clara, tanto para as empresas, quanto para os próprios responsáveis pela seleção dos beneficiados.

As áreas prioritárias do primeiro edital foram definidas com base na portaria ministerial MCT/MDIC $n^{\circ} 597$. À época houve total consonância com a PITCE, afinal os setores estratégicos da política eram: software, bens de capital, fármacos e medicamentos. Se observada a portaria interministerial supracitada, as prioridades para a subvenção, segundo os parágrafos $2^{\circ}$ e $3^{\circ}$, eram duas: áreas estratégicas, como semicondutores, software, bens de capital, fármacos e medicamentos; áreas portadoras de futuro como biotecnologia, nanotecnologia e biomassa/energia alternativa. Na seleção dos projetos de 2006, segundo os dados da FINEP disponíveis no banco de dados do IPEA, os critérios tiveram como base áreas que iam desde as claramente estabelecidas como aeroespacial, bens de capital, biotecnologia, energias alternativas, fármacos e medicamentos, nanotecnologia e TV Digital; passando por áreas que contemplavam diferentes setores, como 'Aplicações Mobilizadoras Estratégicas', que incluíam Tecnologias da Informação e Comunicação (TIC), defesa, saúde, educação, agronegócio e 'Geral', que, além das sete áreas claramente estabelecidas, também acabou por contemplar adesivos, engenharia, arquitetura, indústria cerâmica, madeira, móveis e têxtil.

Observou-se que, apesar de termos tido alguns setores definidos, nesse ano houve uma flexibilidade maior nas propostas e no desembolso de contrato

\footnotetext{
${ }^{74}$ Incluindo o fato da Subvenção Econômica ser possível, segundo as normas da OMC, para atividades de CT\&I.
} 
para áreas não diretamente ligadas à política industrial, a exemplo de 'cerâmica', fato que, como veremos a seguir, não viria a repetir-se nos outros anos. Exatamente por esse motivo, para os anos seguintes, algumas análises estatísticas com base na definição das áreas estratégicas foram realizadas, o que não foi possível em 2006, sobretudo por essa diversidade de temas.

A partir de 2007, houve uma padronização maior em relação à definição de áreas e temas prioritários. Basicamente, todas as áreas que seriam vigentes para os anos de 2008 e 2009 estavam contempladas em 2007. Suas definições foram feitas com base nas Portarias Ministeriais 597, de 2006, e 554, de 2007. Porém o texto do edital é exatamente igual ao da portaria de 2007. Uma análise um pouco mais aprofundada dos editais nos leva a afirmar que a política, a partir desse ano, já foi definida de maneira mais clara quanto seus objetivos, tendo apenas pequenas mudanças no conteúdo das áreas estratégicas, como evidenciado no acréscimo do setor de energia eólica ${ }^{75}$ na área de 'Energia', em 2009, já que até esse ano o edital priorizava apenas o desenvolvimento de tecnologias voltadas aos bicombustíveis, em geral, e às tecnologias ligadas a cana-de-açúcar, em particular.

Além de reservar uma área estratégica ligada ao desenvolvimento de tecnologias sociais, chama atenção o fato de, em 2008, nas definições mais especificas da área da saúde, termos tido menção á integração da política de inovação com o SUS, já que o segundo item do edital explicita o "desenvolvimento de moléculas com alto potencial no campo sanitário e/ou impacto nos gastos do Sistema Único de Saúde (SUS)". O que torna claro o direcionamento ainda maior das políticas de inovação para uma integração com as políticas sociais, elemento de extrema relevância na definição de prioridades em C\&T.

Finalizando essa breve descrição, nos anos de 2008 e 2009 a única mudança foi a passagem da área de 'Programas Estratégicos' para 'Defesa Nacional e Segurança Pública', o que não altera de maneira significativa seu conteúdo. Afinal, as prioridades foram dadas a projetos ligados ao

\footnotetext{
${ }^{75} \mathrm{O}$ total de projetos aprovados para a área de 'Energia' foi de 26, dos quais 16 são para desenvolvimento de tecnologias ligadas à produção de energia eólica.
} 
desenvolvimento de sistemas de navegação, a materiais específicos (alta densidade e emissores de pósitrons) do setor, assim como a tecnologias aeroespaciais.

De maneira geral, podemos afirmar que a definição das áreas estratégicas seguiu um padrão de consonância com as políticas industriais e de inovação do país, sempre procurando estabelecer, sobretudo com o passar dos anos, aspectos cada vez mais específicos para as áreas estratégicas, de maneira a conferir um importante aspecto geopolítico.

Em relação à distribuição dos recursos pelas áreas, desde o primeiro edital havia previsão de distribuição equitativa por todas as áreas, exceto 'Desenvolvimento Social' que teve, em todos os anos, uma porcentagem inferior dos recursos. O que se nota no Gráfico $2^{76}$ é que houve concentração em algumas áreas, a não ser em 2008, quando se observa uma melhor distribuição dos recursos pelas áreas, ainda que não se possa falar em uma boa distribuição. Da mesma forma, com base nos dados, se torna complicado chegar a alguma conclusão, sobretudo pela irregularidade da distribuição nesses primeiros anos. A área de 'Biotecnologia' é emblemática nesse sentido, pois de uma participação de $4,7 \%$, em 2007 , sobe abruptamente para $20,8 \%$, em 2008, e volta a 5,9\%, em 2009, ou seja, parece que ainda não há critérios claramente definidos para a seleção dos projetos por áreas, mesmo estando previstos nos editais, o que indica uma variação do próprio conteúdo das propostas. A ressalva fica por conta das áreas de 'Saúde', que se mantiveram em uma crescente ao longo dos anos, e de 'Programas Estratégicos', que, apesar da queda em 2008, mantiveram sempre o maior quinhão dos recursos aprovados.

\footnotetext{
${ }^{76}$ Para fins de análise, as áreas foram definidas conforme a nomenclatura do ano de 2008. Algumas ressalvas são importantes: em 2007, a área 'Saúde' estava dispersa em outras áreas, sendo assim, procuramos na variável 'classificação' apenas os projetos vinculados à palavra 'saúde'; em 2009, a área 'Programas Estratégicos' foi modificada para 'Defesa Nacional e Segurança Pública', porém houve apenas pequenas alterações pontuais nos objetivos.
} 


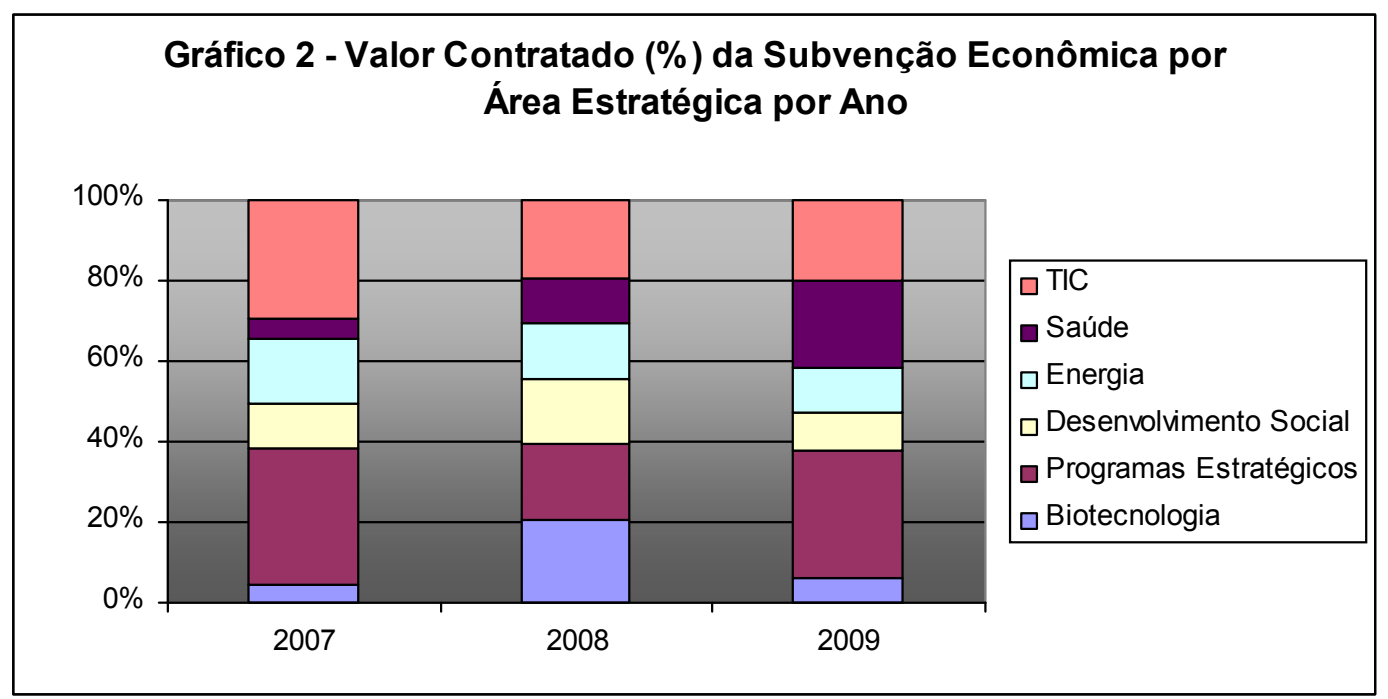

Fonte: FINEP

A última análise, antes de entrarmos nas questões relativas à sobreposição de financiamentos para inovação, é em relação ao porte das empresas contratadas. O critério adotado pela FINEP para realizar a distinção das empresas por porte foi o do 'MERCOSUL', que se baseia no faturamento anual: Microempresa e Pequeno Porte até R\$ 2,4 milhão; Pequena Empresa entre $\mathrm{R} \$ 2,4$ milhão e $\mathrm{R} \$ 10,5$ milhões; Média Empresa entre $\mathrm{R} \$ 10,5$ milhões e $\mathrm{R} \$ 60$ milhões e Grande Empresa mais de $\mathrm{R} \$ 60$ milhões.

Apesar da quebra de padrão no ano de 2007, o que se verifica é uma clara tendência à diminuição da participação de empresas de grande porte e ao aumento da presença de microempresas/pequeno porte e pequena empresa (ver Gráfico 3). Isso é visível também quando analisamos os maiores projetos financiados pelo programa. Afinal, projetos com valores superiores a $R \$ 10$ milhões deixam de existir em 2009. A queda de participação das grandes empresas é drástica, pois, em 2009, obtiveram apenas $6,4 \%$ do valor contratado.

A explicação para a mudança no padrão da política, ou seja, do fortalecimento das micro e pequenas empresas, está no fato da contrapartida financeira ${ }^{77}$ exigida pela financiadora ter se mantido para microempresa e

\footnotetext{
${ }^{77}$ A contrapartida financeira exigida é a porcentagem em relação ao valor aprovado pela subvenção.
} 
pequeno porte em $5 \%$, e para pequena empresa em $20 \%$, enquanto para média e grande empresa subiu, respectivamente, de $40 \%$ para $100 \%$ e de $60 \%$ para $200 \%$. Esses dados demonstram claramente que a FINEP nada mais fez do que acompanhar a PDP, lançada em 2008, que deixava explícita a necessidade de fomentar a inovação em empresas de menor porte e, para tal, dificultou em muito o acesso das grandes empresas ao financiamento, já que a cada $R \$ 100$ requeridos a contrapartida seria de $R \$ 200$. Se por um lado o foco dos incentivos em empresas de menor porte tem suas justificativas, como ser um instrumento de incentivo à inovação em empresas sem capacidade financeira para tal, o incentivo às grandes empresas também pode exercer um papel fundamental em tecnologias de ponta e setores estratégicos, como o de defesa, que requerem grandes aportes financeiros.

O Gráfico 4 indica a diminuição considerável do desembolso para grandes empresas em 2008, relatada acima, pouco mais de $10 \%$, assim como sua considerável participação no total da contrapartida financeira, em mais de $40 \%$.

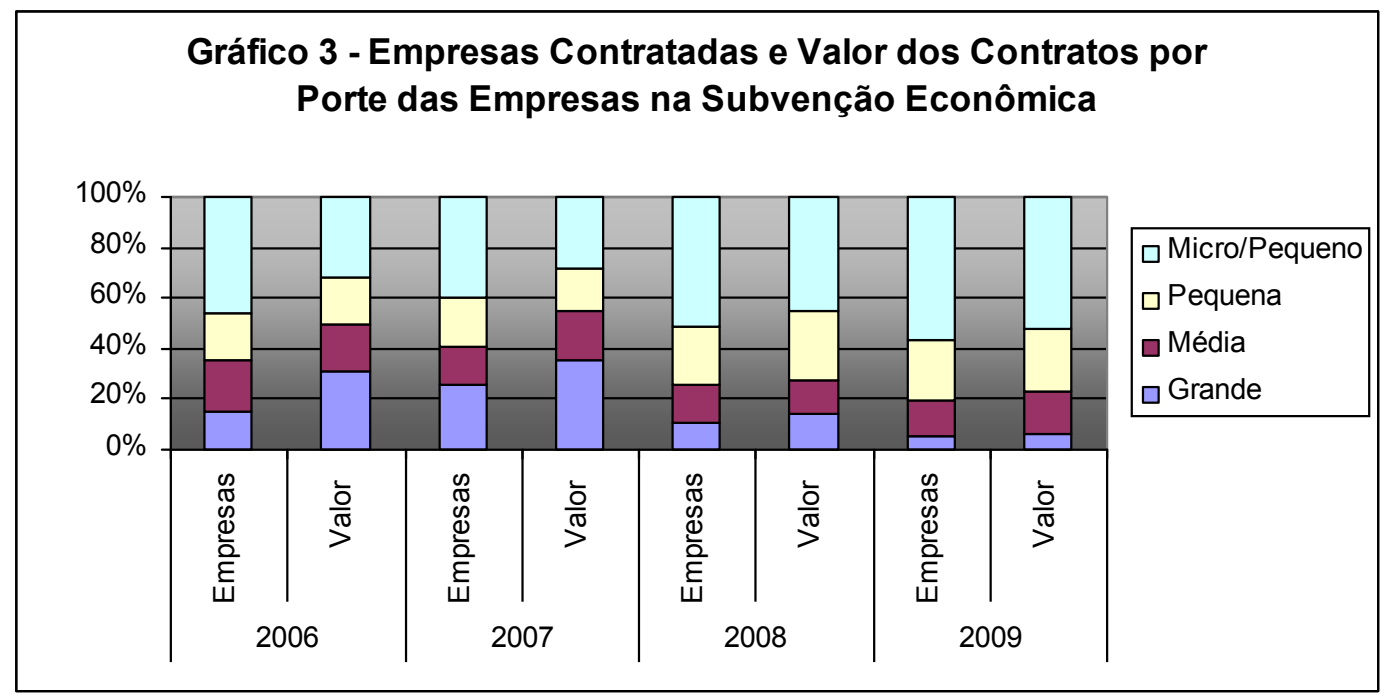

Fonte: FINEP 


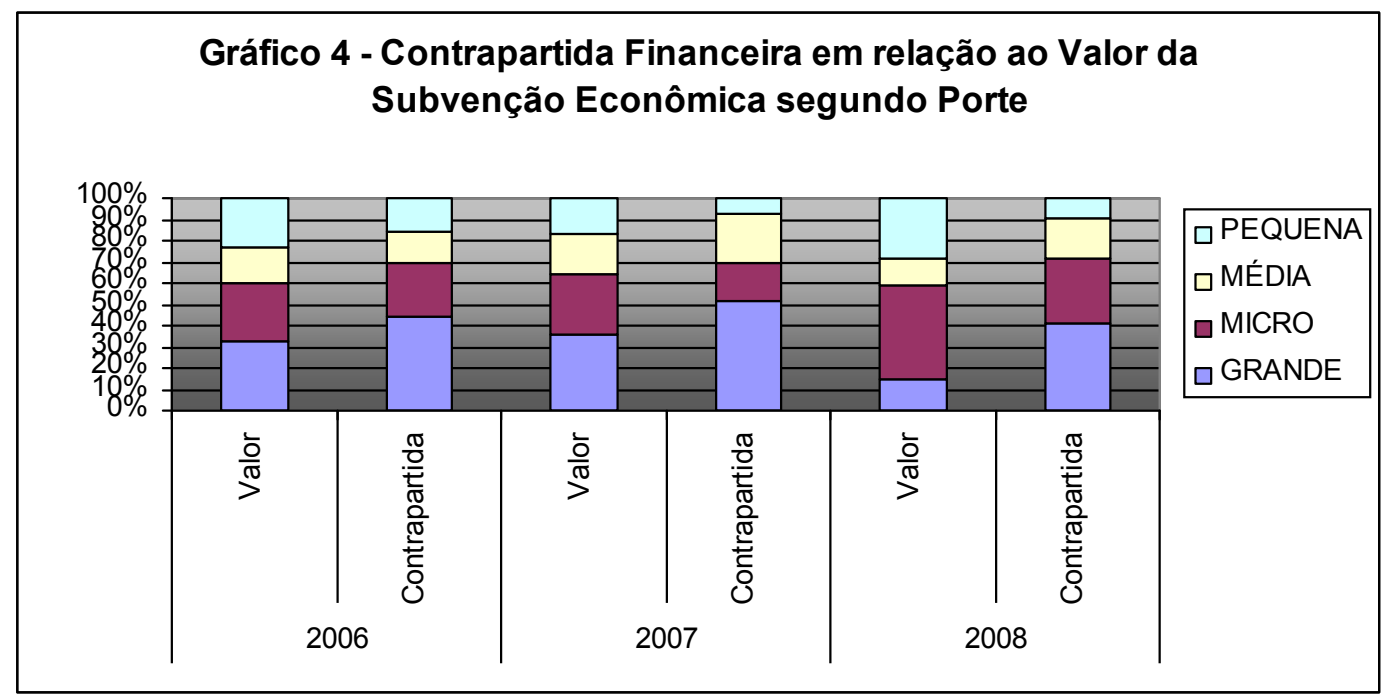

Fonte: FINEP

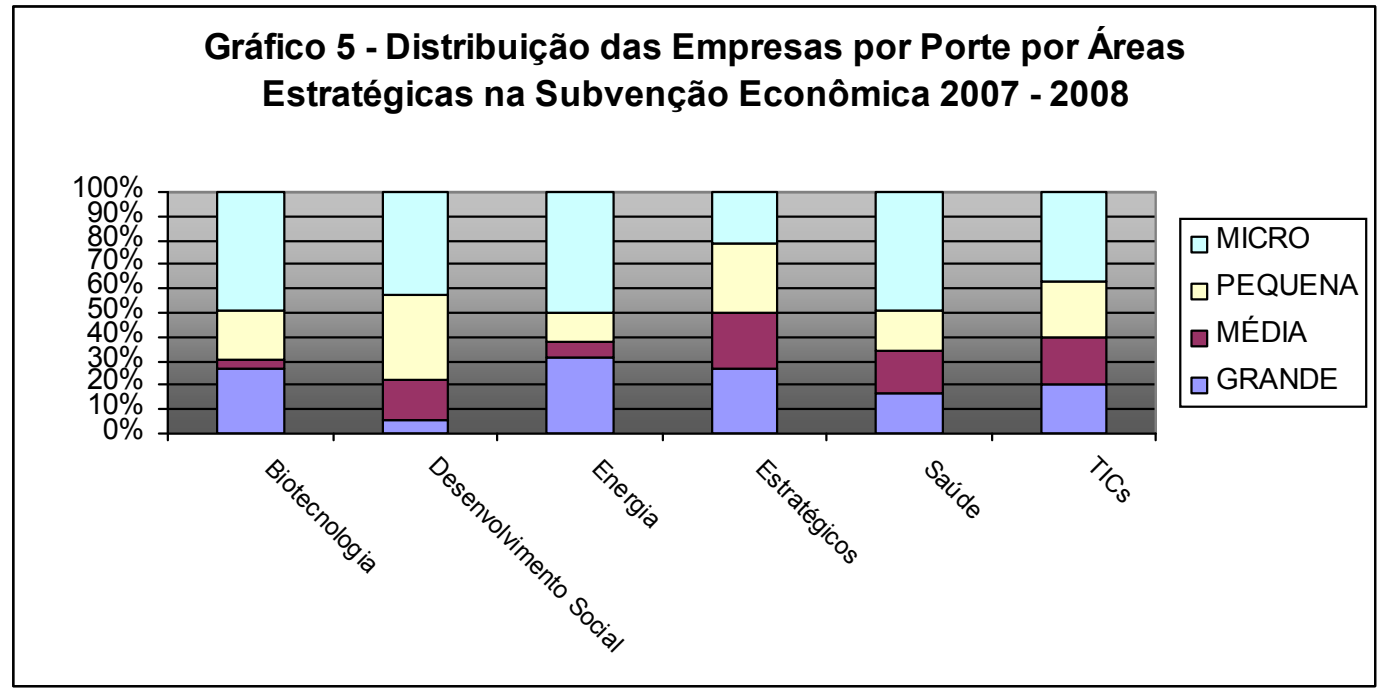

Fonte: FINEP

Por fim, o Gráfico 5 revela a distribuição das empresas por porte em função das áreas estratégicas. As que ganham destaque, em relação às grandes e médias empresas, são energia e estratégicos, sendo esta última a única em que basicamente $50 \%$ dos desembolsos se destinam a grandes e médias empresas. Isso se justifica pelos elevados investimentos necessários para inovação em áreas como a aeroespacial e a de defesa. Já os setores que tiveram perfil de empresas participantes parecidos foram: biotecnologia, saúde e TICs. Teoricamente, deveríamos esperar também a participação de empresas de maior porte na saúde, porém o setor só veio a ser diretamente 
contemplado em $2008^{78}$, ano em que já prevalecia a contrapartida maior. Participação realmente pouco significativa de grandes empresas foi verificada no setor de desenvolvimento social, com maior concentração de micro e pequenas.

A partir deste momento, passaremos a verificar o grau de inter-relação da subvenção com outras políticas de incentivo à inovação. Arbix (2007) ressaltou a necessidade de "definir estratégias que permitam coordenar ações de desenvolvimento social com objetivos de promover a inovação e o conhecimento preservando a visão de longo prazo". Quanto às recomendações, Arbix (idem) afirmou ser fundamental desenvolver no interior da PITCE um programa de fomento às inovações empresariais em tecnologias de alto impacto econômico e social, assim como repensar e readequar os instrumentos de fomento, de financiamento e de incentivos fiscais para torná-los mais eficientes no estímulo à inovação empresarial, em especial, compatibilizando a legislação de incentivos fiscais e integrando sua gestão (entre setores e nos três níveis federativos), de maneira a construir um sistema nacional de crédito e financiamento para todas as modalidades de C\&T\&I, articulado com o BNDES, a FINEP e Fundos Setoriais. O que, no nosso caso, poderia ser evidenciado pela utilização e conhecimento de incentivos pelas empresas contratadas da subvenção nas diversas instituições fomentadoras de inovação, assim como seu conhecimento de incentivos fiscais para inovação.

Uma das questões inicialmente pensadas foi como seria a articulação das empresas contratadas pela FINEP com outras linhas de fomento à inovação do governo federal. Nesse sentido, a preocupação foi entender se, de alguma forma, a existência de outros mecanismos de fomento eram conhecidos ou utilizados pelas empresas contratadas pela FINEP. Ou seja, se a empresas tinham alguma institucionalidade em relação à busca de outras formas de financiamento à inovação, sobretudo porque o projeto exigido no modelo de subvenção é extremamente complexo, o que teoricamente colocaria a empresa em condições de solicitar outros fomentos e indicaria que as linhas de financiamento do governo são conhecidas e articuladas. Como houve

${ }^{78}$ No ano de 2007, não havia uma área específica para a saúde, esta encontrava-se contemplada junto com biodiversidade e biotecnologia. 
cruzamento de bancos de dados distintos, não foi possível uma padronização de todas as informações ${ }^{79}$. É importante deixar claro que os cruzamentos foram realizados com base em todas as empresas contratadas nos três primeiros anos de subvenção e com as bases históricas disponíveis para os outros incentivos. Ou seja, a relevância procurada foi se, em algum momento, a empresa contratada pela FINEP já utilizara outra forma de incentivo, mesmo que em anos passados. Um exemplo pode ser dado pela empresa ' $X{ }^{80}$ que participou de dois projetos vinculados aos Fundos Setoriais em 2001 e 2004, respectivamente, e também foi contemplada com três projetos na subvenção econômica, em 2006 e 2007. A seguir, dar-se-á início às análises.

O primeiro cruzamento foi feito entre as empresas contratadas na Subvenção e as empresas que participaram de projetos dos Fundos Setoriais (FS).

\footnotetext{
${ }^{79}$ O melhor exemplo é o cruzamento entre as bolsas do CNPq e da Subvenção Econômica da FINEP. O banco de dados da primeira instituição não contém o CNPJ das empresas, o que dificultou o cruzamento, já que em cada banco a razão social pode conter diferenças de grafia.

${ }^{80}$ Preferimos deixar em sigilo o nome da empresa.
} 
Tabela 3 - Empresas participantes da Subvenção Econômica da FINEP e dos Fundos Setoriais até 2008

\begin{tabular}{cccc}
\hline Fundo & $\begin{array}{c}\text { Empresas } \\
\text { Valor FINEP } \\
(\mathrm{R} \$)\end{array}$ & $\begin{array}{c}\text { Valor Fundo } \\
\text { Setorial }(\mathrm{R} \$)\end{array}$ \\
\hline CT-AERONAUTICO & 7 & $122.049 .632,35$ & $90.900 .062,29$ \\
CT-AGRONEGÓCIO & 0 & $\cdot$ & $\cdot$ \\
CT-AMAZÔNIA & 0 & $\cdot$ & $\cdot$ \\
CT-AQUAVIÁRIO & 5 & $10.914 .131,52$ & $3.608 .374,88$ \\
CT-BIOTECNOLOGIA & 2 & $4.747 .251,11$ & $1.506 .600,00$ \\
CT-ENERGIA & 6 & $9.877 .824,84$ & $2.239 .795,83$ \\
CT-ESPACIAL & 1 & $3.954 .594,00$ & $249.400,00$ \\
CT-HIDRO & 1 & $500.000,12$ & $201.600,00$ \\
CT-INFO & 22 & $39.072 .655,43$ & $10.030 .581,61$ \\
CT-INFRA-ESTRUTURA & 0 & $\cdot$ & $\cdot$ \\
CT-MINERAL & 0 & $\cdot$ & $\cdot$ \\
CT-PETRÓLEO & 8 & $25.277 .016,44$ & $4.539 .574,56$ \\
CT-SAÚDE & 0 & $\cdot$ & $\cdot$ \\
CT-TELECOMUNICAÇÃO & 0 & $\cdot$ & $\cdot$ \\
CT-TRANSPORTE & 0 & & $\cdot$ \\
CT-TRANSVERSAL & 64 & $213.014 .860,88$ & $80.643 .692,20$ \\
CTFTEL & 11 & $37.417 .146,39$ & $45.953 .190,83$ \\
FNDCT & 7 & $25.898 .708,38$ & $5.806 .857,66$ \\
OUTFON & 7 & $12.912 .327,67$ & $5.705 .289,82$ \\
VERDE E AMARELO & 15 & $136.581 .571,19$ & $24.313 .849,35$ \\
\hline
\end{tabular}

Fonte: FINEP

Obs: os cruzamentos foram realizados com as empresas que acessaram, até o ano de 2008, simultaneamente a Subvenção Econômica e os fundos setoriais, mesmo que o acesso tenha ocorrido em anos diferentes.

A análise da Tabela 3 indica que nos FS houve predomínio de participação de empresas contratadas na Subvenção no CT-TRANSVERSAL e CT-INFO. O primeiro parece ser mais óbvio, afinal trabalha em articulação com os outros fundos e foi concebido apenas no ano de 2004. Mas o que podemos perceber é que de todos os cruzamentos, esse - FS - foi um dos que apresentou maior número de empresas contempladas nos dois financiamentos. O fato de serem geridos pela mesma instituição é um indicativo de um conhecimento maior das possibilidades de financiamento da mesma, até porque as informações ficam disponíveis em um mesmo sítio, na página da FINEP na web. Vale a pena observar também que os desembolsos da 
subvenção foram sempre consideravelmente superiores aos do FS, a não ser no caso do CT-AERONAUTICO, em que os valores foram muito próximos.

O outro grande cruzamento que verificamos diz respeito às oito modalidades do BNDES, ver Tabela 4. Nele encontramos um número considerável de empresas da Subvenção que buscaram algum tipo de financiamento do BNDES. Chama a atenção, sobretudo, a modalidade Máquinas e Equipamentos, que infelizmente não distingue, no banco de dados, investimento para P\&D. A modalidade de Mercado de Capital nos chamou a atenção, já que se esperava um número maior de empresas ligadas à Subvenção e que teriam sido capitalizadas pelo programa BNDES Parceiro (BNDESPAR), porém, quando analisados os dados, encontramos uma pequena adesão de empresas da Subvenção nessa modalidade. Em outras operações mais difundidas, como Financiamento à Empresa e BNDES Automático, seria de se esperar uma participação maior das empresas da Subvenção, fato representado na tabela abaixo:

Tabela 4 - Empresas participantes da Subvenção Econômica da FINEP e das Modalidades BNDES

\begin{tabular}{|c|c|c|c|}
\hline Modalidade & Empresas & $\begin{array}{c}\text { Valor BNDES } \\
(\mathrm{R} \$)\end{array}$ & $\begin{array}{c}\text { Valor FINEP } \\
(\mathrm{R} \$)\end{array}$ \\
\hline Financiamento a Empresa & 33 & $255.310 .202,62$ & $4.710 .320,90$ \\
\hline Máquinas e Equipamentos & 62 & $457.282 .062,00$ & $9.125 .657,70$ \\
\hline BNDES - Exim & 17 & $384.010 .136,41$ & $45.920 .238,70$ \\
\hline Mercado de Capitais & 8 & $83.437 .544,37$ & $516.910,30$ \\
\hline Aval & 0 & . & \\
\hline Não Reembolsável & 0 & . & \\
\hline Financiamento ao Fabricante & 2 & $9.913 .264,00$ & $191.409,90$ \\
\hline BNDES Automático & 40 & 262.713.710,99 & $26.279 .608,40$ \\
\hline
\end{tabular}

A existência de um programa para inovação no CNPq levou ao interesse pelo cruzamento de dados dele com a Subvenção. O fato de ser uma agência tradicionalmente voltada ao fomento de atividades em universidades e centros de pesquisa chamou atenção. O programa com o qual foi realizada a sobreposição foi o de Formação de Recursos Humanos em Áreas Estratégicas 
(RHAE), criado em 1987, e que tinha suas atribuições geridas pelo MCT. Porém, após algumas mudanças, em 1997, ele ficou sob responsabilidade do CNPq e, a partir de 2002, passou a ser chamada de RHAE-Inovação. Com base no banco de dados da referida bolsa, para os anos de 2004 a 2008, procuramos as empresas da Subvenção que acessaram esse fomento. $O$ número de empresas foi relativamente pequeno, não chegando nem a $10 \%$ do total das empresas contratadas na subvenção (ver Tabela 5). A finalidade de servir sobretudo às micro, pequenas e médias empresas foi constatada, sendo, a maioria dos casos, de microempresas. Porém, é representativo o fato do valor dos projetos aprovados para subvenção para as microempresas ser de aproximadamente $\mathrm{R} \$ 51$ milhões, muito acima do valor dos desembolsos para as microempresas da RHAE, que é cerca de $\mathrm{R} \$ 8,8$ milhões.

\footnotetext{
Tabela 5 - Empresas participantes da Subvenção Econômica da FINEP e da bolsa RHAE

\begin{tabular}{|c|c|c|c|c|}
\hline \multirow[b]{2}{*}{ Porte Empresa } & \multicolumn{2}{|c|}{ FINEP } & \multicolumn{2}{|c|}{ CNPq RHAE } \\
\hline & Valor $(\mathrm{R} \$)$ & $\begin{array}{c}N^{\circ} \text { de } \\
\text { empresas }\end{array}$ & Valor $(\mathrm{R} \$)$ & $\begin{array}{c}N^{\circ} \text { de } \\
\text { empresas }\end{array}$ \\
\hline Microempresa & $51.246 .291,00$ & 26 & $8.864 .505,00$ & 26 \\
\hline Pequena & $12.503 .635,00$ & 6 & $2.333 .166,00$ & 6 \\
\hline Total & $63.749 .925,00$ & 32 & $11.197 .671,00$ & 32 \\
\hline
\end{tabular}

Fonte: FINPE, CNPq/RHAE

Por fim, realizamos o cruzamento das empresas contratadas na Subvenção com as empresas participantes da 'Lei do Bem' (ver Tabela 6). O total de empresas aprovadas na subvenção e que utilizam a 'Lei do Bem' ainda é pequeno, se levado em conta o fato dessas empresas terem um, mesmo que pequeno, setor de P\&D. Porém, quando analisamos a sobreposição dos outros instrumentos com a Lei do Bem, os resultados da subvenção não são tão
} díspares. 


\begin{tabular}{|c|c|c|}
\hline Porte & $\begin{array}{c}\mathrm{N}^{\circ} \mathrm{de} \\
\text { Empresas }\end{array}$ & $\begin{array}{c}\text { Valor FINEP } \\
(\mathrm{R} \$)\end{array}$ \\
\hline Grande & 27 & $174.178 .181,00$ \\
\hline Média & 10 & $73.991 .906,00$ \\
\hline Pequena & 3 & $12.656 .189,00$ \\
\hline Micro & 1 & $3.954 .594,00$ \\
\hline Total & 41 & $264.780 .870,00$ \\
\hline
\end{tabular}

Segundo De Negri et al. (2010:19), que também realizou uma sobreposição de instrumentos para inovação, o maior grau de sobreposição entre os instrumentos foi observado entre a 'Lei do Bem' (incentivos fiscais) e os projetos reembolsáveis (crédito). As conclusões do estudo apontam que é

razoável supor que exista uma complementaridade importante entre esses dois mecanismos: os incentivos fiscais reduzem o custo associados ao processo de inovação, mas não garantem que as empresas tenham, no momento do investimento, os recursos necessários para investir no projeto de $P \& D$, o que é feito por meio de mecanismos de crédito.

No caso da Subvenção, apesar de não reembolsável, a sobreposição entre as empresas contratadas e as beneficiárias da Lei do Bem revelou uma participação ainda tímida, em torno de $9 \%$ das empresas. Já nas linhas do BNDES, créditos para aquisição de máquinas e equipamentos foi o que mais apresentou sobreposição, cerca de $14 \%$. O que por sua vez, condiz com as estatísticas realizadas por De Negri et al. (idem).

As últimas análises desse item são referentes ao perfil das empresas sob três perspectivas: por Unidades da Federação (UF); pelo porte e, por último, por comparação entre empresas contratadas da subvenção com as contratadas pelos $\mathrm{FS}$ e as presentes na RAIS. Os dados foram compilados com base na RAIS e na SECEX. Em função de ainda não haver resultados 
disponíveis nos bancos de dados citados para o ano de 2008, utilizamos os dados de 2007, para as empresas contratadas na Subvenção em 2008.

Em relação ao perfil das empresas contratadas na Subvenção por UF, ver Tabela 7, os resultados demonstram uma variedade de situações, ou seja, conclusões sobre o perfil das empresas com base no desenvolvimento dos estados são impraticáveis para as empresas contratadas na Subvenção. Um primeiro exemplo pode ser o Rio de Janeiro, que detém os valores mais baixos em relação ao número de patentes e às exportações e, ao mesmo tempo, apresenta a terceira média mais elevada de pós-graduandos empregados nas empresas. 
Tabela 7 - Perfil das Empresas Contratadas na Subvenção Econômica da FINEP por UF 2006, 2007 e 2008 - Média de Contratos, Pessoal Ocupado com Terceiro Grau e Pós Graduação, Renda, Faturamento, Número de Patentes, Valor Exportado

\begin{tabular}{|c|c|c|c|c|c|c|c|c|}
\hline UF & Número de Empresas & Contratos & Terceiro Grau & Pós Graduação & Renda & Faturamento Mensal & Número de Patentes & Valor Exportado \\
\hline AM & 13 & 331.4 & 67.9 & 0 & 1,412 & $7,832,796$ & 0 & $14,478,271$ \\
\hline CE & 14 & 26.7 & 15 & 0.1 & 1,044 & 400,285 & 0 & 0 \\
\hline PB & 3 & 15.1 & 2.8 & 0.3 & 759 & 122,126 & 0 & 0 \\
\hline PE & 17 & 92 & 31.8 & 0.1 & 1,301 & $1,594,589$ & 0 & $1,934,910$ \\
\hline BA & 9 & 339.3 & 157.9 & 6.6 & 2,608 & $21,129,163$ & 0.6 & $109,295,274$ \\
\hline MG & 41 & 288.8 & 73.1 & 0.9 & 1,440 & $12,069,223$ & 0 & 93,325 \\
\hline RJ & 39 & 67.3 & 37.7 & 1.9 & 2,291 & $2,678,073$ & 0 & 94,311 \\
\hline SP & 165 & 300.8 & 118.1 & 1 & 2,584 & $14,015,121$ & 0.2 & $45,026,250$ \\
\hline PR & 27 & 172.9 & 42.4 & 0.5 & 1,400 & $2,800,211$ & 0.1 & $8,697,992$ \\
\hline SC & 34 & 321.1 & 78 & 0.7 & 1,660 & $7,189,811$ & 0.1 & $5,279,904$ \\
\hline RS & 37 & 191.8 & 39.9 & 0.8 & 1,684 & $3,843,897$ & 0.1 & $3,659,341$ \\
\hline GO & 7 & 25.4 & 7.7 & 0 & 982 & 298,095 & 0 & 15,023 \\
\hline DF & 7 & 438.7 & 272.1 & 0.1 & 1,819 & $16,611,009$ & 0 & 31,470 \\
\hline
\end{tabular}


Tabela 8 - Perfil das Empresas Contratadas na Subvenção Econômica da FINEP por Porte -Número de Empresas, Média de Contratos por ano, de Pessoal Ocupado com Terceiro Grau e Pós Graduação, Número Médio de Patentes, Valor Médio Exportado (R\$), Valor Finep (R\$), Contrapartida Fin anceira (R\$), Faturamento Médio (R\$) - 2006, 2007 e 2008

\begin{tabular}{|c|c|c|c|c|c|c|c|c|c|}
\hline Porte & $\begin{array}{l}\text { Número de } \\
\text { Empresas }\end{array}$ & $\begin{array}{l}\text { Contratos } \\
\text { no Ano }\end{array}$ & $\begin{array}{l}\text { PO Terceiro } \\
\text { Grau }\end{array}$ & $\begin{array}{l}\text { PO Pós- } \\
\text { Graduação }\end{array}$ & Patentes & Valor Exportato & Valor Finep & $\begin{array}{l}\text { Contrapartida } \\
\text { Financeira }\end{array}$ & Faturamento \\
\hline MICRO & 178 & 12.39 & 4.47 & 0.35 & 0.02 & $33,441.93$ & $1,717,710.95$ & $1,101,448.93$ & $1,752,995.15$ \\
\hline PEQUENA & 100 & 36.87 & 12.51 & 0.06 & 0.03 & $109,268.21$ & $2,000,207.91$ & $706,733.09$ & $13,173,296.63$ \\
\hline MÉDIA & 75 & 172.08 & 48.21 & 0.92 & 0.08 & $3,158,672.97$ & $2,349,790.39$ & $2,439,155.29$ & $49,395,339.75$ \\
\hline GRANDE & 69 & $1,177.32$ & 414.91 & 3.76 & 0.46 & $129,699,933.52$ & $3,532,891.86$ & $5,213,611.68$ & $2,545,895,786.74$ \\
\hline
\end{tabular}

Fonte: RAIS, SECEX.

Tabe la 9 - Comparação do Perfil das Empresas - RAIS, Fundos Setoriais e Subvenção Econômica FINEP - 2006, 2007,2008

\begin{tabular}{|c|c|c|c|c|c|c|c|c|}
\hline Grupo & $\begin{array}{c}\mathrm{N}^{\circ} \mathrm{de} \\
\text { Empresas }\end{array}$ & $\begin{array}{l}\text { Tamanho } \\
\text { médio }\end{array}$ & $\begin{array}{l}\text { Estudo } \\
\text { Médio }\end{array}$ & $\begin{array}{l}\text { Idade } \\
\text { Média }\end{array}$ & $\begin{array}{c}\mathrm{N}^{\circ} \\
\text { Exportad oras }\end{array}$ & $\begin{array}{c}\% \\
\text { Exportadoras }\end{array}$ & Patenteadoras & Patenteadoras \\
\hline FS & 1,664 & $1,457.70$ & 11.7 & 28.7 & 287 & $17.25 \%$ & 302 & $18.15 \%$ \\
\hline SUB & 433 & 412.4 & 11.6 & 15.3 & 132 & $30.48 \%$ & 93 & $21.48 \%$ \\
\hline
\end{tabular}

Fonte: RAIS, SECEX. 
De maneira geral, o perfil das empresas contratadas na subvenção não nos permite uma análise mais efetiva do financiamento por estado. Afinal, houve, para os três primeiros anos, uma irregularidade em relação às empresas participantes, tanto no que diz respeito aos desembolsos por estados, quanto por porte, vide variação considerável ao longo dos anos, sobretudo se observada a diminuição do contrato de grandes empresas no ano de 2008. O caso da Bahia é revelador. O estado, que detém médias de patentes e de exportação elevadas, merece atenção. O valor alto, sobretudo das exportações, diz respeito à participação de grandes empresas nos dois primeiros anos da subvenção e ao pequeno número de empresas contratadas, fato que diminui a participação de empresas de menor porte e, portanto, não 'dilui' os resultados, como no caso das empresas participantes de São Paulo.

De qualquer forma, as exportações indicam uma ainda baixa participação de empresas exportadoras na Subvenção Econômica. Na maior parte dos estados os valores são extremamente baixos, pois apenas Bahia, São Paulo e Amazonas têm médias de exportação superiores a R $\$ 10$ milhões.

Já a relação entre exportação e patentes, exceto no caso do Amazonas, apresentou forte conexão, sendo os estados que mais exportam os que têm maior média de patentes. Porém, isso não diminui a importância de se observar médias extremamente baixas de patentes nas empresas em todos os estados analisados.

Os dados relativos ao grau de instrução do pessoal ocupado também apresentaram variação considerável, dificultando a análise. O Distrito Federal, apesar de se configurar como a maior média de pessoal ocupado com terceiro grau, tem um percentual médio de pessoal ocupado com pós-graduação insignificante, de cerca de $0,1 \%$.

Se compararmos os graus de instrução com a renda média e a massa salarial, chegaremos à mesma variabilidade de situações. O que nos permite ressaltar que as empresas contratadas na Subvenção não oferecem análises regionalizadas relevantes. A hipótese é que, dada a amostragem ainda 
pequena de empresas e a participação de grandes empresas nos primeiros anos, a consequente grande variação do porte das empresas contratadas conduz a resultados desproporcionais, se os dados forem regionalizados.

Já a análise do perfil das empresas por porte seguiu uma tendência mais esperada. A observação do perfil das empresas por porte foi feita com base no banco de dados da FINEP, o que remete ao 'critério MERCOSUL' (explicitado anteriormente). A opção por não utilizar o critério do IBGE para indústria se deve ao fato de que nem todas as empresas contratadas no financiamento são industriais.

A análise da Tabela 8 traz resultados mais óbvios, ou seja, em todas as variáveis as maiores médias são relativas às empresas de grande e médio porte. As grandes empresas, sobretudo para as médias de 'valor exportado' e 'faturamento', são consideravelmente superiores, o que indica a participação de empresas realmente importantes nos seus nichos de mercado. Mesmo assim, é relevante observar que o número médio de patentes dessas empresas é relativamente pequeno, considerando os dados antes mencionados, o que indica uma política ainda tímida em relação às patentes no Brasil. Quanto ao valor FINEP para os três anos, ainda se verifica um maior aporte de recursos para as grandes empresas, como resultado dos grandes contratos nos dois primeiros anos de subvenção, situação que tende a se inverter dado o aumento da contrapartida exigida.

Porém, chamam atenção as variáveis de 'número de mestres e doutores' e 'contrapartida financeira' comparadas entre as micro e pequenas empresas. Nos dois casos, as micro empresas apresentam médias mais elevadas do que as pequenas, mesmo com faturamento médio mais de sete vezes superior aos das últimas. A justificativa se refere ao fato de apenas duas micro empresas, com números bem superiores nessas duas variáveis, aumentarem as médias, caso contrário, a tendência por porte seria mantida.

A comparação entre as empresas da Subvenção e as da RAIS e dos FS revelou dados interessantes, ver Tabela 9. As empresas participantes da Subvenção Econômica apresentam porcentagem de empresas exportadoras e 
com patentes superior à das outras duas amostragens, apesar do tamanho médio e do grau de instrução médio serem inferiores aos das empresas dos FS. Já na comparação de todas as variáveis, as empresas da Subvenção apresentaram capacidade de inovação muito superior à das participantes da RAIS, sobretudo se observadas as diferenças entre as variáveis de patentes e de exportação.

Os números relativos à Subvenção Econômica revelaram alguns aspectos interessantes, sobretudo uma variação ainda muito grande tanto nos parâmetros de seleção quanto das próprias empresas participantes, o que, por sua vez, proporciona resultados um pouco fora dos padrões esperados. De qualquer forma, as análises demonstraram um financiamento que vem se consolidando e se tornando cada vez mais estruturado do ponto de vista dos seus objetivos.

\subsubsection{Uma análise exploratória dos quinze maiores desembolsos da Subvenção Econômica}

No ano de 2010, foi realizada uma pesquisa de campo que objetivava entrevistar as quinze maiores empresas beneficiárias da Subvenção. O campo contou com financiamento do Instituto de Pesquisa Econômica Aplicada (IPEA), através do projeto "Fundos Setoriais e Sistema Nacional de Inovação: uma análise exploratória”, encomendado pelo Ministério de Ciência e Tecnologia ${ }^{81}$. A idéia inicial era, a partir de um roteiro estruturado (ver Anexo I), analisar questões qualitativas em relação à Subvenção. Por se tratar de entrevistas sobre projetos considerados estratégicos pelas empresas, nenhuma informação que não consta dos resultados dos editais da FINEP, e que, portanto, é pública, será individualizada, a não ser em uma análise sobre o caso de duas empresas que receberam desembolsos do programa, mas foram

\footnotetext{
${ }^{81}$ Os coordenadores João De Negri e Fernanda De Negri gentilmente cederam o material coletado para uso na presente tese.
} 
vendidas a uma multinacional. Abaixo segue a tabela das empresas entrevistadas:

Tabela 10 - Maiores financiamentos (R\$) da Subvenção Econômica de 2006, 2007 e 2008

\begin{tabular}{lcccc}
\hline \multicolumn{1}{c}{ Nome da Empresa } & Valor Finep & Porte & UFN de ProjetosEntrvista \\
\hline \hline EMBRAER - EMPRESA BRASILEIRA DE AERONÁUTICA S/A & $59,282,223$ & Grande & $\mathrm{SP}$ & $2 \mathrm{Não}$ \\
CRISTÁLIA PRODUTOS QUÍMICOS FARMACÊUTICOS LTDA. & $36,885,251$ & Grande & $\mathrm{SP}$ & $4 \mathrm{Sim}$ \\
VALE SOLUÇÕES EM ENERGIA S.A. - VSE & $30,229,965$ & Micro & $\mathrm{RJ}$ & $1 \mathrm{Não}$ \\
CANAVIALIS S.A & $26,253,604$ & Pequena & $\mathrm{SP}$ & $2 \mathrm{Não}$ \\
ALELLYX S.A & $23,195,014$ & Micro & $\mathrm{SP}$ & $3 \mathrm{Não}$ \\
OPTO ELETRÔNICA S.A. & $22,234,550$ & Média & $\mathrm{SP}$ & $4 \mathrm{Sim}$ \\
AVIBRAS DIVISÃO AÉREA E NAVAL S/A & $18,885,695$ & Pequena & $\mathrm{SP}$ & $1 \mathrm{Sim}$ \\
VICPETRO S.A & $18,542,600$ & Grande & $\mathrm{SP}$ & $1 \mathrm{Sim}$ \\
MECTRON - ENGENHARIA INDÚSTRIA E COMÉRCIO S.A & $13,021,404$ & Média & $\mathrm{SP}$ & $2 \mathrm{Sim}$ \\
GRADIENTE ELETRÔNICA S.A. & $9,720,832$ & Grande & $\mathrm{AM}$ & $1 \mathrm{Não}$ \\
MARCOPOLO S/A & $8,941,744$ & Grande & $\mathrm{RS}$ & $1 \mathrm{Sim}$ \\
IMCOPA IMPORTAÇÃO EXPORTAÇÃO E INDUSTRIA DE ÓLEOS S.A. & $8,011,578$ & Grande & $\mathrm{PR}$ & $1 \mathrm{Sim}$ \\
TECSIS - TECNOLOGIA E SISTEMAS AVANÇADOS LTDA & $7,899,140$ & Grande & $\mathrm{SP}$ & $1 \mathrm{Não}$ \\
MARISA GURJÃO PINHEIRO & $7,856,000$ & Grande & $\mathrm{MG}$ & $1 \mathrm{Não}$ \\
VICUNHA S/A (VICUNHA TÊXTIL) & $7,822,824$ & Micro & $\mathrm{SP}$ & $1 \mathrm{Sim}$ \\
\hline \hline Total geral & $298,782,426$ & & & \\
\hline \hline
\end{tabular}

Chama a atenção que, das quinze empresas, apenas oito concederam entrevista. Entre as justificativas, podemos apontar aquelas ligadas ao fato do projeto ser considerado estratégico, como principal alegação, mas também dificuldades de encontrar os executores dos projetos dentro das empresas. Outro fato relevante é a extrema concentração dessas empresas no Sudeste, sendo dez localizadas em São Paulo e apenas três oriundas de outras regiões brasileiras, uma do Norte e duas do Sul.

Iniciaremos nossas análises pelos comentários das empresas sobre os processos de financiamento à inovação no país. O fato de estar ocorrendo um aumento das possibilidades e condições de financiamento para inovação foi apontado por todas as empresas como uma questão extremamente fundamental para o desenvolvimento e a competitividade nacional. Todas conhecem os outros mecanismos de incentivo à inovação, a maior parte delas utiliza outras formas de financiamentos governamentais e, mais da metade, acessam a 'Lei do Bem'. Porém, as empresas apontaram gargalos no sistema de financiamento, alguns específicos às suas áreas de atuação e outros mais gerais, apresentando sugestões de aperfeiçoamento do sistema. Dentre elas podemos ressaltar: 
- Maior agilidade na liberação dos recursos para o andamento do projeto. Há excesso de burocracia, pouca agilidade no decorrer do processo e de flexibilidade no uso da verba. Um dos representantes sugeriu que a FINEP poderia ter uma forma de analisar a reputação das empresas, para que haja mais agilidade na liberação dos recursos;

- Os projetos têm um formato muito detalhado exigindo relatórios extensos e complexos;

- No caso da saúde, há uma expectativa por reformulação e simplificação dos processos regulatórios na ANVISA para testes pré-clínicos, clínicos e registro de medicamentos, sobretudo nos casos de empresas contempladas com financiamentos do governo (esse apontamento, na verdade, se repete entre os especialistas em políticas de inovação em saúde, como ressaltaremos no próximo capítulo);

- Criação de marco regulatório para parceria público-privada, de maneira que seja possível expandir as garantias jurídicas de proteção intelectual e expertise, dando exclusividade comercial ao parceiro provado, como forma de minimizar riscos e incentivar o desenvolvimento tecnológico nacional;

- Desoneração fiscal sobre a folha de pagamento, pois a inovação depende de profissionais com remuneração elevada, representando uma importante despesa para a empresa;

- Diminuição da carga tributária sobre os valores pagos a prestadores de serviços relacionados às atividades de inovação;

- Tratamento diferenciado na tributação e nos processos aduaneiros para produtos manufaturados em relação aos produtos in natura, beneficiando os primeiros e inibindo a exportação dos segundos;

- As áreas que o Governo deseja incentivar deveriam apenas receber tratamento diferenciado no momento da análise do projeto. Da forma como está hoje, muitas inovações importantes deixam de receber apoio por não se enquadrarem nos editais, embora possam significar grandes benefícios para a sociedade e para a economia brasileira; 
- Contrapartida muito elevada para grandes empresas, o que privilegia mais P\&D do que inovação em si, já que esse aspecto inviabiliza o financiamento para grandes empresas, que efetivamente transformam o P\&D em inovação.

Nestes gargalos apontados, podemos verificar que há uma forte ênfase dada à questão tributária, o que, na verdade, é uma crítica comum entre a classe empresarial brasileira. Por outro lado, a morosidade e o excesso de burocracia se configuram como elementos fundamentais para o entrave ao desenvolvimento dos projetos. Por fim, pelo fato de metade dessas empresas serem grandes, as críticas quanto à contrapartida deveriam ser esperadas, porém, como já ressaltamos no item anterior, a prioridade da FINEP passou a ser o foco na PME.

Do ponto de vista dos projetos, obviamente quase todos são estratégicos para o desenvolvimento nacional, afinal o edital previa sua inserção em temas de interesse pontuados pela FINEP, em consonância com a política industrial. A partir desse momento, realizaremos comentários sobre alguns projetos e seus correlativos desenlaces, que consideramos estruturais na Geopolítica nacional.

Claramente, os projetos ligados à defesa merecem destaque indiscutível. O projeto de desenvolvimento de um Veículo Aéreo Não Tripulado (VANT), pela empresa Avibrás, nos parece ilustrativo da importância do financiamento e está claramente ligado a interesses geopolíticos. Essa empresa foi criada no ano de 1961 e até hoje se mantém integralmente nacional ${ }^{82}$; foi pioneira no setor aeroespacial brasileiro e no setor de sistemas avançados de armas, tendo realizado diversas parcerias com outros países. Um dos principais produtos da empresa é o ASTROS, um Sistema Universal de Foguetes de Artilharia para Saturação de Área, produzido desde 1983. Hoje, o ASTROS II, ainda mais avançado, é utilizado por diversas nações, a exemplo da Malásia, que no ano de 2006 fechou um acordo de compra de 18 exemplares e em 2010 passou a receber a encomenda, segundo Renato Bastos $\operatorname{Tovar}^{83}$. O projeto de

\footnotetext{
${ }^{82}$ Informações disponíveis no sítio:

http://www.avibras.com.br/sys/avibras.asp?AV_LRG=1280\&idioma=1, acesso em 13.03.2011.

${ }^{83}$ Entrevista realizada em 7.04.2010.
} 
VANT, de alta flexibilidade e configuração miltimissão de emprego e reconhecimento, visa complementar funções do ASTROS II e é definido como um dos projetos fundamentais da empresa. Em agosto de 2011, o Ministério da Defesa aprovou o projeto ASTROS 2020, com um financiamento de $R \$ 1$ bilhão, o que ressalta a visão estratégica que a empresa desempenha no país ${ }^{84}$. Não cabe aqui realizar um julgamento de valor dessa ação do governo brasileiro, sobretudo por não termos tido acesso ao projeto.

Finalizando as reflexões sobre a questão estratégica dos desembolsos uma reflexão se faz necessária: o direcionamento da subvenção a empresas brasileiras.

Os editais da Subvenção Econômica são aparados legalmente na Lei 10.973/2004, regulamentada pelo Decreto 5.563/2005, que prevê, no parágrafo $3^{\circ}$ do seu Capítulo IV: "Os recursos destinados à subvenção econômica serão aplicados no custeio de atividades de pesquisa, desenvolvimento tecnológico e inovação em empresas nacionais". Em primeiro lugar é importante ressaltar que não foram destinados recursos a empresas estrangeiras em nenhum de seus editais, porém duas empresas contratadas pela FINEP foram adquiridas por uma gigante multinacional que opera no país, são elas: Alellyx Applied Genomics e Canaviallis, empresas que, no momento em que foram beneficiadas com o financiamento, estavam ligadas ao Grupo Votorantim, mais especificamente, controladas pela Votorantim Ventures Capital (VVenture).

\begin{tabular}{|c|c|c|c|c|}
\hline & 2006 & 2007 & 2008 & Total \\
\hline ALELLYX S.A & $8.733 .685,99$ & $9.451 .328,39$ & $5.010 .000,00$ & $23.195 .014,38$ \\
\hline CANAVIALIS S.A & $6.345 .804,18$ & & $19.907 .800,00$ & $26.253 .604,18$ \\
\hline Total Grupo Votorantim & $15.079 .490,17$ & $9.451 .328,39$ & $24.917 .800,00$ & 49.448.618,56 \\
\hline
\end{tabular}

Explicita-se aqui o nome das empresas, pois o caso se tornou público e as informações descritas a seguir foram compiladas do jornal Valor

\footnotetext{
${ }^{84}$ Notícia do Jornal $O$ Vale, publicada em 2 de agosto de 2011, "Indústria prevê que recursos sejam disponibilizados até o final do ano; 170 podem ser recontratados".
} 
Econômico $^{85}$. Em relação aos números, a primeira foi contemplada com o financiamento nos anos de 2006, 2007 e 2008, tendo um valor total de contratos da ordem de $\mathrm{R} \$ 2$ 23.195.014,38 para projetos ligados ao desenvolvimento biotecnológico da cana-de-açúcar e do eucalipto. Já a segunda participou apenas nos anos de 2006 e 2008, porém com cifras ainda superiores, da ordem de $\mathrm{R} \$ 26.253 .604,56$, também em projetos ligados à cana-de-açúcar. As cifras correspondem, respectivamente, ao quinto e ao quarto maior financiamento particular da Subvenção, sendo que as duas empresas, em conjunto, teriam angariado o segundo maior financiamento, inferior apenas a uma grande empresa do setor aeroespacial. É praticamente dispensável o comentário sobre a importância do desenvolvimento biotecnológico em relação às culturas a que a empresa se dedica, sobretudo a cana, tendo em vista nosso volume de produção e nossa matriz energética, porém é fundamental comentar sobre a aquisição dessas duas empresas pela multinacional Monsanto, em 2008.

A trajetória histórica das duas empresas em questão nos remonta ao ano de 2000, com a criação do fundo Votorantim Venture, focado em investimentos nas áreas de Tecnologia da Informação, Telecomunicações e Biotecnologia. A Alellyx foi a primeira empresa de risco do fundo; criada através da associação de cinco cientistas do projeto Genoma, em 2002, a empresa tem linhas de pesquisa ligadas ao sequenciamento dos genomas de bactérias causadoras de doenças em plantas e análise dos genomas da cana-de-açúcar e do eucalipto, duas culturas economicamente importantes para o país. O valor inicial do projeto gerido pelo fundo era de $R \$ 30$ milhões, que seriam utilizados para construção de laboratórios e desenvolvimento das primeiras pesquisas. O laboratório foi inaugurado em novembro de 2002, com projetos para cana-deaçúcar, eucalipto e laranja, mas já com previsões de expansão para as culturas de soja e uva, sendo todos eles voltados à criação de produtos para a solução de problemas na produção dessas culturas. A questão da exploração de patentes era vista como central para a empresa, fato que se concretizou, a

\footnotetext{
${ }^{85}$ Devido ao fato das informações terem sido compiladas no jornal Valor Econômico e mais de uma fonte ter servido de referência em algumas partes da análise, o texto mostrou-se confuso. Assim, optou-se pela não referência das matérias direta no texto.
} 
exemplo do sequenciamento do método de desenvolvimento de plantas transgênicas resistentes ao vírus da leprose, entre outros.

A outra empresa do grupo, a Cannvialis, foi criada em março de 2003 com investimentos previstos da ordem de $\mathrm{R} \$ 25$ milhões. Na sua concepção, a empresa estaria voltada às atividades ligadas à biotecnologia, neste caso particular, dedicadas ao melhoramento de variedades de cana-de-açúcar por meio da genética molecular. O modelo de associação com pesquisadores acadêmicos foi mantido, desta vez com a presença de cinco renomados cientistas oriundos da Universidade Federal de São Carlos. A proposta inicial contava com a criação de três estações experimentais, uma biofábrica, um laboratório de biologia molecular e outro de fitopatologia. Entre os objetivos da empresa merecia destaque a venda, às usinas de cana-de-açúcar, de pacotes tecnológicos completos, incluindo consultoria com vistas à otimização do uso das melhores variedades por região. Já em 2006, a empresa era responsável pela genética de $10 \%$ das variedades de cana produzidas no Brasil, além de produzir, em Conchal (SP), um tipo de variedade que rende mais de $70 \%$ de sacarose por hectare. Sua expansão também foi considerável, de 2006 a 2007 a área atendida pela empresa passou de 120 mil hectares para $940 \mathrm{mil}$, segundo o presidente à época, Ricardo Madureira. A busca por novas variedades fez com que a empresa expandisse também seus polos de pesquisa, que hoje são sete, espalhados pelo Brasil $^{86}$.

Dada essa pequena apresentação do desenvolvimento dessas duas empresas, não faltam motivos que justifiquem a liberação de recursos não reembolsáveis por parte da FINEP, fato que efetivamente se deu em cinco projetos. Afinal, eram empresas de biotecnologia, considerada área estratégica em todos os editais, e estavam lidando com o desenvolvimento de tecnologias fundamentais; vide a cana, que, além da sacarose, é uma fonte de energia renovável em um período histórico marcado pela crescente busca por fontes alternativas de energia. Tanto a Alellyx, quanto a CanaVialis não só tiveram sucesso em seus projetos, como também desenvolveram várias parcerias tanto com ICTs brasileiros, quanto com a própria Monsanto. E aqui se inicia a

${ }^{86}$ Pólos Regionais de Tecnologia: São Paulo - Centro; São Paulo - Oeste; Minas Gerais; Paraná; Tocantins; Maranhão; e Nordeste. 
contextualização da compra das duas empresas. Em maio de 2007, foi assinado um acordo entre a Alellyx, a CanaVialis e a Monsanto, para o desenvolvimento de variedades de culturas convencionais e transgênicas. $O$ acordo previa compartilhamento de banco de germoplasmas, além do desenvolvimento de sementes transgênicas de milho, soja, algodão e canola tolerantes à seca. No caso da Alellyx, o acordo significava sua entrada no mercado internacional, enquanto para a CanaVialis, que já havia exportado variedades para Angola, sua expansão. Segundo o jornal Valor Econômico (05/03/2007), nessa mesma época o presidente da CanaVialis havia anunciado, sem mencionar nome de empresas, que tinha sido procurado por investidores estrangeiros, o que não causa espanto, já que a empresa é, até hoje, a líder mundial em pesquisas com cana.

O fato é que no final de 2008 foi anunciada a aquisição da Alellyx e da CanaVialis, pela Monsanto. Esta empresa, que já liderava pesquisas com soja, milho e algodão, estendeu suas atribuições à cana também. Quanto à estratégia dessa gigante mundial, não há o que ponderar, ou melhor, não é interesse da presente análise. Porém, essas empresas foram contempladas com quase $\mathrm{R} \$ 50$ milhões apenas da FINEP, tendo ainda recebido empréstimos do BNDES no valor de aproximadamente R\$39 milhões, com juros conhecidamente mais módicos no Brasil, cerca de $4,5 \%$ ao ano, situação deveras favorável, em se tratando de financiamentos públicos. A questão normativa volta a ter destaque. Ou seja, não há como negar que houve uma lacuna legal que permitiu a aquisição dessas empresas por uma multinacional, o que por sua vez distorce os objetivos centrais deste modelo de financiamento à inovação pautado no desenvolvimento da inovação tecnológica em empresas brasileiras. Esse assunto será devidamente retomado nas conclusões desta tese. 


\section{CAPÍTULO 4 - Políticas Federais para Ciência, Tecnologia e Inovação em Saúde no Brasil: a Saúde como Área Estratégica para a Geopolítica Nacional ${ }^{87}$}

No capítulo primeiro, procuramos estabelecer os nexos teóricos ligados ao sistema nacional de inovação. Ressaltamos, na ocasião, que a saúde recebe destaque privilegiado por se tratar de uma área que contempla política social e econômica. Albuquerque, Souza e Baessa (2004:278) chamam atenção para o fato de que, além dos impactos econômicos diretos gerados pelas atividades inovadoras, o caso da saúde, em particular, tem impacto direto na qualidade de vida da população, o que, por sua vez, tem repercussões na capacidade inovativa do país. E nessa relação de via dupla transparece um elemento fundamental da geopolítica brasileira, afinal estamos falando não só da vida dos cidadãos brasileiros, como da sustentação de atividades econômicas que têm suas bases tecnológicas dominadas por grandes conglomerados internacionais.

A história das cadeias produtivas ligadas à saúde, no Brasil, revela uma complexidade dada pela criação de institutos públicos de pesquisa, como o Butantan e a FIOCRUZ, fundamentais à produção de vacinas e reagentes para diagnósticos, convivendo com empresas multinacionais, laboratórios nacionais e a crescente importação de produtos, sobretudo nos últimos anos, como resultado do crescimento econômico brasileiro aliado à valorização do real. $\mathrm{Ou}$ seja, esses fatores demonstram uma vasta gama de abordagens possíveis sobre o tema.

\footnotetext{
${ }^{87}$ Todas as entrevistas utilizadas para as análises deste capítulo foram realizadas para o projeto: "Tecnologia Diagnóstica para Doenças Crônico-Degenerativas: Estudo sobre o Modelo de Incorporação do Primeiro Aparelho de PEC-CT no Brasil - (2008/2010)". Instituição Financiadora: MCT/CNPq/ANS $N^{\circ}$ 25/2007. Departamento de Medicina Preventiva da Faculdade de Medicina da Universidade de São Paulo (DP/FM/USP). Coordenação: Profa. Dra. Ana Luiza D'Ávila Viana. Agradecemos a Coordenadora do projeto que, devido à pertinência dos conteúdos das entrevistas em relação à temática da tese, nos cedeu o direito de utilizar essas informações.
} 
Essa complexidade não será o foco central de nossa análise. O que pretendemos demonstrar é a crescente participação da saúde nos programas e financiamentos à inovação, nos últimos anos, como aspecto central de uma tentativa de diminuição da dependência externa nesse setor. É importante frisar tal aspecto, já que não realizaremos análises específicas, por exemplo, dos maiores ICTs em saúde, Butantan e FIOCRUZ. Sabemos que ambos são os principais produtores nacionais de vacinas e que esse mercado, inteiramente público, constitui um elemento estratégico das políticas de inovação em saúde; afinal, as compras são feitas majoritariamente pelo setor público e qualquer alteração de custos, como no caso da inserção de produtos importados, o preço será pago pelos cofres públicos (IBANEZ, WEN e FERNANDES, 2007:15). Porém, nossa abordagem, como já mencionado, dar-se-á pelas políticas de incentivo à inovação e seus desdobramentos.

Assim, este capítulo foi concebido para dar destaque à extrema relevância geopolítica das políticas de inovação em saúde, assim como ao fato dessas políticas terem tido uma forte institucionalização em diferentes órgãos públicos, com financiamentos específicos e definição de tecnologias a serem contempladas, diante das necessidades nacionais.

Na PITCE de 2003, já passamos a verificar o fortalecimento do sistema nacional de inovação em saúde, com a introdução de cadeias produtivas diretamente ligadas à saúde, como a de fármacos e medicamentos. Para dar sustentação a essa política foi criada a linha de crédito Profarma, no BNDES, e, como mencionamos no capítulo anterior, a Subvenção Econômica da FINEP, que, em todos os anos, teve a saúde como uma das áreas estratégicas.

Podemos citar também outras iniciativas que são direta ou indiretamente ligadas à inovação e que apresentam pontos específicos ligados à saúde. Entre elas destacamos: o 'PAC Saúde - Mais Saúde: direito de todos', programa lançado em 2007 pelo Ministério da Saúde; o ‘PACT\&Inovação - Plano de Ação em Ciência, Tecnologia e Inovação 2007-2010', do Ministério da Ciência e Tecnologia; a 'Política de Desenvolvimento Produtivo', do Ministério do Desenvolvimento, Indústria e Comércio Exterior (MDIC), que conta como apoio de uma Secretaria-Executiva, formada pela Agência Brasileira de 
Desenvolvimento Industrial (ABDI), BNDES e Ministério da Fazenda, e o 'Estudo da Dimensão Territorial do Planejamento', capitaneado pelo Ministério do Planejamento, Orçamento e Gestão, através da Secretaria Executiva e Secretaria de Planejamento e Investimentos Estratégicos, em parceria com o Centro de Gestão e Estudos Estratégicos (CGEE). Porém, aqui daremos ênfase a duas em especial: 'Mais Saúde' e sua relação com a PITCE e o PACT\&I.

Em primeira instância, abordamos a PITCE e a cadeia produtiva de fármacos, objetivando pontuar alguns aspectos dessas novas políticas. Depois pontuamos as principais preocupações, proposições e linhas específicas à saúde em cada uma das políticas voltadas à inovação no país.

No final, analisamos a atual situação brasileira em relação à balança comercial, com ênfase na saúde, salientando a necessidade de manutenção dessas políticas. Pelo fato das atividades produtivas ligadas à saúde estarem fortemente concentradas em São Paulo, finalizamos com uma análise da política estadual de parques tecnológicos baseados na área da saúde.

\subsection{A Política Industrial Tecnológica e de Comércio Exterior e a indústria farmacêutica}

$\mathrm{Na} \mathrm{CNCTI}{ }^{88}$, de 2001, foram discutidos os cinco temas centrais julgados essenciais ao desenvolvimento de uma estrutura nacional de inovação: o avanço do conhecimento; a qualidade de vida; o desenvolvimento econômico; os desafios estratégicos; e os desafios institucionais. Desde então, houve um relativo avanço nessa discussão, sem, é claro, em função do curto espaço de tempo, ter tido uma mudança radical nas práticas inovadoras de instituições e empresas brasileiras.

\footnotetext{
${ }^{88}$ Ver Gonçalves e Melo (2001).
} 
Por outro lado, no final do ano de 2003, o Governo Federal lançou a PITCE, que, segundo Arbix (2007), foi a "ponte entre as políticas públicas e o mundo empresarial, colocando no centro das preocupações governamentais a busca de alterações de qualidade em nosso sistema produtivo". A PITCE teve como diretriz fundamental "o aumento da eficiência econômica e do desenvolvimento e difusão de tecnologias com maior potencial de indução do nível de atividade e de competição no comércio internacional" (BRASIL, 2003). Para que esses objetivos fossem alcançados foram selecionados setores estratégicos, que deveriam receber maiores aportes de incentivos. São eles: semicondutores; software; fármacos e medicamentos e bens de capital ${ }^{89}$.

É importante ressaltar que essa política foi idealizada por um espectro grande de instituições: Casa Civil da Presidência da República; MDIC; Ministério da Fazenda (MF); Ministério do Planejamento, Orçamento e Gestão (MPOG); MCT; IPEA; BNDES; FINEP; Agencia de Promoção das Exportações (APEX Brasil). Dentre elas, o MDIC era o maior responsável pela aplicação e o BNDES criou várias formas de financiamento para inovação, incluindo o Profarma, que visava aumentar a capacidade inovadora da indústria farmacêutica e estava em operação até o término desta tese. Vale destacar que cada vez mais o MCT passou a trabalhar como colaborador na execução da PITCE, visando dar mais escopo à integração das políticas industrial e tecnológica. Por fim, o IPEA, a FINEP e o próprio BNDES promoveram estudos e seminários vinculados ao tema da inovação, sempre relacionado às questões do desenvolvimento, tendo a FINEP ainda o papel de executar os financiamentos dos Fundos Setoriais, que contemplam a saúde através do CTSaúde, e a Subvenção Econômica, que também financia diretamente o setor.

No caso da indústria farmacêutica, seu desenvolvimento no Brasil revela um histórico complexo que nos remonta ao século XIX. Bicudo Jr. (2009) realizou uma periodização desse processo no território brasileiro, dividida em quatro momentos: técnico (1850-1949); científico (1950-1975); informacional

${ }^{89}$ Segundo o documento "Balanço da PITCE-2005", divulgado pela Agência Brasileira de Desenvolvimento Industrial (ABDI), o setor que mais cresceu no período foi o de bens de capital. Disponível no site http://www2.desenvolvimento.gov.br/sitio/ascom/ascom/polindteccomexterior.php, acesso em 15.05.2009. 
(1976-1996) e normativo (1997-...). O primeiro remonta ao final do século XIX e início do XX, em que a produção nacional ficou dividida em um grupo caracterizado por pequenos laboratórios de remédios tradicionais e outro de grandes produtores nacionais e estrangeiros, operando em escalas maiores, ambos sem conteúdos científicos. Em um segundo momento, a produção foi alterada pela introdução da química sintética. Essa indústria passou a ser um dos símbolos do novo tempo industrial. O mercado nacional foi afetado drasticamente não apenas pela capacidade de escala de empresas estrangeiras, mas também por suas inovações, tornando obsoletos medicamentos de base natural. Bicudo Jr. (idem:162) aponta que, a partir de 1964, dois fatores impulsionam as empresas estrangeiras: a falta de política de preços e a extinção da fiscalização de importação de matéria-prima. A produção no Brasil passa a ser realizada majoritariamente por grandes grupos estrangeiros, fazendo com que a importação de medicamentos fosse de apenas $2 \%$, patamar mantido até a década de 1980 .

Pelo domínio dos novos serviços e dos recursos informacionais, as multinacionais passam a ter caráter hegemônico, configurando o período informacional. Agora, a ciência perde relativo valor, dando lugar a ações baseadas em novas formas organizacionais e tendo a integração com programas de computador como motor das inovações. Neste momento, o governo brasileiro começa a enxergar a necessidade de fortalecer o sistema de inovação para a produção de medicamentos por empresas brasileiras (op. Cit::169). A Companhia de Desenvolvimento Tecnológico (Codetec), criada em uma associação entre capital privado, recursos estatais e a Universidade Estadual de Campinas (Unicamp), é dada como exemplo. Porém, as pressões de grupos estrangeiros junto ao Estado, a dificuldade da empresa ter acesso amplo ao território nacional e a estratégia de cópias de moléculas em detrimento de técnicas inovadoras diminuíram a força dessa iniciativa. Assim, no final da década de 1990, o Brasil contava com 350 laboratórios farmacêuticos e os multinacionais, apenas 56 , controlavam $72 \%$ do mercado (PERREIRA, 2002, apud Bicudo Jr., op. Cit.:171). 
Bicudo Jr. (op. Cit:173) pontua o último período, normativo, como aquele em que a "criação da nova agência de vigilância sanitária, a edição da lei dos medicamentos genéricos e a formação de um poderoso grupo de laboratórios nacionais são alguns eventos internos que alteram as lógicas" da produção farmacêutica. Do ponto de vista da produção, as estratégias das empresas estrangeiras mantiveram-se as mesmas do último período, ou seja, concentram a produção em poucas unidades especializadas que servem de bases globais de exportação. Mas as atividades de P\&D continuaram sendo realizadas fora do país.

Deve ficar claro, portanto, que o Brasil continua ainda com pouca capacidade inovativa nessa cadeia produtiva de fármacos e medicamentos, realizando no território nacional basicamente atividades como embalagem. Esse fato vem fazendo com que o governo federal promova políticas para a sua transformação. Ou seja, pudemos observar mudanças em relação às políticas de inovação, principalmente através da maior participação do Estado nas políticas industriais em saúde. É claro que a discussão do papel do Estado como indutor não se apresenta como consenso, havendo várias críticas, tanto positivas, quanto negativas, como veremos a seguir.

A Federação Brasileira da Indústria Farmacêutica (FEBRAFARMA) realizou, no ano de 2007 , um estudo ${ }^{90}$ sobre os impactos da PITCE nessa cadeia produtiva. Esse trabalho apresenta um quadro sobre os padrões de políticas industriais (ver Quadro 1).

${ }^{90}$ Barbosa, Mendes e Sennes (2007). 


\section{Quadro 1 - Os Padrões de Política Industrial de acordo com algumas características}

\begin{tabular}{|c|c|c|c|}
\hline & Padrão Liberal & Padrão Estruturalista & $\begin{array}{c}\text { Padrão neo- } \\
\text { schumpeteriano }\end{array}$ \\
\hline Concepção teórica & $\begin{array}{l}\text { Mercados em concorrência } \\
\text { perfeita e predomínio das } \\
\text { vantagens comparativas }\end{array}$ & $\begin{array}{l}\text { Mercados oligopolizados } \\
\text { e estrutura do comércio } \\
\text { internacional hierárquica }\end{array}$ & $\begin{array}{c}\text { Descarta o conceito de } \\
\text { equilíbrio, mas não lida } \\
\text { com } \\
\text { a noção de setores; foco } \\
\text { na } \\
\text { inovação e no aprendizado } \\
\text { das empresas em } \\
\text { estruturas } \\
\text { de mercado específicas }\end{array}$ \\
\hline Papel do Estado & $\begin{array}{c}\text { Apenas admitido em } \\
\text { situações de "falha de } \\
\text { mercado" }\end{array}$ & $\begin{array}{c}\text { Defesa do conceito de } \\
\text { indústria nascente, } \\
\text { possuindo } \\
\text { o Estado papel importante } \\
\text { na soberania econômica } \\
\text { da } \\
\text { nação }\end{array}$ & $\begin{array}{c}\text { Criação de novas } \\
\text { externalidades, } \\
\text { inexistentes } \\
\text { por ausência de } \\
\text { informação } \\
\text { ou por limitada } \\
\text { coordenação } \\
\text { dos investimentos entre } \\
\text { os agentes de uma cadeia } \\
\text { produtiva } \\
\end{array}$ \\
\hline $\begin{array}{l}\text { Papel das empresas } \\
\text { de } \\
\text { capital estrangeiro }\end{array}$ & $\begin{array}{c}\text { Fundamentais, pois } \\
\text { incorporam progresso } \\
\text { técnico }\end{array}$ & $\begin{array}{c}\text { Fundamentais, desde } \\
\text { que acompanhem as } \\
\text { determinações gerais } \\
\text { da política econômica e } \\
\text { industrial }\end{array}$ & $\begin{array}{c}\text { Fundamentais, se trazem } \\
\text { para o País os seus } \\
\text { centros de } \\
\text { P\&D e não inibem o } \\
\text { sistema } \\
\text { nacional de inovação }\end{array}$ \\
\hline $\begin{array}{l}\text { Funcionalidade das } \\
\text { políticas setoriais }\end{array}$ & $\begin{array}{l}\text { Distorcem o mercado, } \\
\text { ocasionam desperdício de } \\
\text { recursos públicos e } \\
\text { 'quaserenda' } \\
\text { para os empresários } \\
\text { favorecidos }\end{array}$ & $\begin{array}{c}\text { São vitais para a } \\
\text { diversificação industrial e } \\
\text { para uma inserção externa } \\
\text { mais qualificada (existem } \\
\text { setores de ponta e setores } \\
\text { de } \\
\text { commodities) }\end{array}$ & $\begin{array}{c}\text { Apenas relativa, já que o } \\
\text { foco } \\
\text { da ação governamental } \\
\text { deve } \\
\text { ser a empresa. Mesmo } \\
\text { assim, } \\
\text { as ações sistêmicas } \\
\text { acabam } \\
\text { por ter impactos setoriais } \\
\text { diferenciados }\end{array}$ \\
\hline Preocupação central & $\begin{array}{c}\text { Ênfase na competitividade } \\
\text { sistêmica do País num } \\
\text { regime } \\
\text { aberto às importações e } \\
\text { aos } \\
\text { investimentos }\end{array}$ & $\begin{array}{c}\text { Ênfase setorial, } \\
\text { promovendo o } \\
\text { upgrading do País em } \\
\text { alguns } \\
\text { setores estratégicos, } \\
\text { reduzido } \\
\text { assim a vulnerabilidade } \\
\text { externa }\end{array}$ & $\begin{array}{l}\text { Ênfase no processo de } \\
\text { aprendizado entre o setor } \\
\text { público e privado que } \\
\text { potencialize a constante } \\
\text { inovação tecnológica }\end{array}$ \\
\hline $\begin{array}{l}\text { Políticas mais } \\
\text { recomendadas }\end{array}$ & $\begin{array}{c}\text { Baixa dispersão das } \\
\text { tarifas, } \\
\text { maior eficiência na } \\
\text { infraestrutura, } \\
\text { redução do custo } \\
\text { trabalhista, investimento } \\
\text { em capital humano, } \\
\text { fortalecimento das } \\
\text { agências } \\
\text { antitruste e admissão de } \\
\text { políticas creditícia e de } \\
\text { auxílio } \\
\text { à inovação para empresas } \\
\text { (jamais para setores) }\end{array}$ & $\begin{array}{c}\text { Deve haver espaço para } \\
\text { elevação temporária de } \\
\text { tarifas, incentivos setoriais, } \\
\text { manutenção de critérios de } \\
\text { similaridade e de índices } \\
\text { de } \\
\text { nacionalização, defesa das } \\
\text { câmaras setoriais e do } \\
\text { poder } \\
\text { de compra do Estado no } \\
\text { apoio } \\
\text { de setores estratégicos }\end{array}$ & $\begin{array}{c}\text { Aceita instrumentos das } \\
\text { políticas tanto horizontais } \\
\text { como verticais. O destaque } \\
\text { está para a construção da } \\
\text { política industrial enquanto } \\
\text { espaço institucional de } \\
\text { interação entre os setores } \\
\text { público e privado }\end{array}$ \\
\hline
\end{tabular}

Fonte: Febrafarma (2007) com base em Franco (1999), Gadelha (2001), Rodrik (2004), Suzigan (1997), Suzigan e Furtado (2006).

Elaboração: Prospectiva

Segundo a visão da própria Febrafarma, uma política industrial deve estar entre os padrões estruturalistas e neo-schumpeterianos. Para a indústria 
farmacêutica, o estudo afirma ser necessária a intervenção do Estado, desde que com algumas ressalvas. Gadelha (2006) parece concordar quando aponta que o recorte para tratar a questão das atividades econômicas ligadas à saúde deve ser estruturalista, marxista e schumpeteriano. Esse autor ressalta, ainda, a extrema complexidade que envolve questões ligadas à saúde. A consolidação do SUS e de suas bases sanitaristas criaram uma verdadeira vertente crítica muito pautada na ampliação exacerbada do papel do Estado na constituição de um sistema equânime e universal, porém, desconsiderando a atuação do Estado nas políticas de desenvolvimento nacional em bases empresariais (idem:15). Fato que entrava uma discussão mais ampla em direção às políticas diretamente ligadas ao setor empresarial privado nacional.

Segundo Barbosa, Mendes e Sennes (2007:21), quando

se empreende qualquer ação de política industrial voltada ao setor farmacêutico, um conjunto de ao menos quatro fatores deve ser levado em consideração: complexidade do setor, formas de intervenção do Estado (especialmente controle de preços, marco regulatório e carga tributária), Lei de Patentes e legislação sobre os genéricos. Do contrário, corre-se o risco de que se manifestem efeitos diversos daqueles antevistos quando da formulação da política.

E é sobre essa perspectiva que a Febrafarma realizou o estudo, apontando limites e impactos da PITCE. Os principais resultados apresentaremos a seguir.

A cadeia produtiva do setor farmacêutico tem algumas particularidades que merecem ressalvas. Em primeiro lugar, o faturamento do setor, em 2005, ficou dividido em $60 \%$ para empresas de capital estrangeiro e $40 \%$ para as de capital nacional, fato que explicita a dependência externa do Brasil em relação ao setor. Em segundo, nesse setor, apesar de ter sido o quarto em termos de taxa de inovação, segundo a PINTEC (2003), as empresas de capital estrangeiro concentram suas atividades, sobretudo, na produção de medicamentos e introdução no mercado (estágios 3 e 4 da cadeia 
farmacêutica), enquanto as atividades de P\&D de princípios ativos e produção em escala (estágios 1 e 2) ficam concentradas em seus países de origem. Isso reduz, em muito, a possibilidade da inovação ser praticada dentro do país, algo que levaria à diminuição da dependência externa.

Outro fator que contribui para esse processo está ligado ao fato das empresas de capital estrangeiro apresentarem elevados déficits comerciais. Houve uma tendência de aumento do déficit comercial da indústria farmacêutica, na década de 1990, que foi reflexo, por um lado, do movimento de fusões e aquisições que resultou no fechamento e na concentração de plantas produtoras de farmoquímicos e, por outro, de uma mudança estrutural do coeficiente de abertura dessa indústria (CAPANEMA E PALMEIRA, 2004). Esse fato gerou um verdadeiro "enxugamento da cadeia produtiva do setor, transformando o país num produtor e exportador marginal, fundamentalmente de produtos farmacêuticos nos segmentos e etapas de baixo valor agregado" (BARBOSA, MENDES E SENNES, 2007:39).

Sob esse ponto de vista, o governo brasileiro, além da PITCE, também tem estimulado os laboratórios públicos propondo a criação de uma Superfarma. Esse movimento não é visto com 'bons olhos' pela Febrafarma, que, aliás, é exatamente uma das maiores críticas da política para o setor. Essa questão das críticas, ainda, se relaciona diretamente com as compras governamentais. Na visão da Febrafarma, tal política privilegia os laboratórios públicos e pode gerar um aumento ainda maior da capacidade ociosa dos laboratórios privados.

Entre as políticas do governo que são criticadas pelo estudo, podemos elencar: o controle de preços; o marco regulatório; a regulamentação dos farmoquímicos; o Conselho de Gestão do Patrimônio Genético; o CONEP e a ANVISA na liberação de pesquisas clínicas; os próprios procedimentos da ANVISA; a Lei de Genéricos e a propriedade intelectual. As que merecem destaque, em relação à inovação, dizem respeito à regulação e à morosidade das agências governamentais, principalmente a ANVISA. 
Entre outros aspectos, a Febrafarma também acredita que o sistema de saúde deve ter uma articulação estreita com o sistema de ciência, tecnologia e inovação visando originar um verdadeiro sistema nacional de ciência, tecnologia e inovação em saúde.

O desempenho recente do setor foi analisado em dois principais textos: Barbosa, Mendes e Sennes, 2007; e Capanema, Palmeira e Pieroni, 2008. Alguns dados não refletem, ainda, melhoras significativas, mas os orçamentos em C\&T na saúde aumentaram de maneira significativa, como podemos observar no Gráfico 6 e no valor dos desembolsos da Subvenção Econômica, de 2006 até $2009^{91}$. Vale ressaltar, entretanto, que ainda há uma expressiva diferença entre o orçamento em si e sua efetiva execução. Ou seja, enquanto o orçamento foi elevado nesse período, sua execução acabou ficando muito aquém do total disponibilizado, fato que revela dificuldades em acessar esses recursos. Isso se dá principalmente pela política de geração de elevados superávits primários, com contingenciamento de recursos (BARBOSA, MENDES E SENNES, 2007).

\section{Gráfico 6 - Recursos do CT-Saúde (2003-2006) (\%) - Orçamento e Execução}

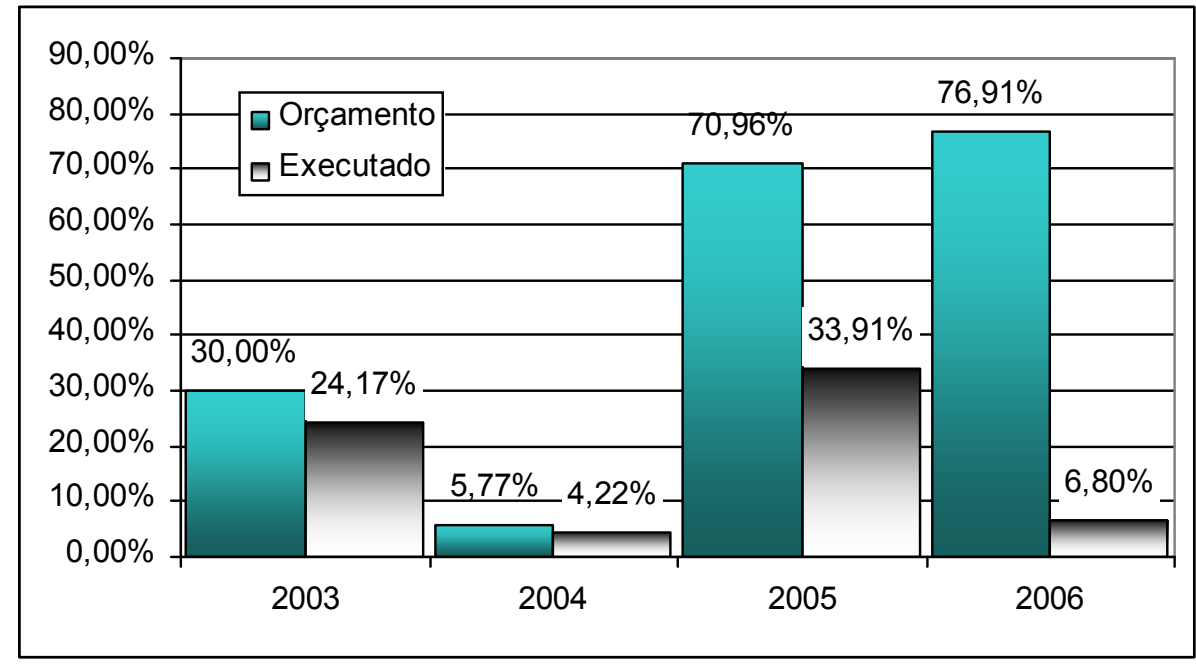

Fonte: Barbosa, Mendes e Sennes, 2007

\footnotetext{
91 Nesse período, os desembolsos da FINEP exclusivos para a saúde foram de aproximadamente $\mathrm{R} \$ 204,4$ milhões.
} 
Não menos importantes para o setor foram, também, os incentivos fiscais concedidos pela 'Lei do Bem'. Segundo dados publicados pelo Ministério da Ciência e Tecnologia, em seu Relatório Anual de Utilização de Incentivos Fiscais de 2008, o setor farmacêutico foi o sexto que mais recebeu incentivos, fato que, ainda assim, não se configura como fundamental para a diminuição do déficit fiscal do setor, nos últimos anos (ver Tabela 12).

\begin{tabular}{lc}
$\begin{array}{l}\text { Tabela } \mathbf{1 2} \text { - Benefícios Reais dos Investimentos } \\
\text { de P\&D por Setor, 2007 }\end{array}$ \\
\hline Setores & $\begin{array}{c}\text { Total dos Benefícios Reais } \\
\text { xR } \$ 1.000,00\end{array}$ \\
\hline Agroindústria & $10.968,13$ \\
Alimentos & $7.698,75$ \\
Bens de Consumo & $51.880,48$ \\
Construção Civil & $4.548,02$ \\
Eletroeletrônica & $41.197,03$ \\
Farmacêutica & $34.794,55$ \\
Mecânica e & \\
Transportes & $339.381,53$ \\
Metalurgia & $41.953,15$ \\
Mineração & 147,74 \\
Moveleira & $3.359,21$ \\
Outras Indústrias & $30.968,60$ \\
Papel e Celulose & $10.290,72$ \\
Petroquímica & $262.057,78$ \\
Química & $9.192,48$ \\
Software & $8.025,66$ \\
Telecomunicação & $9.097,89$ \\
Textil & $2.893,52$ \\
\hline Totais & $868.455,24$ \\
\hline Fonte: Brasil, 2008 &
\end{tabular}

Já do ponto do ponto de vista da relação do setor com o comércio exterior, algumas observações devem ser feitas. Em 2005, o Brasil figurava em $20^{a}$ posição, no ranking dos maiores exportadores de produtos farmacêuticos. Porém, se observarmos a Tabela 13 e a Tabela 14, veremos que os déficits comerciais para os setores de medicamentos e farmoquímicos ainda são elevados. Juntam-se a esses setores o de equipamentos e materiais hospitalares e odontológicos, Tabela 15. 


\begin{tabular}{cccc}
\multicolumn{4}{c}{ Tabela 13 - Balança Comercial de Medicamentos (Em } \\
US\$ Milhões) \\
\hline Ano & Exportações & Importações & Saldo Comercial \\
\hline 2000 & 218,7 & $1.421,20$ & $-1.202,50$ \\
2001 & 241,7 & $1.522,10$ & $-1.280,40$ \\
2002 & 253,5 & $1.527,80$ & $-1.274,30$ \\
2003 & 279,9 & $1.512,20$ & $-1.232,30$ \\
2004 & 351,2 & $1.784,80$ & $-1.433,60$ \\
2005 & 473,3 & $2.037,20$ & $-1.563,90$ \\
2006 & 622,1 & $2.609,50$ & $-1.987,30$ \\
2007 & 745,6 & $3.521,50$ & $-2.775,90$ \\
\hline
\end{tabular}

Fonte: Capanema, Palmeira e Pieroni, 2008

Tabela 14 - Balança Comercial de Farmoquímicos (Em US\$ Milhões)

\begin{tabular}{cccc}
\hline Ano & Exportações & Importações & Saldo Comercial \\
\hline 2001 & 116,6 & 908,8 & $-792,3$ \\
2002 & 127,0 & 831,6 & $-704,6$ \\
2003 & 133,1 & 851,8 & $-718,7$ \\
2004 & 196,2 & $1.042,7$ & $-846,5$ \\
2005 & 211,3 & $1.091,7$ & $-880,4$ \\
2006 & 221,6 & $1.114,4$ & $-892,8$ \\
2007 & 272,6 & $1.600,0$ & $-1.327,4$ \\
\hline
\end{tabular}

Fonte: Capanema, Palmeira e Pieroni, 2008

Tabela 15 - Balança Comercial de Equipamentos, Aparelhos e Materiais Médicos, Hopitalares e Odontológicos (Em US\$ Milhões)

\begin{tabular}{cccc}
\hline Ano & Exportações & Importações & Saldo Comercial \\
\hline 2001 & 187,5 & $1.093,9$ & $-906,3$ \\
2002 & 195,3 & 948,9 & $-753,7$ \\
2003 & 222,7 & 851,5 & $-628,9$ \\
2004 & 317,9 & 979,8 & $-661,9$ \\
2005 & 398,4 & $1.276,1$ & $-877,7$ \\
2006 & 441,8 & $1.590,8$ & $-1.149,0$ \\
\hline
\end{tabular}

Fonte: Capanema, Palmeira e Pieroni, 2008 
A década de 1990 foi marcada "pelo incentivo às importações via redução das tarifas aos produtos estrangeiros, como parte das políticas de abertura comercial e pela forte apreciação do câmbio a partir do Plano Real", a isso se somam as fusões e aquisições de multinacionais, que diminuíram a integração da capacidade produtiva nacional (CAPANEMA, PALMEIRA E PIERONI, 2008). Porém, chama atenção o fato de, nos últimos anos, esse comportamento ter se acirrado ainda mais, mesmo com a PITCE e o Profarma. "A constatação é relevante pelo caráter estratégico desse complexo produtivo para o país, proveniente de seus impactos diretos na saúde e no bem-estar da população brasileira, além de sua incontestável contribuição para a geração e a difusão do conhecimento científico e tecnológico" (idem:16).

Após esses estudos, os números ainda não se alteraram, segundo os dados da Secretaria de Comércio Exterior do MDIC. Essa apreciação será feita no item 4.4 deste mesmo capítulo.

De qualquer forma, a grande preocupação está no fato desses setores serem extremamente significativos na Política Nacional de Saúde. Os déficits revelam uma alta vulnerabilidade no setor de saúde, além de contribuir para uma incapacidade competitiva da indústria nacional em um setor tão estratégico. É por isso que o governo vem realizando ações enérgicas de fortalecimento dos laboratórios, como a Portaria 2.438/GM, de 2005, do Ministério da Saúde, que criou a Rede Brasileira de Produção Pública de Medicamentos, mas ainda sem apresentar mudanças significativas.

\subsection{A inovação tecnológica no programa Mais Saúde: aprofundando as políticas de setoriais}

O programa Mais Saúde: Direito de Todos foi lançado pelo Ministério da Saúde em 05 de dezembro de $2007^{92}$, sob a gestão de José Gomes Temporão, no segundo mandato do governo Lula.

\footnotetext{
${ }^{92}$ Ver BRASIL (2007).
} 
O Mais Saúde constitui-se numa reorientação radical da política de saúde, em busca de um grande salto em direção à melhoria das condições de saúde e de vida da população, propiciando maior acesso a serviços e ações de qualidade e tendo como base o papel forte do Estado na universalização da saúde. O novo modelo para o setor saúde está fundamentado nas seguintes iniciativas:

- O setor saúde consolida-se como um campo gerador de empregos ${ }^{93}$, renda e divisas, através do esforço de indução do governo e do engajamento da iniciativa privada;

- Mudança nos processos de gestão das redes e unidades assistenciais, além do acréscimo de mais recursos para prestação de serviços. Propõe novos modelos de gestão, com as fundações estatais de direito privado; novos mecanismos de gerenciamento de processos assistenciais (modernização da regulação do acesso), com o cartão nacional de saúde e a gestão de redes e de territórios assistenciais (TEIAS); o fortalecimento do controle social, com aumento da capacidade dos conselhos de saúde e da ouvidoria e da auditoria, e a diminuição dos vazios assistenciais, das filas de espera, da demora no atendimento, das relações insatisfatórias entre profissionais e usuários;

- Racionalizar e potencializar o uso dos novos recursos, a partir do compartilhamento da gestão e dos investimentos entre Estados e Municípios; estabelecimento de mecanismos formais de contratualização com metas entre os gestores de melhoria da saúde, do atendimento e da qualidade dos serviços.

Os quatro pilares básicos para realização do programa, são

- Pilar 1: promoção e atenção à saúde: a família no centro da mudança.

- Pilar 2: gestão, trabalho e controle social.

- Pilar 3: ampliação do acesso com qualidade.

- Pilar 4: produção, desenvolvimento e cooperação em saúde.

${ }^{93}$ Serão criados mais 3 milhões de novos empregos diretos e indiretos no setor, alcançando 12,5 milhões de postos de trabalho. 
Cada um desses pilares contém metas de investimentos e de ampliação/criação de programas ${ }^{94}$.

Porém, o que nos interessa é a articulação desse programa com o desenvolvimento do CIS e, em especial, com as preocupações voltadas para a inovação dentro das cadeias produtivas desse setor.

Dentre as grandes mudanças de perspectivas para a saúde, encontra-se a mudança da visão, considerada limitada, de que a saúde onera o orçamento público, para pensar a saúde como uma estratégia de desenvolvimento comprometido com o bem-estar social e com o crescimento econômico. Afinal, esse setor não pode mais ser considerado como uma saída de gastos e sim como um setor dinâmico do ponto de vista econômico (GADELHA, 2003). É claro que essa visão não se resume apenas à questão de gastos, mas se insere em uma política de desenvolvimento associada à cidadania plena e à saúde como um direito social básico da cidadania. E esse direito "depende tanto da organização e do funcionamento do sistema de saúde, quanto das condições gerais de vida associadas ao modelo de desenvolvimento vigente" (BRASIL, 2007:5). Assim, o Mais Saúde insere-se na política de desenvolvimento do governo Lula, que pretendia aliar o crescimento econômico com o desenvolvimento e a equidade social (idem).

Em relação ao sistema de proteção social do país, há avanços na inclusão social e na diminuição da pobreza, com reconhecimento pelas diversas e independentes correntes de pensamento, através de programas como o Bolsa Família. Ao mesmo tempo, hoje, a saúde representa um forte impacto econômico na sociedade mundial e por isso mesmo deve estar disposta em um escopo mais amplo, incluindo a diminuição da dependência externa e dos próprios déficits comerciais, que cresceram de maneira acentuada desde a década de noventa ${ }^{95}$. Se observarmos a experiência

\footnotetext{
${ }^{94}$ Essas metas serão sistematizadas e detalhadas posteriormente, devido à grande especificidade por ação.

${ }^{95} \mathrm{Na}$ década de 1990 , todas "as indústrias que fazem parte do complexo industrial da saúde perderam competitividade internacional. $\mathrm{O}$ déficit acumulado cresceu em aproximadamente US $\$ 700$ milhões ao ano, no final dos anos 80, para um patamar superior a US\$ 5 bilhões ao ano, sobretudo para os produtos de maior densidade de conhecimento e tecnologia, a exemplo
} 
internacional, notaremos que a saúde configura-se como um complexo de atividades produtivas de bens e serviços que permitem alavancar segmentoschave da sociedade contemporânea, baseada no conhecimento e na inovação. Segundo o documento Mais Brasil:

A saúde possui, assim, duas dimensões que se associam a uma nova aposta para o desenvolvimento do Brasil. É parte da política social e do sistema de proteção social e fonte de geração de riqueza para o País. O direito à saúde articula-se com um conjunto altamente dinâmico de atividades econômicas que podem se relacionar virtuosamente num padrão de desenvolvimento que busque o crescimento econômico e a equidade como objetivos complementares.

(op. Cit:5)

Para que a saúde seja colocada como um dos pilares de uma estratégia nacional de desenvolvimento, o Mais Saúde definiu lacunas que precisam ser ultrapassadas. Dentre elas, podemos citar: a reduzida articulação da saúde com as demais políticas públicas, pela falta de convergência entre um amplo conjunto de políticas; a presença de uma significativa iniquidade de acesso, sobretudo em relação à orientação, prevenção e tratamento de câncer e de doenças transmissíveis, em grande parte negligenciadas pelos esforços mundiais de pesquisa e produção; a distribuição desigual da oferta de serviços ('vazios assistenciais') pelo território, acompanhando a reprodução das desigualdades sociais e regionais; a fragmentação da descentralização e da municipalização das ações de saúde, com perda de uma visão regionalizada do território; o predomínio de um modelo burocratizado de gestão, segundo o qual o controle ineficiente dos meios ocorre em detrimento dos resultados e da qualidade da atenção à saúde; o subfinanciamento do SUS, tanto pelo gasto per capita quanto pelo preço da consulta médica ou de uma cirurgia; a precarização do trabalho e o baixo investimento na qualificação de recursos humanos, constituindo uma deficiência expressiva que compromete o desempenho do sistema.

de fármacos e medicamentos, equipamentos médicos de base eletrônica, novos materiais (órteses e próteses), hemoderivados, vacinas e reagentes para diagnóstico" (BRASIL, 2007:47). 
Além dessas, a lacuna que gostaríamos de destacar é o descompasso entre a evolução da assistência e a base produtiva e de inovação em saúde. Nesse caso, como já mencionamos no item anterior, a perda de capacidade produtiva e a própria deterioração dos setores ligados à saúde, assim como o fraco desempenho das políticas industriais e de inovação, nas últimas décadas, se apresentam como fatores centrais desse descompasso, carecendo, fundamentalmente, de melhoria. E é nesse sentido que a saúde aparece, não só em um programa específico para a sua área, como é o caso do Mais Saúde, mas também na PITCE; no Plano de Ação do Ministério da Ciência e Tecnologia; em linhas específicas do BNDES, como o Profarma; nos Fundos Setoriais, CT-Saúde e Fundo verde-amarelo; no Estudo da Dimensão Territorial do Planejamento, do Ministério do Planejamento, Orçamento e Gestão; na Política de Desenvolvimento Produtivo, do Ministério do Desenvolvimento da Indústria e Comércio Exterior. Elementos de interinstitucionalidade entre vários ministérios, que ressaltam a urgência de colocar a inovação a serviço da saúde.

O Mais Saúde também contempla sete Eixos Estratégicos, dentre os quais, novamente, o Complexo Industrial da Saúde e a Inovação aparecem como fundamentais e recebem aporte específico de verbas.

Os sete Eixos estão contemplados no Quadro 2, e a saúde se insere no Eixo 3. Apesar de não se tratar do eixo com maior aporte de verbas do programa, já que o mesmo conta com 73 medidas e 165 metas, conta com $\mathrm{R} \$ 89,1$ bilhões, estando $\mathrm{R} \$ 65,1$ bilhões garantidos no Plano Plurianual (PPA) e $\mathrm{R} \$ 24$ bilhões destinados à expansão das ações, para o Complexo da Saúde e Inovação são $R \$ 2$ bilhões, só nesse plano, fora os outros supracitados.

O Eixo 3 tem como diretrizes e estratégias centrais fortalecer o

Complexo Produtivo de Inovação em Saúde, permitindo associar o aprofundamento dos objetivos do Sistema Único de Saúde com a transformação necessária da estrutura produtiva do País, tornando-a compatível com um novo padrão de consumo em saúde e com novos padrões tecnológicos adequados às necessidades da saúde.

(BRASIL, 2007:8) 
O Quadro 3 apresenta de maneira mais estruturada as diretrizes e medidas especificas para esse eixo. 
Quadro 2 - Eixos de Intervenção: diretrizes, medidas e metas prioritárias

\begin{tabular}{|c|c|c|c|}
\hline Dimensões & Eixos & $\mathrm{N}^{\circ}$ de medidas e metas & $\begin{array}{l}\text { Valor Total dos investimentos } \\
\text { (em Reais) }\end{array}$ \\
\hline \multirow[t]{4}{*}{$\begin{array}{l}\text { Amplo conjunto de medidas econômicas e sociais, que } \\
\text { perpassa todos os outros eixos do programa, } \\
\text { articulando saúde e desenvolvimento. }\end{array}$} & EIXO 1 - Promoção da Saúde & $\begin{array}{l}11 \text { medidas } \\
32 \text { metas }\end{array}$ & $\begin{array}{l}\text { 2,2 bilhões, sendo: } \\
\text { Plano Plurianual: } 0,5 \text { bilhão } \\
\text { Expansão: } 1,7 \text { bilhão }\end{array}$ \\
\hline & EIXO 2 - Atenção à Saúde & $\begin{array}{l}27 \text { Medidas } \\
85 \text { Metas }\end{array}$ & $\begin{array}{l}\text { 80,1 bilhões, sendo: } \\
\text { Plano Plurianual: } 60,1 \text { bilhões } \\
\text { Expansão: } 20 \text { bilhões }\end{array}$ \\
\hline & EIXO 3 - Complexo Industrial da saúde & $\begin{array}{l}14 \text { Medidas } \\
15 \text { Metas }\end{array}$ & $\begin{array}{l}2 \text { bilhões, sendo: } \\
\text { Plano Plurianual: } 1,2 \text { bilhão } \\
\text { Expansão: } 0,8 \text { bilhão }\end{array}$ \\
\hline & & TOTAL & $\begin{array}{l}\text { 84,3 bilhões, sendo: } \\
\text { Plano Plurianual: } 61,8 \text { bilhões } \\
\text { Expansão: } 22,5 \text { bilhões }\end{array}$ \\
\hline \multirow{4}{*}{$\begin{array}{l}\text { Eixos que dão suporte à extensão das ações de saúde } \\
\text { (associadas aos Eixos } 1,2 \text { e 3), compondo dois grandes } \\
\text { conjuntos de intervenção como peças estratégicas do } \\
\text { sistema: força de trabalho e gestão. }\end{array}$} & EIXO 4 - Força de trabalho em saúde & $\begin{array}{l}8 \text { Medidas } \\
9 \text { Metas }\end{array}$ & $\begin{array}{l}\text { 2,5 bilhões, sendo: } \\
\text { Plano Plurianual: } 1,7 \text { bilhão } \\
\text { Expansão: } 0,8 \text { bilhão }\end{array}$ \\
\hline & EIXO 5 - Qualificação da gestão & $\begin{array}{l}5 \text { Medidas } \\
11 \text { Metas }\end{array}$ & $\begin{array}{l}\text { 1,9 bilhão, sendo: } \\
\text { Plano Plurianual: } 1,3 \text { bilhão } \\
\text { Expansão: } 0,6 \text { bilhão }\end{array}$ \\
\hline & EIXO 6 - Participação e controle social & $\begin{array}{l}4 \text { Medidas } \\
5 \text { Metas }\end{array}$ & $\begin{array}{l}296 \text { milhões, sendo: } \\
\text { Plano Plurianual: } 267 \text { milhões } \\
\text { Expansão: } 29 \text { milhões }\end{array}$ \\
\hline & & TOTAL & $\begin{array}{l}\text { 4,696 bilhões sendo: } \\
\text { Plano Plurianual: } 3,267 \text { bilhões } \\
\text { Expansão: } 1,429 \text { bilhão }\end{array}$ \\
\hline $\begin{array}{l}\text { Dimensão internacional, inserindo a saúde na política } \\
\text { exterior brasileira. }\end{array}$ & EIXO 7 - Cooperação entre os países & $\begin{array}{l}4 \text { Medidas } \\
8 \text { Metas }\end{array}$ & $\begin{array}{l}58 \text { milhões, sendo: } \\
\text { Plano Plurianual: } 15 \text { milhões } \\
\text { Expansão: } 43 \text { milhões }\end{array}$ \\
\hline$\overline{\text { TOTAL }}$ & & & $\begin{array}{l}89,054 \text { bilhões sendo: } \\
\text { Plano Plurianual: } 65,082 \text { bilhões } \\
\text { Expansão: } 23,972 \text { bilhões }\end{array}$ \\
\hline
\end{tabular}

Fonte: BRASIL. Ministério da Saúde. Programa Mais Saúde: Direito de Todo. 2008-2011. Brasília: MS, dezembro de 2007. (pp.13-81). 


\begin{tabular}{|c|c|c|}
\hline \multicolumn{3}{|c|}{ uadro 3 - Diretrizes e Medidas propostas pelo Mais Saúde para o Complexo Industrial da Saúde } \\
\hline \multirow{8}{*}{$\begin{array}{l}\text { Complexo } \\
\text { Industrial da } \\
\text { Saúde }\end{array}$} & Diretrizes & Medidas \\
\hline & \multirow{7}{*}{$\begin{array}{l}\text { Reduzir a } \\
\text { vulnerabilidade da } \\
\text { política social brasileira } \\
\text { mediante o } \\
\text { fortalecimento do } \\
\text { Complexo Industrial e } \\
\text { de Inovação em Saúde, } \\
\text { associando o } \\
\text { aprofundamento dos } \\
\text { objetivos do Sistema } \\
\text { Único de Saúde com a } \\
\text { transformação } \\
\text { necessária da estrutura } \\
\text { produtiva e de inovação } \\
\text { do País, tornando-a } \\
\text { compatível com um } \\
\text { novo padrão de } \\
\text { consumo em saúde e } \\
\text { com novos padrões } \\
\text { tecnológicos. }\end{array}$} & $\begin{array}{l}\text { 1. Implementar um Programa Nacional para Produção Estratégica do Complexo } \\
\text { Industrial da Saúde, objetivando as necessidades da saúde, articulando o fomento à } \\
\text { inovação e à política de compras governamentais, mediante parceria com o } \\
\text { MDIC/BNDES, o MCT, unidades da federação e o Ministério da Saúde. }\end{array}$ \\
\hline & & $\begin{array}{l}\text { 2. Investir na rede de Laboratórios Oficiais de Medicamentos, estruturando a produção } \\
\text { pública e a transferência de tecnologia de farmoquímicos estratégicos para o País, } \\
\text { incluindo a nacionalização de antirretrovirais e de pelo menos } 50 \% \text { da demanda local } \\
\text { de insulina. }\end{array}$ \\
\hline & & $\begin{array}{l}\text { 3. Investir nos produtores públicos de vacinas, dotando o País de capacitação } \\
\text { tecnológica e competitiva em novos imunobiológicos, com destaque para as vacinas } \\
\text { contra pneumococus, meningo C, dupla viral (sarampo/rubéola), heptavalente, } \\
\text { rotavírus, gripe e meningites e dengue. }\end{array}$ \\
\hline & & $\begin{array}{l}\text { 4. Fomentar a capacidade produtiva e de inovação nas indústrias privadas nacionais de } \\
\text { medicamentos, equipamentos e materiais em parceria com o BNDES e FINEP. }\end{array}$ \\
\hline & & $\begin{array}{l}\text { 5. Regulamentar e alterar a legislação de compras para permitir o uso estratégico do } \\
\text { poder de compra do Estado para produtos inovadores de alta essencialidade para a } \\
\text { saúde. }\end{array}$ \\
\hline & & $\begin{array}{l}\text { 6. Fomentar redes tecnológicas voltadas à regulação e à qualidade dos produtos de } \\
\text { saúde, incluindo laboratórios de testes e certificação de produtos para a saúde. }\end{array}$ \\
\hline & & $\begin{array}{l}\text { 7. Fomentar projetos envolvendo temas de fronteiras, com ênfase no desenvolvimento } \\
\text { de produtos e processos com impacto na indústria e no serviço de saúde (em } \\
\text { cooperação com o MCT para articular inovação e poder de compra). }\end{array}$ \\
\hline
\end{tabular}




\begin{tabular}{|c|c|c|}
\hline \multicolumn{3}{|c|}{ Quadro 3 - Diretrizes e Medidas propostas pelo Mais Saúde para o Complexo Industrial da Saúde (Cont.) } \\
\hline \multirow{7}{*}{$\begin{array}{l}\text { Complexo } \\
\text { Industrial da } \\
\text { Saúde }\end{array}$} & Diretrizes & Medidas \\
\hline & \multirow{6}{*}{$\begin{array}{l}\text { Aumentar a } \\
\text { competitividade em } \\
\text { inovações das } \\
\text { empresas e dos } \\
\text { produtores públicos e } \\
\text { privados das indústrias } \\
\text { da saúde, tornando-os } \\
\text { capazes de enfrentar a } \\
\text { concorrência global, } \\
\text { promovendo um } \\
\text { vigoroso processo de } \\
\text { substituição de } \\
\text { importações de } \\
\text { produtos e insumos em } \\
\text { saúde de maior } \\
\text { densidade de } \\
\text { conhecimento que } \\
\text { atendam às } \\
\text { necessidades de } \\
\text { saúde. }\end{array}$} & $\begin{array}{l}\text { 8. Consolidar a Rede Nacional de Ciência e Tecnologia em Saúde mediante a } \\
\text { expansão institucional da Fiocruz para as regiões menos desenvolvidas do País, } \\
\text { segundo a estratégia de regionalização do desenvolvimento da C\&T em Saúde. } \\
\text { 9. Implantar o Centro de Desenvolvimento Tecnológico em Saúde na Fiocruz. }\end{array}$ \\
\hline & & $\begin{array}{l}\text { 10. Promover e modernizar o Sistema Nacional de Vigilância Sanitária para garantir a } \\
\text { qualidade e a eficiência do processo de produção e de inovação nacional, garantindo a } \\
\text { harmonização regulatória em relação às importações, consoante com a garantia da } \\
\text { qualidade e da segurança dos produtos em saúde. }\end{array}$ \\
\hline & & $\begin{array}{l}\text { 11. Fomentar a criação e a ampliação de duas redes de pesquisa clínica voltadas para } \\
\text { as prioridades do SUS. }\end{array}$ \\
\hline & & $\begin{array}{l}\text { 12. Fomentar a criação de dois centros de toxicologia capazes de atender à demanda } \\
\text { da indústria em itens prioritários para o SUS. }\end{array}$ \\
\hline & & $\begin{array}{l}\text { 13. Fomentar a criação de uma rede de biotério de alto desempenho no País (em } \\
\text { cooperação com o Ministério da Ciência e Tecnologia). }\end{array}$ \\
\hline & & $\begin{array}{l}\text { 14. Concluir o investimento na Hemobrás possibilitando ao País o domínio da } \\
\text { tecnologia de fracionamento industrial do plasma e aumentando o grau de } \\
\text { autossuficiência em hemoderivados. }\end{array}$ \\
\hline
\end{tabular}


Ao todo são 14 medidas que pretendem ser contempladas a partir do Mais Saúde, dentre as quais algumas merecem atenção especial. Em primeiro lugar, podemos observar que o plano conta sempre com um tratamento envolvendo variadas instituições federais para a sua execução; como exemplo podemos citar as medidas 1 (MS, MDIC, BNDES e MCT), a 2 (BNDES e FINEP), 7 e 13 (MCT). Ou seja, é um indício importante de articulação entre as políticas dessas instituições, no sentido de promover um desenvolvimento baseado na inovação como um dos pilares fundamentais.

Em segundo lugar, ganha relevância o conjunto de medidas que fortaleçam a produção nacional privada e pública de medicamentos, farmoquímicos, antirretrovirais, vacinas, equipamentos e materiais (medidas 2, 3 e 4). Por fim, as medidas (2, 3, ,8, 9, 10 e 13), que visam a ampliação da capacidade de produção e da vigilância nacional pública, através da expansão da Fiocruz, da viabilização da produção de vacinas, do fortalecimento e modernização do Sistema Nacional de Vigilância Sanitária (muito criticado pelos produtores de medicamentos, por sua morosidade na definição das análises) e o investimento na Hemobrás.

Assim, o PAC Saúde, como ficou conhecido o plano, teve como objetivo aproveitar as potencialidades do setor saúde dentro um novo padrão de desenvolvimento para o Brasil, em que a política de saúde entrou em consonância com a política de desenvolvimento econômico, constituindo uma frente de expansão que vincula o desenvolvimento econômico ao social, inserindo-se em uma estratégia nacional de desenvolvimento mais ampla, com acepção ao desenvolvimento tecnológico em áreas estratégicas. Esse plano também chamou a atenção pela forte institucionalidade, já que previa ações em parceria com diversas instituições. Seus desdobramentos constituem uma análise fundamental da efetividade dessa política. 


\subsection{A saúde no PAC Inovação - Plano de Ação em Ciência, Tecnologia e Inovação 2007-2010}

Os incentivos e planos federais que tem a inovação como uma de suas principais preocupações são variados, como já demonstramos anteriormente. Porém, houve também o lançamento de uma política específica para inovação, que se intitula "Plano de Ação 2007-2010, 'Ciência, tecnologia e Inovação para o Desenvolvimento Nacional'” (PACT\&I 2007-2010). A política é uma iniciativa do MCT e suas agências relacionadas, com previsão de funcionar em parceria com outros ministérios, estados, municípios e setor empresarial, tendo ainda a participação de outras entidades governamentais como o BNDES e a Petrobrás ${ }^{96}$.

Em relação aos recursos, a previsão é de que serão investidos mais de $\mathrm{R} \$ 41$ bilhões. Podemos observar, a partir do Gráfico 7, que a participação do MCT é substancialmente maior do que a das outras instituições, tendo cerca de $46 \%$ do total de recursos disponíveis para o plano. Também são consideráveis as participações do BNDES, através de várias linhas de apoio à inovação, e do Ministério de Minas e Energia (MME) junto à Petrobras e à CEPEL, afinal uma das linhas estratégicas diz respeito às fontes de energia. Apesar da FINEP não aparecer de forma isolada, foi previsto um orçamento de $\mathrm{R} \$ 800$ milhões só em operações de créditos que, se somados aos recursos disponíveis para subvenção econômica, para o capital de risco e para a redução dos juros de empréstimos, o montante total chega à casa dos $\mathrm{R} \$ 1,5$ bilhão.

\footnotetext{
${ }^{96} \mathrm{Na}$ linha de ação voltada para a saúde, os ministérios que aparecem como participantes são: MS, MDIC, MAPA e MMA. Outras instituições são: CGEE, FIOCRUZ, Butantan, FINEP e CNPq.
} 


\section{Gráfico 7 - Recursos disponibilizados para execução do PACT\&I}

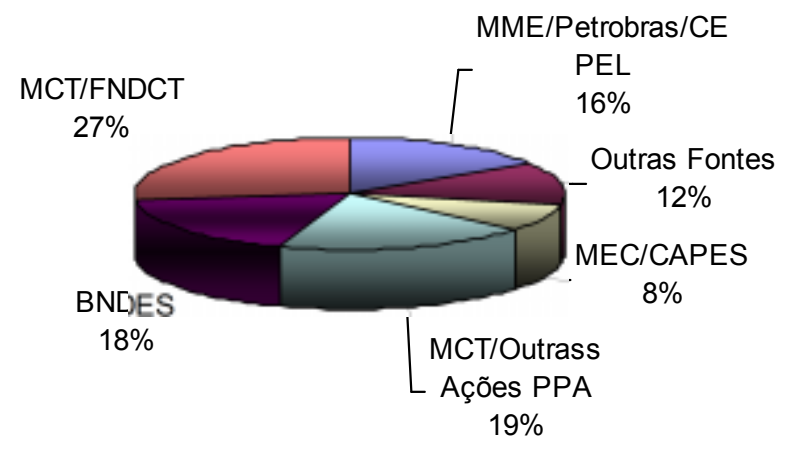

Fonte: BRASIL (2007a)

Suas prioridades vão ao encontro dos quatro eixos que integram a Política Nacional de C,T\&I e estão sintetizadas no PACT\&I:

- expandir, integrar, modernizar e consolidar o Sistema Nacional de Ciência e Tecnologia e Inovação (SNCTI), atuando em articulação com os governos estaduais para ampliar a base científica e tecnológica nacional;

- atuar de maneira decisiva para acelerar o desenvolvimento de um ambiente favorável à inovação nas empresas, fortalecendo a Política Industrial, Tecnológica e de Comércio Exterior (PITCE);

- fortalecer as atividades de pesquisa e inovação em áreas estratégicas para a soberania do País, em especial energia, aeroespacial, segurança pública, defesa nacional e Amazônia;

- promover a popularização e o ensino de ciências, a universalização do acesso aos bens gerados pela ciência e a difusão de tecnologias para a melhoria das condições de vida da população.

Através dessas prioridades, o plano pretende atingir quatro metas principais. A primeira é conseguir aumentar os investimentos em P\&D globais para P\&D interno de $1,02 \%$, em 2006 , para $1,5 \%$ do PIB. A segunda diz 
respeito à ampliação da participação empresarial de 0,51\%, em 2006, para 0,65\% do PIB, do total de investimentos em P\&D. A terceira é fortalecer a formação de recursos humanos, através da elevação do número de bolsas concedidas pelo CNPq, de 68.000, em 2007, para 105.000 em 2010, dando ênfase às engenharias e áreas relacionadas à PITCE. E, por último, fortalecer as iniciativas de C\&T para o desenvolvimento social, através da implementação de 400 centros vocacionais tecnológicos e 600 telecentros, além da ampliação da Olimpíada de Matemática. É importante deixar claro que essas metas são tidas como as mais amplas, tendo cada área estratégica metas particulares a atingir, como no caso dos Insumos para a Saúde, e que serão retratadas adiante.

É evidente que uma das maiores dificuldades para a criação de um sistema nacional de inovação está nos baixos investimentos que as empresas destinam a PD\&I. Entre as principais causas, estão os altos custos de investimento aliados às baixas garantias de retorno, ou seja, os riscos de investimento se configuram como o maior obstáculo à inovação, segundo análise da PINTEC realizada por Luna, Moreira e Gonçalves (2008:231). Mas, como já ressaltamos, as políticas governamentais são fundamentais para o aumento dos investimentos em inovação. É nesse sentido que Arbix (2007:26) aponta que a baixa intensidade do conhecimento envolvido na inovação tecnológica no Brasil encontra-se no fato de não termos "mecanismos de apoio nem linhas de financiamentos adequadas para a inovação nas empresas”.

Parte desses problemas foi abordada no capítulo 3 sobre subvenção, as leis e os fundos criados recentemente visando o aumento dos investimentos em inovação nas empresas. De outra forma, o PACT\&I também apresenta possíveis formas de operacionalização, a partir de instrumentos institucionais e financeiros disponibilizados para as empresas, para dar mais robustez ao mesmo. São cinco os instrumentos priorizados pelo plano e sistematizados e comentados no Quadro 4. Vários desses instrumentos já foram abordados em outros momentos, mas o poder de compra merece destaque, tendo em vista a fragilidade pela qual o setor farmacêutico nacional vem passando nos últimos anos. 
No seminário 'Complexo Econômico-Industrial da Saúde', realizado em maio de 2008 pelo BNDES e Ministério da Saúde, com a participação de representantes do poder público e da esfera privada, esse tema foi enfatizado por membros de todas as representações. As proposições apontavam para que o poder de compra do Estado fosse um instrumento eficiente na diminuição das importações e consequente redução da dependência externa, através do desenvolvimento de atividades inovativas estratégicas para o setor dentro do Brasil. Ao final desse item voltaremos a essa discussão.

Retomando o plano, para uma melhor análise, principalmente no que tange às questões relacionadas com a saúde, demonstraremos a sua estrutura e posteriormente faremos um aprofundamento dos cinco eixos específicos para a opção estratégica Insumos para a Saúde.

A estrutura do plano é definida a partir de três prioridades estratégicas, entre as quais a saúde aparece na 'Pesquisa, Desenvolvimento e Inovação em Áreas Estratégicas', na linha 9 de ação (Quadro 5). 


\begin{tabular}{|c|c|c|}
\hline \multicolumn{3}{|c|}{ Quadro 4 - Instrumentos de Auxilio à Inovação Propostos pelo PACT\&I 2007-2010 } \\
\hline Instrumentos & Principais Medidas & Comentários \\
\hline $\begin{array}{l}\text { Financiamento } \\
\text { com juros } \\
\text { reais } \\
\text { reduzidos }\end{array}$ & $\begin{array}{l}\text { ampliação na escala de recursos destinados ao apoio à inovação em empresas, } \\
\text { mobilizados pela FINEP (Fundos Setoriais, FAT, etc.), e em parcerias com } \\
\text { entidades financeiras públicas (Banco do Brasil, Caixa Econômica Federal, Banco } \\
\text { do Nordeste, Banco da Amazônia, inclusive com a utilização dos Fundos } \\
\text { Constitucionais voltados para o desenvolvimento regional) e privadas; } \\
\text { ampliação e consolidação da participação do BNDES no financiamento da P\&D e } \\
\text { da inovação nas empresas, assim como na capitalização de empresas de base } \\
\text { tecnológica; }\end{array}$ & $\begin{array}{l}\text { Apesar de aparecer como uma medida central, esses } \\
\text { recursos já vem sendo mobilizados pela FINEP e BNDES, } \\
\text { mas vale ressaltar a aceleração e aumento da disposição } \\
\text { dos mesmos. } \\
\text { A disponibilidade de financiamentos privados para inovação, } \\
\text { segundo Luna, Moreira e Gonçalves (2008) ainda é } \\
\text { extremamente baixa, representando menos de } 5 \% \text { dos } \\
\text { financiamentos em P\&D pelas empresas. Nesse ponto, } \\
\text { observa-se que esse ajuste será de difícil solução e } \\
\text { efetivação. }\end{array}$ \\
\hline $\begin{array}{c}\text { Capital } \\
\text { empreendedor }\end{array}$ & $\begin{array}{l}\text { ampliação de fundos de capital empreendedor (private equity, venture capital, } \\
\text { capital semente e anjos) dedicados à inovação, através da FINEP e do BNDES, } \\
\text { assim como pela mobilização de recursos de bancos de investimento, fundos de } \\
\text { pensão e seguradoras nacionais e estrangeiras; }\end{array}$ & $\begin{array}{l}\text { Programas como o Profarma do BNDES já apresentam } \\
\text { linhas para capital semente. }\end{array}$ \\
\hline $\begin{array}{l}\text { Incentivos } \\
\text { fiscais }\end{array}$ & $\begin{array}{l}\text { ampliação do uso de incentivos fiscais para a promoção da P\&D e da inovação, em } \\
\text { especial, por intermédio da consolidação das oportunidades criadas pelo novo } \\
\text { marco regulatório na área de ciência e tecnologia; }\end{array}$ & $\begin{array}{l}\text { Os incentivos fiscais ainda permanecem restritos à Lei de } \\
\text { Inovação e Lei do Bem, não tendo sido criado até o mento } \\
\text { nenhum outro. Na linha de ação } 1 \text { também estava prevista a } \\
\text { criação da Lei de Regulamentação do FNDCT, aprovada em } \\
\text { abril de 2007, junto ao Decreto } n^{\circ} 6.090 \text { de } 24 / 04 / 2007 \text {, que } \\
\text { altera a composição e aprova o novo Regimento do } \\
\text { Conselho Nacional de Ciência e Tecnologia }{ }^{97} \text {. }\end{array}$ \\
\hline $\begin{array}{l}\text { Subvenção } \\
\text { econômica }\end{array}$ & $\begin{array}{l}\text { aperfeiçoamento e consolidação do uso dos mecanismos de subvenção } \\
\text { econômica às atividades de P,D\&l e ao emprego de pesquisadores em empresas; }\end{array}$ & $\begin{array}{l}\text { Além da subvenção econômica já estar sendo realizada pela } \\
\text { Lei de Inovação e Lei do Bem, a FINEP criou o Programa de } \\
\text { Subvenção Econômica às Empresas, que visa diminuir os } \\
\text { riscos dos investimentos em inovação. }\end{array}$ \\
\hline $\begin{array}{l}\text { Poder de } \\
\text { compra do } \\
\text { setor público }\end{array}$ & $\begin{array}{l}\text { promover o desenvolvimento tecnológico das empresas brasileiras, tanto por } \\
\text { intermédio da compra direta de produtos e processos inovadores (como permitido } \\
\text { pela Lei de Inovação), quanto pelo estabelecimento de contrapartidas de acesso a } \\
\text { tecnologias e na aquisição pelo governo, no exterior, de significativos lotes de } \\
\text { produtos ou serviços. Setor Farmacêutico é um dos prioritários }\end{array}$ & $\begin{array}{l}\text { Esse item vem sendo amplamente discutido, principalmente } \\
\text { nas políticas ligadas ao Complexo Industrial da Saúde, com } \\
\text { ênfase no Profarma, dados os problemas que enfrentamos } \\
\text { no setor farmacêutico. Ressalta-se ainda a importância } \\
\text { desse setor para os gastos da saúde pública brasileira. }\end{array}$ \\
\hline
\end{tabular}

${ }^{97}$ Com esse decreto ficou instituído seu caráter de órgão de assessoramento superior do Presidente da República para a formulação e a implementação da Política Nacional de Desenvolvimento Científico e Tecnológico. Assim, as reuniões plenárias tenderão a ser mais regulares e contarão com as presenças do Conselho Nacional de Secretários Estaduais para Assuntos de CT\&I (Consecti) e do Conselho Nacional das Fundações Estaduais de Amparo à Pesquisa ( Confap). 


\section{Quadro 5 - Plano de Ação 2007-2010 MCT - Prioridades Estratégicas e Linhas de Ação}

\begin{tabular}{|c|c|}
\hline $\begin{array}{l}\text { Prioridades } \\
\text { Estratégicas }\end{array}$ & Linhas de Ação \\
\hline $\begin{array}{l}\text { I - Expansão e } \\
\text { Consolidação do } \\
\text { Sistema Nacional de } \\
\text { C,T\&l }\end{array}$ & $\begin{array}{l}\text { 1. Consolidação Institucional do Sistema Nacional de C,T\&I } \\
\text { 2. Formação de Recursos Humanos para C,T\&I } \\
\text { 3. Infraestrutura e Fomento da Pesquisa Científica e Tecnológica }\end{array}$ \\
\hline $\begin{array}{l}\text { Il - Promoção da } \\
\text { Inovação Tecnológica } \\
\text { nas Empresas }\end{array}$ & $\begin{array}{l}\text { 4. Apoio à Inovação Tecnológica nas Empresas } \\
\text { 5. Tecnologia para a Inovação nas Empresas } \\
\text { 6. Incentivo à Criação e à Consolidação de Empresas Intensivas em } \\
\text { Tecnologia }\end{array}$ \\
\hline $\begin{array}{l}\text { III - Pesquisa, } \\
\text { Desenvolvimento e } \\
\text { Inovação em Áreas } \\
\text { Estratégicas }\end{array}$ & $\begin{array}{l}\text { 7. Áreas Portadoras de Futuro: Biotecnologia e Nanotecnologia } \\
\text { 8. Tecnologias da Informação e Comunicação } \\
\text { 9. Insumos para a Saúde } \\
\text { 10. Biocombustíveis } \\
\text { 11. Energia Elétrica, Hidrogênio e Energias Renováveis } \\
\text { 12. Petróleo, Gás e Carvão Mineral } \\
\text { 13. Agronegócio } \\
\text { 14. Biodiversidade e Recursos Naturais } \\
\text { 15. Amazônia e Semiárido } \\
\text { 16. Meteorologia e Mudanças Climáticas } \\
\text { 17. Programa Espacial } \\
\text { 18. Programa Nuclear } \\
\text { 19. Defesa Nacional e Segurança Pública }\end{array}$ \\
\hline $\begin{array}{l}\text { IV - C,T\&I para o } \\
\text { Desenvolvimento } \\
\text { Social }\end{array}$ & $\begin{array}{l}\text { 20. Popularização da C,T\&l e Melhoria do Ensino de Ciências } \\
\text { 21. Tecnologias para o Desenvolvimento Social }\end{array}$ \\
\hline
\end{tabular}

Fonte: Brasil, 2007b

Os objetivos mais gerais ligados aos Insumos para a Saúde estão relacionados ao fortalecimento do Complexo Industrial da Saúde. Ou seja, há uma visão da saúde ancorada principalmente na expansão da indústria brasileira, no aumento da competitividade, na maior participação do setor no mercado internacional, no próprio crescimento da economia nacional e na geração de postos de trabalhos. Os mecanismos e instrumentos de efetivação e execução dessa linha estão de acordo com os instrumentos apresentados no Quadro 6. São apresentadas propostas de definição de marcos regulatórios, linhas de créditos, criação de incentivos fiscais e tributários específicos aos setores ligados à saúde. 
A inovação ganha papel de destaque principalmente na formação de sistemas de inovação que fortaleçam a ampliação de plataformas tecnológicas e melhorem a capacitação de recursos humanos capazes de promover um melhor gerenciamento empresarial de P,D\&I para o Complexo IndustrialEconômico da Saúde e, como consequência, do desenvolvimento nacional. Ainda que os resultados sejam insatisfatórios e algumas lacunas nas execuções dos planos sejam visíveis, o esforço nacional deve ser repensando e constantemente avaliado. 


\begin{tabular}{|c|c|c|c|c|}
\hline \multicolumn{5}{|c|}{ Quadro 6 - Especificação dos Programas da Linha de Ação “Insumos para a Saúde”, definida pelo PACT\&I 8007-2010 } \\
\hline Programas & Principais Objetivos $^{98}$ & $\begin{array}{l}\text { Origem e Valor } \\
\text { dos Recursos }\end{array}$ & $\begin{array}{l}\text { Instituições } \\
\text { Participantes }\end{array}$ & $\begin{array}{l}\text { Agências } \\
\text { Executoras }\end{array}$ \\
\hline $\begin{array}{l}\text { 9.1 Fármacos e } \\
\text { Medicamentos }\end{array}$ & $\begin{array}{l}\text { Estimular pesquisa, desenvolvimento e transferência tecnológica para melhoria } \\
\text { da inovação em empresas nacionais. Melhorar o controle de qualidade da } \\
\text { produção nacional de medicamentos e fármacos, visando melhor } \\
\text { competitividade internacional. }\end{array}$ & $\begin{array}{l}\text { MCT/FNDCT } \\
\text { R\$ 35,08 milhões }\end{array}$ & $\begin{array}{l}\text { CGEE/MS } \\
\text { MDIC/MAPA } \\
\text { MMA/FIOCRUZ } \\
\text { Butantan }\end{array}$ & $\begin{array}{l}\text { FINEP } \\
\text { CNPq }\end{array}$ \\
\hline $\begin{array}{l}\text { 9.2 Produtos } \\
\text { Médicos e } \\
\text { Biomateriais }\end{array}$ & $\begin{array}{l}\text { Desenvolvimento tecnológico e inovação para o setor em produtos considerados } \\
\text { estratégicos pelo Ministério da Saúde. }\end{array}$ & $\begin{array}{l}\text { MCT/FNDCT } \\
\mathrm{R} \$ 1,60 \text { milhões }\end{array}$ & $\begin{array}{l}\text { CGEE/MS } \\
\text { MDIC/MAPA } \\
\text { MMA/ FIOCRUZ } \\
\text { Associações } \\
\text { empresariais }\end{array}$ & $\begin{array}{l}\text { FINEP } \\
\text { CNPq }\end{array}$ \\
\hline $\begin{array}{l}9.3 \text { Kits } \\
\text { Diagnósticos }\end{array}$ & $\begin{array}{l}\text { Estimular o desenvolvimento tecnológico e a produção nacional de insumos e } \\
\text { reativos diagnósticos para ensaios enzimáticos, ensaios moleculares e testes } \\
\text { rápidos, com foco em doenças negligenciadas ou de grande impacto econômico } \\
\text { sobre o sistema de saúde do País, visando à diminuição das importações. }\end{array}$ & $\begin{array}{l}\text { MCT/FNDCT } \\
\text { R\$ } 10,80 \text { milhões }\end{array}$ & $\begin{array}{l}\text { MS } \\
\text { MDIC/MAPA } \\
\text { MMA/ FIOCRUZ } \\
\text { Associações } \\
\text { empresariais }\end{array}$ & $\begin{array}{l}\text { FINEP } \\
\text { CNPq }\end{array}$ \\
\hline $\begin{array}{l}9.4 \\
\text { Hemoderivados }\end{array}$ & $\begin{array}{l}\text { Estimular a produção nacional dos hemoderivados de forma a atender às } \\
\text { demandas de saúde pública, além de promover o desenvolvimento tecnológico } \\
\text { e a inovação desses produtos, em sintonia com a Política de Desenvolvimento } \\
\left.\text { da Biotecnologia (Decreto } n^{\circ} 6.041 / 2007\right) \text { e com a Política Industrial Tecnológica } \\
\text { e de Comércio Exterior - PITCE. }\end{array}$ & $\begin{array}{l}\text { MCT/FNDCT } \\
\mathrm{R} \$ 4,40 \text { milhões }\end{array}$ & $\begin{array}{l}\text { MS } \\
\text { MDIC/MAPA } \\
\text { MMA/ FIOCRUZ } \\
\text { Associações } \\
\text { empresariais }\end{array}$ & $\begin{array}{l}\text { FINEP } \\
\text { CNPq }\end{array}$ \\
\hline 9.5 Vacinas & $\begin{array}{l}\text { Estimular o desenvolvimento tecnológico e a produção nacional de vacinas para } \\
\text { uso humano, promovendo a agregação de novas tecnologias e a ampliação da } \\
\text { capacidade de produção nacional para buscar a diminuição da dependência de } \\
\text { importação, o incremento da capacidade científica nacional e o desenvolvimento } \\
\text { de novas tecnologias. }\end{array}$ & $\begin{array}{l}\text { Não explicitado } \\
\text { origem e valor } \\
\text { dos recursos }\end{array}$ & $\begin{array}{l}\text { MS } \\
\text { MDIC/MAPA } \\
\text { MMA/ FIOCRUZ } \\
\text { Associações } \\
\text { empresariais }\end{array}$ & $\begin{array}{l}\text { FINEP } \\
\text { CNPq }\end{array}$ \\
\hline
\end{tabular}

\footnotetext{
${ }^{98}$ Os itens 9.2, 9.4 e 9.5 estão em sintonia com a Política de Desenvolvimento da Biotecnologia (Decreto ${ }^{\circ}$ 6.041/2007) e com a Política Industrial Tecnológica e de Comércio Exterior - PITCE. Já o item 9.3 está em sintonia apenas com a Política de Desenvolvimento da Biotecnologia (Decreto $\left.n^{\circ} 6.041 / 2007\right)$
} 
Em primeiro lugar, segundo o Plano, para os cinco programas, o Ministério da Saúde definiu recursos globais de $\mathrm{R} \$ 800$ milhões, mas nem sequer estão explicitadas as quantias referentes a cada programa, tampouco se esses recursos serão administrados pelo o MCT, pelo MS ou por qualquer outra instituição. Ainda na questão dos recursos, fica evidente que, em alguns casos, como o dos programas para Produtos Médicos, Biomateriais e para Hemoderivados, as quantias são extremamente baixas, tendo em vista seus objetivos; afinal, impulsionar atividades inovativas em lista de produtos (que, por sua vez, contam com uma série de produtores) apenas com recursos da ordem de $\mathrm{R} \$ 1,6$ milhões, parece ser impossível.

Em segundo lugar, não fica clara a atuação de outros ministérios, ou seja, quais secretarias ou mesmo agências a eles relacionadas serão agentes e quais serão suas funções, principalmente pelo fato de serem questões específicas, tratadas em áreas complexas de produção, o que muito dificulta uma análise da execução desses programas.

Em terceiro lugar, no programa de Fármacos e Medicamentos não há a participação nem da ANVISA nem do Instituto Nacional de Propriedade Intelectual (INPI), instituições fundamentais para a liberação de novos produtos. No capítulo anterior, verificamos que, entre as críticas realizadas às dificuldades de inovar feitas por uma empresa da Subvenção, a ANVISA obteve destaque.

Por fim, é curioso o fato do Butantan não participar nem do programa de Hemoderivados nem do programa de Vacinas. Indiferente de ser um órgão estadual, partindo do pressuposto de que é um dos maiores produtores de vacinas e hemoderivados do Brasil e do mundo, essa instituição deveria estar contemplada. Inclusive pelo fato dela mesma ser citada na própria descrição do programa como uma das duas maiores instituições produtoras de vacinas no Brasil, ao lado da FIOCRUZ, além de conter o exemplo da DTP (vacina tríplice com surfactante) que já está sendo produzida para utilização na Argélia e no Paquistão. 
No tocante à estrutura dos programas, o documento apresenta uma divisão: Objetivo Geral, Descrição do Programa, Atividades Planejadas, Metas, Parceiros e Agências Executoras. O primeiro e os dois últimos estão relacionados no Quadro 6. Já a descrição do programa apresenta, de forma resumida, os principais pontos que dão destaque à importância dos temas vinculados ao PACT\&l, porém de maneira muito ampla. Sendo assim, pensamos ser mais interessante realizar a análise dos itens presentes no Quadro 6, sobretudo os relacionados à origem dos recursos; às instituições participantes e executoras. $O$ total de recursos destinados aos seis programas é da ordem de $R \$ 50$ milhões e alguns deles se encontram em execução nos editais do CNPq, nas Chamadas Públicas da FINEP, que são as únicas agências de execução. Chama a atenção a diversidade de instituições partícipes desses programas, o que, por sua vez, revela uma interinstitucionalidade e visão estratégica da saúde para além da atuação das instituições específicas da área.

Finalmente, apontamentos sobre o poder de compra do Estado se fazem necessários. Partindo do pressuposto de que a política pública de saúde no Brasil é universal, os gastos do setor são vistos como potenciais indutores de investimentos em inovação tecnológica em empresas produtoras de bens e serviços para a saúde. Porém, na prática, a questão não é de tão fácil resolução.

Em primeiro lugar, para que o poder de compra do Estado seja efetivamente indutor, a simbiose entre os serviços de saúde e os produtores deveria acontecer de forma muito mais incisiva e isso não pudemos observar em alguns casos estudados. Por se tratar de entidades públicas, as licitações, que seriam a forma para acessar o poder de compra do Estado, não são pensadas de maneira a efetivar incentivos às empresas menores e inovadoras. Geciane Porto ${ }^{99}$ nos fornece um exemplo dessa dificuldade. A presidente da Fipase afirma haver um problema estrutural no sistema licitatório para o setor de Equipamento Médico Hospitalar e Odontológico (EMHO) que dificulta o acesso das empresas de menor porte ao poder de compra do Estado. Por

${ }^{99}$ Entrevista realizada no dia 10 de agosto de 2009 com Geciane Porto, presidente da Fundação Instituto Pólo Avançado de Saúde de Ribeirão Preto. 
realizar as licitações em grandes blocos, os prestadores acabam por favorecer distribuidoras, que são empresas especializadas em aglutinar os produtos demandados pelas licitações e em oferecer preços menores por item, já que promovem a venda de vários produtos e realizam o contato com diversas empresas produtoras. Nesse caso, saem perdendo as empresas produtoras, que, por ter dificuldade de acesso ao edital, acabam forçadas a vender seus produtos pelo preço negociado pela distribuidora, muitas vezes abaixo do preço de mercado, ou mesmo abaixo de uma margem de lucro que possibilite investimentos em P\&D para promoção de inovações futuras. De outra forma, por não haver muitas empresas produtoras, os distribuidores vendem por preços mais altos, fazendo com que tanto empresas, que vendem barato, quanto hospitais, que compram mais caro, saiam perdendo. Outro ponto de vista é o das multinacionais.

As multinacionais, em primeira instância, já entram com financiamento próprio, ou seja, além de fornecer uma vasta gama de produtos, ainda têm capacidade financeira para diluir custos. Então, compra-se um equipamento que usa reagentes, cujo fornecedor do equipamento é uma multinacional e esse reagente é de tipo importado. Quando atentamos para a balança comercial, contatamos que importamos produtos básicos como soro. Além da compra do equipamento, oneramos nossa balança com a aquisição desses insumos. O valor do equipamento pode até não ser tão alto, mas ficamos dependentes da compra dos insumos nele utilizados. Que fique claro que não pretendemos defender uma política protecionista, mas apenas pensar possibilidades de competição mais igualitárias, de maneira que empresas menores tenham acesso ao mercado.

Uma saída interessante para o uso do poder de compra, apontada por Geciane Porto, seria, além da fragmentação dos editais em vários pedidos, a utilização de um mecanismo que favorecesse a inovação tecnológica para as empresas que vendem aos hospitais públicos, de maneira que essas empresas tivessem obrigação de investir um percentual do seu faturamento em desenvolvimento tecnológico. Essa forma, inclusive, não está em desacordo 
com regras da Organização Mundial do Comércio, já que não se trata de protecionismo, mas de indução de inovação tecnológica.

Em relação ao processo licitatório, Zich Moyses ${ }^{100}$ apontou principalmente duas importantes mudanças que favoreceriam o CEIS: mudanças na lei que regula as licitações brasileiras, a Lei 8666, e definição ainda mais especifica para desenvolvimento tecnológico dos produtos da Portaria N ${ }^{0}$ 978, de 16 de maio de 2008, do Ministério da Saúde ${ }^{101}$. Na opinião do diretor, houve avanços significativos com o lançamento das políticas para inovação tecnológica, da mesma forma que com as linhas de financiamento do BNDES ou as políticas de subvenção econômica da FINEP. Porém, a questão é que os resultados provavelmente ainda continuarão abaixo das expectativas, na medida em que não forem realizadas adaptações nos atuais padrões de poder de compra do Estado e não forem definidos, com maiores especificidades, produtos estratégicos. E isso só seria possível com as duas mudanças supracitadas.

Os exemplos utilizados por Zich Moyses foram o da política de vacinas, apontada como eficiente e muito balizada pela busca da autossuficiência da produção nacional e, por outro lado, a questão dos fármacos excepcionais, em que temos um déficit de $\mathrm{R} \$ 3$ bilhões, para atender a uma parcela muito reduzida da população, ou seja, seria esta uma prioridade de produção nacional. Nesse sentido, o Ministério da Saúde já realiza uma proposta de alteração da Lei 8666 em relação à saúde e, especificamente, à produção de fármacos. A proposta já foi aprovada pelo GECIS e deve ser encaminhada em breve à Presidência da República. Já no que diz respeito à lista de produtos estratégicos, definidos pela Portaria $N^{\circ}$ 978, o Diretor apontou a necessidade de verificar, com urgência, possíveis quebras de monopólio e, dentro da própria lista, criar prioridades ainda mais especificas, sobretudo pelo fato de considerar inviável a dispensa de licitação para todos os produtos da lista. Dada essa

\footnotetext{
100 Entrevista realizada no dia 19 de agosto de 2009 com Zich Moyses Junior, Diretor do Departamento do Complexo Industrial e Inovação em Saúde da Secretaria de Ciência Tecnologia e Insumos Estratégicos do Ministério da Saúde.

${ }^{101}$ Dispõe sobre a lista de produtos estratégicos, no âmbito do Sistema Único de Saúde, com a finalidade de colaborar com o desenvolvimento do Complexo Industrial da Saúde e institui a Comissão para Revisão e Atualização da referida lista.
} 
definição, também, seria possível o lançamento de editais de subvenção, linhas de créditos especificas que possivelmente seriam muito mais eficientes e amarradas aos principais gargalos do setor. Não foram apontados produtos específicos, mas sim a extrema relevância dessa proposta como o futuro da política de saúde brasileira.

Outro debate que tem ganhado força na questão do poder de compra, diz respeito aos gastos em saúde realizados no Brasil. Parece ser óbvio que o rol de gastos que o setor saúde contempla é muito grande. São contabilizados gastos com pagamento de pessoal, compra de equipamentos, manutenção, compra de medicamentos e outros. A discussão central, portanto, é se efetivamente há condições, com o volume de gastos que temos hoje, de financiamento da inovação para além do que se dispende com assistência. $O$ último relatório publicado pela Organização Mundial da Saúde (OMS) ${ }^{102}$ apresenta um quadro desfavorável para o Brasil. Se observarmos países com sistemas públicos de saúde avançados, como o Reino Unido e o Canadá, o percentual do PIB gasto com saúde, para o ano de 2006, foi da ordem de $8,2 \%$ e $10 \%$, respectivamente, sendo que, desses, os gastos governamentais representaram $87,3 \%$ e 70,4\%, também respectivamente. Já o Brasil, no mesmo período, além de apresentar um gasto em saúde em relação ao PIB inferior, cerca de $7,5 \%$, os gastos públicos foram ainda mais baixos, apenas $47,9 \%$ do total. Se comparados os dados de 2000 e 2006, os três países apresentaram aumento dos gastos, mas ainda assim, o Brasil ficou abaixo. Quando comparamos os gastos em saúde per capta (PPC) em dólares, as diferenças são ainda mais gritantes: Reino Unido com US\$2.815, Canadá, com US\$ 3.673 e Brasil, com apenas US\$ 674.

Apesar das estatísticas desfavoráveis, há uma previsão de aumento dos gastos do Estado em saúde para 5\%, em 2012, e 7\%, em 2022. Porém, a situação atual ainda é muito pouco favorável, afinal, de 2000 para 2006, os gastos cresceram apenas $0,3 \%$ no total do PIB e 7,9\% dos gastos públicos. O setor de EMHO, por exemplo, é um dos que assume importância nos gastos públicos, já que $44 \%$ de todas as suas vendas são para o setor público, o que,

${ }^{102} \operatorname{Ver}$ OMS (2009). 
por enquanto, ainda não se reverteu em avanços para o desenvolvimento do setor, que continua com base familiar, pautada em pequenas e médias empresas.

Vale ressaltar também, que uma série de políticas públicas recentes vem sendo aplicada na saúde e os dados supracitados não as contemplam. Para ilustrar, podemos usar o caso do modelo de Subvenção Econômica que, nos últimos anos, tem aplicado recursos para o desenvolvimento de inovações na saúde, conforme apontamos no capítulo anterior. Os recursos destinados para a saúde até o ano de 2009, pela FINEP, como já observamos, totalizaram aproximadamente $\mathrm{R} \$ 204,5$ milhões. Esse aporte pode ser considerado relativamente significativo, sobretudo pelo fato de se tratar de recursos não reembolsáveis de uso exclusivo para inovação tecnológica.

De qualquer forma, é importante ressaltar que essa constituição de uma verdadeira política industrial para a saúde é algo muito recente e que suas definições e desdobramentos ainda são difíceis de serem acessadas. $O$ caso da indústria farmacêutica analisada no início deste capítulo evidencia esse fato. Não menos importantes, também, são os exemplos que utilizamos para a melhoria do poder de compra, que se configuram como políticas em fase de constituição e dependem de mecanismos jurídicos complexos e, portanto não serão resolvidos em um curto espaço de tempo.

\subsection{Cenário atual no Brasil e a política paulista de Parques Tecnológicos para a saúde}

Neste subcapítulo, pretendemos abordar o atual cenário dos gastos relativos às atividades de Pesquisa e Desenvolvimento (P\&D) no Brasil, assim como as diferenças na condução das políticas nacionais de incentivo à inovação tecnológica e, em particular, do Estado de São Paulo, que, além de representar os maiores gastos em P\&D no país, possui políticas específicas, como é o caso dos Parques Tecnológicos. O objetivo central é evidenciar que 
há políticas diferenciadas e gastos discrepantes, o que corrobora com a necessidade de melhoria dos financiamentos em outras regiões do país, para criar um sistema que seja realmente nacional de inovação.

Um dos principais dados que caracterizam a inovação tecnológica de um país é o dispêndio em P\&D em relação ao PIB e como esse dispêndio é composto, ou seja, quem executa os gastos, se setor privado ou a esfera pública. Conforme observado na Tabela 2, no ano de 2008 os gastos com P\&D no Brasil não passaram de $1,11 \%$ do PIB, índice muito abaixo das previsões brasileiras, mediante às políticas lançadas desde 2003. Segundo Cruz (2010:76), com base no discurso feito, pelo então presidente Lula, no encontro do Conselho Nacional de Ciência e Tecnologia, em 11 de setembro de 2003, o governo brasileiro, à época, esperava que essa porcentagem atingisse pelo menos $2 \%$ do PIB nesse curto espaço de tempo. Porém, o que se verificou foi um incremento de apenas 0,15\%, entre 2003 e 2008, segundo dados disponibilizados pelo $\mathrm{MCT}^{103}$ em 2010.

O Estado de São Paulo, por sua vez, no ano de 2008, apresentou um montante relativo ao seu PIB superior ao federal, pois seus gastos em P\&D foram de aproximadamente $1,52 \%$ do PIB estadual, cifra ainda maior que a de países como Espanha, Portugal, Itália, Irlanda, China e Índia; mas inferior aos gastos do Canadá, Taiwan e França e, de maneira geral, substancialmente inferior à média dos gastos da OCDE, de cerca de 2,3\% do PIB regional, (FAPESP, 2010).

Em relação à composição dos gastos, público ou privado, a diferença também foi significativa, afinal, conforme a Tabela 16, o Estado de São Paulo teve participação privada em torno de $62,8 \%$ do total dos gastos em P\&D, enquanto o Brasil, de apenas 47,7\%. O que, por sua vez, evidencia a, ainda, dependência brasileira da esfera governamental para execução dos gastos em P\&D.

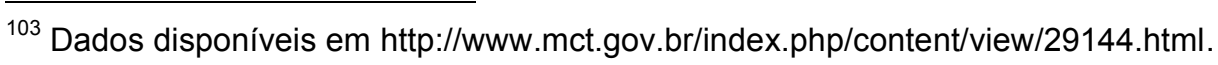


Tabela 16 - Dispêndio em P\&D no Brasil e em São Paulo. Gasto

Total (Bilhões R\$), Gasto Total (\%) e Gastos no PIB Brasileiro

(\%) - 2008

\begin{tabular}{lccc|ccc}
\hline \multirow{1}{*}{ Setores } & \multicolumn{4}{c|}{ Brasil } & \multicolumn{3}{c}{ Estado do São Paulo } \\
\cline { 2 - 7 } & Total & \%Total & \%PIB & Total & \%Total & \%PIB \\
\hline Dispêndios públicos & 17,68 & 52,33 & 0,58 & 5,74 & 37,2 & 0,19 \\
Dispêndios federais & 12,07 & 35,72 & 0,40 & 2,03 & 13,10 & 0,07 \\
Dispêndios estaduais & 5,61 & 16,61 & 0,19 & 3,73 & 24,04 & 0,12 \\
$\begin{array}{l}\text { Dispêndios } \\
\text { empresariais }\end{array}$ & 16,19 & 47,67 & 0,53 & 9,76 & 62,8 & 0,32 \\
Total & 33,8 & 100 & 1,11 & 15,54 & 100 & 0,51 \\
\hline Fonte: MCT/SEXEC/CGIN (2010); FAPESP (2010) & & & &
\end{tabular}

Ainda no que diz respeito à Tabela 16, podemos verificar o peso do Estado de São Paulo nos dispêndios brasileiros relativos ao P\&D. O estado representa, sozinho, nos gastos totais em relação ao PIB brasileiro, cerca de $0,51 \%$ dos $1,11 \%$, equivalendo a quase $46 \%$ do total despendido em 2008 em P\&D no Brasil. Um número que revela a extrema concentração das atividades relacionadas ao desenvolvimento tecnológico em um único estado dos vinte e sete da federação. Apenas os dispêndios empresariais paulistas representam cerca de $0,32 \%$ do total dos gastos no país. Esses fatos apontam para a necessidade de aprofundar as questões ligadas às políticas de inovação no estado, assim como uma análise do setor produtivo, sobretudo o ligado às atividades relacionadas à saúde. Quanto ao primeiro aprofundamento, no próximo item realizaremos uma estruturação das ações do governo estadual no que tange às políticas de CT\&I e alguns possíveis desdobramentos.

Retornando aos aspectos ligados aos gastos para inovação tecnológica no Brasil, as Tabelas 17 e 18 revelam a evolução dos gastos em P\&D no Brasil. Fica claro que, desde 2000, os dispêndios com P\&D cresceram, em números absolutos, consideravelmente, passando de $\mathrm{R} \$ 12$ bilhões para mais de $\mathrm{R} \$ 37$ bilhões, sem que tenha sido verificado em nenhum momento decréscimo do valor investido. Os valores significam um crescimento absoluto de mais de $300 \%$ nos dispêndios, no Brasil. Porém, quando observada a proporção dos gastos em relação ao PIB, além de um decréscimo verificado de 2001 até 2004, 
aquela meta proposta pelo governo federal, de atingir $2 \%$ dos gastos, não chegou nem mesmo à metade.

\begin{tabular}{|c|c|c|c|c|c|c|c|c|c|c|}
\hline \multirow{2}{*}{ Setores } & \multicolumn{10}{|c|}{ Valor em milhões de $\mathrm{R} \$$ correntes } \\
\hline & 2000 & 2001 & 2002 & 2003 & 2004 & 2005 & 2006 & 2007 & 2008 & 2009 \\
\hline Total & 12,010 & 13,580 & 14,552 & 16,284 & 17,464 & 20,857 & 23,885 & 29,145 & 33,788 & 37,798 \\
\hline $\begin{array}{l}\text { Dispêndios } \\
\text { públicos }\end{array}$ & 6,494 & 7,448 & 7,761 & 8,826 & 9,335 & 10,371 & 11,911 & 15,185 & 17,681 & 19,498 \\
\hline $\begin{array}{l}\text { Dispêndios } \\
\text { federais }^{(1)}\end{array}$ & 4,008 & 4,563 & 4,828 & 5,802 & 6,418 & 7,085 & 8,483 & 10,445 & 12,069 & 13,462 \\
\hline $\begin{array}{l}\text { Dispêndios } \\
\text { estaduais }^{(2)}\end{array}$ & 2,486 & 2,884 & 2,933 & 3,024 & 2,917 & 3,286 & 3,428 & 4,740 & 5,612 & 6,036 \\
\hline $\begin{array}{l}\text { Dispêndios } \\
\text { empresariais }\end{array}$ & 5,516 & 6,132 & 6,792 & 7,458 & 8,129 & 10,485 & 11,974 & 13,961 & 16,108 & 18,299 \\
\hline
\end{tabular}

Tabela 18 - Brasil: Dispêndio nacional em pesquisa e desenvolvimento (P\&D) por setores, em relação ao produto interno bruto (PIB), 2000-2009

\begin{tabular}{l|c|c|c|c|c|c|c|c|c|c}
\hline \multirow{2}{*}{ Setores } & \multicolumn{10}{c}{ \% em relação ao PIB } \\
\cline { 2 - 11 } & 2000 & 2001 & 2002 & 2003 & 2004 & 2005 & 2006 & 2007 & 2008 & 2009 \\
\hline Total & 1.02 & 1.04 & 0.98 & 0.96 & 0.90 & 0.97 & 1.01 & 1.10 & 1.11 & 1.19 \\
\hline Dispêndios públicos & 0.55 & 0.57 & 0.53 & 0.52 & 0.48 & 0.48 & 0.50 & 0.57 & 0.58 & 0.61 \\
\hline Dispêndios federais $^{(1)}$ & 0.34 & 0.35 & 0.33 & 0.34 & 0.33 & 0.33 & 0.36 & 0.39 & 0.40 & 0.42 \\
\hline $\begin{array}{l}\text { Dispêndios } \\
\text { estaduais }\end{array}$ & 0.21 & 0.22 & 0.20 & 0.18 & 0.15 & 0.15 & 0.14 & 0.18 & 0.19 & 0.19 \\
\hline $\begin{array}{l}\text { Dispêndios } \\
\text { empresariais }\end{array}$ & 0.47 & 0.47 & 0.46 & 0.44 & 0.42 & 0.49 & 0.51 & 0.52 & 0.53 & 0.58 \\
\hline Fonte: MCT/SEXEC/CGIN (2010)
\end{tabular}

O que chama a atenção é o fato de, a partir de 2003, o governo federal ter lançado e consolidado políticas industriais e tecnológicas, como evidenciamos nos itens anteriores, com o aumento considerável das linhas de financiamento (crédito e não reembolsável) para setores considerados estratégicos, o que ainda assim parece ser insuficiente para o desenvolvimento de um sistema nacional de inovação eficiente. No que tange à saúde, praticamente todas as políticas com viés voltado ao desenvolvimento tecnológico tiveram setores produtivos ligados à saúde contemplados. 
Fica evidente que houve uma diversificação dos investimentos e um aumento da capacidade de financiamento à inovação, ainda que o tempo de execução tenha sido relativamente reduzido, fato que indica a necessidade de manter análises e acompanhamentos constantes em relação ao tema da inovação. De qualquer forma, o quadro serve apenas de exemplificação de um panorama que vem sendo constituído no Brasil, com a consolidação dessas linhas, a despeito de seus reais efeitos na economia brasileira. Uma ressalva que se faz necessária é o crescente aumento do déficit da balança comercial brasileira dos produtos de alta intensidade tecnológica, sendo que as atividades ligadas à saúde vêm incrementando consideravelmente a pauta de importação no Brasil (Gráficos 8 e 9 e Tabelas 19 e 20). 


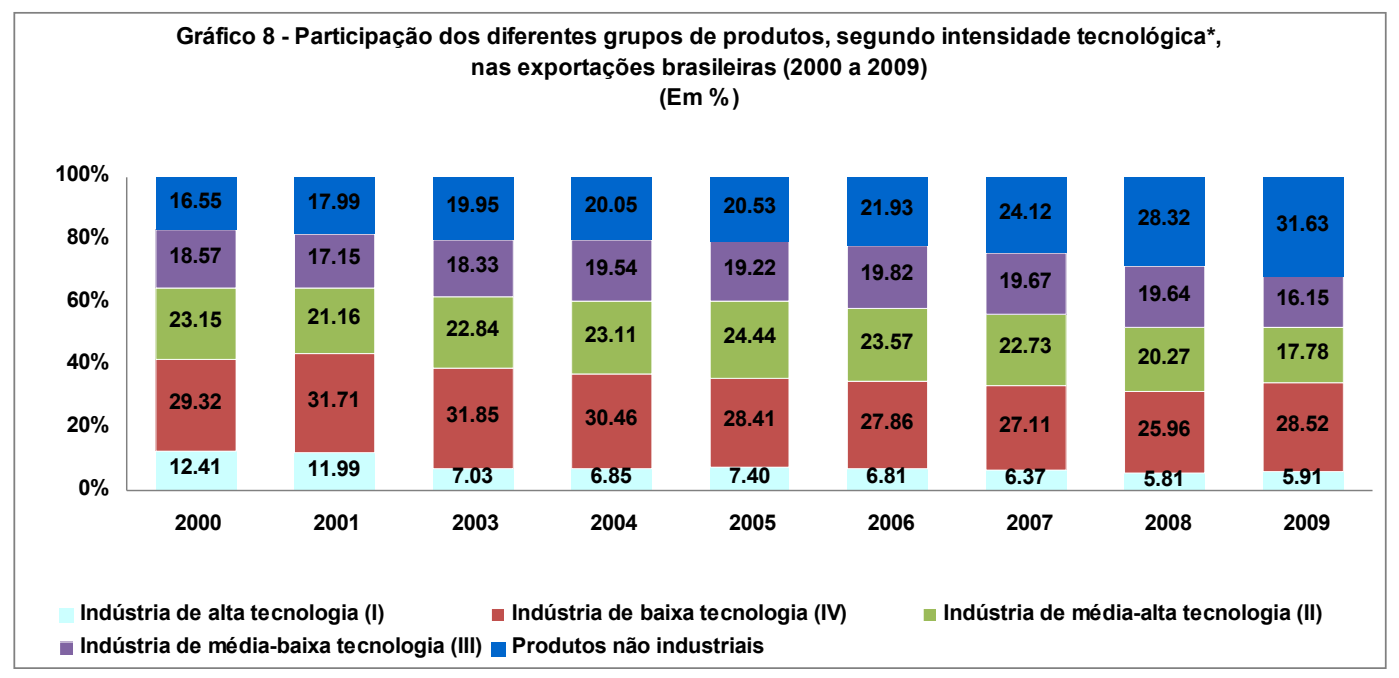

$\left(^{*}\right)$ Classificação extraída de: OECD, Directorate for Science, Technology and Industry, STAN Indicators, 2003.

Fonte: SECEX/MDIC

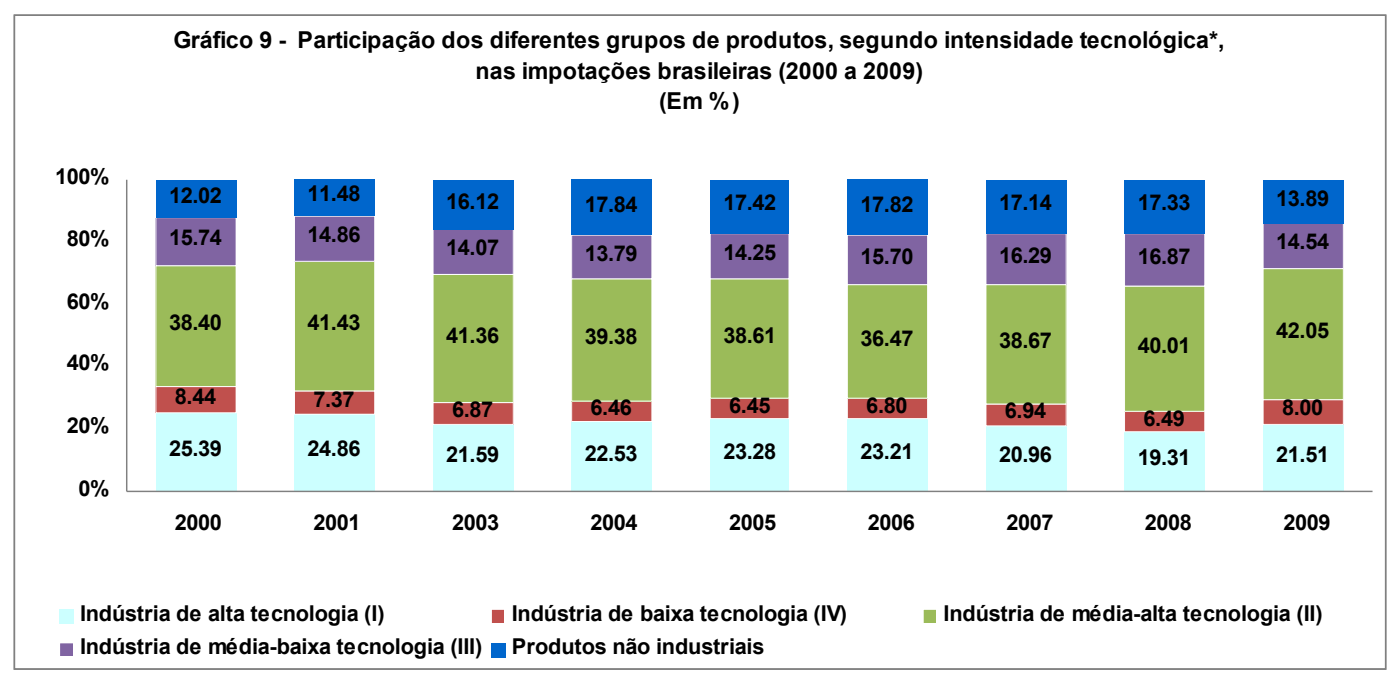

(*) Classificação extraída de: OECD, Directorate for Science, Technology and Industry, STAN Indicators, 2003.

Fonte: SECEX/MDIC 
Tabela 19 - Exportação Brasileira dos Setores Industriais por Intensidade Tecnológica (*)

2000 a 2009 - US\$ milhões FOB

\begin{tabular}{|c|c|c|c|c|c|c|c|c|c|c|c|c|c|c|c|c|c|c|c|c|}
\hline \multirow{2}{*}{ Setores } & \multicolumn{2}{|c|}{2000} & \multicolumn{2}{|c|}{2001} & \multicolumn{2}{|c|}{2002} & \multicolumn{2}{|c|}{2003} & \multicolumn{2}{|c|}{2004} & \multicolumn{2}{|c|}{2005} & \multicolumn{2}{|c|}{2006} & \multicolumn{2}{|c|}{2007} & \multicolumn{2}{|c|}{2008} & \multicolumn{2}{|c|}{2009} \\
\hline & Valor & Part. \% & Valor & Part. \% | & Valor & Part. \% & Valor & Part. \% & Valor & Part. \% & Valor & Part. \% & Valor & Part. \% & Valor & Part. \% & Valor & Part. \% & Valor & Part. \% \\
\hline Total & 55,086 & 100.0 & 58,223 & 100.0 & 60,362 & 100.0 & 73,084 & 100.0 & 96,475 & 100.0 & 118,308 & 100.0 & 137,470 & 100.0 & 160,649 & 100.0 & 197,942 & 100.0 & 152,995 & 100.0 \\
\hline Produtos industriais $(*)$ & 45,968 & 83.4 & 47,748 & 82.0 & 48,652 & 80.6 & 58,504 & 80.1 & 77,137 & 80.0 & 94,016 & 79.5 & 107,320 & 78.1 & 121,908 & 75.9 & 141,890 & 71.7 & 104,608 & 68.4 \\
\hline Industria de alta e média-alta tecnologia (I+II) & 19,589 & 35.6 & 19,300 & 33.1 & 18,870 & 31.3 & 21,829 & 29.9 & 28,905 & 30.0 & 37,669 & 31.8 & 41,768 & 30.4 & 46,760 & 29.1 & 51,630 & 26.1 & 36,254 & 23.7 \\
\hline Indústria de alta tecnologia (I) & 6,838 & 12.4 & 6,982 & 12.0 & 5,935 & 9.8 & 5,135 & 7.0 & 6,610 & 6.9 & 8,757 & 7.4 & 9,364 & 6.8 & 10,241 & 6.4 & 11,507 & 5.8 & 9,048 & 5.9 \\
\hline Aeronáutica e aeroespacial & 3,681 & 6.7 & 3,709 & 6.4 & 2,835 & 4.7 & 2,107 & 2.9 & 3,478 & 3.6 & 3,699 & 3.1 & 3,741 & 2.7 & 5,204 & 3.2 & 6,064 & 3.1 & 4,536 & 3.0 \\
\hline Farmacêutica & 403 & 0.7 & 425 & 0.7 & 440 & 0.7 & 476 & 0.7 & 590 & 0.6 & 725 & 0.6 & 905 & 0.7 & 1,134 & 0.7 & 1,482 & 0.7 & 1,550 & 1.0 \\
\hline Material de escritório e informática & 490 & 0.9 & 395 & 0.7 & 236 & 0.4 & 271 & 0.4 & 334 & 0.3 & 478 & 0.4 & 496 & 0.4 & 273 & 0.2 & 235 & 0.1 & 203 & 0.1 \\
\hline Equipamentos de rádio, TV e comunicação & 1,904 & 3.5 & 2,075 & 3.6 & 2,079 & 3.4 & 1,949 & 2.7 & 1,789 & 1.9 & 3,332 & 2.8 & 3,579 & 2.6 & 2,863 & 1.8 & 2,871 & 1.5 & 2,045 & 1.3 \\
\hline Instrumentos médicos de ótica e precisão & 361 & 0.7 & 379 & 0.7 & 345 & 0.6 & 332 & 0.5 & 421 & 0.4 & 523 & 0.4 & 643 & 0.5 & 767 & 0.5 & 854 & 0.4 & 714 & 0.5 \\
\hline & & & & & & & & & & & & & & & & & & & & 0.0 \\
\hline $\begin{array}{l}\text { Indústria de média-alta tecnologia (II) } \\
\text { Máquinas e equipamentos elétricos n e }\end{array}$ & 12,751 & 23.1 & 12,317 & 21.2 & 12,935 & 21.4 & 16,694 & 22.8 & 22,295 & 23.1 & 28,912 & 24.4 & 32,403 & 23.6 & 36,519 & 22.7 & 40,123 & 20.3 & 27,206 & 17.8 \\
\hline $\begin{array}{l}\text { Máquinas e equipamentos elétricos } n \text {. e. } \\
\text { Veículos automotores, reboques e semi-re }\end{array}$ & $\begin{array}{r}928 \\
5,349\end{array}$ & $\begin{array}{l}1.7 \\
9.7\end{array}$ & $\begin{array}{l}1,011 \\
5,360\end{array}$ & $\begin{array}{l}1.7 \\
9.2\end{array}$ & $\begin{array}{r}936 \\
5,530\end{array}$ & $\begin{array}{l}1.6 \\
9.2\end{array}$ & $\begin{array}{l}1,113 \\
7,262\end{array}$ & $\begin{array}{l}1.5 \\
9.9\end{array}$ & $\begin{array}{l}1,418 \\
9,634\end{array}$ & $\begin{array}{c}1.5 \\
10.0\end{array}$ & $\begin{array}{r}1,953 \\
12,992\end{array}$ & $\frac{1.7}{11.0}$ & $\begin{array}{r}2,618 \\
14,371\end{array}$ & $\begin{array}{r}1.9 \\
10.5\end{array}$ & $\begin{array}{r}3,200 \\
15,009\end{array}$ & $\begin{array}{l}2.0 \\
9.3\end{array}$ & $\begin{array}{r}3,777 \\
16,293\end{array}$ & $\begin{array}{l}1.9 \\
8.2\end{array}$ & $\begin{array}{l}2,997 \\
9,351\end{array}$ & $\begin{array}{l}2.0 \\
6.1\end{array}$ \\
\hline Produt & 3,331 & 6.0 & 2,851 & 4.9 & 3,147 & 5.2 & 3,930 & 5.4 & 4,817 & & 5,984 & 5.1 & 6,800 & 4.9 & 8,181 & 5.1 & 8,772 & 4.4 & 7,536 & \\
\hline Equipamentos pa & e. 117 & 0.2 & 124 & 0.2 & 130 & 0.2 & 199 & 0.3 & 289 & 3 & 560 & 0.5 & 532 & 0.4 & 578 & 0.4 & 496 & 0.3 & 346 & 0.2 \\
\hline Máquinas e equipamentos mecânicos n. e. & 3,026 & 5.5 & 2,972 & 5.1 & 3,193 & 5.3 & 4,190 & 5.7 & 6,136 & 6.4 & 7,424 & 6.3 & 8,082 & 5.9 & 9,550 & 5.9 & 10,785 & 5.4 & 6,976 & 4.6 \\
\hline nologia (III) & 10,227 & 18.6 & 9,985 & 17.1 & 10,650 & 17.6 & 13,394 & 18.3 & 18,847 & 19.5 & 22,741 & 19.2 & 27,252 & 19.8 & 31,599 & 9.7 & 38,870 & 19.6 & 24,715 & 16.2 \\
\hline Cons & 7 & 0.0 & 38 & 0.1 & 9 & 0.0 & & 0.0 & & & 194 & 0 & 30 & 0 & 724 & .5 & 1,541 & 0.8 & 119 & 0 \\
\hline Bo & 955 & 1.7 & 941 & 1.6 & 922 & 1.5 & 1,169 & 1.6 & 1,398 & & 1,709 & 1 & 2,050 & 1 & 2,569 & 1.6 & 2,870 & 1.4 & 2,320 & 1.5 \\
\hline Produto & 1,713 & 3.1 & 2,408 & 4.1 & 2,176 & 3.6 & & 3.8 & 3,203 & & 4,914 & & 6,109 & 4 & 7,136 & & 9,489 & 4.8 & 5,791 & 3.8 \\
\hline Outrc & 852 & 1.5 & 814 & 1.4 & 937 & 1. & 1,129 & 1.5 & 1,502 & 1 & 1,775 & 1.5 & 2,114 & 1. & 2,288 & 4 & 2,080 & 1.1 & 1.522 & 1 \\
\hline Produtos metálicos & 6,699 & 12.2 & 5,784 & 9.9 & 6,605 & 10.9 & 8,307 & 11.4 & 11,479 & 11.9 & 14,149 & 12.0 & 16,949 & 12.3 & 18,882 & 11.8 & 22,891 & 11.6 & 14,963 & 9.8 \\
\hline Indústria de & 16,152 & 29.3 & 18,464 & 31.7 & 19,132 & 31.7 & 23,281 & 31.9 & 29,384 & 30.5 & 33,606 & 28.4 & 38,300 & 27.9 & 43,549 & 27.1 & 51,389 & 26.0 & 43,639 & 28.5 \\
\hline & 884 & 1.6 & & 1.6 & & 1. & & 1. & & & & & 1,558 & 1. & & 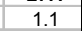 & & & 1,326 & 0.9 \\
\hline & 4,040 & 7. & & 6 & 3,837 & 6 & 4,960 & 6. & 03 & 6 & 6,503 & 5 & 232 & 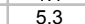 & & & & 4 & 6722 & 4.4 \\
\hline Aliment & 7,685 & 14.0 & 10,149 & 17.4 & 10,830 & 17.9 & 13,188 & 18.0 & 17,141 & 17.8 & 20,492 & 17.3 & 23,967 & 17.4 & 27,667 & 17.2 & 35,373 & 17.9 & 31,737 & 20.7 \\
\hline Têxteis, couro e calçados & 3,543 & 6.4 & 3,708 & 6.4 & 3,555 & 5.9 & 4,094 & 5.6 & 4,819 & 5.0 & 5,095 & 4.3 & 5,542 & 4.0 & 6,039 & 3.8 & 5,607 & 2.8 & 3,854 & 2.5 \\
\hline Produtos não industriais & 9,118 & 16.6 & 10,474 & 18.0 & 11,709 & 19.4 & 14,580 & 19.9 & 19,339 & 20.0 & 24,292 & 20.5 & 30,150 & 21.9 & 38,741 & 24.1 & 56,053 & 28.3 & 48,387 & $\begin{array}{r}0.0 \\
31.6\end{array}$ \\
\hline
\end{tabular}

(*) Classificação extraída de: OECD, Directorate for Science, Technology and Industry, STAN Indicators, 2003.

Obs.: n. e. = não especificados nem compreendidos em outra categoria

Fonte: SECEXIMDIC 
Tabela 20 - Importação Brasileira dos Setores Industriais por Intensidade Tecnológica (*) 2000 a 2009 - US\$ milhões FOB

\begin{tabular}{|c|c|c|c|c|c|c|c|c|c|c|c|c|c|c|c|c|c|c|c|c|}
\hline \multirow{2}{*}{ Setores } & \multicolumn{2}{|c|}{2000} & \multicolumn{2}{|c|}{2001} & \multicolumn{2}{|c|}{2002} & \multicolumn{2}{|c|}{2003} & \multicolumn{2}{|c|}{2004} & \multicolumn{2}{|c|}{2005} & \multicolumn{2}{|c|}{2006} & \multicolumn{2}{|c|}{2007} & \multicolumn{2}{|c|}{2008} & \multicolumn{2}{|c|}{2009} \\
\hline & Valor & Part. \% & Valor & Part. \% & Valor & Part. \% & Valor & Part. \% & Valor & Part. \% & Valor & Part. \% & Valor & Part. \% & Valor & Part. \% & Valor & Part. \% & Valor & Part. \% \\
\hline Total & 55,851 & 100.0 & 55,602 & 100.0 & 47,243 & 100.0 & 48,326 & 100.0 & 62,836 & 100.0 & 73,600 & 100.0 & 91,349 & 100.0 & 120,621 & 100.0 & 173,196 & 100.0 & 127,722 & 100.0 \\
\hline Produtos industriais $\left({ }^{*}\right)$ & 49,136 & 88.0 & 49,219 & 88.5 & 40,652 & 86.0 & 40,537 & 83.9 & 51,626 & 82.2 & 60,781 & 82.6 & 75,069 & 82.2 & 99,950 & 82.9 & 143,184 & 82.7 & 109,976 & 86.1 \\
\hline Industria de alta e média-alta tecnologia (I+II) & 35,627 & 63.8 & 36,860 & 66.3 & 30,330 & 64.2 & 30,418 & 62.9 & 38,901 & 61.9 & 45,552 & 61.9 & 54,514 & 59.7 & 71,929 & 59.6 & 102,731 & 59.3 & 81,189 & 63.6 \\
\hline Indústria de alta tecnologia (I) & 14,180 & 25.4 & 13,824 & 24.9 & 10,460 & 22.1 & 10,431 & 21.6 & 14,158 & 22.5 & 17,134 & 23.3 & 21,203 & 23.2 & 25,284 & 21.0 & 33,439 & 19.3 & 27,479 & 21.5 \\
\hline Aeronáutica e aeroespacial & 1,841 & 3.3 & 1,766 & 3.2 & 1,227 & 2.6 & 1,117 & 2.3 & 1,722 & 2.7 & 1,954 & 2.7 & 2,415 & 2.6 & 3,420 & 2.8 & 4,950 & 2.9 & 4,135 & 3.2 \\
\hline Farmacêutica & 2,381 & 4.3 & 2,557 & 4.6 & 2,328 & 4.9 & 2,257 & 4.7 & 2,683 & 4.3 & 3,005 & 4.1 & 3,623 & 4.0 & 4,898 & 4 & 6,124 & 3.5 & 6,116 & 4.8 \\
\hline Material de escritório e informática & 1,962 & 3.5 & 1,828 & 3.3 & 1,405 & 3.0 & 1,321 & 2.7 & 1,566 & 2.5 & 2,027 & 2.8 & 2,719 & 3.0 & 2,656 & 2.2 & 3,340 & 1.9 & 2,938 & 2.3 \\
\hline Equipamentos de rádio, TV e comunicação & 6,072 & 10.9 & 5,367 & 9.7 & 3,533 & 7.5 & 3,859 & 8.0 & 5,757 & 9.2 & 7,216 & 9.8 & 8,874 & 9.7 & 9,492 & 7.9 & 12,657 & 7.3 & 9,101 & 7.1 \\
\hline Instrumentos médicos de ótica e precisão & 1,924 & 3.4 & 2,306 & 4.1 & 1,967 & 4.2 & 1,877 & 3.9 & 2,430 & 3.9 & 2,932 & 4.0 & 3,573 & 3.9 & 4,819 & 4.0 & 6,367 & 3.7 & 5,189 & 4.1 \\
\hline & & & & & & & & & & & & & & & & & & & & 0.0 \\
\hline Indústria de média-alta tecnologia (II) & 21,446 & 38.4 & 23,036 & 41.4 & 19,870 & 42.1 & 19,987 & 41.4 & 24,743 & 39.4 & 28,418 & 38.6 & 33,311 & 36.5 & 46,645 & 38.7 & 69,292 & 40.0 & 53,710 & 42.1 \\
\hline Máquinas e equipamentos elétricos $\mathrm{n}$. e. & 2,743 & 4.9 & 3,833 & 6.9 & 3,098 & 6.6 & 2,657 & 5.5 & 2,657 & 4.2 & 2,897 & 3.9 & 3,526 & 3.9 & 4,466 & 3.7 & 6,116 & 3.5 & 5,363 & 4.2 \\
\hline Veiculos automotores, reboques e semi-reboques & 4,377 & 7.8 & 4,368 & 7.9 & 3,230 & 6.8 & 3,136 & 6.5 & 3,940 & 6.3 & 5,167 & 7.0 & 6,535 & 7.2 & 9,273 & 7.7 & 14,091 & 8.1 & 12,266 & 9.6 \\
\hline Produtos quimicos,excl. farmacêuticos & 8,189 & 14.7 & 8,074 & 14.5 & 7,634 & 16.2 & 8,625 & 17.8 & 11,641 & 18.5 & 12,149 & 16.5 & 13,596 & 14.9 & 19,033 & 15.8 & 28,881 & 16.7 & 20,035 & 15.7 \\
\hline Equipamentos para ferrovia e material de transporte $n$. & 254 & 0.5 & 228 & 0.4 & 206 & 0.4 & 151 & 0.3 & 290 & 0.5 & 429 & 0.6 & 559 & 0.6 & 644 & 0.5 & 1,262 & 0.7 & 702 & 0.5 \\
\hline Máquinas e equipamentos mecânicos n. e. & 5,884 & 10.5 & 6,534 & 11.8 & 5,702 & 12.1 & 5,419 & 11.2 & 6,214 & 9.9 & 7,775 & 10.6 & 9,096 & 10.0 & 13,229 & 11.0 & 18,942 & 10.9 & 15,343 & 12.0 \\
\hline & & & & & & & & & & & & & & & & & & & & 0.0 \\
\hline $\begin{array}{l}\text { Indústrtia de média-baixa tecnologia (III) } \\
\text { Constrãã e rearacăo aval }\end{array}$ & 8,793 & 15.7 & 8,260 & 14.9 & 6,671 & 14.1 & 6,800 & 14.1 & 8,665 & 13.8 & 10,484 & 14.2 & 14,339 & 15.7 & $\begin{aligned} 19,649 \\
55\end{aligned}$ & 16.3 & 29,221 & 16.9 & 18,571 & 14.5 \\
\hline $\begin{array}{l}\text { Construção e reparação naval } \\
\text { Borracha e produtos plásticos }\end{array}$ & $\begin{array}{r}14 \\
1297\end{array}$ & 2.3 & 1,287 & $\begin{array}{l}0.1 \\
2.3\end{array}$ & 1,219 & $\frac{0.1}{2.6}$ & $\begin{array}{r}1125 \\
1.267\end{array}$ & $\frac{0.2}{26}$ & $\begin{array}{r}14 \\
1574\end{array}$ & 2.5 & $\begin{array}{r}22 \\
1.929\end{array}$ & 26 & 2219 & 24 & 2887 & 0.0 & $\begin{array}{r}72 \\
4013\end{array}$ & 0.0 & $\begin{array}{r}259 \\
3302\end{array}$ & 0.2 \\
\hline Produtos de petróleo refinado e outros combustiveis & 4,463 & 8.0 & 3,754 & 6.8 & 2,744 & 5.8 & 2,580 & 5.3 & 3,202 & 5.1 & 3,687 & 5.0 & 5,265 & 5.8 & 7,254 & 6.0 & $\begin{array}{r}4,013 \\
12,196\end{array}$ & 7.0 & 5,841 & 4.6 \\
\hline Outros produtos minerais não-metálicos & 419 & 0.7 & 421 & 0.8 & 370 & 0.8 & 414 & 0.9 & 513 & 0.8 & 581 & 0.8 & 649 & 0.7 & 874 & 0.7 & 1,210 & 0.7 & 981 & 0.8 \\
\hline Produtos metálicos & 2,601 & 4.7 & 2,762 & 5.0 & 2,282 & 4.8 & 2,424 & 5.0 & 3,361 & 5.3 & 4,265 & 5.8 & 6,181 & 6.8 & 8,579 & 7.1 & 11,731 & 6.8 & 8,187 & 6.4 \\
\hline & & & & & & & & & & & & & & & & & & & & 0 \\
\hline Indústria de baixa tecnologia (IV) & 4,716 & 8.4 & 4,099 & 7.4 & 3,651 & 7.7 & 3,319 & 6.9 & 4,060 & 6.5 & 4,744 & 6.4 & 6,216 & 6.8 & 8,372 & 6.9 & 11,232 & 6.5 & 10,216 & 8.0 \\
\hline Produtos manufaturados n.e. e bens reciclados & 414 & 0.7 & 391 & 0.7 & 332 & 0.7 & 291 & 0.6 & 393 & 0.6 & 467 & 0.6 & 625 & 0.7 & 940 & 0.8 & 1,291 & 0.7 & 1,110 & 0.9 \\
\hline Madeira e seus produtos, papel e celulose & 1,281 & 2.3 & 1,043 & 1.9 & 869 & 1.8 & 727 & 1.5 & 941 & 1.5 & 1,089 & 1.5 & 1,396 & 1.5 & 1,638 & 1.4 & 2,079 & 1.2 & 1,629 & 1.3 \\
\hline Alimentos, bebidas e tabaco & 1,950 & 3.5 & 1,620 & 2.9 & 1,605 & 3.4 & 1,489 & 3.1 & 1,667 & 2.7 & 1,816 & 2.5 & 2,281 & 2.5 & 3,020 & 2.5 & 4,080 & 2.4 & 3,984 & 3.1 \\
\hline Têxteis, couro e calçados & 1,072 & 1.9 & 1,045 & 1.9 & 845 & 1.8 & 812 & 1.7 & 1,059 & 1.7 & 1,373 & 1.9 & 1,913 & 2.1 & 2,774 & 2.3 & 3,782 & 2.2 & 3,493 & 2.7 \\
\hline Produtos não industriais & 6,714 & 12.0 & 6,383 & 11.5 & 6,590 & 14.0 & 7,789 & 16.1 & 11,210 & 17.8 & 12,819 & 17.4 & 16,281 & 17.8 & 20,671 & 17.1 & 30,012 & 17.3 & 17,746 & $\begin{array}{c}0.0 \\
13.9\end{array}$ \\
\hline & & & & & & & & & & & & & & & & & & & & \\
\hline
\end{tabular}

(*) Classificação extraída de: OECD, Directorate for Science, Technology and Industry, STAN Indicators, 2003.

Obs.: n. e. = não especificados nem compreendidos em outra categoria

Fonte: SECEXIMDIC 
Em primeiro lugar, é importante frisar que o Brasil vem se especializado cada vez mais na exportação de produtos não industriais. Esses produtos passaram de aproximadamente $16,5 \%$ do total das exportações, em 2000, para cerca de $31,6 \%$, em 2009. Já os produtos de alta intensidade tecnológica, na pauta de exportações, caíram de $12,4 \%$ para $5,9 \%$, no mesmo período. E nesses produtos a saúde tem participação fundamental.

Conforme assinalamos, a proliferação das políticas de incentivo à inovação na área da saúde, mesmo tendo tido prioridade nos últimos anos, acabaram não logrando êxito na diminuição das importações dos setores envolvidos. As Tabelas 19 e 20 deixam clara a afirmação anterior. Baseadas nos critérios definidos pela OCDE, as tabelas ilustram um quadro preocupante. Sem contar com o período de 1996 a 2000, em boa parte marcado pela paridade entre o Real e Dólar - justificando assim as importações -, os saldos anuais da balança comercial foram sempre positivos, fato creditado em grande medida pela participação crescente dos setores 'Indústria de baixa tecnologia' e 'Produtos não industrializados'. Vale ressaltar que, até o momento, apenas o setor 'Aeronáutica e Aeroespacial', dentre os de alta intensidade tecnológica, não é deficitário. Apesar de não estar diretamente relacionada a este capítulo, essa menção é importante, pois, além de revelar uma enorme dependência em produtos de alta capacidade tecnológica, será retomada nas considerações finais.

Por outro lado, o setor 'Indústria de alta intensidade tecnológica' apresentou déficits crescentes e é exatamente nele que as atividades relacionadas à saúde se encontram - 'Farmacêutica' e 'Equipamentos médicos de óptica e precisão'. O primeiro, para o período avaliado nas tabelas, aumentou em termos absolutos cerca de $384 \%$, tendo sua participação no total das exportações aumentado de $0,7 \%$ para $1 \%$, aumento pouco expressivo quando comparado às importações, que também cresceram, tanto em termos absolutos, cerca de $256 \%$, quanto em relativo, passando de $4,3 \%$ para $4,8 \%$.

Já no caso do setor 'Instrumentos médicos de ótica e precisão', em termos absolutos, as importações cresceram ainda mais que as exportações, 
$197 \%$ e $269 \%$, respectivamente. No que se refere a participação no total das duas variáveis, as importações saltaram de $3,4 \%$ para $4,1 \%$ e as exportações sofreram retração, de $0,7 \%$ para $0,5 \%$.

A grande questão que se coloca é que essas análises têm apontado para uma ineficiência das políticas lançadas nos últimos, já que os déficits continuam crescentes. É claro que o crescimento da economia brasileira nos últimos anos serve, em boa parte, de explicação para o aumento das importações nesses setores de alta intensidade tecnológica. Porém, conforme retrataram Almeida (2009) e Capanema, Palmeira e Pieroni, (2008) essas políticas não têm surtido efeito, pelo menos no curto prazo, quanto à diminuição dos déficits e, portanto, da dependência do sistema de saúde brasileiro em relação à importação de tecnologias. O que, por sua vez, não deve ser motivo para um abandono das mesmas mas para um aprofundamento ainda maior de seus alcances e potencialidades.

\subsubsection{Políticas de inovação em saúde no Estado de São Paulo: os Parques Tecnológicos}

As políticas voltadas à inovação tecnológica no Brasil proliferaram de forma significativa nos últimos anos, tendo não só o Governo Federal incitado sua realização como também os governos estaduais e municipais. Em função da capacidade de financiamento das esferas subnacionais ser muito mais reduzida, outras formas de indução, como a criação de Parques Tecnológicos, podem ser verificadas em vários estados. Nesse sentido, o Governo do Estado de São Paulo vem desenvolvendo o Sistema Paulista de Parques Tecnológicos (SPTec) como o indutor do desenvolvimento tecnológico no estado. Por se tratar de um modelo que prevê articulação entre municípios e estado, alguns municípios passaram a fazer suas próprias políticas de inovação, tanto em consonância com o SPTec, como, também, particulares, em função de suas potencialidades. Pretendemos, portanto, analisar o SPTec, sua formação e 
desenvolvimento, e, em particular, verificar casos específicos como os de Ribeirão Preto e São José do Rio Preto, por estarem fortemente ligados ao desenvolvimento de atividades do CIS.

No ano de 2006, através do Projeto de Lei Complementar 4/2006, o Estado de São Paulo lançou uma série de medidas de incentivo à inovação tecnológica, à pesquisa científica e tecnológica, ao desenvolvimento tecnológico, à engenharia não rotineira e extensão tecnológica em ambiente produtivo. Estruturado em dez capítulos e vinte e seis artigos, o projeto procurou estabelecer: instituições fundamentais ao desenvolvimento tecnológico; estímulos à participação de ICTs, empresas, pesquisadores; a participação do Estado em fundos de investimento e as disposições sobre Parques Tecnológicos e Incubadoras de Empresas de Base Tecnológica. Portanto, a iniciativa do SPTec surge em consonância com a política estadual de inovação tecnológica, tendo sido, a partir do ano de 2006, progressivamente constituída e melhorada via outros decretos, incluindo a aprovação da Lei Complementar $n^{\circ} 1.049$, de 19 de junho de 2008, com base no projeto de lei supracitado.

Segundo Steiner (2007:4), até o ano de 2003 as iniciativas voltadas à criação de Parque Tecnológico eram articuladas entre o Governo Federal e o Estadual de maneira isolada, não tendo São Paulo uma estrutura específica para Parque Tecnológico. Nesse contexto, a Secretaria de Ciência, Tecnologia e Desenvolvimento Econômico decidiu criar "instrumentos efetivos de promoção à inovação tecnológica" (idem), financiando, junto ao PPA 20042007 da FAPESP, um projeto de estruturação dos Parques Tecnológicos ${ }^{104}$, visando "alternativas de atração de investimentos e geração de novas empresas intensivas em conhecimento ou de base tecnológica para o Estado de São Paulo" ${ }^{105}$. Em função da capacidade científica, produtiva de bens e serviços e de sua infraestrutura, a ideia foi criar um modelo de articulação entre

\footnotetext{
104 Outros projetos vinculados à estruturação dos Parques Tecnológicos são: "Formulação da Estratégia de Implantação do Sistema de parques tecnológicos do Estado de São Paulo" - Processo Fapesp n 2005/51539-0, iniciado em 1 de junho de 2005 e encerrado em 31 de maio de 2007. "Estruturação da Secretaria Técnica do Sistema Paulista de Parques Tecnológicos" - Processo Fapesp n ${ }^{\circ}$ 2006/60623-8, com encerramento em 30 de dezembro de 2007.

${ }^{105}$ Plano de Trabalho do Convênio SCTDE / FAPESP, (idem:2).
} 
prefeituras, centros de ensino e pesquisa, setor imobiliário e outros com vistas a um novo patamar de desenvolvimento para o estado.

A responsabilidade pelo desenvolvimento dos Parques ficou com a Secretaria de Desenvolvimento do Governo do Estado de São Paulo (SDE-SP). O projeto paulista de parques tecnológicos utiliza como base as proposições da IASP - Internacional Association of Science Parks. Fundamentalmente, a ideia é de criação de áreas específicas (através de empreendimentos urbanos e imobiliários) destinadas à interação entre universidade, instituições de ensino e pesquisa e empresas que promovam atração de investimentos e geração de empresas intensivas em conhecimento. Como objetivos a serem alcançados pela instalação e desenvolvimento de Parques, a IASP enfatiza cinco ${ }^{106}$, a saber:

- Criar novas oportunidades de negócio e agregar valor a empresas maduras;

- Incentivar o empreendimento e incubar empresas inovadoras;

- Gerar empregos baseados no conhecimento;

- Construir espaços atrativos para trabalhadores de conhecimentos emergentes;

- Fortalecer a sinergia entre universidades e empresas.

Para a SDE-SP, no caso específico de São Paulo, os Parques Tecnológicos devem seguir também três orientações como fatores de sucesso:

- Comprometimento das esferas federal, estadual e municipal, empresas, universidades e ICTs;

- Inserção mais ampla em programas e ações estratégicas de desenvolvimento regional e local;

- Definir segmentos específicos que tornem os Parques Tecnológicos mais competitivos, ou seja, setores em que as localidades já tenham atividades de produção e pesquisa pré-estabelecidas.

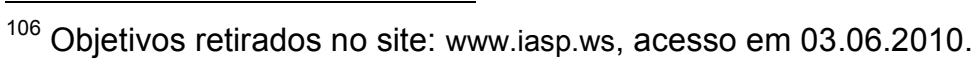


O primeiro decreto relativo a parques tecnológicos, em São Paulo, foi o Decreto $n^{\circ} 50.504$, de 6 de fevereiro de 2006. Nele foi instituído o SPTec. Em seus artigos fica clara a aproximação da constituição dos parques e as indicações da IASP, ou seja, a implantação de qualquer Parque será de acordo com "projetos urbanos imobiliários, que delimitem áreas específicas pela localização de empresas, instituições de pesquisa e serviços de apoio" (Artigo $2^{\circ}$, parágrafo único). Em função dessas prerrogativas, a implantação de um Parque não é realizada do dia para noite. O pressuposto de empreendimento imobiliário requer muitos cuidados, sobretudo quando se trata de ter garantias de atração de empresas intensivas em conhecimento, que, por sinal, é citado no artigo $2^{\circ}$ do próprio decreto. Já em relação aos tipos de atividades a serem desenvolvidas nos parques, o parágrafo IV do artigo $4^{\circ}$, estabelece a apresentação de "projeto de planejamento que defina e avalie o perfil das atividades do Parque, de acordo com os potencias científicos e tecnológicos das entidades locais e as vocações econômicas regionais" (grifo nosso). Desse ponto de vista, os Parques que terão atividades mais especificamente voltadas ao CEIS ficam basicamente restritos a Botucatu, - com base em bioprocessos para produção de medicamentos, insumos médico-hospitalares, compostos para fins industriais, fitoterápicos - Ribeirão Preto e São José do Rio Preto, pois, além de já contarem com a presença de centros de pesquisa (a exemplo das Faculdades de Medicina), também apresentam uma concentração significativa de empresas do setor de equipamentos médicos, hospitalares e odontológicos. Por fim, a participação no SPTec foi regulamentada pelo decreto $n^{\circ}$ 54.196, de 2 de abril de 2009, que estabeleceu parâmetros jurídicos às empresas que queiram fazer parte dos Parques Tecnológicos.

Ainda em relação ao arcabouço legal, o decreto $n^{\circ} 53.826$, de 16 de dezembro de 2008, definiu o conjunto de incentivos para as empresas cadastradas em Parques. Basicamente, os incentivos são dados pelos créditos acumulados de ICMS em atividades como importação, desde que sejam feitas em portos paulistas, aquisição de bens a serem utilizados em São Paulo, entre outros. No referido decreto não são instituídos fundos ou quaisquer outras formas de crédito via bancos ou fomentadoras de pesquisa do Estado. De maneira alguma isso pode ser considerado um impeditivo às políticas de 
inovação, mas vale ressaltar a diferença entre as práticas do Governo Federal e dos Governos Estaduais, especificamente o de São Paulo. No projeto de Steiner (2007), há indicativos para a utilização de incentivos e financiamentos para inovação tecnológica, a maioria federais, a exemplo das leis, dos créditos com juros abaixo do mercado para inovação tecnológica via BNDES e a própria FINEP. O autor propõe que uma aproximação desses recursos é fundamental, sobretudo pela baixa capacidade inovativa das nossas empresas, que, por terem dificuldades de financiamento, acabam preferindo estratégias de competitividade baseadas em baixo custo de produção. Além disso, é, também, comentada a importância dos incentivos municipais para inovação ${ }^{107}$, não como efetivos, afinal, poucos municípios podem utilizar de fato esse instrumento, mas como possibilidades a serem pesquisadas pelas empresas nos municípios de interesse para localização.

O uso de recursos públicos para o desenvolvimento de projetos com base inovadora tem ocorrido, principalmente, através da FAPESP, que possui linhas para empresas, como a Pesquisa Inovativa em Pequenas Empresas (PIPE), criada em 1997, ou o Programa de Apoio à Pesquisa em Empresas (PAPPE), junto ao MCT e FINEP, de 2004. Também podem ser citadas algumas alternativas isoladas, como a parceria firmada em 2006 entre a FAPESP o BNDES e a Oxiteno, indústria da área química. Neste caso específico, o convênio foi assinado para desenvolvimento de tecnologia para a produção de açúcares, álcool e derivados, somando $\mathrm{R} \$ 6$ milhões. De qualquer forma, é importante enfatizar a inexistência de fundos estaduais para inovação tecnológica, além das parcerias com a FAPESP, realizadas através de editais.

Sendo, portanto, o SPTec a principal política de inovação tecnológica de São Paulo, faremos breve atualização do andamento da política. Segundo informações da própria SDE-SP, o número de iniciativas para implantação de Parques Tecnológicos são 17, a saber: Botucatu; Campinas; São José dos

\footnotetext{
${ }^{107}$ Como exemplo, citou a cidade de São José dos Campos, que reduziu o ISS para $2 \%$ (o mínimo permitido) para atividades das cadeias produtivas dos setores aeroespacial, automotivo e telecomunicações, além dos setores de tecnologia da informação, informática e pesquisa e desenvolvimento em ciência e tecnologia, entre outros. E também, isenção no IPTU durante 2 a 6 anos para empresas novas que se instalem na cidade, em função do número de empregos e faturamento a serem gerados.
} 
Campos; São Carlos - ParTec, São Carlos -; Damha; São José do Rio Preto; Piracicaba; Sorocaba; Americana; Araçatuba; Grande ABC; Guarulhos; Santos; São Paulo - Jaguaré, São Paulo -; Zona Leste; Ribeirão Preto; e Rio Claro. Destes, apenas oito encontram-se com cadastramento provisório já realizado: Botucatu; Campinas; São José dos Campos; São Carlos - ParTec, São Carlos - Damha; São José do Rio Preto; Piracicaba e Sorocaba.

É importante notar que, apesar de três dessas propostas de constituição de Parques Tecnológicos serem voltadas para a área da saúde, a definição ainda não conta com participação efetiva da Secretaria Estadual de Saúde (SES-SP). Como já foi mencionado, o órgão responsável pelo desenvolvimento e implantação dos Parques Tecnológicos é a SDE-SP, que, por sua vez, realiza articulações com os municípios. A ressalva, no entanto, fica por conta da criação do Conselho Estadual de Ciência e Tecnologia e Inovação em Saúde, em 2008, que, até o momento, realizou apenas uma reunião para discutir a questão dos Parques Tecnológicos, mas, segundo Ricardo Oliva ${ }^{108}$, o Conselho ainda está estudando o funcionamento da política de Parques Tecnológicos para que, depois, a SES-SP possa ter uma atuação mais efetiva.

A garantia de sucesso do modelo de Parque Tecnológico, tal como concebido em São Paulo, não é perfeitamente assinalada na literatura e nem de fácil quantificação estatística. $\mathrm{Na}$ realidade, essas são questões já discutidas em algumas literaturas, sobretudo pelo fato do modelo ser 'vendido' como profícuo e garantidor de retorno econômico e desenvolvimento tecnológico. Parece óbvio que existam, também, exemplos bem sucedidos de Parques Tecnológicos, como é o caso do estudo sobre o Parque Tecnológico de Zhongguancun, em Beijin, elaborado por Tan (2006). Não pretendemos esgotar o tema, mas apenas trazer alguns comentários críticos aos Parques Tecnológicos. No estudo de Vedovello, Judice e Maculan (2006), os autores ressaltaram, principalmente, a questão de não haver dados substanciais que comprovem a existência de relação de efetividade da inovação tecnológica com a implantação de Parques Tecnológicos. Em relação aos aspectos problemáticos, os autores enfatizaram basicamente três: a) longo prazo de

${ }^{108}$ Coordenador da Coordenadoria de Ciência e Tecnologia e Insumos Estratégicos de Saúde da Secretaria Estadual de Saúde, entrevista realizada dia 27 de julho de 2009. 
desenvolvimento e maturação; b) elevado custo de implantação; c) dificuldades em conciliar múltiplos objetivos colocados nesse tipo de projeto por stakeholders variados.

No caso do estudo desenvolvido por Shearmur e Doloreux (2000), em 17 Parques Tecnológicos no Canadá, os autores argumentaram, dentre outros fatores, que esse modelo, na maior parte dos casos, além de não trazer nenhum benefício real em termos de inovação tecnológica para as localidades onde estão inseridos, muitas vezes promovem uma apropriação do conhecimento universitário por grandes empresas, o que chamaram de 'privatizar os resultados das pesquisas universitárias'.

Desse ponto de vista, parece haver um caso em São Paulo, que tem procurado fazer com que as políticas de inovação não se restrinjam, única e exclusivamente, ao modelo de Parques Tecnológicos, e sim a políticas mais amplas promovidas pela gestão municipal, em parceria com uma instituição muito peculiar criada com o intuito de fortalecer a política de inovação municipal, a Fipase. É o caso de Ribeirão Preto.

\subsubsection{Parque Tecnológico de Ribeirão Preto}

As políticas de incentivo à inovação tecnológica, no município de Ribeirão Preto, apresentam características muito particulares. Se procurarmos seu cadastramento no SPTec, até setembro de 2009 nada será encontrado, o que, em primeira instância, nos levaria à conclusão de que a cidade está atrasada em seus projetos voltados à inovação. Fato que não pode ser afirmado, sobretudo se atentarmos para a atuação da Fundação Instituto Polo Avançado de Saúde (Fipase) ${ }^{109}$, criada através da Lei Complementar $n^{0} 1.222$, de 30 de maio de 2001, alterada pela Lei Complementar $n^{\circ}$. 2291, de 24 de Julho de 2008. Sua primordial função é promover o desenvolvimento

${ }^{109}$ A Fundação é vinculada a Secretaria Municipal de Planejamento e Gestão Ambiental de Ribeirão Preto. 
socioeconômico local e regional, com base na pesquisa e na aplicação do conhecimento científico e tecnológico.

Os aportes financeiros da Fipase são aprovados em orçamento da Prefeitura Municipal de Ribeirão Preto e também captados por diferentes órgãos de fomento, como: SEBRAE, FINEP, CNPq, FAPESP e CAPES. Nessa perspectiva, a Fipase tem uma participação destacada na indução da inovação tecnológica em Ribeirão Preto, incluindo articulações com programas federais, como o PRIME da FINEP e por suas linhas prioritárias, verificadas abaixo:

a) Gestão da SUPERA - Incubadora de Empresas de Base Tecnológica: a incubadora, que iniciou suas atividades em 2003, foi resultante de um convênio entre a FIPASE, a USP, o SEBRAE-SP e a Prefeitura Municipal de Ribeirão Preto;

b) Planejamento e implantação do Parque Tecnológico de Ribeirão Preto, em parceria com a Prefeitura Municipal de Ribeirão Preto, a USP e a CEAL, com a realização de esforços para a implantação efetiva do Parque Tecnológico, ainda não cadastrado na Secretaria de Desenvolvimento do Estado de São Paulo;

c) Participação na estruturação do Arranjo Produtivo Local (APL) da indústria de Equipamentos Médicos Hospitalares e Odontológicos $(E M H O)$ de Ribeirão Preto, em parceria com a Prefeitura Municipal de Ribeirão Preto, SEBRAE, SENAI, CIESP/FIES;

d) Realização do Seminário de Rotas Tecnológicas da Biotecnologia no Brasil: evento de âmbito nacional, que reuniu, nas suas três edições em 2005, 2006 e 2007 -, cerca de 1050 pessoas, entre empresários, investidores, pesquisadores, docentes e pós-graduandos para a discussão das rotas tecnológicas da biotecnologia. O evento contou com a parceria de diversas instituições, como a Agência USP de Inovação, o SEBRAE-SP, CNPq, a FAPESP, a CAPES e empresas privadas.

A importância da Fipase pode ser verificada por seus projetos e sua atuação na articulação entre empresas, universidades, poder público e linhas 
de financiamento ${ }^{110}$. Desde sua fundação, a Fipase lançou uma série de estudos contendo orientações para o desenvolvimento do projeto do PTRP, como quais atividades poderiam ser desenvolvidas na cidade e quais instituições teriam papel central no desenvolvimento das mesmas. Em linhas gerais, as atividades a serem desenvolvidas no PTRP se concentram nas áreas de Biotecnoligia e Saúde, contemplando o setor EMHO.

Em relação à Biotecnologia, Porto e Scorzafave (2007:5) definiram, tendo como base as atividades de pesquisa e produção já existentes no município, as seguintes áreas:

- Saúde Humana: diagnóstico; fármacos; fitofármacos; vacinas e soros.

- Saúde Animal: vacinas e identificação genética.

- Agronegócio: bioenergia (cana); bioinseticidas e transgênicos.

- Industrial: bioenergia (etanol e biodiesel); vitaminas, antibióticos; enzimas e biopolímeros.

- Meio Ambiente: biorremediação; tratamento de resíduos; análise de ambientais.

No setor de fármacos, medicamentos e cosméticos, as mesmas autoras definiram como prioritárias as ações que envolvem os seguintes setores: cosméticos; desenvolvimento e avaliação de genéricos; farmoquímicos obtidos por via biotecnológica; medicamentos antinfecciosos; medicamentos de liberação sustentada; medicamentos fitoterápicos para uso humano e veterinário; soros e vacinas humanos; transformação do sangue e seus derivados. Para o setor de EMHO não foram definidas linhas especificas.

Para a análise da implantação do PTRP e de outras formas particulares de incentivos à inovação, além de documentos oficiais, utilizamos entrevistas realizadas com gestores e professores da Faculdade de Medicina de Ribeirão Preto.

\footnotetext{
${ }^{110}$ No caso específico das empresas do setor de EMHO, por exemplo, a Fipase disponibiliza uma orientação, intitulada "Guia Orientativo para o Setor Odento-Médico-Hospitalar e de Laboratórios", que foi elaborada no ano de 2008 pelo BNDES, Caixa Econômica Federal, Finep, ABIMO e ABDI.
} 
Atualmente, a prefeitura está preparando o credenciamento do PTRP junto à Secretaria de Desenvolvimento do Estado de São Paulo. O requerimento já foi feito e está sendo analisado e revisado pela Reitoria da Universidade de São Paulo. Vale ressaltar que já existe um aparato legal, da prefeitura, que procura estabelecer as normas para a criação do PTRP, dado pelo Ato $\mathrm{n}^{\circ} 153$ de 25 de junho de 2007, que "Institui a política pública municipal em ciência, tecnologia e inovação, cria o programa de apoio à criação de parques tecnológicos em Ribeirão Preto e dá outras providências".

Segundo a visão da prefeitura ${ }^{111}$, o PTRP deve articular os interesses públicos; o compromisso social e o desenvolvimento local, regional e externo. Em relação ao interesse público, foram apontadas as necessidades de cuidado com o dinheiro público e de extrapolar o sentido do PTRP para além de um empreendimento imobiliário, fazendo também o que denominou de marketing global. O PTRP está em construção e ainda não é possível avaliar seus alcances, mas só terá sentido se houver uma articulação com o setor saúde. Já em relação ao desenvolvimento local, regional e externo, foi apontada a preocupação com o fortalecimento das indústrias instaladas na cidade e com a atração de novas indústrias para Ribeirão Preto. $O$ exemplo dado foi o de que o PTRP não pode servir apenas como porta de entrada para importações de países asiáticos mas também como mecanismo de desenvolvimento das empresas locais.

Há uma busca pela articulação entre os interesses privados e públicos relacionados à questão do empreendimento imobiliário que envolve a criação do PTRP. A ideia é que o parque não só valorize áreas, com também traga retorno do ponto de vista da criação e melhoria de postos de trabalho.

O projeto do PTRP está dividido em cinco etapas. A Fase I, da criação do PTRP $^{112}$, que está sendo realizada no momento, apresenta duas prioridades em relação às áreas a serem destinadas ao parque: a parceria com a Universidade de São Paulo, inclusive na disponibilidade de áreas da própria

\footnotetext{
${ }^{111}$ Entrevista realizada junto a Secretaria de Planejamento e Gestão Ambiental, no dia 3 de agosto de 2009

112 O projeto de criação do PTRP prevê cinco fases para a sua efetiva implantação.
} 
universidade e áreas no seu entorno, atualmente utilizadas para a produção de cana-de-açúcar, mas em governos anteriores já foram feitas negociações (amparadas na legislação) com os proprietários e a Fipase. Ainda na Fase I está prevista a estruturação de um Plano de Negócios, que seria realizado através da identificação das demandas. Nesse caso, a Fipase tem atuação importante, em programas como o SUPERA, e no próprio desenvolvimento do planejamento.

A prefeitura de Ribeirão Preto tem uma estratégia muito particular em relação ao PTRP. Diferente de outros parques do estado, Ribeirão Preto não fez primeiro o credenciamento, junto à SDE, para começar a criação. O processo ocorre junto a outras iniciativas, a maioria encabeçadas pela Fipase, como o SUPERA, O APL, o PRIME (subvenção econômica com verba da FINEP). Segundo a prefeitura, há falta de articulação do estado com os municípios, no sentido de criar um espaço de discussão e conhecimento das experiências de outros parques que já existem no estado. Ou seja, a SDE apenas faz o credenciamento, mas não promove um ambiente de debates. Até na prefeitura há uma relativa desarticulação, pois, mesmo tendo muita informação sobre o processo de criação do parque, poucos gestores debatem o assunto.

Um aspecto muito particular de Ribeirão Preto é a busca, pela prefeitura, de financiamentos federais, como é o caso da parceria MCT e FINEP para o PRIME, que já está em andamento na cidade, mas ainda não foram apresentados resultados do programa.

\subsubsection{Parque Tecnológico de São José do Rio Preto}

Diferente de Ribeirão Preto, São José do Rio Preto já oficializou seu cadastramento junto à SDE-SP, sendo, inclusive, um dos pioneiros no estado. Partindo dos mesmos pressupostos conceituais de PT da SDE-SP, o município conta com importantes instituições de pesquisa, sobretudo na área da saúde, o 
que lhe confere plena capacidade de exercício e implantação de um Parque Tecnológico. O início do funcionamento dos PARQUES TECNOLÓGICOS JRP está previsto para 2010 e terá como principal estratégia estabelecer-se como um dos principais polos de inovação tecnológica de equipamentos EMHO no país. O parque pretende abrigar também atividades ligadas à biotecnologia e tecnologias da informação.

São José do Rio Preto (SP), enquanto polo de produtos e tratamentos médico cardiológicos, constitui uma referência e um bem sucedido caso de integração, no âmbito do Complexo Industrial e Econômico da Saúde (CIES), entre Empresas (indústrias de equipamentos e insumos), Instituições de Ensino e Pesquisa (públicas e privadas) e Prestadores de Serviços (Hospitais, Clínicas e Laboratórios). A pujança do setor saúde está atrelada às interfaces com um contexto econômico diversificado e à presença de instituições de ensino e formação. Um forte componente dinamizador do sistema é dado pela atuação do governo municipal, pela cultura institucional compartilhada, pela densidade comunicacional e pelo acentuado intercâmbio interinstitucional entre os atores. Há predominância de ações, programas, projetos e políticas sociais e econômicas convergentes, integradas e não setoriais, buscando abarcar todos os níveis e esferas de atividades e populações. Trata-se de uma tradição no município, que, segundo depoimento de muitos atores e instituições, se deve ao 'isolamento' da região, o que sempre reforçou a busca por soluções e arranjos locais. Contudo, assinala-se que tanto as indústrias quanto serviços e grupos de pesquisadores estabelecem parcerias, convênios e relações com circuitos produtivos e círculos de cooperação mais amplos, os quais excedem o âmbito local, apresentando conexões regionais, nacionais e mesmo internacionais. Diversas instituições (produtivas, acadêmicas e de P\&D) têm acesso ou captam editais de financiamento e linhas de crédito governamentais.

Em relação ao PARQUES TECNOLÓGICOSJRP, parece haver uma grande articulação entre instituições (Faculdade, Institutos, Incubadora, Empresas etc.). Em entrevista com a Diretora Adjunta da FAMERP ${ }^{113}$, a

\footnotetext{
${ }^{113}$ Entrevista realizada em 10 de agosto de 2009 com a Dra. Dorotéia Rossi Silva de Souza, Diretora Adjunta de Pesquisa da FAMERP (Faculdade de Medicina de São José do Rio Preto).
} 
intenção é realizar montagem de laboratórios e instalações comuns a todos os presentes no parque. A dificuldade de efetivação da implantação do parque se dá, sobretudo, pela excessiva burocracia, interesses políticos e trocas de governo (não continuidade). Porém, há pontos positivos, como a continuidade de ações, programas, planos e políticas, algo que acontece por conta da familiaridade e cumplicidade entre os diversos atores, já que todos têm papéis polivalentes ao longo da história (alternam-se em cargos e funções nas diversas instituições).

No caso das atividades de $\mathrm{TI}$, já existem parcerias com cursos de $\mathrm{TI}$, realizados pela UNESP e FATEC, que visam o desenvolvimento de softwares para diagnósticos de imagem, com grupos de pesquisadores da FAMERP.

Existe uma comissão municipal, da qual a FAMERP participa juntamente com as demais instituições de ensino e empresas de C\&T\&I da cidade, cujos objetivos são regulamentar e implantar o PARQUES TECNOLÓGICOS JRP. A FAMERP participa, juntamente com as instituições e empresas com Projetos 'Ancora' de C\&T\&I do Parque Tecnológico, que serão desenvolvidos nos Laboratórios, Centros de Pesquisa e nas Dependências do Hospital de Base. E a constituição básica do PARQUES TECNOLÓGICOS JRP se dará por: incubadora tecnológica, empresas de base tecnológica, laboratórios de metrologia e certificação, laboratórios de desenvolvimento de produtos, Centro Integrado de Ciências - CIC, arranjo produtivo local -, APL e Centro Tecnológico de Rio Preto (CTRP). Os principais parceiros são as Universidades e/ou Centros de Pesquisa: Universidade Estadual Paulista (UNESP), Faculdade de Medicina de São José do Rio Preto (FAMERP) e Faculdade de Tecnologia de Rio Preto (Fatec). Principais áreas de competência de C\&T\&I dos parceiros do Parque Tecnológico: Universidade Estadual Paulista (UNESP), com cursos de graduação e pós-graduação em Física, Química, Biologia, Matemática, Engenharia de Alimentos, Ciências da Computação, além de outros na área de humanidades; Faculdade de Medicina de São José do Rio Preto (FAMERP), com graduação em Medicina e Enfermagem e pós-graduação (Stricto Senso) em Ciências da Saúde, além de 47 cursos de pós-graduação Lato Senso; Faculdade de Tecnologia de Rio 
Preto (FATEC), com graduação em Tecnologia em Informática para a Gestão de Negócios, Tecnologia em Agronegócios e, em breve, Tecnologia em Mecânica de Precisão, além do de pós-graduação Lato Senso em Consultoria Web.

Em vista do que foi mencionado, parece haver, tanto em Ribeirão Preto, quanto em São José do Rio Preto, institucionalidades que permitem políticas subnacionais muito particulares de inovação tecnológica, mesmo estas estando em consonância com os planos federais e estaduais. Os desdobramentos no curto e médio prazo dessas políticas se configuram como elementos centrais nas análises do desenvolvimento de atividades com alto conteúdo de conhecimento, principalmente pelo caráter mais descentralizado das ações. É nesse sentido que um aprofundamento dessas políticas também configura como elementos fundamentais de análise na condução da política de CT\&I brasileira, argumentação que pretendemos retomar nas Considerações Finais deste trabalho. 
As discussões sobre inovação tecnológica ganham grande espaço nos estudos sobre desenvolvimento, competitividade e crescimento econômico e apresentam uma dimensão geográfica fundamental. Furtado (2005) procurou estabelecer uma diferenciação sobre as opções e trajetórias tecnológicas nos países desenvolvidos e subdesenvolvidos. Sua análise apontava para uma situação em que, nos países subdesenvolvidos, as opções tecnológicas estavam pautadas no paradigma energético e as trajetórias tecnológicas constituíam-se basicamente de transferência internacional de tecnologia. Essa situação, sobretudo decorrente da importação de tecnologias, nos levou a refletir sobre quais seriam as alternativas possíveis para o avanço em direção a uma maior autonomia. Nesse ponto de vista, as políticas de incentivo à inovação nos pareceram ser um importante caminho.

A ênfase, dada por Santos (1997), quanto à importância dos sistemas técnicos e dos sistemas de ações na constituição do espaço geográfico, já apontava para uma agenda de pesquisa que contemplasse uma abordagem da inovação pela Geografia, a despeito de suas reflexões sobre esse tema terem sido fortemente pautadas na crítica à teoria da Difusão das Inovações, proposta pelo geógrafo suíço Torten Hagrestand, e no fato do próprio conceito de inovação tecnológica não fazer parte estrutural de suas análises.

$\mathrm{Na}$ presente tese, procuramos resgatar esse fundamento do espaço geográfico, a indissociabilidade entre sistemas de objetos e sistemas de ação, para realizar uma análise das políticas de inovação tecnológica que têm sido criadas e desenvolvidas no Brasil, mas com o foco em uma abordagem geopolítica do tema, já que é relacionada às questões do poder e da dependência externa. Assim, a consolidação de políticas e fóruns de debates para a promoção da inovação, bem como a materialização dessas ações no território nos pareceram fundamentais para a compreensão desse complexo mosaico formado pelos interesses nacionais, como defesa, saúde, comunicações e as efetivas políticas de indução à inovação. 
Ainda que o arcabouço teórico tenha dado ênfase ao aspecto geopolítico da inovação e sua visão sistêmica, procuramos, ao longo da tese, demonstrar essa indissociabilidade entre sistemas de objetos e sistemas de ações com os exemplos dos financiamentos e das políticas nacionais como elementos de consolidação, no território nacional, de uma capacidade inovativa mais adequada a nossa realidade; afinal, o destaque para áreas estratégicas, e a saúde dentre elas, deixa isso evidente, a despeito do aumento paulatino da importação de produtos de alta intensidade tecnológica. Esse resultado negativo se mostrou mais como um reflexo de outros aspectos econômicos como a valorização do real, que, por sua vez, estimula as compras de produtos de alta intensidade tecnológica -, que não podem ser controlados por políticas específicas de inovação. O que não diminui a importância dessas políticas, muito menos sua continuidade.

Ainda em relação à questão teórica, alguns apontamentos são necessários. Em primeiro lugar, reiteramos nossa aproximação analítica com a noção de 'sistema nacional de inovação'. Essa perspectiva foi fundamental para pontuar a complexidade que envolve as políticas de inovação, já que é dada pela participação de diversos agentes e instituições e pela definição de prioridades ajustadas às necessidades de cada país.

Em segundo lugar, realizamos um esforço para pontuar os debates sobre inovação e espaço. Nesse ponto, nossa maior preocupação foi evidenciar que os estudos geográficos sobre inovação têm tido uma perspectiva mais próxima das reflexões dos fatores que levam à concentração das atividades inovativas em diferentes localidades e da questão do desenvolvimento regional. Esses estudos mostraram relevância quanto a sua aplicação a fenômenos ligados à inovação, porém nossa opção foi dar um enfoque na Geopolítica da inovação. Assim, estabelecemos um resgate histórico das teorias ligadas à Geografia Política e à Geopolítica, abrindo a possibilidade de enfoque da última pelo prisma da inovação tecnológica.

Como demonstrado no segundo capítulo, a contribuições geopolíticas às políticas imperialistas levaram à proliferação de críticas e estigmas aos estudos geopolíticos. A participação do general Haushofer na formulação das políticas 
nazistas é o maior exemplo dessas críticas. Para diversos autores, esse fato colocou a Geopolítica em desalinho com a teoria geográfica, contribuindo para que suas análises fossem cada vez mais rechaçadas em estudos acadêmicos. O que procuramos demonstrar foi como a Geopolítica representa uma importante corrente teórica, que privilegia suas análises através das políticas de Estado em defesa de temas considerados, em diferentes períodos, estratégicos para o desenvolvimento nacional. Assim foi a geopolítica do período militar no Brasil, que teve influência direta do pensamento geopolítico nacional, com Golbery do Couto e Silva, e assim pode ser retomada tendo em vistas a consolidação de políticas de inovação, porém, agora, sem o enfoque autoritário e militarista característico daquela época.

Para a consolidação dessa abordagem da inovação como elemento central da Geopolítica brasileira utilizamos uma análise de dois eixos estruturais da inovação: o primeiro dado por um financiamento que determina áreas estratégicas para o desenvolvimento nacional e diminuição da dependência externa de tecnologias; o segundo, as políticas voltadas especificamente à saúde, já que lidam com aspectos econômicos, ligados aos gastos públicos e à dependência de medicamentos e equipamentos importados, e com questões que dizem respeito ao bem-estar da população.

Em relação ao primeiro, o ineditismo da subvenção econômica no Brasil, em si, implica uma necessidade de acompanhamento de seus resultados. A falta de estudos que comprovem a eficiência dessa política indica, ainda, que temos um longo caminho para abordá-la de maneira mais contundente. Ao longo de quatro anos, esse mecanismo de indução à inovação teve abrangência considerável, tanto no que diz respeito ao número de empresas beneficiadas quanto ao volume de recursos despendidos, se considerarmos que os dispêndios são realizados exclusivamente para empresas privadas. Esse apontamento é extremamente relevante, pois, se considerados todos os Fundos Setoriais e outras formas de financiamento à inovação, seus números são relativamente baixos.

Ainda que seja muito cedo para conclusões assertivas, a política aqui discutida ressalta mudanças na condução do sistema nacional de inovação 
brasileiro e esse nos pareceu um eixo estrutural da análise. Sua dimensão, em termos das transformações institucionais e legais, promovidas no MCT, na FINEP e na legislação brasileira, é exemplo claro disso, sobretudo se observado o fato do programa constar no PPA do governo federal para os próximos anos. Porém, não se pode negar a existência de gargalos e, neste sentido, alguns apontamentos se fazem necessários.

O desenvolvimento de estratégias legais aparece como elemento fundamental para a continuidade do programa e para a geopolítica brasileira. As questões relativas às compras governamentais e um maior comprometimento das empresas contratadas se mostraram centrais para a melhoria do programa, tendo em vista, sobretudo, que o mesmo chegue cada vez mais próximo dos seus objetivos.

Dois principais requisitos da política em questão aparecem desde o primeiro edital: a necessidade de fomentar a inovação em micro e pequenas empresas e a urgência de ter um alcance territorial para além da região mais desenvolvida do país, o Sudeste. Em relação ao primeiro, efetivamente foram observadas mudanças, tendo as empresas de menor porte aumentado sua participação ao longo dos anos. Já a tentativa de desconcentrar territorialmente o financiamento, ainda que se configure como um dos objetivos centrais do programa, não foi verificada, revelando uma maior capacidade de uso do território pelas empresas localizadas nos centros mais dinâmicos do país, com forte ênfase da participação do estado de São Paulo nos desembolsos. Por outro lado, a análise do perfil das empresas não indica que as deste estado são as mais inovadoras, apesar de serem as que mais participaram do programa, o que, por sua vez, também pode ser justificado pela presença de empresas de todos os portes.

Em relação às análises do perfil das empresas, o fato da subvenção ser recente, do número de contratos ainda não ser relativamente grande e de ter havido uma mudança nos objetivos do programa - com aumento da participação de micro e pequenas empresas, nos leva à consideração de que análises como esta devem continuar sendo feitas com 0 intuito de acompanhamento constante dos resultados efetivos da subvenção. Afinal, 
houve uma irregularidade considerável no processo de contratação nos primeiros anos do programa, fato que tende a diminuir nos próximos anos.

A despeito de ser um financiamento criado e efetivado no governo Lula, não podemos, de forma alguma, atribuir seus sucessos e problemas a um ou outro governo. Nas apreciações sobre as questões normativas e institucionais, procurou-se deixar claro que a subvenção é resultado de um processo que evidencia uma política de Estado e não uma política de governo, decidida por tal ou qual partido, ainda que tenhamos tido um incremento das políticas de incentivo à inovação. Como Pacheco (2005) demonstrou, o FNDCT já vinha sendo modificado antes mesmo da transição para o governo Lula. É neste sentido que a sua condução e desenvolvimento futuro devem permanecer indiferentes de políticas partidárias.

A área da saúde, analisada como política social e econômica, foi central para compreensão de uma Geopolítica da inovação. Em princípio, analisamos a consolidação da saúde como elemento estruturante da PITCE, através da indústria farmacêutica. Os resultados indicaram que não há, até o presente momento, sinais de diminuição da dependência da importação de fármacos e medicamentos no Brasil. Esse fato corrobora a necessidade de manutenção das políticas de incentivo à inovação, para essas cadeias produtivas, que funcionam com o predomínio de grandes conglomerados multinacionais. Após essa apreciação, realizamos uma análise da entrada dos setores estratégicos produtivos, que dependem de alta capacidade tecnológica, nos programas de governo Mais Saúde e PACT\&I. Em relação ao primeiro, evidenciamos uma série de medidas para fortalecimento da produção nacional de insumos fundamentais ao sistema de saúde brasileiro. A questão da inovação foi introduzida com base no conceito de complexo industrial da saúde, prevendo investimento de mais de $\mathrm{R} \$ 84$ bilhões, o que demonstra a extrema relevância da inovação nesse setor. Já em relação ao segundo, o plano de ação situava os insumos de saúde como uma das 13 prioridades estratégicas em pesquisa, desenvolvimento e inovação. A saúde passou a ser contemplada com cinco programas, a saber: fármaco e medicamentos, produtos médicos e biomateriais, kits diagnósticos, hemoderivados e vacinas. A previsão total de recursos a ser 
despendidos era de mais de $\mathrm{R} \$ 50$ milhões, sendo, hoje, possível fazer uma avaliação desses dispêndios, já que os resultados dos editais estão disponíveis. Porém, essa análise não foi possível para este trabalho. Outra importante questão verificada no plano foi a participação de uma vasta gama de instituições para a consolidação dessa política. Podemos citar: Ministério da Saúde, Ministério do Desenvolvimento, Indústria e Comércio Exterior, Ministério do Meio Ambiente, institutos tecnológicos, como o Instituto Butantan e a FIOCRUZ, e associações empresariais. Essa institucionalidade revela uma visão da saúde como elemento estratégico por diversos órgãos, tanto governamentais quanto privados, o que demonstra a importância política dessa área.

Ainda em relação à saúde, a discussão sobre o poder de compra do Estado veio à tona, revelando ser um elemento fundamental não só das políticas de inovação de maneira geral como específicas da saúde. Esse mecanismo tem respaldos legais nos organismos internacionais de comércio e, como demonstramos, é utilizado por vários países. Porém, no período analisado, a legislação brasileira não previa prioridade para nenhum tipo de compra que fortalecesse o sistema nacional de inovação, revelando assim uma urgência na alteração dessa lei, de maneira a possibilitar a complementaridade entre as políticas de inovação e os gastos governamentais.

Por fim, analisamos a política estadual paulista de incentivo à inovação em saúde. Esse estado, como evidenciamos, representa $0,51 \%$ do total dos dispêndios em P\&D no Brasil. $\mathrm{Na}$ área da saúde, analisamos duas concentrações produtivas específicas, Ribeirão Preto e São José do Rio Preto. Os dois casos articulam a instalação de um parque tecnológico junto à já consolidada rede de pesquisa em saúde, através da Faculdade de Medicina de Ribeirão Preto, da USP, da FAMERP e de indústrias do setor EMHO. O caso de Ribeirão Preto é mais emblemático, pois ainda conta com a Fipase, uma instituição ligada à secretaria de gestão do município com o objetivo de promover o desenvolvimento sócio-econômico baseado na aplicação do conhecimento científico e tecnológico, ou seja, fica explícita uma política municipal de apoio à inovação. Procuramos, dessa forma, demonstrar que a 
saúde como área estratégica da inovação está situada além das políticas federais, consolidada na própria política de desenvolvimento do Estado de São Paulo e, no caso de Ribeirão Preto, já está sendo realizada pelo poder municipal, o que enaltece ainda mais seu caráter estratégico.

Reservamos para este momento a reflexão, que aparece no capítulo dedicado à saúde, sobre a balança comercial brasileira em relação a produtos de alta intensidade tecnológica, pelo fato dela não estar restrita apenas à área da saúde.

Apesar dos esforços empreendidos, não só pelos governos federal e estadual mas por todas as instituições e pesquisadores envolvidos com o tema da inovação tecnológica, o Brasil ainda apresenta sérios gargalos a serem resolvidos. Se houve, de um lado, a consolidação de financiamentos e políticas à inovação cada vez mais sólidos, por outro, os resultados esperados, ou seja, o aumento da capacidade inovativa, assim como a diminuição da dependência de tecnologias importadas, não têm sido observados, sobretudo quando analisamos a pauta de exportação brasileira em relação à intensidade tecnológica. Os produtos não industriais representaram participação crescente nas exportações brasileiras, ao passo que os produtos de alta intensidade tecnológica cresceram na pauta de importação. Em relação às exportações de alta intensidade tecnológica, o único setor que não apresenta défict é o aeroespacial. Como observamos no capítulo terceiro, a Embraer, principal empresa do setor, no Brasil, recebe apoio governamental desde a década de setenta, o que demonstra que essas políticas podem ter alcance de longo prazo.

O estudo realizado pelo IPEA e UFMG (2010) sobre as políticas de incentivo à inovação corrobora o pressuposto do longo prazo. Segundo esse estudo, a ampliação do FNDCT tem sido capaz de impulsionar o progresso científico e tecnológico no país. Porém, para que haja maior alcance, é necessário o aprofundamento das políticas industriais ativas no país, com a inserção de áreas tecnológicas emergentes e a articulação dessa política com as políticas de ciência e tecnologia, de maneira a constituir novas empresas em 
setores débeis como os relacionados à saúde, tecnologias da informação e comunicação, nanotecnologia e biotecnologia.

Nesse contexto, a continuidade e o aprofundamento não só das políticas como dos estudos concernentes a essa temática se mostram como um campo profícuo de análise Geopolítica nacional. Tanto a dependência tecnológica externa quanto a definição de áreas estratégicas para o desenvolvimento tecnológico nacional se revelaram como temas fundamentais. Uma Geopolítica baseada nesses pressupostos se configura como uma proposta que ultrapassa sua forte acepção ligada aos conflitos e ao militarismo. 
ALBUQUERQUE, E. da M. e; BAESSA, A. R.; SOUZA, S. G. A. de. Pesquisa e inovação em saúde; uma discussão a partir da literatura sobre economia da tecnologia'. Ciência \& Saúde Coletiva, 2003 v.8, n², pp. 277-294.

ALBUQUERQUE, M. V. de; IOZZI, F. L.; MELLO G. A. O processo de regionalização em saúde nos estados brasileiros. In: VIANA, A. L. d'Á. e LIMA, L. D de (org.). Regionalização e Relações Federativas na Política de Saúde no Brasil. Rio de Janeiro: Contra Capa, 2011, pp. 117-172.

ALMEIDA, Mansueto. Desafios da Real Política Industrial Brasileira do Século XXI. Brasília: IPEA, Texto para Discussão, n 1452, 2009.

AMSDEN, Alice. Asia's The Next Giant: South Korea and Late Industrialization. Oxford: Oxford University Press, 1989.

ANDERSON, B. A nova desordem mundial. Revista Novos Rumos. São Paulo, SP: Instituto Astrogildo Pereira, $n^{\circ}$ 21, 1993, pp. 24-29.

ANDREAZZI, M. de F. S.; KORNIS, G. E. M. Padrões de acumulação setorial: finanças e serviços nas transformações contemporâneas da saúde. Ciência \& Saúde Coletiva, v.13(5), 2008, pp. 1409-1420.

ANTAS JR., Ricardo Mendes. Território e Regulação: Espaço Geográfico, Fonte Material e Não-Formal do Direito. São Paulo, SP: FAPESP/Humanitas, 2005.

ANSELMO, R. de C. M. de S; BRAY, S. C. Geografia e geopolítica na formação nacional brasileira: Everardo Adolpho Backheuser. In: GERARDI, L. H. de O; MENDES, I. A. (org.). Do Natural, do Social e de suas Interações: Visões Geográficas. Rio Claro, SP: Programa de Pós-Graduação em GeografiaUNESP; Associação de Geografia Teorética - AGETEO, 2002.

ARBIX, G. Projeto Metodologia para Conceber e Executar Plano de Mobilização Brasileira pela Inovação Tecnológica - MOBIT. São Paulo: ABDI/CEBRAP Produto 2, 2007.

ARBIX, G.; MENDONÇA, Maurício. Inovação e competitividade: uma agenda para o futuro. In: CASTRO, A. A; LICHA, A; PINTO JR., H. Q;. SABÓIA, J. Brasil em Desenvolvimento: Economia, Tecnologia e Competitividade. v.1. Rio de Janeiro, RJ: Civilização Brasileira, 2005, pp. 233-170.

ARROYO, Maria Mónica. Territorio nacional e mercado externo. Uma leitura do Brasil na virada do século XX. [Tese]. São Paulo: Departamento de Geografia da Faculdade de Filosofia Letras e Ciências Humanas da Universidade de São Paulo, 2001. 
AVELLAR, A. P. Avaliação do impacto do PDTI sobre o gasto em atividades de inovação e em P\&D das empresas industriais. In: DE NEGRI, J. A; KUBOTA, L. C. (ed.). Políticas de Incentivo à Inovação Tecnológica. Brasília: IPEA, 2008, pp. 323- 358.

BADIE, Bertrand. O Fim dos Territórios - Ensaio sobre a Desordem Internacional e sobre a Utilidade Social do Respeito. Lisboa: Instituto Piaget, 1995.

BACKHEUSER, E. Curso de Geopolítica Geral e do Brasil. Rio de Janeiro: Biblioteca do Exército, 1948.

Problemas do Brasil - Estrutura Geopolítica. Rio de Janeiro, RJ: Biblioteca do Exército/ Omnia, 1933.

BARBOSA, D. B. Incentivos fiscais no contexto da Lei Federal de Inovação. s/l, dezembro de 2004.

BARBOSA, A. de F; MENDES, R. C; SENNES, R. Avaliação da Política Industrial, Tecnológica e de Comercio Exterior para o setor Farmacêutico. São Paulo: Febrafarma - Federação Brasileira da Indústria Farmacêutica, 2007.

BARROS, A. R. de. A Teoria da Soberania de Jean Bodin. São Paulo, SP: Unimarco Editora, 2001.

BASSET, T. J. The political ecology of peasant-herder conflicts in the northen Ivory Coast. In: COX, K. R. (ed.). Political Geography. Critical Concepts in the social sciences. London and New York: Routledge, v. 2, 2005[1988], pp.195-224.

BASTOS, V. D. Fundos Setoriais de Ciência e Tecnologia. In: PINTO, M. P. A.; BIASOTO Jr., G. Política fiscal e Desenvolvimento no Brasil. Campinas, SP: Editora da Unicamp, 2006.

BECATTINI, G. Industrial Districts: a New Approach to Industrial Change. Cheltenham, UK and Northampton, MA, USA: Edward Elgar, 2004.

BECKER, B. K. A Amazônia na estrutura espacial do Brasil. Revista Brasileira de Geografia. Rio de Janeiro: IBGE, v. 36(2), abril/junho de 1974, pp. 3-36.

. A crise do Estado e a região a estratégia da descentralização em questão. Revista Brasileira de Geografia. Rio de Janeiro, RJ: IBGE, 48, $n^{\circ} 1$, jan/março de 1986, pp. 43-62.

A Geografia e o Resgate da Geopolítica. In: Revista Brasileira de Geografia. Rio de Janeiro, RJ: IBGE, especial $n^{\circ} 2,1988$.

RJ: Garamond, 2004.

Amazônia: Geopolítica na Virada do III Milênio. Rio de Janeiro, 
. Geopolítica da Amazônia. Estudos Avançados. São Paulo, 2005, v.19, n 53 , pp.71-86.

BECKER, B. K.; EGLER, C. A. G. Brasil: uma nova potência regional na economia-mundo. Rio de Janeiro, RJ: Bertrand Brasil, 2003[1992].

BENAKOUCHE, T. Tecnologia é Sociedade: contra a noção de impacto tecnológico. Cadernos de Pesquisa. Florianópolis, SC: PPGSP/UFSC, $\mathrm{n}^{\circ} 17$, 1999, pp.1-28.

BENKO, G. Economia, Espaço e Globalização: na aurora do século XXI. São Paulo, SP: Hucitec, 1999.

BERNAL, J. D. La Ciência en La Historia. La Habana, Cuba: Editorial Científico-Técnica, Tomo 1, 2007 [1953].

BICUDO JR., Edison. Produção de medicamentos e território: por uma concepção horizontal do desenvolvimento. In: VIANA, A. L. Á; IBAÑEZ, N.; ELIAS, P. E. M. Saúde, Desenvolvimento e Território. São Paulo, SP: Hucitec, 2009, pp. 151-191.

BOBBIO, N. Estado, Governo e Sociedade. Para uma teoria geral da política. Rio de Janeiro: Paz e Terra, 1987.

BOWMAN, I. Geography VS. Geopolitics. In: COX, K. R. (ed.). Political Geography. Critical Concepts in the social sciences. London and New York Routledge, vol. 1, 2005[1988], pp. 68-80.

BRASIL/PRESIDÊNCIA DA REPÚBLICA. Casa Civil. Diretrizes de política industrial, tecnológica e de comércio exterior. Brasília, DF: Casa Civil, 2003.

BRASIL. Ministério da Saúde. Programa Mais Saúde: Direito de Todos. 20082011. Brasília, DF: MS, dezembro de 2007.

. Ministério da Ciência e Tecnologia. Plano de Ação 2007-2010. Ciência, Tecnologia e Inovação para o Desenvolvimento Nacional. Brasília, DF: MCT, 2007a.

. Ministério do Planejamento, Orçamento e Gestão. Secretaria de Planejamento e Investimentos Estratégicos. Estudo da Dimensão Territorial para o Planejamento. Brasília, DF: MP, 2008.

- Ministério da Ciência e Tecnologia. Relatório Anual de Utilização dos Incentivos Fiscais. Ano Base 2007. Lei N 11.196/05. Brasília, DF: MCT, 2008a.

CADERNO DE HISTORIA DAS CIÊNCIAS. Instituto Butantan. Entrevista com Bertha Becker. Série Depoimentos, v.4, n.2, junho/dezembro, 2008, p. 103-132. 
CAPANEMA, L. X. de L. A indústria farmacêutica brasileira e a atuação do BNDES. BNDES Setorial. Rio de Janeiro, RJ: BNDES, $n^{\circ}$ 23, 2006.

CAPANEMA, L. X. de L.; PALMEIRA FILHO, P. L.. A cadeia farmacêutica e a Política Industrial: uma proposta de inserção do BNDES. BNDES Setorial. Rio de Janeiro, RJ: BNDES, n 19, 2004.

CAPANEMA, L. X. de L.; PALMEIRA FILHO, P. L.; PIERONI, J. P. Apoio do BNDES a Complexo Industrial da Saúde: experiência do Profarma e seus desdobramentos. BNDES Setorial. Rio de Janeiro, RJ: BNDES, n² 27, 2008.

CAPELLO, R. Space, growth and development theories. In: Capello, R; Nijkamp, P. (ed.) The Handbook of Regional Growth and Development Theories. Chelthan, UK: Edward Elgar Publishing Limited, 2009.

CAPELLO, R; NIJKAMP, P. Introduction: regional growth and development theories in the twenty-first century - recent theoretical advances and future challenges. In: Capello, R; Nijkamp, P. (ed.) The Handbook of Regional Growth and Development Theories. Chelthan, UK: Edward Elgar Publishing Limited, 2009.

CARVALHO, D. de; CASTRO, T. de. Geografia Humana. Política e Econômica. Rio de Janeiro, RJ: Conselho Nacional de Geografia, 1963.

CASSIOLATO, J. E; LASTRES, H. M. M. O foco em arranjos produtivos e inovativos locais de micro e pequenas empresas. In: LASTRES, H.M.M; CASSIOLATO, J.E.e MACIEL, M.L. (org.) Pequena empresa: cooperação e desenvolvimento local. Rio de Janeiro, RJ: Relume Dumará Editora, 2003.

$$
\text { Sistemas de Inovação e }
$$

Desenvolvimento: as implicações de política. São Paulo em Perspectiva. São Paulo, v. 19 (1), janeiro/março de 2005, pp.34-45.

Inovação e sistemas de inovação:

relevância para a saúde. RECIIS - R. Eletr. De Com. Inf. Inov. Saúde. Rio de Janeiro, v. 1(1), janeiro/junho de 2007, pp.153-162.

CASTRO, I. E. de. Geografia e Política. Território, Escalas de Ação e Instituições. Rio de Janeiro, RJ: Bertrand Brasil, 2005.

CASTRO, T. de. Nossa América: geopolítica comparada. Rio de Janeiro, RJ: Biblioteca do Exército, 1994.

CATAIA, M. Território Nacional e Fronteiras Internas. A Fragmentação do Território Brasileiro. [Tese]. São Paulo: Departamento de Geografia da Faculdade de Filosofia Letras e Ciências Humanas da Universidade de São Paulo, 2001.

A geopolítica das fronteiras internas na constituição do território: o caso da criação de novos municípios na região Centro-Oeste do Brasil durante o regime militar. Scripta Nova. Revista electrónica de geografía y 
ciencias sociales. Barcelona: Universidad de Barcelona, v. X, $\mathrm{n}^{\circ} 218$ (22). Acessado em: 1 de agosto de 2006. Disponível em: http://www.ub.es/geocrit/sn/sn-218-22.htm

CGEE. Descentralização do Fomento à Ciência, Tecnologia e Inovação no Brasil. Brasília, DF: Centro de Gestão e Estudos Estratégicos, 2010.

CHANG, Ha-Joon. Chutando a Escada: a estratégia do desenvolvimento em perspective histórica. São Paulo, SP: Editora UNESP, 2004.

COHEN, S. B. Geopolitical realities an United States foreing policy. Political Geography, ${ }^{\circ} 22,2003, p p .1-33$.

CONTI, S.. Espaço global versus espaço local: perspectiva sistêmica do desenvolvimento local. In: DINIZ, C. C; LEMOS, M. B. (org). Economia e Território. Belo Horizonte, MG: Editora UFMG, 2005, pp. 209-252.

CORDEIRO, Hésio. A Indústria da Saúde no Brasil. Rio de Janeiro: Edições Graal, 1980.

CORDER, S; SALLES-FILHO, S.. Aspectos Conceituais do Financiamento à Inovação. Revista Brasileira de Inovação, Rio de Janeiro, v. 5(1) janeiro/junho de 2006, pp. 33-76.

COSTA, W. M. da. Geografia Política e Geopolítica: Discursos Sobre o Território e o Poder. São Paulo, Hucitec-Edusp, 2010[1992].

Políticas Territoriais Brasileiras no Contexto da Integração SulAmericana. Revista Território, Rio de Janeiro, ${ }^{\circ}$ 7, 1999, pp.25-41.

Política e Território em tempos de mudanças globais. [Tese de Livre-Docência em Geografia Política]. São Paulo: Departamento de Geografia da Faculdade de Filosofia Letras e Ciências Humanas da Universidade de São Paulo, 2005.

. O Brasil e a América do Sul: cenários geopolíticos e os desafios

da integração. Confins [Online], v. (7), 2009. Disponível em: http://confins.revues.org/6107 ; DOI : 10.4000/confins.6107

COUTINHO, L. G.. Macroeconomic Regimes and Business Strategies: an Alternative Industrial Policy for Brazil in the Wake of the 21st Century. In: CASSIOLATO, J. E; LASTRES, H. M. M.; MACIEL, M. L. (org). Systems of Innovation and Development: Evidence from Brazil. Sussex: Sussex University, 2003; v. 1, pp.311-329.

COUTINHO, L.; SARTI, F. A política industrial e a retomada do desenvolvimento. In: LAPLANE, M.; COUTINHO, L.; HIRATUKA, C. (org.). Internacionalização e Desenvolvimento da Indústria Brasileira. São Paulo, SP: Editora da Unesp; Campinas, SP: Instituto de Economia da Unicamp, 2003, pp. 329-344. 
COUTO e SILVA, G.. Geopolítica e Poder. Rio de Janeiro, RJ: UniverCidade, 2003.

Olympio Editora, 1967.

Geopolítica do Brasil. Rio de Janeiro, RJ: Livraria José

COX, K. R. Spaces of dependence, space of engagement and the politics of scale, or: looking for local politics. In: COX, K. R. (ed.). Political Geography. Critical Concepts in the social sciences. London and New York: Routledge, vol. I, 2005[1988], pp. 226-255.

CRUZ, Carlos Henrique de Brito. Ciência, Tecnologia e Inovação no Brasil: desafios para o período 2011 a 2015. Revista Interesse Nacional, v. 10 (3), julho a setembro de 2010, pp. 75-91.

DAGNINO, R. P. A relação pesquisa-produção: em busca de um enfoque analítico. In: SANTOS, L. W. et al. (org). Ciência, Tecnologia e Sociedade: o Desafio da Interação. Londrina, PR: IAPAR, 2004.

Sociedade. Campinas, SP: Komedi, 2010.

DAGNINO, R. P.; THOMAS, H. Planejamento e políticas públicas de inovação: em direção a um marco de referência latino-americano. Planejamento e Políticas Públicas. Brasília, DF: IPEA, n.23, 2001.

DE NEGRI, Fernanda ...et al. Metodologia de Avaliação dos Resultados de Conjuntos de Projetos Apoiados dor Fundos de Ciência, Tecnologia e Inovação $(\mathrm{C}, \mathrm{T} \& \mathrm{I})$. Relatório $\mathrm{n}^{\circ} 2$. Perfil das Empresas Integradas ao Sistema Federal de C,T\&I no Brasil e aos Fundos Setoriais: uma Análise Exploratória. s/l, 2010.

DE NEGRI, J. A; SALERNO, M. S; CASTRO, A. B. de. Inovações, padrões tecnológicos e desempenho das firmas industriais brasileiras. In: DE NEGRI, J. A; SALERNO, M. S. (org). Inovações, Padrões Tecnológicos e desempenho das firmas industriais brasileiras. Brasília, DF: IPEA, 2005, pp.5-48.

DINIZ, C. C. de. Globalização, escalas territoriais e política tecnológica regionalizada no Brasil. Belo Horizonte, MG: UFMG/Cedeplar, Texto para discussão; $n^{\circ}$ 168, 2001.

DINIZ, C. C. de.; LEMOS, M. B. (org.). Economia e Território. Belo Horizonte, MG: Editora UFMG, 2005.

DINIZ, C. C. de.; GONÇALVES, E. Economia do conhecimento e desenvolvimento regional no Brasil. In: DINIZ, C. C. de.; LEMOS, Mauro Borges (org). Economia e Território. Belo Horizonte, MG: Editora UFMG, 2005, pp.131-170.

DOSSE, F. História do estruturalismo. v.1: O campo do signo - 1945/1966. Bauru, SP: Edusc, 2007. 
. História do estruturalismo. v.2: O canto do cisne - de 1967 a nossos dias. Bauru, SP: Edusc, 2007.

DUCH, N; MONTOLIO, D; MEDIAVILLA, M.. Evaluating the impact of public subsidies on a firm's performance: a two-stage quasi-experimental approach. In: Investigaciones Regionales, Sección Artículos, 16, 2009, pp.143-165.

DUNCAN, S.; GOODWIN, M.; HALFORD, S.. Policy variations in local states. In: COX, Kevin R. (ed.). Political Geography. Critical Concepts in the social sciences. London and New York: Routledge, v.1, 2005[1988], pp. 271-292.

EDLER, J; GEORGHIOU, L.. Public procurement and innovation: Resurrecting the demand side. Research Policy: Manchester, UK, 36, 2007, pp.949-963.

EGLER, C. Questão regional e gestão do território no Brasil. In: CASTRO, I. E.; CORREAA, R. L.; GOMES, P. C. C.. Geografia, Conceitos e Temas. Rio de Janeiro, RJ: Bertrand Brasil, 1995, pp.207-238.

ELLUL, Jacques. A Técnica e o Desafio do Século. Rio de Janeiro, RJ: Ed. Paz e Terra, 1968 [1954].

ESCRIBÁ, F. J; MURGUI, M. J. El capital tecnológico como factor de producción en las regiones españolas, 1980-2000. In: Investigaciones Regionales, Sección Artículos, v. 10, 2007, pp.33-52.

EVANS, Peter. Instituciones y desarrollo en la era de la globalización neoliberal. Colección En Clave de Sur. $1^{\text {a }}$ Edición: ILSA. Bogotá, Colombia, 2007.

EUROPEAN COMMISSION. Guide on dealing with innovative solutions in public procurement $\mathbf{- 1 0}$ elements of good practice. Luxembourg: Office for Official Publications of the European Communities, 2007.

FAPESP. Fundação de Amparo à Pesquisa do Estado de São Paulo. Indicadores de FAPESP de C\&T\&I em São Paulo, 2010.

FARIAS, H. C. O BNDES e as privatizações no uso do território brasileiro. [Dissertação]. Campinas, SP: Instituto de Geociências da Universidade Estadual de Campinas, 2008.

FINEP. Financiadora de Estudos e Projetos. Agência Brasileira de Inovação. Formas de Atuação. 2004.2 Disponível em: http://www.finep.gov.br/o_que_e_a_finep/Caderno\%20Formas\%20de\%20Atua \%E7\%E3o\%20FINEP.pdf. Acessado em: 25/01/2010.

S/l. s/d. . Financiadora de Estudos e Projetos. Relatório de Gestão 2009. 
S/l. s/d. Financiadora de Estudos e Projetos. Relatório de Gestão 2008. Financiadora de Estudos e Projetos. Relatório de Avaliação do Programa de Subvenção Econômica. s/l. Janeiro de 2010.

FINGER, M. The Military, the Nation State and the Environment. In: O TUATHAIL, G; DALBY, S; ROUTLEGDE, P. The Geopolitical Reader. Routledge . London and New York, 1998[1991], pp. 223-230.

FIORI, Jose Luís. O Poder Global. São Paulo: Boitempo Editorial, 2007a. Nicholas Spykman e a América Latina. Valor Econômico, São Paulo, 5 de dezembro, 2007b.

FLEURY, S; GERALDO, V.; MAGALHÃES JÚNIOR, H. M; TEMPORÃO, J. G; Definição e perspectivas do PAC da Saúde. Sala de Convidados - Canal Saúde / FIOCRUZ. Data: 28/01/08 das 12h05min às 14h. Disponível em: www.canalsaude.fiocruz.br. Acessado em: 28/01/08.

FOUCHER, Michel. Fronts et Forntières. Un Tour du Monde Géopolitique. Paris: Fayard, 1991.

FRATESI, U. The spatial diffusion of innovations and evolution of regional disparities. In: Investigaciones Regionales, Sección Artículos, 11, 2007, pp.131-160.

FREEMAN. C. Technological infrastructure and international competitiveness. Rio de Janeiro: The First Globelics Conference 'Innovation Systems and Development Strategies for the Third Millennium', November, 2003[1982].

FURTADO, J.; GARCIA, R; SUZIGAN, W; Sistemas locais de produção/inovação: metodologia para identificação, estudos de casos e sugestão de políticas. In: DINIZ, C. C; LEMOS, M. B. (org.). Economia e Território. Belo Horizonte, MG: Editora UFMG, 2005, pp.287-320.

. The national innovation systems in historical perspective. Cambridge Journal of Economics, 1995 v.19, n 1, pp. 5-24.

GADELHA, C. A. G.; TEMPORÃO, J. G.. A indústria de vacinas no Brasil: desafios e perspectivas. Rio de Janeiro: Publicação do BNDES, Relatório Técnico 1999.

GADELHA, C. A. G. Estado e Inovação: uma perspectiva evolucionista. Revista de Economia Contemporânea, Rio de Janeiro, 2002, v.6, n 2, pp. 85-117.

. O complexo industrial da saúde e a necessidade de um enfoque dinâmico na economia da saúde. Ciência \& Saúde Coletiva, 2003 v.8, nº 2, pp.521-535. 
. O Complexo Industrial da Saúde: desafios para uma política de inovação e desenvolvimento. In: BUSS, P. M; TEMPORÃO, J. G; CARVALHEIRO, J. da R. (org.). Vacinas, soros \& imunizações. Rio de Janeiro, RJ: Editora FIOCRUZ, 2005, v.1, pp. 69-90.

.Desenvolvimento, complexo industrial da saúde e política industrial. Revista Saúde Pública, São Paulo, 2006, v. 40, nº especial.

GADELHA, C. A. G.; FIALHO, B. de C.; QUENTAL, C.. Saúde e inovação: uma abordagem sistêmica das indústrias de saúde. Cadernos de Saúde Pública. Rio de Janeiro, v. 19 (9), jan.-fev., 2003, pp. 47-59.

GARCIA, R. et al. O papel da proximidade geográfica para a interação universidade-empresa. In: Anais do I Simpósio Internacional de Geografia do Conhecimento e da Inovação, Recife, PE, 2011.

GELIJNS, A.; ROSENBERG, N. The changing nature of medical technology development. In: DAWKINS, H. GELIJNS, A.; ROSENBERG, N.; Sources of medical technology: universities and industry. Washington: National Academy, 1995, pp. 3-14.

GLASSMAN, J. State power beyond the 'territorial trap': the internalization of the state. In: COX, K. R. (Ed.). Political Geography. Critical Concepts in the social sciences. London and New York: Routledge, vol. 2, 2005[1999], pp.7-37.

GODIN, B. National Innovation System: The System Approach in Historical Perspective. Canada: Project on the History and Sociology os STI Statistics, Working Paper n 38, 2007.

GONÇALVES DA SILVA, C; MELO, L. C. P. de (coord.). Ciência, tecnologia e inovação: desafio para a sociedade brasileira - Livro Verde. Brasília: MCT/ Academia Brasileira de Ciências, 2001.

GUIMARÃES, Eduardo Augusto. Políticas de Inovação: Financiamentos e Incentivos. In: DE NEGRI, João Alberto; KUHBOTA, Luis Claudio (Ed.). Políticas de Incentivo à Inovação Tecnológica. Brasília, DF: IPEA:2008, pp. $149-228$.

HAGERSTRAND, T. The propagation of innovation waves. In: WAGNER, P. L; MIKESELL, M. W. Readings in Cultural Geography. Chicago/London: The University of Chicago Press, 1962, pp. 355-368.

HAGERSTRAND, T. Innovation Difusion as a Spatial Process. Chicago/London: The University of Chicago Press, 1967.

HARTSHORNE, R. The functional approach in political geography. In: Annals of the Association of American Geographers, 1950, vol 40, pp.95-130.

HARVEY, D. Condição Pós-Moderna. Uma pesquisa sobre as origens da mudança cultural. São Paulo, SP: Edições Loyola, 1992[1989]. 
2005.

A Produção Capitalista do Espaço. São Paulo, SP: Annablume,

HAUSHOFER, R. The functional approach in political geography. In: Annals of the Association os Americam Geographers. 1950, Volume 40, pp.95-130.

Defense of German Geopolitics. In: Ó TUATHAIL, G; DALBY, S;

ROUTLEGDE, P. The Geopolitical Reader. London and New York: Routledge, 1998, pp.40-46.

HYNDMAN, J. Border Crossing. Antipode, v. 29, n² 2, 1997, pp.149-176.

IBANEZ, N.; WEN, F. H.; FERNANDES, S. C. G. A autosuficiência na produção de imunobiológicos e a criação do Centro de Biotecnologia do Instituto Butantan. Cadernos de História da Ciência. São Paulo, Laboratório de História da Ciência, Instituto Butantan, v.3, n 1, julho/dezembro de 2007, pp.934.

IBANEZ, Pablo. Guerra Fiscal e Território: a Perversidade dos Incentivos Territoriais. [Dissertação]. São Paulo, SP: Departamento de Geografia da Faculdade de Filosofia Letras e Ciências Humanas da Universidade de São Paulo, 2006.

IEDI. Instituto de Estudos para o Desenvolvimento Industrial. Desafios da Inovação. Incentivos para Inovação: o que falta ao Brasil. s/l. 2010.

ISNARD, H. O espaço geográfico. Coimbra, Portugal: Livraria Almeida, 1982.

JASANOFF, S. New Modernities: Reimagining Science, Technology and Development. Environmental Values, v.11, n³ 3, 2002. pp. 253-276.

KIM, L; NELSON, R. R. Introdução: A tecnologia e a industrialização em economias de industrialização recente. In: KIM, L; NELSON, R. R. (org.) Tecnologia, Aprendizado e Inovação. As experiências das economias de industrialização recente. Campinas, SP: Editora da Unicamp, 2005, pp.11-22.

KUBOTA, L. C. ; SALERNO, M. S; Estado e Inovação. In: DE NEGRI, J. A.; KUHBOTA, L. C. (ed.). Políticas de Incentivo à Inovação Tecnológica. Brasília: IPEA, 2008, pp.13-64.

LACOSTE, Y. A Geografia - Isso serve, em primeiro lugar, para fazer a Guerra. Campinas, SP: Papirus, 2006[1985].

LALL, S. A mudança tecnológica e a industrialização nas economias de industrialização recente da Ásia: conquistas e desafios. In: KIM, L; NELSON, R. R. (org.) Tecnologia, Aprendizado e Inovação. As experiências das economias de industrialização recente. Campinas, SP: Editora da Unicamp, 2005, pp.25-99. 
LASTRES, H. M. M. e CASSIOLATO, J. E. Desafios e oportunidades para o aprendizado em sistemas produtivos e inovativos na América Latina. In: DINIZ, C. C; LEMOS, M. B. (org.). Economia e Território. Belo Horizonte, MG: Editora UFMG, 2005, pp.321-338.

LIMA, J. P. R; FERNANDES, A. C. Demandas e ofertas tecnológicas em economias retardatárias: anotações a partir de dois segmentos econômicos no Nordeste brasileiro. Revista Brasileira de Inovação, Rio de Janeiro, julho/dezembro 2009, v.8, $n^{\circ} 2$, pp.303-340.

LUNA, F; MOREIRA, S; GONÇALVES, A. Financiamento à inovação. In: DE NEGRI, J. A; KUHBOTA, L. C. (Ed.). Políticas de Incentivo à Inovação Tecnológica. Brasília, DF: IPEA: 2008, pp.229-262.

LUNDVALL, Bengt-Ake. National Innovation System: Towards a Theory of Innovation and Interactive Learning. London: Pinter, 1992.

LUNDVALL, B-A.; BORRÁS, S. Science, Technology and Innovation Policy. In: FAGERBERG J; MOWERY D.C; Nelson R.R. The Oxford Handbook of Innovation. Oxford: Oxford University Press, 2005, pp. 599-631.

MACHADO, L. O. Sociedade urbana, inovação tecnológica e nova geopolítica. Revista Brasileira de Geografia. Rio de Janeiro: IBGE, janeiro/dezembro de 1993, v.55, n 1/4, pp.5-13.

Medidas institucionais para o controle do tráfico e drogas e da lavagem de dinheiro e seus feitos geoestratégicos na região Amazônica brasileira. Cadernos IPPUR, Rio de Janeiro, n 1 (21), 2007, pp.9-31.

. Espaços Transversos: tráfico de drogas ilícitas e a geopolítica da segurança. In: Fundação Alexandre de Gusmão/Ministério das Relações Exteriores. (Org.). Geopolítica das Drogas. Textos Acadêmicos. Brasília: Fundação Alexandre de Gusmão, v.1, 2011, pp.97-117.

MACHADO, T. A; FERNANDES, A. C. O conhecimento e a inovação como elementos da ação social das empresas na sociedade informacional - a responsabilidade social empresarial (rse) ordenando o território. In: Anais do I Simpósio Internacional de Geografia do Conhecimento e da Inovação, Recife, PE, 2011.

MACKINDER, H. J. The Geographical Pivot of History. In: BLIJ, H. J. Systematic Political Geography. New York: John Wiley \& Sons, 1967[1904].

MANN, M. Has globalization ended the rise and rise of the nation-state. In: COX, K. R. (ed.). Political Geography. Critical Concepts in the social sciences. London and New York: Routledge, vol. 2, 2005[1997], pp.113-136.

. The autonomous power of the state: its origins, mechanisms and results. In: COX, K. R. (Ed.). Political Geography. Critical Concepts in the 
social sciences. London and New York: Routledge, vol. I, 2005[1984], p.328353.

MARTIN, A. R. Brasil, Geopolítica e poder mundial - o anti-Golbery. Política e Território em tempos de mudanças globais. [Tese de Livre-Docência em Geografia Política] São Paulo: Departamento de Geografia da Faculdade de Filosofia, Letras e Ciências Humanas da Universidade de São Paulo, 2007.

MATTOS, C. de M. Brasil, Geopolítica e Destino. $2^{\mathrm{a}}$ ed. Rio de Janeiro, RJ: Biblioteca do Exercito/ Livraria José Olympio Editora , 1979.

. Uma Geopolítica Pan-Amazônica. Rio de Janeiro, RJ: Livraria José Olympio Editora, 1980.

- Geopolítica e Trópicos. Rio de Janeiro, RJ: Biblioteca do Exercito/ Livraria José Olympio Editora, 1984.

MCT/CGEE. $3^{a}$ Conferência Nacional de Ciência, Tecnologia e Inovação : síntese das conclusões e recomendações. Brasília, DF: Ministério da Ciência e Tecnologia, Centro de Gestão de Estudos Estratégicos, 2006.

$4^{a}$ Conferência Nacional de Ciência, Tecnologia e Inovação para o Desenvolvimento Sustentável. Brasília: Ministério da Ciência e Tecnologia, Centro de Gestão de Estudos Estratégicos, 2010.

MELLO, L. I. A. Quem tem medo da Geopolítica. São Paulo, SP: Hucitec/Edusp, 1999.

MELO, Lúcia Carvalho Pinto de ; SILVA, Cylon Gonçalves da (coord.). Ciência, tecnologia e inovação: desafio para a sociedade brasileira - Livro Verde. Brasília: Ministério da Ciência e Tecnologia / Academia Brasileira de Ciências, 2001.

MIGLINO, M. A. P. Inovação: o local importa? Um ensaio sobre os nexos entre inovação e espaço segundo autores contemporâneos selecionados. [Dissertação]. Campinas, SP: Programa de Pós-Graduação em Política Cientifica e Tecnológica do Instituto de Geociências da Universidade Estadual de Campinas, 2003.

MIYAMOTO. S. O pensamento geopolítico brasileiro (1920-1980). [Dissertação]. São Paulo, SP: Departamento de Geografia da Faculdade de Filosofia, Letras e Ciências Humanas da Universidade de São Paulo, 1981.

. Do discurso triunfalista ao pragmatismo ecumênico Geopolítica e política externa no Brasil pós-64. [Tese]. São Paulo, SP: Departamento de Geografia da Faculdade de Filosofia, Letras e Ciências Humanas da Universidade de São Paulo, 1985. 
MOKYR, Joel. The intellectual origins of modern economic growth. The Journal of Eonomic History. Cambridge: University Press, vol. $65, n^{\circ} 2$, jun. 2005, pp. 285-351.

MOODIE, A. E. Geografia e Política. Rio de Janeiro: Zahar Editores, 1965.

MOTOYAMA, S. (org.). Prelúdio para uma História: Ciência e Tecnologia no Brasil. São Paulo, SP: EDUSP, 2004.

MYRDAL, G. Economic theory and under-developed regions. London: Duckworth, 1957.

NELSON, R. Schumpeter e as pesquisas contemporâneas sobre a economia da inovação. In: NELSON, R. As fontes do crescimento econômico. Campinas, SP: Editora Unicamp, 2006.

NEUMANN, Roderick P. Local challenges to global agendas: conservation, economic liberalization and the pastoralist rights movement in Tanzania. In: COX, K. R. (ed.). Political Geography. Critical Concepts in the social sciences. London and New York: Routledge, vol. II, 2005[1995], pp.225-244.

NORTH, Douglass C. Institutions, Institutional Change and Economic Performance. Cambridge: Cambridge University Press, 1990.

The contribution of the new institutional economics to a undertanding of the transition problem. Unite Nations University. Winder Annual Lectures 1, 1997.

Ó TUATHAIL, G. Thinking critically about geopolitcs. In: Ó TUATHAIL, G; DALBY, S; ROUTLEGDE, P. The Geopolitical Reader. London and New York: Routledge, 1998, pp.1-14.

. The postmodern geopolitical Condition: States, statecraft and security at the millennium. In: Annals of the Association of American Geographers, 2000, v.90, $n^{\circ} 1$, pp.166-178.

OCDE. Main Science and Technology Indicators database, 2010.

OCDE. Proposed guidelines for collecting and interpretinginnovation data (Oslo Manual). Paris: 1992.

OHMAE, K. O Fim do Estado-Nação. Rio de Janeiro, RJ: Campus, 1996.

OMS. Estadísticas Sanitarias Mundiales. 2009.

PACHECO, C. A.. Políticas públicas, intereses y articulación política: cómo se gestaron las recientes reformas al sistema de ciencia y tecnología en Brasil. Santiago do Chile: CEPAL, Serie Políticas Sociales, $n^{\circ}$ 103, 2005. 
PERREIRA, J. C. R.; BALTAR, V. T. e MELLO, D. L. de. Sistema nacional de inovação em saúde: relações entre áreas da ciência e setores econômicos. Revista Saúde Pública, São Paulo, 38c(1), 2004, pp. 1-8.

PIRRÓ E LONGO, W; DERENUSSON, M. S..FNDCT, 40 Anos. Revista Brasileira de Inovação. Rio de Janeiro, v. 8, $\mathrm{n}^{\circ}$ 2, julho/dezembro 2009, pp.515-533.

PORTO, G.S.; SCORZAFAVE, M. C. B. Parque Tecnológico De Ribeirão Preto Centro Tecnológico. Resumo do Projeto de Infra-estrutura e Serviços para o Setor de Biotecnologia e Saúde. Ribeirão Preto: Fipase; 2007.

QIAN, Yingyi. How reform worked in China. In Rodrik, Dani (ed.) In Search of Prosperity: Analytic Narratives on Economic Growth. Princeton: University Press, 2003, pp. 297-333.

QUESADA, J.. Política regional de innovación. Investigaciones Regionales, Sección Panorama y Debates, $n^{\circ} 12,2008, p p .181-210$.

RAFFESTIN, C. Por Uma Geografia Do Poder. São Paulo, Ática, 1993.

RATZEL, F. O solo, a sociedade e o Estado. Revista do Departamento de Geografia. São Paulo, 1983[1898-1899], pp.95-101. Fayard, 1987[1897].

La Géographie Politique. Les concepts fondamentaux. Paris:

ROBBINS, P. Authority and environment: institutional landscapes in Rajastham, India. In: COX, K. R. (ed.). Political Geography. Critical Concepts in the social sciences. London and New York: Routledge, vol. II, 2005[1998], pp.289329.

RODRIGUES, L. A. Geopolítica do Brasil. Rio de Janeiro, RJ: Biblioteca Militar, 1947.

ROGERS, E. M. Diffusion of innovations. New York: The Free Press, 1962.

ROSENBERG, N. Perspectives on technology. Cambridge: Cambridge University Press, 1976.

RUTHERFORD, Malcolm. Institutions in Economics. The Old and the New Institutionalism. Cambridge: Cambridg University Press, 1994.

SANGUIN, A-L. La Geographie Polotique. Paris: PUF, 1977.

SANTOS, M. O trabalho do geógrafo no Terceiro Mundo. São Paulo: Hucitec, 1996[1978]. 
[1978].

. Por uma Geografia Nova. $4^{a}$ ed. São Paulo: Hucitec, 1997 Hucitec, 1979.

Economia Espacial: Críticas e Alternativas. São Paulo:

O Espaço Dividido. Os dois Circuitos Espaciais da Economia Urbana dos Países Subdesenvolvidos. São Paulo, SP: Edusp, 2004[1979].

Técnica, espaço, tempo; globalização e meio técnicocientífico informacional. $3^{a}$ ed. São Paulo: Hucitec, 2008 [1994].

. A natureza do espaço, técnica e tempo, razão e emoção. $2^{a}$ ed. São Paulo: Hucitec, 1997.

SCHUMPETER, J. A.. Economic Theory and Entrepreneurial History. Change and the Entrepreneur: Postulates and Patterns of Entrepreneurial History. Cambridge-Mass: Harvard University Press, 1949.

$\overline{\text { Zahar, } 1984 .}$

Capitalismo, Socialismo e Democracia. Rio de Janeiro, RJ:

SHAW, M.. The state of globalization: towards a theory of state transformation. In: COX, K. R. (Ed.). Political Geography. Critical Concepts in the social sciences. London and New York: Routledge, v. 1, 2005[1997], pp.398-413.

SHEARMUR R, DOLOREUX D. Science parks: actors or reactors? Canadian science parks in their urban context. Environment and Planning A. 32, 2000, pp.1065-1082.

SHIVA, Vandana. The Greening of Global Reach. In: Ó TUATHAIL, G; DALBY, S; ROUTLEGDE, P. The Geopolitical Reader. London and New York: Routledge, 1998[1993], pp.231-236.

SILVA, A. B. da; FARIAS, H.. O BNDES e as empresas de consultoria na reorganização do território brasileiro na década de 1990. Redes. Santa Cruz do Sul, RS, v.13, n³, setembro/dezembro de 2008, pp. 99-120.

SILVA, C. A. F. da. Os avatares da teoria da difusão espacial: uma revisão teórica. Revista Brasileira de Geografia. Rio de Janeiro: IBGE, v. 57, $\mathrm{n}^{\circ} 1$, Janeiro/março de 1995, pp.25-51.

SILVEIRA, Maria Laura. Uma situação geográfica: do método à metodologia. Revista Território, nº 6 (4), jan/jun 1999, pp. 21-28.

SLATER, David. The geopolitical imagination and the enframing of development theory". In: COX, K. R. (ed.). Political Geography. Critical Concepts in the social sciences. London and New York: Routledge, vol. 2, 2005[1993], pp.137168. 
SPYKMAN, N. J.. America's Strategy in a World Politics. The United States and the Balance of Power. News Brunswick/New Jersey: Transaction Publishers, 2007[1942].

STEINER, João E. (coord.). Estruturação da Secretaria Técnica do Sistema Paulista de Parques Tecnológicos - Funções e Atividades. Relatório Científico. Secretaria de Desenvolvimento e Fundação de Amparo à Pesquisa do Estado de São Paulo, 2007.

STIGLITZ, J. E. Some lessons from the East Asian miracle. The World Bank Research Observer. v.2, $n^{\circ} 11$, Agosto de 1996, pp.151-177.

STORPER, M. The resurgence of regional economies, ten years later: the region as a nexus of untraded interdependencies. European Urban and Regional Studies. ${ }^{\circ}$ 2, Julho de 1995, pp.191-221.

SZMRECSÁNYI, T. Ideias Fundadoras. Revista Brasileira de Inovação. FINEP. v.1, n² 2, Julho/dezembro de 2002, pp.201-224.

TAN, J. Growth of industry clusters and innovation: Lessons from Beijing Zhongguancun Science Park. Journal of Business Venturing, 21, 2006, pp. 827-850.

TARTARUGA, Iván G. Peyré. As inovações nos territórios e o papel das universidades: notas preliminares para o desenvolvimento territorial no Estado do Rio Grande do Sul. Porto Alegre, RS: Secretaria do Planejamento e Gestão/Fundação de Economia e Estatística Siegfried Emanuel Heuser, Textos para Discussão N 8, 2010.

TAYLOR, P. A materialist framework for political geography. In: COX, K. R. (Ed.). Political Geography. Critical Concepts in the social sciences. London and New York: Routledge, vol. I, 2005[1981], pp.153-180.

TOSTA, O. Teorias Geopolíticas. Rio de Janeiro, RJ: Biblioteca do Exército, 1984.

TRAVASSOS, M. Projeção Continental do Brasil. São Paulo, SP: Cia. Editora Nacional, 1938. RJ: José Olympio, 1942.

Introdução à Geografia das Comunicações. Rio de Janeiro,

VALOR ECONÔMICO. Votorantim eleva aposta na cana. Jornal Valor Econômico, São Paulo, 26 mar. 2003.

. Investidores financiam mapeamento genético. Jornal Valor Econômico, São Paulo, 23 abr. 2003.

- Capital de risco investe menos em 6 meses, mas

privilegia novas firmas. Jornal Valor Econômico, São Paulo, 14 nov. 2003. 
São Paulo, 04 jun. 2004.

Falta de lei dificulta pesquisa. Jornal Valor Econômico,

Alellyx mapeia genoma do vírus da leprose dos citros.

Jornal Valor Econômico, São Paulo, 08 mar. 2005.

- Brasil lidera pesquisa com cana transgênica. Jornal

Valor Econômico, São Paulo, 13 mar. 2005.

- Biotecnologia atrai capital privado. Jornal Valor Econômico, São Paulo, 08 ago. 2005.

. Pouca verba para pesquisas com cana. Jornal Valor Econômico, São Paulo, 13 mar. 2006.

. Votorantim avalia vender patente de cana transgênica ao exterior. Jornal Valor Econômico, São Paulo, 28 ago. 2006.

. Investimento público em pesquisa agrícola perde fôlego

e espaço. Jornal Valor Econômico, São Paulo, 06 nov. 2006.

. Capital sai em busca de projetos mais maduros Intel.

Jornal Valor Econômico, São Paulo, 22 fev. 2007.

. Febre do etanol valoriza as pesquisas da CanaVialis.

Jornal Valor Econômico, São Paulo, 05 mar. 2007.

Biotecnologia aproxima Votorantim e Monsanto. Jornal

Valor Econômico, São Paulo, 30 maio 2007.

Paulo, 06 jul. 2007.

. Pesquisas genéticas. Jornal Valor Econômico, São

. Com juros $4,5 \%$ ao ano, BNDES financia projetos de inovação de empresas do grupo Votorantim. Jornal Valor Econômico, São Paulo, 05 jul. 2007.

Monsanto paga US\$290 milhões por duas empresas do Grupo Votorantim. Jornal Valor Econômico, São Paulo, 04 nov. 2008.

Apostas financeiras sacodem a Votorantim. Jornal Valor Econômico, São Paulo, 27 nov. 2008.

- Fusões e aquisições caem $7 \%$ no ano, aponta

PricewaterhouseCoopers. Jornal Valor Econômico, São Paulo, 29 dez. 2008.

MDM agora é $100 \%$ da Monsanto. Jornal Valor

Econômico, São Paulo, 04 mar. 2009. 
. Fundo da Burrill investirá no Brasil $\mathrm{R} \$ 100$ milhões.

Jornal Valor Econômico, São Paulo, 29 jan. 2010.

. Contexto. Jornal Valor Econômico, São Paulo, 27 abr.

2010.

. Adquirida pelo Apax, Tivit mira exterior, em 11/05/2010.

VALLAUX. C. El Suelo y el Estado. Madrid: Daniel Jorro Editor, 1914.

VEDOVELLO, CA; JUDICE, V.M.M.A.M.; MACULAN, D.; Revisão crítica às abordagens a parques tecnológicos: Alternativas interpretativas às experiências brasileiras Recentes. Revista de Administração e Inovação, v. 3(2), 2006, pp. 103-118.

VERDÚ, F. F. M.. Centros tecnológicos y sistemas regionales de innovación: modelos europeos. Investigaciones Regionales, Sección Artículos. $n^{\circ} 3$, 2003, pp.129-161.

VIANA, A. L. d'Á. e ELIAS, P.. Saúde e desenvolvimento. Ciência \& Saúde Coletiva, v.12 (sup.), 2003, pp. 1765-1777.

VILLASCHI FILHO, A.. Anos 90: uma década perdida para o sistema nacional de inovação brasileiro?. São Paulo em Perspectiva. 2005, v.19, pp.3-20.

Vedovello, Judice e Maculan (2006)

WADE, Robert. Governing the Market. Princeton: Princeton University Press, 1990.

WALBY, S. Gender. Nation and states in a global era. In: COX, K. R. (Ed.). Political Geography. Critical Concepts in the social sciences. London and New York: Routledge, vol. 2, 2005[2000], pp.169-188.

WALLERSTEIN, E.. O Fim do Mundo como Concebemos. Ciência social para o século XXI. Rio de Janeiro, RJ: Editora Revan, 2002.

WEIGERT, H. W.. Geopolitica. Generales y Geógrafos. México: Fondo de Cultura Economica, 1942[1963]. 
ANEXOS 
APLICAÇÃO DO ROTEIRO DE ENTREVISTA

\section{"FUNDOS SETORIAIS E SISTEMA NACIONAL DE INOVAÇÃO: UMA ANÁLISE EXPLORATÓRIA"}

\section{DADOS CADASTRAIS DA EMPRESA}

RAZÃO SOCIAL:

NOME FANTASIA:

ENTREVISTADORES:

DATA:

DADOS DO ENTREVISTADO

NOME:

TEMPO NA EMPRESA:

CARGO NA EMPRESA:

FUNÇÃO NO PROJETO:

TELEFONE(S) PARA CONTATO:

E-MAIL:

SITE:

2. Classificação setorial:

2.1 principais áreas de negócio de atuação no Mundo: 
2.2 principais áreas de negócio de atuação no Brasil:

3. Origem do Capital:

4. Ano de Fundação (Instalação, se Empresa Multinacional) no Brasil:

5. Número de plantas industriais no Brasil:

6. Número de funcionários no Brasil:

7. Faturamento líquido Anual em $2008(R \$)$ :

\begin{tabular}{|l|l|}
\hline Corporação & Filial Brasileira \\
\hline & \\
\hline
\end{tabular}

8. Principais produtos para o mercado brasileiro e mundial:

9. Principais clientes, no Brasil e no Exterior:

10. Qual o percentual e/ou valor do investimento em P\&D?

Valor:

Percentual:

Ainda não Realiza ( )

11. Tendência quanto aos investimentos em P\&D no Brasil, nos próximos 5 anos?

( ) aumentar; percentagem
( ) manter
( ) diminuir; percentagem

12. Quais os argumentos utilizados para convencer a direção da empresa a investir em P\&D no Brasil (se o entrevistado for o proprietário, quais os motivos que $o$ induzem a esta atividade)?

13. Qual a Motivação para realizar P\&D:

Acompanhar a concorrência, no Brasil ( ) ou no Exterior ( )

Exigência do fornecedor Local ( ) ou Estrangeiro ( )

Percepção de novas oportunidades no mercado Local ( ) elou Mundial ( )

14. Na estrutura organizacional da empresa existe um departamento específico para a P\&D?

15. A empresa tem de patentes depositadas

( ) no Brasil; Quantas

( ) no exterior; Quantas 
16. Cite qual o número de funcionários em $P \& D$ no Brasil no ano de 2006:

\begin{tabular}{|l|l|l|l|l|l|l|}
\hline & \multicolumn{5}{|c|}{ Número de funcionários em P\&D } \\
\hline $\begin{array}{c}\text { Área de } \\
\text { Negócio }\end{array}$ & Suporte & Técnicos & Graduados & Mestre & Doutor & TOTAL \\
\hline & & & & & & \\
\hline & & & & & & \\
\hline & & & & & & \\
\hline
\end{tabular}

17. Enumere de 1 a 6 (do menos crítico ao mais crítico, respectivamente) as principais dificuldades enfrentadas pela empresa para a realização de atividades de P\&D nos quesitos abaixo?

Financiamento ( )

Legislação ( )

Tamanho e Crescimento do Mercado ( )

Ofertas de Serviços de Apoio à P\&D ( )

Segurança Jurídica ( )

Outros ( )

Especifique

BLOCO II- Caracterização do Projeto de Subvenção da Empresa

Valor do Projeto:

Título do Projeto:

18. Informações sobre o projeto

- Início do Projeto:

- Término Previsto do Projeto:

- Concluído ( )

19.10 cronograma do projeto se encontra:

- Adiantado ( )

- Atrasado ( )

- Dentro do previsto ( )

19.2 Percentual do cronograma já executado ( )

20. Como se enquadra esse projeto no programa de P\&D da empresa?

21.1 Houve parcerias para a proposição do projeto? :

- Universidades ( )

- Centros de pesquisa ( )

- Empresas ( )

- Outros ( )

21.2 Houve parcerias para a execução do projeto?

- Universidades ( )

- Centros de pesquisa ( )

- Empresas ( ) 
- Outros ( )

22. O projeto será (foi) concluído?

$\operatorname{Sim}($ )

Não ( ) Por quê?

Com ressalvas ( ) Por quê?

23. Em relação aos resultados esperados do projeto:

23.1 Os objetivos do projeto foram alcançados: $\operatorname{Sim}($ ); Não ( ); Em

Andamento com perspectivas positivas ( ); Em andamento com perspectivas negativas ( ).

23.2 Haverá Inovações: Produtos（）Processos（）Outros（）Quais?

24. O projeto gerou depósitos de patentes ou copyright ?

No Brasil ( )

No Exterior ( )

25. Houve transbordamento dos benefícios e/ou conhecimentos

adquiridos para outras atividades e pesquisas da empresa?

Sim ( ); Não ( ).

Relatar:

26. Ao longo do projeto houve alterações no objetivo proposto ?

Sim ( ); Não ( ).

Comente :

BLOCO III - Financiamento e Incentivo à P\&D

(caracterizar como a filial enxerga as políticas públicas e os incentivos em P\&D)

27. Além da Subvenção econômica, a empresa conhece outros programas de financiamentos e incentivos existentes no Brasil para atividades de P\&D?
( ) Sim
( ) Não
( ) Não se Aplica

Quais:

28. Quais outras linhas de fomento à P\&D que a empresa já utilizou?

- Lei de Inovação ( ) Sim ( ) Não

- Lei do Bem ( ) Sim ( ) Não

- Lei de Informática ( ) Sim ( ) Não

- Programas da FAPESP ( ) Sim （）Não

- Fundos Setoriais ( ) Sim ( ) Não

- Linhas do BNDES:

- Outras ( ); Quais:

29. Que ações de governo sua empresa julga serem importantes para ampliar seus investimentos em P\&D?

30. Quais as dificuldades encontradas no processo de financiamento?

31. Pretende recorrer a novos financiamentos ou linhas de apoio?

32. Outras observações a fazer em relação à subvenção econômica? 


\begin{tabular}{|c|c|c|}
\hline \multicolumn{3}{|c|}{ Milhões de Reais) - situação das entrevistas. } \\
\hline \multirow[t]{2}{*}{$1^{\circ}$} & EMBRAER - EMPRESA BRASILEIRA DE AERONÁUTICA S/A & $59.282 .223,29$ \\
\hline & Não recebeu & \\
\hline \multirow[t]{2}{*}{$2^{\circ}$} & CRISTÁLIA PRODUTOS QUÍMICOS FARMACÊUTICOS LTDA. & $31.042 .071,14$ \\
\hline & Roberto Debom Moreira & \\
\hline \multirow[t]{2}{*}{$3^{\circ}$} & VALE SOLUÇÕES EM ENERGIA S.A. - VSE & $30.229 .965,33$ \\
\hline & Não recebeu & \\
\hline \multirow[t]{2}{*}{$4^{\circ}$} & CANAVIALIS S.A. & $26.253 .604,18$ \\
\hline & Não recebeu & \\
\hline \multirow[t]{2}{*}{$5^{\circ}$} & AVIBRAS DIVISÃO AÉREA E NAVAL S/A & $18.885 .695,00$ \\
\hline & Renato Bastos Tovar & \\
\hline \multirow[t]{2}{*}{$6^{\circ}$} & VICPETRO S.A & $18.542 .600,00$ \\
\hline & Pedro Burzelli & \\
\hline \multirow[t]{2}{*}{$7^{\circ}$} & ALELLYX S.A & 18.185.014,38 \\
\hline & Não recebeu & \\
\hline \multirow[t]{2}{*}{$8^{\circ}$} & GRADIENTE ELETRÔNICA S.A. & $9.720 .832,00$ \\
\hline & Não recebeu & \\
\hline \multirow[t]{2}{*}{$9^{\circ}$} & MARCOPOLO S/A & $8.941 .744,00$ \\
\hline & Entrevista respondida por meio eletrônico & \\
\hline \multirow[t]{2}{*}{$10^{\circ}$} & $\begin{array}{l}\text { IMCOPA IMPORTAÇÃO EXPORTAÇÃO E INDUSTRIA DE } \\
\text { ÓLEOS S.A. }\end{array}$ & $8.011 .578,00$ \\
\hline & Paula Siqueira & \\
\hline \multirow[t]{2}{*}{$11^{\circ}$} & MECTRON - ENGENHARIA INDÚSTRIA E COMÉRCIO S.A & $7.927 .743,57$ \\
\hline & Hermes Nilton Macau & \\
\hline \multirow[t]{2}{*}{$12^{\circ}$} & TECSIS - TECNOLOGIA E SISTEMAS AVANÇADOS LTDA & $7.899 .140,00$ \\
\hline & Rodolfo Pedroso Vital & \\
\hline \multirow[t]{2}{*}{$13^{\circ}$} & MARISA GURJÃO PINHEIRO & $7.856 .000,00$ \\
\hline & Não recebeu & \\
\hline \multirow[t]{2}{*}{$14^{\circ}$} & VICUNHA S/A ( VICUNHA TÊXTIL) & $7.822 .824,40$ \\
\hline & Pedro Cesar Gomes & \\
\hline $15^{\circ}$ & OPTO ELETRÔNICA S.A. & 7.374.996,24 \\
\hline & Mario Antonio Stefani & \\
\hline
\end{tabular}

